H.

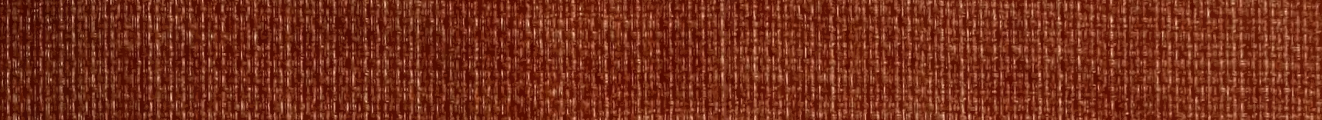
(2)

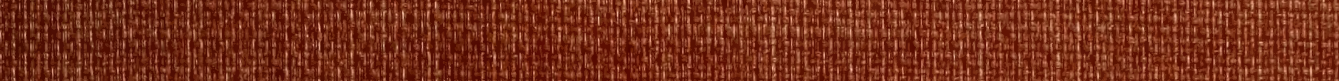
150.

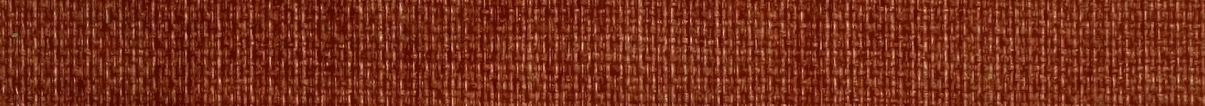

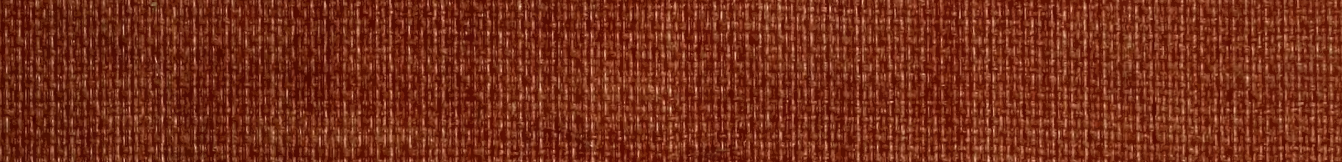
(19)

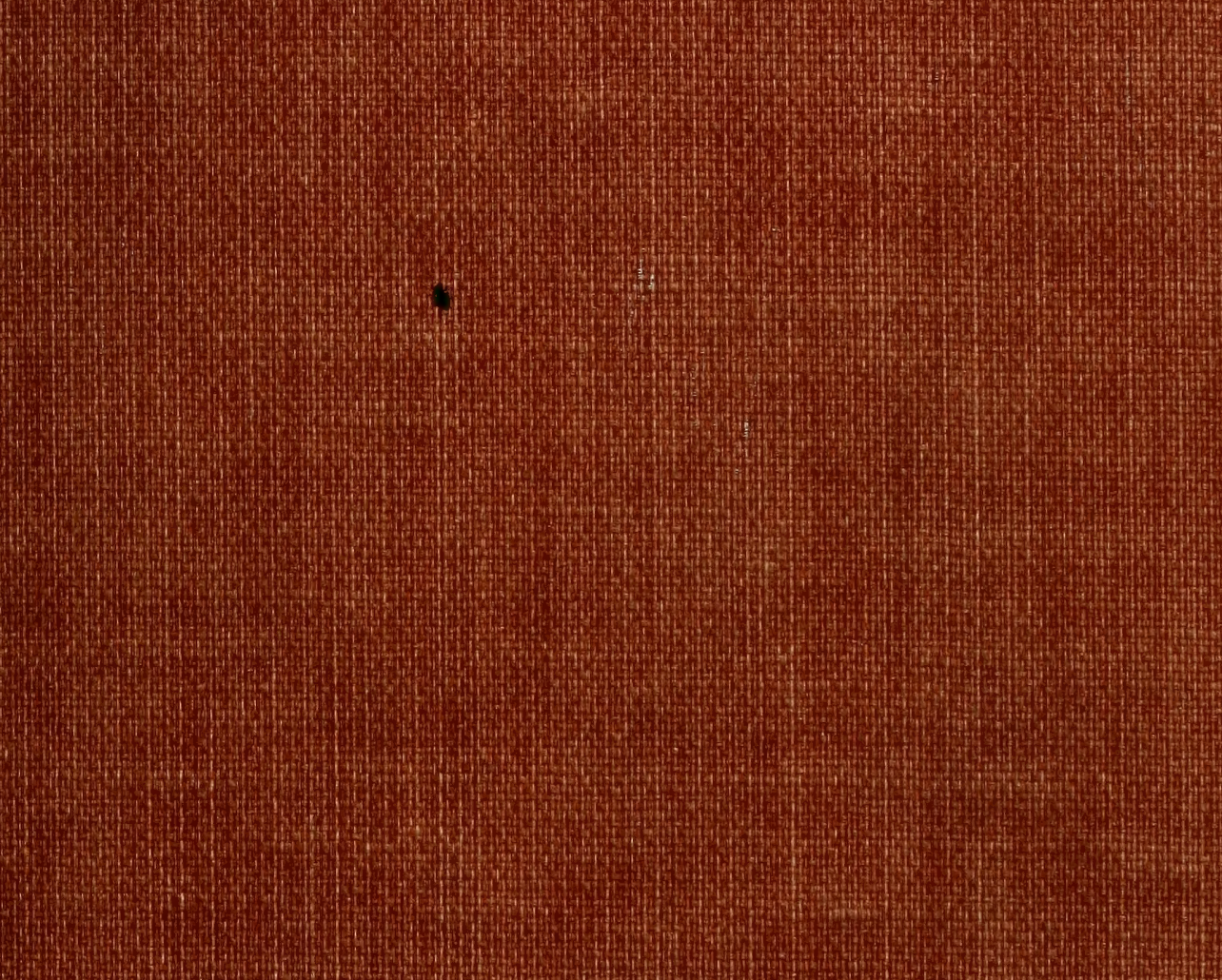

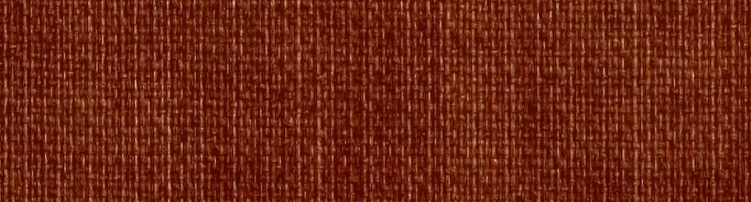

+5

政

-5

H.

in 


\section{Enet Mror Libray}

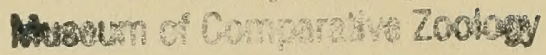

Harked Lowaray

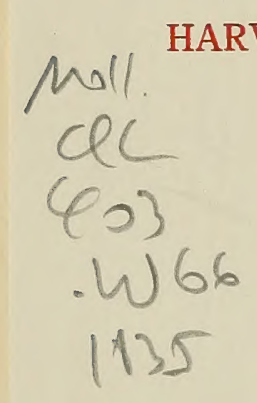

LIBRARY

OF THE

DEPARTMENT OF MOLLUSKS

IN THE

Museum of Comparative Zoology

Gift of:

Fichard W. Foster 


\section{Maräct Library}

Gift of Michard W. Foster 1944

\section{HARVARD UNIVERSITY}

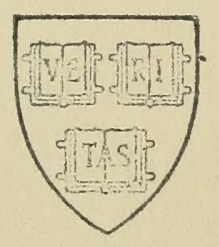

\section{LIDRARY}

OF THE

DEPARTMENT OF MOLLUSKS

IN THE

Museum of Comparative Zoology

Gift of:

Richure Vi. Foster 



\title{
GENERAL CONCHOLOGY;
}

OR,

\author{
A DESCRIPTION
}

OF

\section{SHELLS,}

ARRANGED ACCORDING TO THE LINNEAN SYSTEM,

$$
\text { AND }
$$

Illustrated with Sixty Plates, containing 260 Figures of Univalves and Bivalves.

BY

W. W00D, F.R.S. \& L.S.

L O NDON:

PRINTED FOR JOHN BOOTH, DUKE STREET, PORTLAND PLACE. 



\section{ADVERTISEMENT.}

Natural History, such as it is considered by systematic authors, consists principally in the knowledge of species. The Botanist becomes acquainted with the different plants, and learns to arrange them by the particular characters which belong to each individual, and by the general relation which they bear to each other. The Ornithologist, the Entomologist, and the Conchologist, by the same means distinguish birds, insects, and shells. To make this knowledge attainable, that is, to enable the Naturalist from certain particular characters to distinguish immediately one subject in nature from another, is the only purpose of system. But in nature there is something more to be discovered, something more to be desired than the knowledge of the mere external form of her productions. We are taught to believe, that nothing has been formed in vain; it therefore becomes the rational Naturalist, not to confine himself to the exterior only, but to discover, as far as his ability will permit, the respective habits and faculties of the different animals, and their degrees of utility, either with reference to the general theory of nature, or to those particulars in which they may become serviceable to mankind. It must be confessed, that the superficial examination alone of the works of Nature is delightful, 
but when those works are steadily contemplated, there is a feeling superadded which makes the delight more permanent, for all of them mock the imitative power of man, and bear evidences of omniscience which no sophistry can shake, no argument can overturn.

Conchology considered in this view, requires nothing more to excite curiosity or command attention. Its varied subjects exhibit a richness of colouring and diversity of form, not to be exceeded by any other class of natural beings; and its numerous productions, when collected with care and arranged in order, will afford the possessor a gratifying source of instruction and amusement.

It will be proper, before we proceed to the immediate object of the work, to notice that the arrangement which the author has pursued, in order to render it acceptable to the scientific Naturalist, is strictly Linnæan. All systems built upon artificial principles must be liable to objections, and such is the system of Linnæus. But as, notwithstanding the attempts which have been made to form a more perfect arrangement, the structure raised by the great Swedish Naturalist still remains unshaken, we cannot do better than adhere to those rules which his authority has sanctioned.

The plates which accompany this work, will be accurately drawn and engraved from specimens only, and the possessors of the shells, to whose liberality the author has been indebted for their use, will be acknowledged at the head of their respective 
specifications: where no such acknowledgment appears with the reference to a figure, it may be presumed that the subject belongs to the author. It is designed, in the course of the publication, to describe every species of shell, and to figure all the most prominent, as well as those striking varieties which are liable to mislead the Naturalist, and create confusion by causing an improper multiplication of species

The errors of Gmelin which are numerous, and his synonyms which are often wrong, have been noticed and corrected. No transcriptions whatever have been made upon trust, but all references very carefully examined, and many of doubtful authority rejected. This part of his plan it would have been vain for the author to have attempted without particular aid, without a library of reference fully adequate to the purpose intended to be fulfilled. That such a library exists, and that such aid is most liberally afforded to those who desire it, no one need be ignorant who has heard the name of Sir Joseph Banks.

There have not been wanting those who have objected against collecting of shells as a trifling and useless employment ; but let them recollect that all utility is comparative, and that no desire after what is curious, unless it be suffered to absorb more important considerations, ought to be suppressed. A great part of our time is but too apt to be wasted, and therefore any pursuit is commendable that furnishes a rational amusement for that portion of 
life, which might otherwise be lost in idleness. Nature teems throughout with interesting objects, each of which, when properly considered, may become the subject of admiration; and all may feel an equal interest in their several occupations, from the philosopher who contemplates myriads of animals in a drop of water, to him, who disclaiming the minuter parts of the creation, spends his nights in watching the revolutions of the celestial orbs, or penetrating the etherial space to worlds beyond our own.

Titchfield Street, April, 1814. 


\section{INTRODUCTION.}

Of the Animals inhabiting Shells.

Th E animals inhabiting shells, belong to the Class Mollusca, and are divided into two orders; viz. those with an appendage, or foot, proper for creeping, and a distinct head, Gastéropodes; and those which have no foot, or one that is not calculated for creeping, and are without a head, Acéphales. The animals of both divisions are quite soft, that is, without bones or any internal hardness, and form a considerable portion of Lamarck's work, entitled Animaux sans vertèbres.

The Gastéropodes, or those with the climbing or creeping foot, are confined to univalve shells; while those without a head, called Acéphales, chiefly inhabit the bivalves. As to the animals of multivalve shells, some are headless, and others have a peculiar organization, (such as the Lepades) which is independent of the rest.

The head, of such of these animals as have one, VOL. I. 
is nothing but a round and fleshy eminence, placed on the anterior and upper part of the body, and generally armed with two, or four, moveable horns, or tentacula. These horns differ in their structure. In the common snail, there are four, two large and two small: they are hollow tubes, with eyes at the end, and are capable of being extended, or drawn in, at the pleasure of the animal. The Fossar of Adanson, Helix ambigua, has but two, which are solid, and immoveable, and the eyes are situated at the anterior base of each. The position of the eyes in the animal is, consequently, subject to variation ; we find some that project, others that are sunk; some that are large, and others that are small.

The mouth is very small in the animals of the univalve shells; it is generally a little groove, varying in its form and direction. In the snails, it is furnished with minute substances, which may be called teeth, and which are useful to them in feeding; and, in the animals of the genus Murex, it is a small oval hole, fiom which issues a long retractile trunk, terminated by a sucker, armed with short feelers. It is with this trunk that they seize and kill such of the smaller animals as are destined for their prey.

- The great muscle, or foot, which extends under the neck, and part of the breast, of the animals of univalve shells, is flat beneath, convex above, and every moment changing its shape and direction. It 
often carries a calcareous, or cartilaginous operculum, or lid, of a very variable shape, which seems to close the opening of the shell, when the animal retires.

The mantle is a muscular membrane, generally thin, which lines the interior walls of the shell, and envelopes the body, except the head and foot. In some cases it lines not only the inside, but also the outside of the shell, and in many it is prolonged in a tubular form, which projects considerably before, and assists the animal either in its movements, or in fixing to solid bodies. 'The mantle has one or two holes, differently situated, one for the absorption of air, the other for the passage of the excrements.

The Gastéropodes have a brain situated in the upper part of the head, from which proceed two cords, that unite and form a ganglion above the gullet. It is from the brain and this ganglion, that all the nerves proceed, which give sensation to the animal, and life to all its parts. They have also a heart, placed in the upper part of the body, and composed of a single ventricle. Two vessels communicate with it, one from the liver and other viscera, and the other from what Cuvier calls the lungs. The liver is very large, and divided into four lobes, three anterior, and the fourth of a spiral shape, which entirely fills the posterior part of the shell. The organs of nutrition are the stomach and the great and small intestine, all of them different parts 
of the same canal. After the mouth comes the pharynx, which is provided with valves, a singular conformation, to prevent the return of the aliment. 'The stomach is placed below the breast, and after that the intestine, which lessens as it proceeds, till it turns back upon itself, enters between the lobes of the liver, and opens, for the passage of the excrement, from the cavity of the chest.

The Acéphales, which are very differently organized, may be divided into two sections, each of which should be considered separately.

The first comprehends only the animals that move from place to place; and these, instead of a head, have two tubes, or siphons, sometimes united, sometimes separate, but always susceptible of being lengthened, or contracted, at pleasure. The largest of these tubes absorbs water and animalcula, and is called the mouth; the other, which rejects water and the excrements, cannot be mistaken for the anus. Their opening is generally ciliated, or fringed. The mantle lines the interior of the shell, and envelopes the body more or less, according to the species. Between the mantle and the body, wc find the tracheæ, which in these animals answer the purpose of lungs, and are the same to them as gills are to fishes. 'They are generally composed of four membranous leaves, attached to the body of the animal, and formed by a tissue of little longitudinal 
trunks, very closely united by others, which run in a transverse direction: these trunks have a hole at top, by which the water enters, and their ends are generally fringed. We have a very familiar example of these tracheæ in the beard of an oyster.

Beneath the trunks is seen a thick muscle, which is capable of being lengthened, and moved on all sides, or may be entirely shut within the shell. This is called the foot; but although it, in part, fulfils the functions of the same organ, in the animal of univalve shells, it bears no resemblance, except in being flat beneath. It is used by the animals to make a groove, deep enough to sustain its shell, in a vertical position, when it moves from one place to another, or to dig beneath the sand, or mud, when it wishes either to avoid the cold, or hide itself from its enemies.

The Acéphales of the second section have no siphons ; both their openings are simple holes, concealed under the doublings of the mouth and the trachea. Part of these animals have an organization similar to those of the preceding section; but some have a foot, while others have none.

Those without siphons, which have a foot, are either like the animals of the first section, that is, can form a groove, and move in the sand, or are solely designed to spin the thread, or byssus, with which 
nature has provided them, for the purpose of fixing their shells to rocks, or stones. 'The foot in these animals is always smaller, more pointed, and channelled by a longitudinal groove, intended to give shape to the thread, which first exudes, like gum, from the end of it. The Muscle and the Pinna are examples of this division. They are capable of locomotion ; but unless torn from their hold, by a superior force, they generally remain in the place where they first established themselves.

'The Acéphales without siphons, which have no foot, are fixed for their lives, by a calcareous cement. These, such as oysters, are of the lowest order of animated beings ; their organization is extremely simple; they have merely two holes for the mouth, \&c. four pulmonary leaflets, called the beard, and a mantle.

All the animals of Bivalves are fixed to their shells by a muscle, which is attached to the hinge, and by one, two, or more, fixed to the interior of the valves, in the places which conchologists call muscular impressions. These last muscles are principally designed to close the sides of the shell; that they do it effectually, all will acknowledge, who are used to the opening of oysters. The force with which they close their shells varics, of course, in proportion to the strength of their muscles. Poli, who tried several experiments on the muscular 
strength of shell fish, found, by means of a machine made for the purpose, that a weight of twenty-five pounds would force the valves of an Arca barbata, while it required fifty-nine pounds to open a Spondylus.

Among the animals inhabiting shells, some are oviparous, and others viviparous. Of the oviparous, some are isolated, and covered with a crust, like the eggs of birds, such as the terrestrial snails; others are included in a gelly, which unites them together, such as the aquatic snails; while others, again, as the whelks, deposit their eggs in membranous bags, of an oval, or spherical shape, generally grouped in bunches, like grapes, of a pale straw colour, with each a small hole in the side.

The young of Bivalves are contained between the tracheæ of the parent, that is to say, the leaves of their beard. They are covered with shell, even before they leave the body of the mother. The young of shells which are designed to move from place to place leave their eggs very neatly formed; but those which are to remain fixed during their lives, are at first covered with a mucilaginous matter, which sticks to whatever it touches, and thus forms the first adhesion, which is afterwards strengthened by the stony juice, secreted from the body of the animal. 
On the Formation of the Shell, in Testaceous Animals.

IF we were to be asked why one slug goes naked, while another is provided with a habitation; why two animals of the same manners, the same appetites, the same internal, and nearly the same external conformation, should be so differently dealt with, it would be difficult to find a satisfactory answer. The powers of nature are generally sufficient for the purposes she intends to fulfil. Now and then there appears to be something wanting in her operations; but when we tax her with deficiencies, it is still possible that she may be right, and we be wrong. In the present instance, there seems to be either profusion in one case, or parsimony in the other, since the common slug has merely the rudiments of a shell ; it can lay only the first stone, while the garden snail can build a house.

It is not to our purpose to consider who first discovered the thin testaceous plate on the back of the slug; it is enough to be assured that it exists, and to describe it accordingly. There is an oval, warty substance, extending from the neck, partly down the back of the slug, called the lesser mantle, or 
shield; in the thickness of this mantle there is a cavity which contains the shell. The under part of the shell is separated from the heart of the animal, by a thin membrane; above, it is covered by the skin of the mantle. It lies in its cavity perfectly detached, without any organic union, and is a single deposition of carbonate of lime, connected by gluten, exactly like any other shell. It is to be found in the small slugs, as well as the large; but in the great brown slug, it is half an inch long, and a quarter broad. There is no doubt that the calcareous matter is secreted from the lower part of the cavity, and that, the operation being continued at different times, the shell accumulates as the animal advances in growth. The different accessions of shell may be distinguished by the striæ seen in its substance.

We have here a very simple process, confined to the mere secretion of calcareous matter, without any mechanical contrivance whatever. It is not so with the garden snail; her powers are by no means so limited. She can construct a habitation which unites two distinguishing properties, strength and lightness. It is a well turned arch, that can defend her body from all common accidents, and be transferred, without inconvenience, wherever she pleases. The snail is oviparous, and the young leave the egg completely covered with a very thin transparent

$$
\text { VOL. I. }
$$


shell, of one spire. The animal, shell and all, is not at that time larger than a split pea; therefore much remains to be done, before it acquires its full growth and solidity. The inhabitants of univalve shells, such as the snail, periwinkle, whelk, \&c. constantly enlarge their apartment, by adding fresh accessions of materials to the mouth. The whole body indeed is covered with pores, through which a viscid liquor exudes; but the part which contributes principally to the increase of the shell, is a fleshy collar above the neck. This in the snail is very visible; and on opening its substance, a glandular tissue is seen, of a whitish colour, and studded with little semi-transparent points. These points are noticed by Cuvier, who adds that, upon irritating the snail, it will throw out, from all parts of its collar, a white liquid, visibly formed of calcareous molecules, suspended in a viscous fluid. We have here pretty evident marks of design; a storehouse for the preparation of materials is placed where a storehouse only could have been of use. The rest of the body is confined by shell: the animal, if it increases at all, must increase by the mouth; and if unprovided with the means of enlarging its room by the aperture, it would become a long naked snail, with merely the shell it was born with on its tail. But we have seen what provision nature has made in the snail against nakcdness. As the body protrudes, the collar secretes, and lime and glue, which 
are thrown out in abundance, thicken into a consistence round the mouth of the shell. Thus, as the animal increases in bulk, it continues to produce fresh materials, and enlarges its house till it has acquired its full growth.

The same process of the animal economy which enables the snail to build a house, will also serve to keep it in repair. If we break out a piece of the shell, without wounding the snail, the skin beneath will soon become covered with a viscid exudation, which thickens and congeals by degrees. Twentyfour hours after the operation, the repair will be fairly begun, a thin layer will be visible, and this will continue to thicken, till, in ten or twelve days, the new piece will be nearly as thick and strong, as the rest of the shell. A similar matter is transuded also from the collar of the snail, when she wishes to close the mouth of her shell against the approach of winter. This thin calcareous operculum, or lid, is very different from the permanent lids of several other shells. It is not fixed to the head of the animal, but is perfectly free from any part of the body, though strongly adhering to the mouth of the shell. It is easy to prove its shelly nature; for, when plunged into diluted muriatic acid, its calcareous parts dissolve and leave merely a gelatinous tissue behind. 
Having traced the formation of the shell in a land animal, let us now take a subject from the sea, and we shall find that the same end is produced, in a somewhat different manner. Conchologists are indebted to a French naturalist, M. Bruguiere, for some curious observations on the formation of the shell of the cowry, \&c. which the Author begs leave to repeat from what he has already published in the second Volume of Zoography. The inhabitant of the cowry, indepcndent of the organs which are common to animals of other univalve shells, has two membranaceous appendages, or wings, placed on the sides of the body, with which the creature can completely cover itself. These two wings contribute greatly, together with the edge of the neck, or collar, of the animal, towards the formation of the shell, since they furnish the ordinary exterior layers of enamel, upon which we may perceive the marks of the laminæ, or successive coats, whereof all shells are composed. The shape of the exterior layers is different from those situated beneath, which may be considered as a smooth, shining substance, that the animal goes over once, while it is forming its shell, in order to give it the necessary solidity. It is from the body of the animal, or from the edge of its collar, that the inferior part of the shell is formed, or rather the testaceous mould. This mould is generally thin, and very brittle: it is striated longitudinally; and, as its origin is not different from 
that of other shells, it is not surprising that we find proofs of the formation of the regular projections, which the extremities of the layers leave by the side of each other. The colours of the mould are different from those of the exterior layers, and it frequently shows the transversal bands with which it is marked, while the enamel is adorned with spots or stains, because some parts of the body are supposed to furnish this composition, which is secreted from certain moist glands, of a different kind from those of the wings.

Thus we remark two distinct operations in the formation of the cowry. The first is that which produces the part of the shell called the mould, and is the result of a secretion from the body of the animal ; the second, the formation of the shining enamel. The cowries are thin and transparent, in the first stages of their growth, but at length acquire solidity, by means of the external layers, which the animal applies after the mouth is not only formed, but considerably contracted, and furnished with the rudiments of teeth. The last coats proceed, as we have already observed, from a transudation from the wings of the animal, and leave upon the convex surface of the shell the marks of the manner in which they are formed. This is by a longitudinal line, which divides them into two unequal parts. This line, made by the junction of the wings of the ani- 
mal, plainly indicates, by the faintness of the tint, that the colouring juice was wanting in that part. It is a simple straight line, when the edges of the wings are of the same configuration, but passes in a sinuous, or waving, direction, as in the Cyprcea Mappa, when the same edges are fringed, or irregularly cut in their contours.

There is a singular fact, noticed by Bruguiere, respecting the animal inhabitants of these shells. They can quit their apartment at pleasure, and construct a new one, whenever they find it convenient. This, however, is never done but from necessity. During the time the animal is completing its shell, it increases in size, till at length it grows too large for its habitation, which, when finished, remains permanent. Thus straightened for room, it is obliged to quit its old dwelling, and build a new one of larger dimensions, and better proportioned to the increased size of its body. We are at a loss to say how this operation is performed; but it is probably a matter of no great labour, since the body of the animal is of a consistence between tendinous and mucilaginous, of course not making any great resistance to its passage through the mouth of the shell; for the foot and the two wings, which compose by far the largest part of the body, slip out in a moment, with the greatest ease. This separation of the animal from its shell is not difficult to con- 
ceive, when we consider how readily the lobster quits its crustaceous covering, and the crab gets rid of its claw.

When the cowry has completely abandoned its shell, it is quite naked, and exposed to the immediate influence of the sea. From the irritation occasioned by the salt water, or from some other cause of which we are ignorant, the hinder parts of the body again begin to furnish the testaceous matter, which is afterwards condensed upon the surface. This secretion is continued till, at length, the shell appears of the consistence of paper, and the mouth, which at this period is very wide, soon afterwards contracts to its proper shape. The wings of the animal, folded upon its convex surface, thicken and form the teeth, which are seen on the edge of the mouth, and which are deposited with the enamel that adorns the external part of the shell. In this manner is produced the opaque and highly polished surface, which is so eminently beautiful in the full-grown cowry, and which, by the colour of its spots, or stains, contributes greatly towards distinguishing the different species of the genus.

Bivalve shells, such as Muscles, Oysters, \&c., increase by adding to their whole circumference, or rather to all the edge, except the hinge; and every - experiment that has been made upon the subject, 
tends to prove that shells increase by a perfect juxtaposition of calcareous beds, united by a viscous cement, and formed successively from the interior of the shell, as the animal advances in growth. These beds may be made very evident, by heating an oyster-shell in the fire, without totally destroying its organization. It may then be easily separated into the different beds (or leaves) which form its substance, and the mechanism of the shell completely exposed. 
On the Colours of Shells, and the Formation of their Streaks and Spots.

The first thing which presents itself to the Conchologist is the colours of shells, which may justly be admired, both for their beauty and variety. Nature seems here to have diversified her operations, in every way possible; some are distinctly spotted, others streaked; in some the bands are uninterrupted, in others they are broken into parts, so as to bear a slight resemblance to the notes of musick. Again we meet with shells, where the tints are partly distinct, and partly melted together, or formed, as it were, into clouds. What is the occasion of all this diversity, and how is it produced?

When a hole is made in a shell, at about midway between the summit and the mouth, the new piece which the animal supplies is generally of a whitish colour, and often very different, in appearance, from the rest of the shell ; whence we may conclude that it is not made precisely in the same manner. To clear up this difficulty, it will be necessary to ascertain how this regular variety of colour is produced. We shall take, for an example, the 
variegated snail (Helix nemoralis). It is a common inhabitant of our woods, and gardens, and may therefore be easily brought forward as an evidence at any time. The ground of this shell is white, citron, or yellow, or of an intermediate colour. It is marked with streaks, or bands, which proceed from the apex to the mouth of the shell, and are either black, brown, or red. They vary in number; some shells have but one, others have four, and some are ornamented with five or six bands.

We have already observed, as a position which does not admit of a doubt, that all univalve shells enlarge by the mouth, in consequence of a secretion, emitted for that purpose, from the collar of the animal. Reaumur reckons it sufficient for this collar to be composed of glands filtering different humours, to form a shell of different colours. If, for example, two or three glands secrete a black, or brown humour, and these glands, which Reaumur calls filtres, are parallel to each other, while the rest of the collar emits only a uniform citron tint, it follows that the ground of the shell should be straw colour, with parallel bands of black or brown, approaching or receding from each other, in proportion as the space between the glands is greater or less.

If we could bring no proof of the above con- 
jecture respecting the variegated snail, (and what is said of that will apply to every other); if we could perceive nothing similar to the filtres mentioned by Reaumur, still the theory would furnish so probable an explanation of the variety of colours in shells, as to leave us well satisfied with the conception. But fortunately they discover themselves, and add so strong a degree of evidence to Reaumur's reasoning, that the matter is placed beyond a doubt. The body of the variegated helix, when deprived of its shell, appears of a white colour, except the collar and the parts closely connected with it, where we perceive a yellowish tint, and a number of black, or brown streaks, equal to the bands on the shell. Here we come immediately at the secret; the interior of the collar is the laboratory where the colours are prepared; the surface is the palette, from which the painter lays them on as his work proceeds. Thus the individuals that have one black ray on the shell, have but one black spot on the collar; those which have four black bands on the shell, have also four corresponding marks on the collar, and so on with the rest. These rays are placed immediately under those of the shell; they begin at about the twelfth part of an inch from the extremity of the collar, which is, itself, commonly edged with black all round, and therefore we for the most part find the lip of the shell of that colour. 
With such evidence, there is no room to doubt the real existence of the pores mentioned by Reaumur; but, lest it should be supposed that these pores do not perform the functions ascribed to them, let us see whether an experiment will not confirm the reasoning. If a portion of the shell be removed opposite the black rays, and the new piece become black; if another portion be removed between the rays, and this be renewed of a colour different from the bands, it must be allowed that these parts perform the office ascribed to them by Reaumur. Now this is exactly the fact : the new shell which is formed on the collar, opposite the brown, or black rays, is itself brown or black ; that which is formed between the rays, is white, or citron; and that which is renewed on other parts of the body will be white. The same thing happens in all other shells, marine, fresh water, or terrestrial, that are remarkable for their colours. We have not indeed experiments to illustrate every case; but what has been done is fully sufficient to warrant the conjecture, that the same phænomenon will be extended to all species of shells.

We are not, however to conclude, from what has been said of the formation of the rays, which ornament certain species, that it is a necessary consequence that all shells should be streaked! On the contrary, we find the surface of some of an uniform 
colour, and others marked with numerous spots, often of an irregular shape, and separated from each other at unequal intervals. This is the case (among other examples) with the black tiger cone (Conus marmorets, Linn.) In this, as well as in the helix, however, the spots are formed by the collar, and the black pigment secreted at intervals, so as to form irregular stains, instead of uninterrupted bands.

It must be observed, that the interior layer of the shell, or that which covers the body of the animal, independent of its collar, ought to be white, since the secretion, as we have noticed already, is generally colourless. It is sometimes, however, otherwise; the body of the animal will exude a coloured liquor, and then the interior of the shell will be stained accordingly; but the tint will be uniform, and never varied like the exterior. To make the different operations of the animal perfectly apparent, let the outer coat of a shell be filed off, and the layers beneath, which have been furnished by the body, will be uniformly white, or tinted; while the exterior, which belongs exclusively to the collar, will be variegated.

It will here be necessary to make some further observations on the growth of shells, in order to account for the change of colour which we sometimes perceive in the bands of univalves. The different 
stages of increase may be pretty readily discovered in the majority of shells, they being, for the most part, marked on their convexity with little eminences, parallel to each other, of different degrees of strength, giving the surface a fibrous appearance. These eminences, which are called stric, follow the contour of bivalve shells, and run in a spiral direction in the univalves. It will be observed, upon examining the different species, that they, for the most part, have some of these eminences particularly distinct, and distant from each other. These denote the different times when the shell was interrupted in its growth, and bear some analogy to the nodes observable in the shooting of trees.

Another circumstance, which distinctly marks the place where the growth has recommenced, is a striking change of colour in the bands which diversify some of the univalve shells. In these parts the bands are generally much lighter, and sometimes so faint as scarcely to be perceived, till they have proceeded further on the spire. This is very evident in the exotic snail (Helix pomatia), where a strong line of separation may be perceived from the umbilicus across the shell. It will not be diffcult to account for this change, if we consider that, during the inactive state of the animal, the colouring matter contained in the collar is exhausted on the last formed portion of shell, and that it will 
not be again secreted, in sufficient quantity, till after the snail has had time to recruit its strength by food.

What has been said, it is presumed, will be sufficient to explain the different phænomena, which the colours of shells in general present; but there exist some genera, such as Voluta, and Cyprcea, which are painted by a process with which Reaumur was unacquainted. Their colours are disposed on two parallel surfaces, the exterior of which is produced by a particular organization of their animals, and is the result of an operation described by M. Bruguiere, and noticed in the preceding section.

The shell of the cowry receives its colour from the pores of the animal at two distinct periods, and by different ways. In the first place, that part of the shell is formed, which is immediately secreted from the collar, or the body, of the animal ; this coat is of a moderate thickness, much inferior in strength to what it acquires in the sequel. In this primary operation, there is nothing peculiar from what takes place in other shells; but above this coat, on the convexity of the shell, there is formed a second, which covers the first entirely with a compact substance, in some places very thick, and generally stained with different colours. The organs which deposit this second bed are two soft membranaceous wings, which, issuing from the mouth of the shell, 
are reflected back on its convexity, and cover it so completely, that not an atom of the shell appears.

These two wings (which are independent of the collar of the animal) are covered with glands containing colouring liquors peculiar to themselves; and it is their upper surface, or that which is laid against the convexity of the shell, that alone furnishes the secretion. Whence it follows, that these wings deposit new layers of testaceous matter, differently coloured from those beneath, and diversified with spots, either entire, round, or zigzag. Their variety of colour is very great; they are sometimes white on a brown ground, or tawny on a yellow ground, or yellowish on a tawny ground. Sometimes we meet with lines, instead of spots, strait, curved, or reticulated; of different shades, on grounds of various colours; and occasionally the surface is covered with points (or dots), disposed in every direction.

We have observed, while speaking of the variegated helix, that its shell was subject to remarkable varieties of colour, depending on the different form and arrangement of the secreting organs. The changes which these organs undergo, and every thing that relates to their oconomy, will apply equally to all the marine, fresh water, and land snails, that exist in nature. But to the causes already de- 
tailed, it will be proper to add another, which, Bruguiere alledges, has not only a powerful influence on the brilliancy of their colours, but on the diversity of their tints, and which is wholly independent of the physical structure of the animal. This cause, though at first it appears too far removed to produce such marked effects, is no other than the influence of light, combined, perhaps, with that of heat.

Two individuals, says Bruguiere, of the same species, one found either in the northern ocean, or the Mediterranean, and the other in the seas of hot climates, present different tints, and always a vivacity of colour, decidedly in favour of the specimen from the torrid zone. Their shells, though of a similar shape, constantly differ in their colours, whence originate all those varieties, which some conchologists have considered as distinct species, although it is very probable, nay almost certain, that these differences depend merely on the action of climate, of nourishment, or of particular circumstances, not as yet sufficiently understood.

The difference of temperature, where these individuals are supposed to live, would seem at first to be the principal cause of their difference of colour, if we were not certain that shells naturally coloured, either in the seas of the torrid zone, or those of the temperate, acquire more or less intensity in their

VOL. I. 
tints, and sometimes a different disposition in their symmetry, according to the degree of depth at which they are situated in the sea. Bruguiere is led to believe, that on this circumstance alone depends the weakness of the tints with which a shell is variegated; and he even supposes that their total privation is owing to the shell inhabiting a depth too great for the due admission of light and heat. To strengthen his assertion, he observes, that the bivalve shells, which fix themselves to the rocks, such as the oysters, and spondyles, have generally their upper valve deeply coloured, while the lower valve, attached to the rock, is almost always white. The oysters and spondyles are not the only shells that show a constant difference in the colour of their valves; the same effect happens to all that live fixed to any solid body. The pectens also, though painted with various colours above, are white beneath. The pholades and ship-borers, which bury themselves in woods and limestone, are also colourless. One position of this theory will not be disputed, since there is no doubt that bodies wholly deprived of light will be without colour; but it still remains to be proved, whether the tints of shells will be much injured by a partial privation. 
Of the Tubercles, Spines, \&c. which are found on Shells.

IT is sufficiently evident, that any pliable substance will assume the form of the body on which it is moulded, and that, consequently, if the animal inhabitant of a shell has any. muscular inequalities, the same will be observable in its exterior conformation. This point being allowed, there is no longer any difficulty in accounting for the warts, and spiny processes, on the backs of shells, which may be considered as so many testaceous incrustations, deposited by corresponding fleshy tubercles. These excrescences may often be observed in the first turn of a spiral shell, and they will be found, more or less, in every succeeding spire which the animal adds to its habitation. This is particularly evident in the Murex Mancinella, which is fiequently so covered with tubercles, as to be much disfigured in its shape. The long spines, which appear on some species of the above genus, have the same origin as the shapeless knobs just mentioned. They have their interior moulds upon which they are formed, and are either hollow, partly solid, or perfectly closed, in proportion as the animal excres- 
cence continues in vigour, is partly absorbed, of totally wasted. In this case, the hollow part will be supplied with testaceous matter, secreted from the body of the animal, till it is filled up even with the interior surface of the shell. In the Strombus genus, where the lip of the shell is often lengthened (or divided) into a certain number of channels, or fingers, the same thing takes place; each channel is occupied by a corresponding portion of the animal, endowed with the same secreting faculty as the other parts of the body, and consequently capable of adding to its groove, whenever it finds occasion. The Strombus Lambis, or spider shell, is a remarkable instance of this digitated appearance. In the genus Murex, the mouth of the shell is lengthened (more or less) into a beak or canal, containing a cylindrical organ, capable of contraction and extension. This, according to some authors, is used by the animal as a feeler, and occasionally as a cable, to moor the shell to some solid body.

The furrows, or ridges, met with in other shells, while the whole of their interior surface is polished, will be readily explained, when we consider the formation of the animal. These furrows occur particularly in the bivalve shells, such as the scallops (Pecten), the cockles (Cardium), \&c.; and when-

- ever we meet with this peculiar organization, it will be found that the animal partakes of the same conformation, the extremity or fleshy contour being 
channelled, so that the interior of the shell is also impressed in the same manner for some distance from its edge. When the ridges are once formed on the outside, they remain permanent ; the animal has no power to alter them. It is not so within, for we find that the posterior part is smooth, the furrows previously formed by the channelled extremity being worn away, or filled up by the body of the animal. 


\section{Of the Habitation of Shells.}

Shells may be divided, with reference to the places they inhabit, into terrestrial, river, and marine, that is, into those living on land, in fresh water, or in the sea. It is the opinion of Bruguiere, that we know less of land than of sea shells. He affirms, that the shells of the Mediterranean sea are nearly the same, from the Straits of Gibraltar to the island of Sicily; while the land shells of Languedoc often differ from those of Provence, of Dauphiny, of Piedmont, and of different parts of Italy. We find shells in Spain, in Corsica, in Sardinia, and in Sicily, which are not to be met with elsewhere; and if (adds Bruguiere) we may found our opinion on what has been sent from those countries, we may rest assured that the sea produces scarcely any thing new, while the unknown land shells are still very numerous. This may possibly be the case with respect to the Mediterranean; but it will not apply to many other parts of the world, as we are daily getting fresh accessions of new marine species, and, where they are not discovered, it is more for want of diligence in the search, than variety in Nature. 
Land shells are to be found in different situations; some prefer dry banks, and exposed heaths, while others live in moist places, near running water, in thick woods, or in the crevices of old walls. The smaller species are frequently found sheltered under the moss which grows at the foot of trees, and sometimes in the decayed wood. In the spring, they often retire from the heat, under great stones. In winter they must be looked for in holes of trees, in the slits of the bark, or in the fissures of rocks. But, in general, the most favourable time for the discovery of these animals is the spring; because, in that season, they rouse from the torpidity of winter, and go forth with fresh vigour to seek for food.

The fresh-water shells are far less numerous than those which inhabit the land. They are found not only in rivers, and springs, but also in ponds and marshes, and even in muddy ditches. Some bury themselves to a certain depth in the sand, or the mud; while others live attached to stones at the bottom of the stream, except at times, when they leave the water to climb up the plants which grow upon its banks. The smaller species are the most difficult to procure, as, from their diminutive size, they readily escape observation. The best time to look for fresh-water shells, is from the end of spring to the middle of summer. At other seasons, they are thrown dead upon the banks, and often mixed with 
the smaller terrestrial species, which have been carried there by the rain waters. This should be particularly observed, because conchologists have sometimes, from this circumstance, confounded land shells with those that belong exclusively to the water. To avoid such errors, it will be proper for those who are not well acquainted with the subject, to collect none but what are alive, either in the water, or on the aquatic plants. On the Nymphcea, or water lily, the Hippuris, or mare's tail, the Potamogeton, or broad-leaved pond weed, the Lemna, or duck weed, and the Juncus, or rush, shells may be found in all stages of their growth, with their natural colours, and in the best state of preservation. Most of the species are apparent upon the surface of the plants; but some of the smaller kinds hide themselves within the folds of the leaves, and it is not uncommon to find a pretty little reversed shell, the Bulla fontinalis, wrapped in the leaf of the common water flag.

The third division of shells, or those that inhabit the sea, are more abundant in their species, and generally more brilliant in their colours, than either the land, or fresh-water kinds. The beauty of their tints, and the elegance and variety of their shape, have made them greatly esteemed by collectors; and, as mankind will ever be stimulated to exertion by the hopes of gain, sailors, and persons wholly unacquainted with conchology, have thought it 
worth their while to bring home what they could collect, as an object of traffick. It is principally to this cause that we owe the produce of the different shores, and receive shells from India, Amboina, Ceylon, New Holland, \&c. which would never reach England, if they were not profitable commodities.

All marine shells are not confined to the depths of the ocean, but, on the contrary, are often led, by an instinctive faculty, to fix on rocks, or bury themselves in the sands. These latter may be discovered on the smooth flat shores, while the tide is ebbing, by little bubbles of air rising from small openings in the sand. Each of these places denotes the retreat of a marine animal, and frequently of a shell, which may readily be dug out with a spade. The species of the genus Tellina, Solen, and Mya, conceal themselves in this manner, besides some kinds of the genus Buccinum, and many other smooth, univalve shells.

If the rocks that are washed by the sea are found pierced with small holes, regularly wrought, as if they had been bored with an instrument, it is a proof that they either are, or have been, inhabited by Pholades, or by the rugged muscle (Mytilus ru. gosus, Linn.) The only way to procure these, is to break into their habitations with a hammer; but, as the shells are very brittle, it will be difficult, by such means, to obtain them entire. 
Shells that remain fixed by one of their valves, such as oysters, or that occasionally attach themselves by their byssus, or threads, such as muscles, are often found in the fissures of rocks; while the limpets, the sea ears, the acorn-shells, and some other species of univalves, adhere firmly to the surface. In warm climates, where the Mangrove, and other trees, frequently grow within the influence of the tide, it is not uncommon to find their roots (and such of their branches as bend into the water) loaded with oysters, acorn-shells, and such other species as adhere to solid bodies.

On the coasts where the bottom of the water is muddy, shells are indicated, by slimy strings rising occasionally to the surface. To procure these shells a French author directs us to use a small net with fine meshes, mounted on a hoop of iron, and fixed to a pole of sufficient length. This is to be plunged to the bottom, directly under the place where the shell is supposed to lie, and, when drawn up, the mud escapes through the meshes, and leaves the shell in the net.

All that has been hitherto said applies only to shells that inhabit the banks of the sea, or at least a very little distance from its shore. There are many, on the contrary, such as the Cones, the Olives, the Cowries, the Volutes, and the larger species of 
Murex and Buccinum, that constantly live at a greater depth, and unless thrown by a storm, or other accident, upon the coast, are only to be obtained by dredging.

There is another way of procuring shells, which, from its singularity, will not readily be thought of by collectors. It is to examine the stomachs of fish, and water fowl; by which means many perfect, and some very rare shells have been found. Fabricius, in his History of Greenland, assures us, that he adopted this method with success, and that, in fish particularly, he met with species that were unknown on the northern coasts. It will be proper also to examine the bottom of the lead, when within soundings at sea, as foreign bodies sometimes adhere to it. The sailors know when they are in the mouth of the Channel, by a species of Dentalium, that adheres to the lead, in sounding, for a certain distance, and which they call the hake's tooth.

Those who reside at sea-ports, and are disposed to collect shells, should take every opportunity of examining the bottoms of ships that arrive from long voyages. It is not uncommon to find upon them different foreign bodies, and particularly acorn shells (Balani). The first specimens of the thorny acorn-shell (Lepas spinosus) were found by the French, on the keel of a Danish ship that had remained some time at $\mathrm{St}$. Helena. 
There is something singular in the strict locality of shells : one would hardly imagine that particular species, capable of locomotion, had distinct places of abode, from which they never swerve, unless forced by accident. They are also affected by difference of temperature. When Peron visited New Holland, he found, at its southern extremity, the great sea-ear, Haliotis gigantea, in full perfection. It is there found in large quantities, and is of essential service to the inhabitants of Van Dieman's Land, who derive from its flesh an abundant and wholesome nourishment. Upon moving but a short distance towards a warmer latitude, he found the shell decrease in size; and, in proportion as he proceeded, it became less and less, till, at the port of Rio Georges, it totally disappeared. This happened to other species as well as the sea-ear, whence it may be inferred, that the animal inhabitants of shells, originally of cold climates, cannot exist in the torrid zone. The contrary will also hold with respect to those of hot climates, and upon this position Peron has the following remarks :

Of all the countries which we have hitherto seen, there is not one to be compared to Timor, for the abundance and variety of its shells. The richness of its shore, in this particular, is really beyond all expression. We have collected from it more than twenty thousand shells, among which may be distinguished many hundred species; and yet, of this 
prodigious multitude of testaceous productions, there is not one like what we found, either in Van Dieman's Land, or any of the southern parts of New Holland; it is not till we approach the equatorial regions that we find any of the Timorian shells. This singular exclusion not only holds good of the species, but may also be observed among the genera: that is, among those whose numerous species seem to have been exclusively attributed to some particular part of the globe. Thus, for example, in the equatorial countries, a multitude of Cones, Olives, Cowries, \&c. collect together, which are scarcely known on the colder banks of either hemisphere. Thus while Timor, and its neighbouring islands, abound in beautiful shells, two or three small, obscure species, are all that dare to show themselves in the southern extremity of New Holland. 
On collecting, and cleaning Shells.

IT happens very frequently, that persons who collect shells for their friends, in foreign countries, though they do it with the best intention, yet, for want of a sufficient knowledge of the subject, are apt to pick up many that are either imperfect, or of little or no value, and to pack them so carelessly, that; by the time they reach England, very few of them remain entire. For the instruction of such as may not be conversant in collecting, I would recommend them always, if possible, to procure what are termed live shells, that is, with the animal in them; this is only to be done by using a drag net, or after violent storms, when live shells are often torn from the deep, and thrown upon the sea-shore. When they have been exposed for some time on the beach, they get injured by friction, and their colours fade in the sun. In this state, they are known among collectors by the name of dead shells, and are only to be taken, when better cannot be procured.

It is sometimes difficult to detach the animals, particularly of Univalves, entirely from their shells. 
This operation must be managed by first plunging them into boiling water, and, afterwards, carefully picking them out, so as (if possible) not to break the spiral part, or leave a portion behind. When this cannot be avoided, the shell should be left in cold water, till the part decays, when it may be washed out. In Bivalves, and other shells, the fish may be easily removed with a knife. After which, a string should be tied round the valves, across the shell, to keep it close till the cartilage at the hinge stiffens.

As shells are of a calcareous nature, it follows that all acids must be more or less injurious, that are made use of to clean them. Many shells are fished up so clean and perfectly polished by Nature, that they require no assistance from art. Others, on the contrary, come out of the sea slimy, and covered with extraneous substances, such as corallines, fuci, \&c. These must be cleaned with soap and water, and a hard tooth-brush, which is best adapted of any thing I know for the purpose. The extraneous coralline substances that remain on the surface of the shell, after it has been cleaned, may be removed with muriatic acid, diluted with three parts of water, being careful, at the same time, not to touch the shell with the acid.

Many shells have an outer skin, called an epidermis; this sometimes adheres very strongly, and, although scientific collectors choose to have their 
shells in a natural state, there are others who wish to see their beauties revealed. To remove this epidermis, it should be first soaked for a day or two in water, and then rubbed firmly with a hard brush, armed with finely powdered pumice-stone. It will often be difficult to remove every part of the pellicle; but, by diligently persevering, it may be done.

It is not unusual, when the colours of the shells are rather dull, to revive them with varnish. This may reasonably be allowed, since it only imitates their appearance when wet out of the sea. The best varnish for the purpose is a simple solution of gum Arabic, in water, which can be laid on with a camel-hair pencil, and easily washed off again, at any time, without injuring the shell.

Collectors are sometimes imposed upon by a trick, which was first practised in Holland, where two or more shells are sold as distinct species, which are precisely the same, except that one of them has had its external coat taken off, by grinding the shell on a wheel charged with oil and emery. Many shells by this process assume a new appearance. The common cowry becomes violet; the nautilus, which has broad tawny stripes on its sides, rubs down to a fine mother-of-pearl; and many of the limpets become so altered in their colours, that they lose all resemblance to the original shell. 
When shells are to be removed from place to place, they must be very carefully packed, or they will most certainly be injured in their passage. The best direction for this purpose, is to wrap each in a piece of silver paper, and lay them in a box, though not so close as to touch. Each layer of shells is then to be covered, completely, with a layer of bran, and this may be repeated till the box is filled. The box must then be gently moved backwards and forwards, that the bran may settle; as it is of consequence to fill it perfectly, before the lid is nailed down. It will be scarcely necessary to add, that the very heavy shells should be excluded, or that the lightest should be placed at top, and the box always kept upright. By these means; shells may be sent, with safety, to any part of the world.

VOL. T. 



\section{A \\ CHRONOLOGICAL LIST}

OF

\section{WRITERS ON SHELLS.}

For an historical account of the under-mentioned Writers, see a most excellent Paper in the Seventh Volume of the Linnean Transactions, by William George Maton, M. D.; and the Rev. Thomas Rackett, M.A.

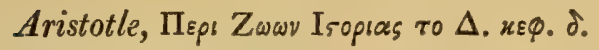

Pliny, Naturalis Historia Lib. 9.

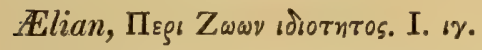

Vincentius, Speculum Naturale, 1473. fol.

Albertus Magnus, de Animalibus, \&c. 1478. fol.

Adam Lonicerus, Historiæ Naturalis Opus Novum. 1551, fol. et tom. 2. 1555. fol.

Belon, De Aquatilibus. 1553. 8vo.

Rondeletius, Universa Aquatilium Historia. 1544-55. fol.

Matthiolus, Comment. in sex Lib. Dioscoridis. 1565. fol.

Gesner, De Piscium et Aquatilium Animantium Historiâ Lib. 4 . 1558. fol.

Linocier, Histoire des Poissons. 1584. $12 \mathrm{mo.}$

Imperato, Dell' Historia Naturale Lib. 28. 1599. fol.

Aldrovandus, De Mollibus Crustaceis, Testaceis, et Zoöphytis. 1606. fol.

Fabius Columna, Aquatilium et Terrestrium aliquot Animalium, \&c. 1616. et 1675. 4to.

Basil Besler, Fasciculus Rariorum, \&c. 1616. fol. 
Chicco, Museum Calceolarium. 1622. fol.

Schonvelde, Ichthyologia, \&c. 1624.

Nierembergius, Historiæ Naturæ. 1655. fol.

Michael Rupert Besler, Gazophylacium Rerum Naturalium. 1642. fol.

Wormius, Museum Wormianum. 1655.

Moscardo, Note del Museo del Conte L. M. 1656. fol.

Jonston, Historia Naturalis, \&c. 165\% fol. De Exanguibus Aquaticis Lib. 4.

Power, Experimental Philosophy.

De Rochfort, Histoire Naturelle et Morale des Isles Antilles. 1665. 4to.

Adam Olearius, Kunst-Gammer, 1666. et 1674. 4to.

Du Tertre, Histoire Générale des Antilles, \&c. 1667. 4to.

Merrett, Pinax Rerum Natur. Britan. 1667.8vo.

Charleton, Onomasticon Zoicum. 1668. 4to.

Steno, De Solido intra Solidum, \&c. 1669. 4to.

Boyle, Philosophical Transactions of the Year 1670.

Willis, Exercitationes de Anima Brutorum. 1672. 8vo.

Legati, Museo Cospiano. 1671. fol.

Sir Robert Moray, Relation concerning Barnacles, Phil. Trans. vol. 12. 1678.

Harderus, Examen Anatomica Cochleæ Terrestris Domiportæ. 1679. 8vo.

Grew, Musæum Regalis Societatis. 1681. fol.

Buonanni, Recreatio Mentis, \&c. 1684. 4to. et Museum Kircherianum. 1709. fol.

Marsigli, Relazione del Ritrovamento, \&c. 1683. et 1695. $12 \mathrm{mo}$.

Boccone, Observazioni Naturali. 1684. $12 \mathrm{mo}$.

De Heide, Acta Eruditorum. 1684.

Cole, Phil. Trans. Abr. vol. 2. p. 826.

Lister, Historia Animalium Angliæ. 1678. 4to. Appendix. 1681. 4to. et Historia sive Synopsis Methodica Conchyliorum. 1685-93. fol.

Fehr, Eph. Acad. Nat. Cur. 1686.

Norman, Dissert. Acad. de Purpura. Upsal. 1686. 8vo.

Schelhammer, Eph. Acad. Nat. Cur. 1691. 
Brachius, Eph. Acad. Nat. Cur. 1690.

Du Molinet, Le Cabinet de la Bibliothèque de St. Geneviève. 1692. fol.

Banister, Phil. Trans. vol. 17. 1693.

Witzen, Phil. Trans. vol. 17. 1693.

Cunninghame, Phil. Trans. 1699.

Oliger, Jacobaus, Musæum Regium. 1696. fol.

Sir R. Sibbald, Auctarium Musæi Balfouriani. 1697. 8vo.

Ericus a Moinichen, A dissertation entitled Conche anatifera vindicata. 1679. 4to.

Leeuwenhoek, Philos. Trans. vol. 17. 1694. vol. 19. 1698. and vol. 27. 1712.

Leigh, Natural History of Lancashire, \&c. 1700. fol.

Wallace, Account of the Islands of Orkney, 2d edit. 1700. 8vo.

Petiver, Gazophylacium Naturæ et Artis. 1702. fol.

Plot, Natural History of Oxfordshire. 1705. fol.

Rumphius, Amboinsche Rariteitkamer. 1705. fol.

Poupart, Mémoires de l'Académie Royale des Sciences de Paris. 1706.

Levin Vincent, Wondertoonel der Nature. 1706. 4to.

Kamel, Phil. Trans. for the Year $170 \%$.

Reaumur, Mémoires de l'Académie Royale des Sciences de Paris. 1709-1717.

Ruysch, Thesaurus Animalium Primus. 17 10. 4 to.

Mery, Mém. de l'Acad. des Sciences. 1710.

Morton, Natural History of Northamptonshire. 1712. fol.

Cyprianus, Additions to Franzius's Historia Animalium Sacra. 1712. 4to.

Gottwald, Plates illustrative of his Museum. 1714.

Barrelier, Plantæ per Galliam, \&c. observatæ. 1714. fol.

John Henry Lochner, Rariora Musei Besleriani. 1716. fol.

Valentini, Amphitheatrum Zootomicum. 1720. fol.

Richard Bradley, Philosophical Account of the Works of Nature. 1721. 4to.

Langius, Methodus nova et facilis Testacea, \&c. 1722. 4to.

Bruckmann, De Curiosissimis duobus Corchis Marinis. 1722. 4 to. 
Frankenau, Act. Acad. Nat. Cur. 1722.

Valentyn, Oud en nieuw Ost-Indien, \&c. 1724.

Sloane, Voyage to the West Indies. 1725. fol.

Kundman, Promptuarium.

Stalport, Observationes Rariorum Medici, \&c. 1727. 8vo.

John Ernest Hebenstreit, An Academical Dissertation on the Arrangement of Testacea.

Dale, History and Antiquities of Harwich, $2 d$ edit. 1732. 4to.

Breynius, Dissertatio Physica de Polythalamiis. 1732. 4to.

Vallisneri, Opere Physico-mediche.

Sellius, Historia Naturalis Teredinis, \&c. 1733. 4to.

Rousset, Observations sur les Vers de Mer, qui percent les Vaisseaux. 1733. 8vo. 2d edit.

Bytemeister, Bibliotheca Appendix, sec. edit. 1735. 4to.

Deslandes, Recueil de différens Traitez de Physique et d'Hist. Nat. tom. 1, 1736.

Duhamel, Mémoires de l'Académie Royale des Sciences. 1736.

Srammerdam, Biblia Naturæ. 17.37. fol.

Plancus, De Conchis minus notis. 1739. 4to.

Gualtieri, Index Testarum Conchyliorum, \&c. 1742. fol.

D'Argenville, L'Histoire Naturelle éclaircie, \&c. 1742. 1757. et

1780. $3^{\text {e }}$ édition, augmentée par Favanne de Montcervelle. 2 tom. 4to.

Bartram, Phil. Trans. 1744.

Needham, Microscopical Discoveries. 174.5. Svo.

Lessers, Testaceo-Theologia. 1748 et 1756. Svo.

Dr. Churles Smith, Histories of Waterford, Cork, and Kerry. 1745,50 , and 56.8 vo.

Dr. James Parsons, Phil. Trans. vol. 45. and vol. 55.

Sir John Hill, History of Animals.

Mercier Du Paty, Recueil de l'Académie de Rochelle. 1759.

Klein, Tentamen Methodi Ostracologicx. 1753.

Jo. Henry Cohausen, Conspectus Sciographicus Testaceorum. 1754. 8vo.

Nicholas Geve, Monatliche Belustigungen, \&c. 1755. 4to.

Dr. Whytt, Description of the Ovary of the Brucinum Ampuildtum. Edinb. Phys. and Lit. Essays. 7756. 
Guettard, Mém. sur différentes Parties des Sciences et Arts. 1770.

Mém. de l'Acad. des Sciences. 1756 et 1760.

John Frederick Hoffman, Act. Acad. Mogunt. 1757. 1761.

Count Joseph Ginanni, Opere Postume. 1755. fol.

Adanson, Histoire Naturelle du Sénégal. 1757. 4to.

Seba, Descriptio Thesauri Rerum Naturalium. 1758.

Borlace, Natural History of Cornwall. 1758. fol.

John Ellis, Phil. Trans, for 1758.

Edwards, Gleanings of Natural History. 1758 and 1760. 4to.

Linnœus, Systema Naturæ, \&c.

Regenfuss, Choix de Coquillages et de Crustacées. 1758. fol.

Baster, Opuscula Subseciva. 1759-1765. 4to.

Brisson, Mém. de l'Acad. Roy. des Sciences. 1759.

Dr. Forbes, Phil. Trans. 1759.

Knorr, Les Délices des Yeux et de l'Esprit. 1760-1773, 4to, et

Deliciæ Naturæ selectr. 1766. fol.

De Bergen, Classes Conchyliorum. 1760. 4to.

Schotterbeccius, Acta Helvetica. 1760 et 1762.

Hofer, Acta Helvetica. vol. 4. 1760.

Koelreuter, Nov. Comment. Acad. Sc. Imp. Petrop. 1761 et 1766.

Ledermuller, Amusement Microscopique. 1764. 4to.

Herissaut, Mém. de l'Acad. des Sciences. 1766.

Davila, Catalogue Systématique et Raisonné. 1767. 8vo.

Fougeroux, Mém. Etrang. de l'Acad. Roy. des Sciences. 1768.

De La Faille, 1780 .

Geoffroy, Traité Sommaire des Coquilles, \&c. 176\%.8vo.

Duchesne, Recueil des Coquilles Fluviat. et Terrest. \&c. 3 planches. fol.

Cotte, Journal des Sçavans 1770, et Journal de Physique, tom. 3. Wallis, History and Antiquities of Northumberland. 1769. 4to.

Martini and Chemnitz, Neues Systematisches Conchylien Cabinet. 1769-1788.

Favert d'Herbigney, Dictionnaire d'Histoire Naturelle, qui concerne les Testacées, ou les Coquillages de Mer, de Terre, et d'Eau-douce. 1775.

Schröter, Einl. in die Conchyl. 1783. Svo. 
Rutty, Essay towards a Natural History of the County of Dublin. 1772. 8vo.

Brunnick, Fundamenta Zoologica.

Müller, Vermium Terrestrium et Fluviatilium Historia, \&c. 1774.

4to. Prodromus. 1776. 8vo. Zool. Dan. 1779. Svo.

Fortis, Viaggio in Dalmazia. 1774. 4to.

Forskahl, Descriptiones Animalium, \&c. 1775. 4to.

Slabber, Naturk. Verlust. 1788. 4to.

Gronovius, Zoophylacium Gronovianum. 1781. fol.

De Joubert, Mémoire sur une Coquille de l'Espèce des Poulettes,

\&c. Mém. Etrang. de l'Acad. des Sciences. 1774.

Kämmerer, Die Conchyl. in Cab. der Hernn. \&c. 1786. Svo.

Otho Fabricius, Faun. Groenland. 1780. 8vo.

Pallas, Miscellanea Zoologica. 1766. 4to. \& Spicil. Zool. $1767-80$.

Dr. Macbride, Phil. Trans. vol. 64. 1774.

Bonnet, Journal de Physique. 1775.

Pennant, British Zoology. 1778.

Scopoli, Introductio ad Historiam Naturalem. 1777. Svo.

Baron Born, Testacea Musei Cresarei, \&c. 1780. fol.

Da Costa, Elements of Conchology, 1776; and British Conchology, $17 \% 8$.

Dicquemare, Journal de Physique. tom. 18. 20. et 28.

Molini, Saggio sulla Storia Naturale del Chili. 1782. 8vo.

Spallanzani, Mem. della Soc. Ital. 1782 et 1784.

Lightfoot, Phil. Trans. vol. 76 .

George Humphreys, Linnæan Transactions, vol. 2. 1794. 4to.

Martin, Universal Conchologist. 1784 and 1786. fol.

William Boys \& George Walker, Testacea Minuta Rariora. 1784.

Lefebure des Hayes, Journal de Physique, for 1787.

Retzius, Nova 'Testaceorum Genera. 1788. 4to.

Le Gentil, Mém. de l'Acad. Roy. des Sciences, for 1788.

Cordiner, Remarkable Ruins, \&c. 1788-1795. 4to.

Soldani, Testaceographia, \&c. 1789-1795.4to.

Bonvicini, Mem. della Soc. Ital. 1794.

Mesaize, Magazin Encyclopédique. 1797. 
Bruguiere, Encyclopédie Méthodique, Article, Vers. 1789. Journ. d'Hist. Nat. tom. 1.

Dr. Shaw, Naturalist's Miscellany.

Olivi, Zoologica Adriatica. 1792. 4to.

Ribaucourt, Journal d'Hist. Nat. tom. 1.

Cuvier, Ann. du Mus. d'Hist. Nat.

Adams, Linnean Transactions, vol. 3.

MM. Leopold à Fichtel \& J. P. Charles à Moll, Testacea Microscopica, \&c. 1798. 4to.

Lamarck, Animaux sans Vertèbres, 1801. Annales du Mus. d'Hist. Nat. \&c.

William George Maton, Observations on the Western Counties. 1797. 8vo. Transactions of the Linnæan Society, vol. 3. 7. 8. 10. Hatchett, Philosophical Transactions. 1799.

Donovan, Natural History of British Shells. 1799. 8vo.

William Wood, Transactions of the Linnæan Society, vol. 6.

Zoography, or the Beauties of Nature displayed. 1807.8vo. vol. 2. Dufresne, Annales du Mus. d'Hist. Nat. tom. 1. Montagu, 'Testacea Britannica. 1809. 4to.

Denys de Montfort, Conchyliologie Systématique. 1808. 8vo. 



\section{DICTIONARY OF TERMS.}

A.

Adherent. - - The Mollusca adhere to thin shells.

Adherent. - - - A shell which attaches itself is adherent. Oysters adhere to rocks.

Adherent. - - - An operculum is adherent, when fixed to the animal. ANTERior. - - That half in Bivalve shells, which shows the cardinal ligament.

Aperture. - - The mouth of a shell.

Apex. - - - The tip, or small end of a shell.

Articulation. The insertion of parts of shells into each other. The fossil Cornu Amnonis is an instance of a series of articulations.

Articulation. - The tentacula of the animals of Barnacles, have articulations.

Articulation. - The teeth of bivalve shells are frequently articulated within each other.

Auriculated. Having ears. The Pectens are auriculated. Axıs. - - - In univalve shells the centre, or pillar, upon which the spires turn.

B.

BASE. - - - The lower part of a shell, or that which is opposed to the summit, or point of the spire.

Base. - - - The species of the genus Lepas, fix themselves by their base, to rocks and other bodies.

BEAK. - - - The elongated base, of certain species of univalve shells, is called the beak. The genera Murex and Strombus, afford examples of beaked shells. 
Beak. - - The lengthened extremity of the valves in some bivalve shells. Certain Tellens have their anterior part prolonged into a beak.

Bifid. - - Separated down the middle by a slit. The teeth of bivalve shells, are often bifid, or double.

Bivalve. - A shell with two valves, or pieces, connected by a hinge.

Byssus. - - A substance spun by the animals of bivalve shells, such as the Muscle, and the Pinna; by which they attach themselves to rocks, and other bodies. In the Muscle it is called the beard.

C.

CANaL. - - The continuation of the mouth, or opening, of a shell, into a kind of beak, which becomes tubular, and forms a gutter, or groove. The genus Murex and Strombus, afford examples of a canal.

Cardinal. - Conchologists apply this word to the central, or principal teeth in the hinges of bivalve shells. The Cockle has four teeth; the two nearest the centre of the hinge, are the cardinal teeth. The Mactra has but one cardinal tooth.

CArno. - - See hinge.

Carina. - - See keel.

Cartilage. A solid substance harder than flesh, but not so hard as horn.

Chambered. Having divisions across the cavity in the hollow of the shell, separating or dividing the same into chambers. The Nautilus is a chambered shell.

Close. - - Shut together, without leaving any opening. It applies chiefly to bivalve shells. The valves of the Solen are open, those of the Muscle are close.

Columella. The interior part of the lip, situated in the opening, or mouth, very near the axis upon which the spires turn in univalve shells. In some shells, as the Cones, it is smooth ; in others, as the Volutes, it is toothed, or pleated. 
Compressed. - Nearly flat. Several of the Tellens are compressed shells.

Concamerated. The same as chambered.

Contour. - - - The exterior surface, and round the edge of a shell. The Tuns are round in their contour; the Murex is angular.

Corcelet. - - The part near the hinge in bivalve shells, to which the ligament is attached. It is remarkable in the shells of the genus Venus, and received one of those names from Linnæus, which disgrace the pages of his Systema Natura.

Cordiforme. - Heart-shaped. The Cockles and some other shells are cordiforme.

Coriaceous. - Hard and fibrous; of a substance between horn and skin.

Crenated. - - Having blunt teeth. The margins of many bivalve shells are crenated.

Crest. - - - Crested like the comb of a cock. Some oysters are crested.

D.

Decussated. - Striated crossways.

Dentated. - - Toothed. The margin of most Cockles are dentated.

Diaphonous. - Transparent when held to the light.

Digitated. - - Made in the shape of fingers. The lips of some shells of the genus Strombus are digitated.

Diverging. - - Separating from a point. The teeth in the Anomia placenta diverge.

Dorsal. - - - Belonging to the back.

E.

EARs. - - - External projections, nearly triangular, which are seen at the base of Pectens. 
EdGE. - - - See Margin.

EPidermis. - An outer skin, or membrane, which covers the surface of the majority of shells, and is, generally, very tenaceous. Some shells, such as the Cowries, and the Cones, are without an epidermis.

Equilaterat. The valves of bivalve shells are equilateral when they precisely resemble each other in size and form.

Equivalve. - When the two valves are pefectly alike. The Muscles and Cockles, are equivalve shells.

\section{F.}

Fente. - - The slit, or opening, which appears on the slopes of bivalve shells, near the hinge, when the valves are closed.

Fissure. - - A notch, or slit. The slit limpet, Patella fissura, is an example.

Fosset. - - The cavity containing the ligament. The fossets are placed at the hinge in some bivalves.

Fosset. - - - The teeth of the hinge in bivalves, are also received into fossets, or cavities, in the opposite valve.

Furrow. - - A gutter, or groove, which when bivalves are closed, runs along parallel to the hinge.

G.

Gapers. - - Shells whose valves never shut close. The Solens are gapers, at both ends, the Myc gape at one end only.

Giв воus. - - Protuberant. Some species of Murex are gibbous.

Gla B Rous. - Smooth, uniformly polished.

GRAINED. - - Dotted with small tubercles.

Groove. - - A hollow prolonged line, placed between two ridges. Cockles are grooved.

Grour. - - The union of several shells that adhere together. The Oysters, and the Barnacles, form in groups. 
H.

HingE. - - - The part under the summits, by which the sides of bivalve and multivalve shells are connected together. The hinge in most shells is toothed, but in some it is without teeth, as in Oysters and Muscles.

Hispid. - - - Covered with hairs. The Helix hispida is an example.

I.

Im вRICA ted. - Tiled. Shells are sometimes covered with scales, which impend over each other like tiles on a house. The ribs of the Cardium Isocardia are covered with imbricated scales. The valves of the Chiton are imbricated, or laying one over the other.

Imperforated. Which has no hole, that is, is not pierced. The Limpets are, for the most part, imperforated.

IMPRESSION. - A trace, or mark. The muscles with which the animals of bivalve shells are provided, leave a mark in the interior, which is called the muscular impression. Oysters have but one muscular impression, the $V$ eneres have two, and some shells three muscular impressions.

IN EQUILATERAL. Of unequal sides. Inæquilateral valves are those whose summits are farther from one end of the shell than the other. The Tellens, are generally inæquilateral.

Inequivalve. - Of unequal valves. Having one valve more convex, or of a different form from the other. The Pectens, the Oysters, and the Spondyles, are inæquivalve.

Involute. - - Without spires. The Limpets are involute.

J.

Juxtaposition. A successive and perpetual adjunction of cal- 
careous, or horny particles, exuding from the mantle, or body, of the Mollusca. It is these particles which form the successive layers that envelope the animal, and constitute the shell.

K.

KEEL. - - - A term applied to the back of shells that are shaped like a boat. The Chitons are keeled. The Paper nautilus is keeled.

L.

Labium. - - See Lip.

Lamina. - - A plate, or layer. An Oyster-shell heated in the fire separates into laminæ, or plates.

Latera L. - - Belonging to the side.

Lenticular. - Of a lens shape. The fossil Numularia are lenticular shells.

Lid. - - - See Operculum.

Lip. - - - - The last turn of the spire in Univalves.

Lip. - - - - The Cowries have two lips, one right, and the other left.

Lip. - - - - In Bivalves. The exterior edge of the valves.

Ligament. - A horny substance uniting the valves of shells together at the hinge. Almost all Bivalies are united by ligament. It is interior in Oysters, and exterior in Muscles.

Linear. - - Very narrow.

LiNGUIFORM. - Tongue-shaped.

Longitudinal. Lengthwise. The longitudinal measure of a shell in Bivalves, is always from the hinge to the margin, however narrow the shell may be. In Univalves, from the apex to the base.

M.

MARgin. - - The edge of a shell. Some Bivalve shells have their margins plain, some waved, and others crenated, or dentated, \&c. 
Membrane. - A skin, or pellicle, susceptible of being inflated like a bladder. The Helix janthina has a membrane which it inflates like a bunch of grapes, or soap bubbles.

Mincte. - - A term applied to shells that require a lens to distinguish their several parts.

Moluusca. - Animals inhabiting shells, belong to the class Mollusca.

Moutr. - - The aperture, or opening of a shell. It is generally round, or long; though sometimes triangular, and even quadrangular.

Multilocular. Having several divisions, or compartments. All chambered shells are multilocular, and abound in the minute species.

Multivalve. - Having more than two valves. The Barnacle and the Pholas are multivalve shells.

Muscle. - - A flexible, fleshy, fibrous organ, by which the animals, especially of bivalves, are attached to their shells.

\section{O.}

Овцig ег. - - Diverging from right to left, or from left to right. Some shells are obliquely striated.

Oвtuse. - - Blunt pointed. The spire of the Volute is obtuse.

Operculum. - A solid, horny, or calcareous substance, generally round and flat, which fits exactly into the mouth of Univalves, and serves the animal as a lid, or cover, with which it can shut itself into its shell. Multivalves, such as the Lepas, have also an operculum.

Orbicular. - Of a round shape.

\section{P.}

Papyraceous. Thin as paper. The Paper Nautilus, is of this description.

Pedicle. - - A stalk. The Barnacles are raised on pedicles.

Pelagian. - Inhabiting the deep.

VOL. I. 
Perforated. Pierced. The disk of the Haliotis, and the apex of the Patella Graca, are perforated.

Pillar. - - The axis upon which the spires turn in Univalve shells.

Pisiform. - - Of a pea shape.

Plain. - - Uniform, flat. The Anomia placenta, is a plain shell.

Plaited. - - Many Univalve shells are plaited on the columella, or pillar lip, which characterises their genera. The Volutes are plaited.

Plaited. - - When the margins of a Bivalve shell deviate from a straight line, they sometines form a plait. Thus one of the characters of the genus Tellen, is to have the anterior margin plaited.

Posterior. - That half from the hinge, in Bivalve shells, which does not show the cardinal ligament.

Pyriform. - - Pear-shaped. The Bulla ficus is a pyriform shell.

$$
\text { Q. }
$$

Quadrivalve. Four-valved. The operculum of the Acorn shell is quadrivalve.

R.

Reticulated. Like net-work. Many shells have their surfaces reticulated.

Ribs. - - - Protuberant striæ on the surface of a shell. The Cockles are strongly ribbed.

Rostrum. - - See Beak.

Rugose. - - Wrinkled. The surfaces of some shells are rough, or wrinkled. The Tellina rugosa, is one among many examples.

S.

Scabrous. - Rough, rugged. The sliells of the genus Chama have scabrous valves.

Serrated. - Toothed like a saw. Many Bivalve shells have their margins serrated, such as the Spondyles. 
Sinvous. - Waved, folded, or deeply lobed. The margin of a shell is sinuous, when it bends in and out.

Sinus. - - A deep cut. The Murex Babylonius has a sinus in the lip.

Siphon. - A prolonged tube, running sometimes through the partitions of chambered shells.

Spine. - - A lengthened point either straight or curved. The Thorny Woodcock, Murex Tribulus, has very İong spines.

Sprre. - - Each single, or separate turning, or circumvolution in a Univalve shell, is called a spire.

Spiral. - Univalve shells, having one or more spires, are called spiral.

STria. - - Very fine lines, either flat or raised; which cross the surface of shells in different directions. When they proceed from hinge to margin, they are called longitudinal striæ, and when in a contrary direction, transverse strix. Concentric strix are those which form the segments of circles.

Striated. - Charged with stria.

Summit. - The highest part of a shell. In Univalves it is the point of the spire.

Summit. - The upper part of the valves, in Bivalve shells, is called the summit. It is generally curved inwards, towards the hinge, which it surmounts.

Suture. - A toothed joint. The valves of some of the Acorn shells are connected by sutures.

T.

TеEтн. - - Angular plaits upon the pillar lip of Volutes, and some other shells.

Teeth. - - Protuberances, and fangs, on the hinges of Bivalve shells.

Tentacula. Delicate, fleshy bodies, with which animals of the class Mollusca, are provided; they are capable of contraction and extension, and are endued with extreme sensibility. The horns of the snail are its tentacula. 
TestaceA. - - All animals of the class Mollusca, which are covered with a solid roof of carbonate of lime, come under the denomination of Testacea.

Tiled. - - - See Imbricated.

Transverse. - Across. Bands, or striæ, running across a shell, are called transverse.

Tricuspidate. A shell armed with three short points: The Anomia tridentata is an example.

Trifrd. - - - Slit into three. A trifid tooth.

Trilobed. - - Having three lobes.

Tubercle. - A protuberance, or knob, raised on the surface of some shells. Several species of the genus Murex, are loaded with tubercles.

Turban. - - All the whirls, or spires, of a Univalve, taken collectively, are called the turban. The Helix planorbis, has a flat turban; the Trochus tuberculatus a short turban, and the Trochus Ziziphinus a produced turban.

TuRN. - - - The turn of a spire, is a single, but complete revolution. In the Nautilus, the last turn of the spire envelopes all the others.

U.

Uмво. - - - The same as summit.

UMBilicus. - A small hole at the bottom of some Univalve shells, formed in the thickness of the columella, or pillar.

UNDULATED. - Waved.

UNILOCULAR. - This term is used for Univalves, that have but one chamber. The Paper Nautilus, the Cowries, the Olives, \&c. are unilocular shells.

UNivalve. - A division of shells, composed of but one valve, or piece.

V.

VALVE. - - The testaceous covering of the Mollusca. When of a single piece, the shell is called Univalve; when of two pieces, Bivalve; and when formed of more parts than two, Multivalve. 
Vermiform. Having the shape of worms. The Serpula, are vermiform shells.

Vertex. - The top, or point of a shell.

VIVIPAROUS. Shells which are found equally on land and in water. The fresh-water Helices are often seen on the plants which border the rivers.

W.

WAVED. - - Some shells are flexuous, bent in and out, or waved.

WhIRL. - - The same as Spire. 



\section{TABLE OF CONTENTS.}

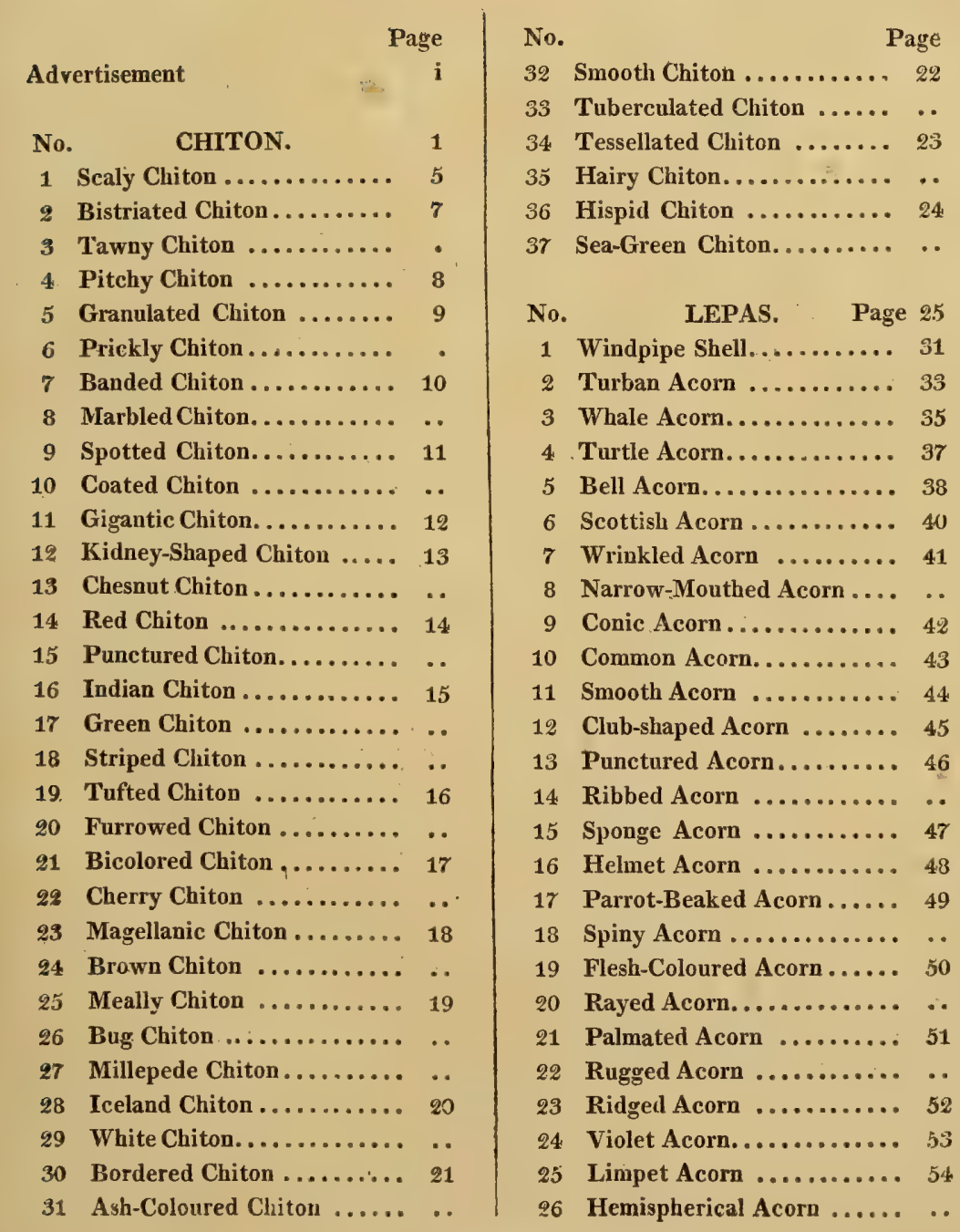




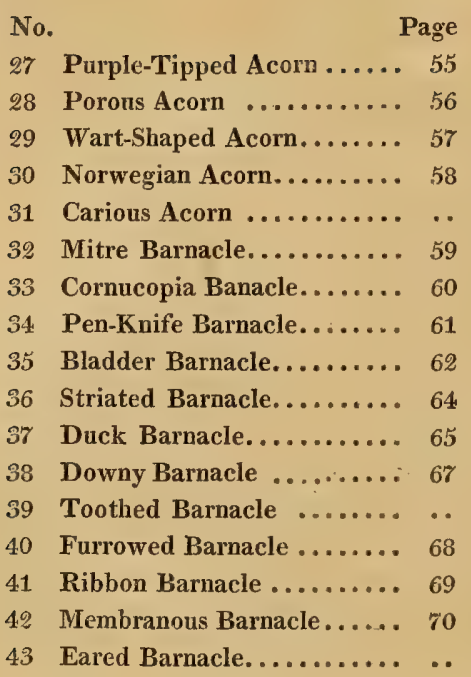

No. PHOLAS. Page 73

1 Prickly Piercer ......... 77

2 Indian Piercer ........... 78

3 White Piercer ........... 79

4 Ribbed Piercer.......... 80

5 Curled Piercer ............ 81

6. Small Pierce-Stone ....... 82

7 Striated Piercer ........ 83

8 Hooked Piercer ......... 84

9 Hart-Shaped Piercer ..... 85

10 Chili Piercer................

11 Gaping Piercer..............

12 Teredo Piercer.......... 86

\begin{tabular}{|c|c|}
\hline & Pag \\
\hline 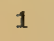 & Abrupt Gaper ........ \\
\hline 2 & Sand Gaper .......... \\
\hline 3 & Convex Gaper ........ \\
\hline 4 & Sloping Gaper ...... \\
\hline & Gaper... \\
\hline 6 & er........ \\
\hline & Grol \\
\hline 8 & r....... \\
\hline 9 & less Gaper ... \\
\hline & y Gaper ....... \\
\hline 11. & er...... \\
\hline & Beaked Gaper ...... \\
\hline
\end{tabular}

No. Page

13 Norway Gaper ........... 98

14 Membranous Graper........ ..

15 Deformed Gaper .......... ..

16 Double-Toothed Gaper .... 99

17 Decussated Gaper ...........

18 Purple Gaper .......... 100

19 Rusty Gaper...............

20 Glossy Gaper............. 101

21 Prismatic Gaper ............

22 Substriated Gaper ....... 102

23 Dubious Gaper.............

24 White Norway Gaper...... 103

25 Dutch Gaper................

26 Painters Gaper........... 104

27 Oval Gaper ............ 105

28 Thick Gaper............. 106

29 Knotted Gaper..............

30 Pearl Gaper ............ 107

31 Wrinkled Gaper ........ 108

32 Radiated Gaper ........ 109

33 Rough Gaper ..............

34 Knobbed Gaper ........ 110

35 Spurious Gaper.............

36 Angular Gaper ..............

37 Roundish Gaper ......... 111

38 Variable Gaper...............

39 Lipped Gaper .......... 112

40 Unequal-Valved Gaper .... 113

4.1 Great Gaper............ 114

No. SOLEN. Page 115

1 Pod Razor.............. 118

2 Carmarthenshire Razor .... 119

3 Sheath Razor...............

4 Truncated Solen ......... 121

5 Slender Razor .............

6 Sword Razor............. 122

7 Transparent Razor ....... 123

8 Peascod Razor........... 124

9 Kidney Razor ........... 125

10 Antiquated Razor.............

11 Brittle Razor............ 126

12 Strigilated Razor......... 127

13 Duck-Bill Razor ......... 128

14 Rayed Razor............... 


\begin{tabular}{|c|c|}
\hline No. & Page \\
\hline & Guinea Razor $\ldots \ldots \ldots \ldots 129$ \\
\hline 6 & Largest Razor ......... \\
\hline 18 & Great Razor ............ 130 \\
\hline 18 & Inflected Razor........... 131 \\
\hline 19 & Little Razor ................ \\
\hline 20 & Molini's Razor .......... 132 \\
\hline 21 & Green Razor ................ \\
\hline 22 & Violet Razor............ 133 \\
\hline 83 & Rose-Coloured Razor .......... \\
\hline 24 & Striated Razor ......... \\
\hline 2.5 & Zig-Zag Razor .............. \\
\hline 36 & Double-Rayed Razor ..... 135 \\
\hline 7 & Variable Razor............. \\
\hline 88 & Sanguine Razor.......... 136 \\
\hline 29 & Spotted Razor ......... 137 \\
\hline 30 & Spengler's Razor ........... \\
\hline 31 & Amethystine Razor ....... 138 \\
\hline & Variegated Razor......... 139 \\
\hline 33 & Minute Razor ............. \\
\hline 34 & Scale-Like Razor......... 140 \\
\hline 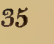 & Semi-Oval Razor ......... 141 \\
\hline
\end{tabular}

No.

1 Toothed Tellen........... 144

2 Cats-Tongue Tellen...........

3 Striped Tellen .......... 145

4 Freckled Tellen........... 146

5 Angular Tellen .............

6 Varying Tellen .......... 147

7 Brittle Tellen ........... 148

8 Rugged Tellen ..............

9 Inflated Tellen ........... 149

10 Pellucid Tellen..............

11 Multangular Tellen ....... 150

12 Paper 'Tellen..............

13 Gibbous Tellen........... 151

14 Unequal-Sized Tellen .........

15 Knorr's Tellen ..............

16 Minute Tellen ........... 152

17 Oblique Tellen..............

18 Spotted Tellen .......... 153

19 River Tellen ...............

20 Foliaceous Tellen.......... 154

21 Whitish Tellen .............

22 Thin Tellen .......... 155
No. Page

23 Semi-Striated Tellen ..... 156

24 Flat Tellen............. 157

25 Sharp-Edged Tellen..........

26 Rayed Tellen........... 158

27 Red Tellen............. 159

23 Beaked Tellen ..............

29 Smooth Tellen .......... 160

30 Three-Banded Tellen ...... 161

31 Donax Tellen ..............

32 Truncated Tellen......... 162

33 Triangular Tellen...........

34 Oblong Tellen .......... 163

35 Spengler's Tellen ...........

36 Carnation Tellen ......... 164

37 Blushing Tellen......... 165

38 White Tellen........... 166

39 Glassy Tellen.............

40 Lance-Shaped Tellen ...... 167

41 Opaline Tellen .............

42 Scarlet Tellen ........... 168

43 Chalky Tellen .............

44 Lister's Tellen .......... 169

45 Narrow Tellen .............

46 Madagascar Tellen ...........

47 Flat Striated Tellen ....... 170

48 Depressed Tellen......... 171

49 Purple Tellen ........... 172

50 Rough Tellen .............

51 Subcuneated Tellen...... 173

52 Broad Tellen...............

53 Jamaica Tellen.............

54, Whitish Tellen ........... 174

55 Reddish Tellen ............

56 Banded Tellen ..............

57 Striated Tellen .......... 175

58 Rosy Tellen ..............

59 Adanson's Tellen ........ $\mathbf{3 7 6}$

60 Reticulated Tellen ..........

61 Fasciated Tellen ......... 177

62 Snowy Tellen ............

63 Sulcated Tellen ......... 178

64 Angular Tellen ..............

65 Laskey's Tellen........... 179

66 Pomegranate-Flower Tellen 130

67 Rasp Tellen .............. 


\begin{tabular}{|c|c|}
\hline No. & $\mathbf{P a g}$ \\
\hline 38 & Smooth Tellen ........... 181 \\
\hline 5. & Waved Tellen .......... 182 \\
\hline 70 & Lattice Tellen ............. \\
\hline & Thread-Girdled Tellen .... 183 \\
\hline & Rough Tellen $\ldots \ldots \ldots \ldots$ 184 \\
\hline 73 & Prickly Tellen .......... 18. \\
\hline 72 & Obsolete Tellen ............. \\
\hline ( & Thick Tellen........... 186 \\
\hline 76 & Milky Tellen............ 187 \\
\hline 87 & Round Tellen $\ldots \ldots \ldots \ldots \ldots$ \\
\hline 85 & Crooked Tellen.......... 188 \\
\hline 79 & Flesh-Coloured Tellen ...... 189 \\
\hline 8 & Polygonal Tellen .......... 190 \\
\hline 81 & Decussated Tellen ........... \\
\hline 82 & Heart-Shaped Tellen ...... 191 \\
\hline 83 & Duuble-Spotted Tellen .... 192 \\
\hline 84 & Solid Tellen ............ 193 \\
\hline 85 & Baltic Tellen............ 194 \\
\hline 86 & Pea Tellen.................. \\
\hline 87 & Obliquely Striated Tellen .. 195 \\
\hline 88 & Toothed Tellen, .............. \\
\hline 89 & Digital Tellen ........... 196 \\
\hline 90 & Horn-Coloured Tellen ,...... . . \\
\hline 91 & Lake Tellen ............ 197 \\
\hline 92 & Spanish Tellen ........... 198 \\
\hline 93 & Sinuous Tellen $\ldots \ldots \ldots \ldots \ldots \ldots$ \\
\hline 94 & French Tellen ........... 199 \\
\hline $9 \breve{3}$ & Senegal Tellen...$\ldots \ldots \ldots$ \\
\hline 96 & Maton's Tellen ............... \\
\hline & Unequal-Valved Tellen ,.,. 201 \\
\hline
\end{tabular}

No. CARDIUM. Page 203

1 Spiny Cockle............. 207

2 Thorny Cockle ........... 208

3 Fringed Cockle........... 209

4 Tuberculated Cockle ...... 210

5, Marbled Cockle .........211

6 Pigmy Cockle ........... 21 2

7 Knotty Cockle ..............

8 Red Cockle .............213

9 Waved Cockle ..............

10 Pea Cockle ............ 214

11 Lengthened Cockle..........

12 Microscopic Cockle........ 215
No. Page

13 Banded Cockle........... 215

14 Prickly Cockle ........... 216

15 Imbricated Cockle ....... 217

16 Greenish Cockle ......... 218

17 Mottled Cockle..............

18 Toothed Cockle ......... 219

19 Prominent Cockle ........ 220

20 Great Cockle............. 221

20* Smooth Cockle.......... 222

21 Citron Cockle ........... 223

22 Oblong Cockle .............

23 Yellow Cockle ........... 224

24 Banded Cockle........... 225

25 Common Cockle.......... 226

26 Iceland Cockle........... 297

27 Greenland Cockle............

28 Equal-Sided Cockle........ 298

29 Pectinated Cockle ....... 229

30 Eared Cockle...............

31 Asiatic Cockle ........... 230

32 Paper Cockle ..............

33 Ribbed Cockle........... 231

34. Gaping Cockle.......... 232

35 Solen Cockle............ 233

36 Pecten Cockle .............

37 Donax Cockle .......... 234

38 Furbelowed Cockle...........

39 Janus Cockle............ 235

40 Rough Cockle ........... 236

41 Broad Cockle .............

42 Flexuous Cockle ......... 237

43 Decussated Cockle ..........

44 Rusty Cockle ........... 298

45 Whitish Cockle.............

46 Greenish Cockle ...........

47 Streaked Cockle ..........

48 Rose Cockle ...............

49 Triangular Cockle ....... 240

50 Strawberry Cockle ........ 241

51 White Strawberry Cockle .. 244

52 Diana Heart Cockle....... 24:3

53 Spiny-Keeled Heart Cockle 244

51 Snooth-Keeled Heart Cocklc 245 


\section{A LIST OF PLATES.}

\begin{tabular}{|c|c|c|c|c|c|c|c|}
\hline 1 & $\begin{array}{c}\text { PL. } 1 . \\
\text { Chiton squamosus }\end{array}$ & $\begin{array}{c}\text { Page } \\
5\end{array}$ & $\begin{array}{r}\text { No. } \\
1\end{array}$ & 1.2.3.4 & $\begin{array}{l}\text { PL. } 8 . \\
\text { Lepas crispata }\end{array}$ & $\begin{array}{c}\text { Page } \\
51\end{array}$ & $\begin{array}{r}\text { No. } \\
22\end{array}$ \\
\hline 2 & ...... fulvas & 7 & 3 & 5 & .....pporcata & 52 & 23 \\
\hline 3 & ..... piceus & 8 & 4 & \multicolumn{4}{|c|}{ PL. 9.} \\
\hline 4. 5. & ...... fasciatus & 10 & 7 & 1.2 .3 & Lepas purpurascens & is 55 & 27 \\
\hline \multicolumn{4}{|c|}{ PL. 2.} & 4 & ......p porosa & 56 & 28 \\
\hline 1 & Chiton tunicatus & 11 & 10 & 5 & ...... Verruca & 57 & 29 \\
\hline 2. 3 . & ...... castaneus & 13 & 13 & \multicolumn{4}{|c|}{ PL. 10.} \\
\hline 4.5 & ...... lineatus & 15 & 18 & 1 & Lepas Mitella & 59 & 32 \\
\hline 6 & ..... facicularis & 16 & 19 & 2 & ...... Pollicipes & 60 & 33 \\
\hline & $\quad \quad$ PL. 3. & & & 3 & ...... Scalpellnm & 61 & 34 \\
\hline 1 & Chiton sulcatus & 16 & 20 & 4 & ...... fascicularis & 62 & 35 \\
\hline 2. 3 . & ...... castaneus & 13 & 13 & 5 & ...... anserifera & 64 & 36 \\
\hline 4 & ...... marginatus & 21 & 30 & \multicolumn{4}{|c|}{ PL. 11.} \\
\hline 5 & ...... cinereus & 21 & 31 & Lepas an & atifera & 65 & 37 \\
\hline 6 & ...... Magellanicus & 18 & 23 & \multicolumn{4}{|c|}{ PL. 12.} \\
\hline & PL. $4 . *$ & & & \multicolumn{4}{|c|}{1 Lepas sulcata } \\
\hline \multirow{2}{*}{ 1. 2.3} & Lepas Tracheæformis & 31 & 1 & \multicolumn{4}{|c|}{$2.3 \ldots .$. vittata } \\
\hline & PL. 4. & & & \multirow{2}{*}{\multicolumn{4}{|c|}{ 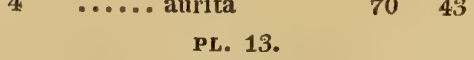 }} \\
\hline Lepas & Diadema & 33 & 2 & & & & \\
\hline & PL. 5 . & & & \multirow[t]{2}{*}{1.2 .3} & Pholas Dactylus & s 77 & 1 \\
\hline 1.2 .5 & 3 Lepas balænaris & 35 & 3 & & \multicolumn{3}{|l|}{ PL. 14.} \\
\hline 4 & ...... testudinaria & 37 & 4 & \multirow{2}{*}{$\begin{array}{l}1.2 \\
3.4\end{array}$} & Pholas orientalis & is 78 & 2 \\
\hline & PL. 6 . & & & & ...... candida & 79 & 3 \\
\hline 1. 2 & Lepas tintinnabulum & 38 & 5 & 3.4 & \multicolumn{3}{|l|}{ PL. 15.} \\
\hline 3 & ...... Scotica & 40 & 6 & 1.2 & Pliolas costata & 80 & 4 \\
\hline 4 & ..... rngosa & 41 & 7 & 3.4 .5 & ...... crispata & 81 & 5 \\
\hline \multirow[t]{2}{*}{5} & ...... angustata & 41 & 8 & \multicolumn{4}{|c|}{ PL. 16.} \\
\hline & PL. 7 . & & & \multicolumn{2}{|c|}{ 1.2.3.4.\& 8 Pholas striata } & 83 & 7 \\
\hline 1 & Lepas balanoides & 44 & 11 & 5.6 .7$. & ..... falcata & 34 & 8 \\
\hline 2 & ...... clavata & 45 & 12 & \multicolumn{4}{|c|}{ PL. 17 . } \\
\hline 3 & ...... Balanus & 43 & 10 & 1.2 Mya & a truncata & 90 & 1 \\
\hline 4. 5 & ..... spinosa & 49 & 18 & $3 \quad \ldots$ & - arenaria & 91 & 2 \\
\hline 6 & ..... minor & 50 & 19 & \multicolumn{4}{|c|}{ PL. 18.} \\
\hline 7 & ..... radiata & 50 & 20 & 1. Mya & a convexa & 92 & 3 \\
\hline
\end{tabular}


2.3 Mya declivis

4. 5 .... Norwegica PL. 19.

1.2 Mya Batava

3. 4 .... Pictorum

5 .... ovata

PL. $20 \& 21$.

Mya crassa

PL. 22.

1.2.3.4 Mya nodulosa

$5 \quad$.... picea

PL. 23.

1.2.3 Mya margaritifera $107 \quad 30$ PL. 24.

1.2.3 Mya corrugata $108 \quad 31$

$\begin{array}{lllll}4.5 .6 & \text {.... globosa } & 95 & 7\end{array}$

$7.8 .9 \quad \ldots$ prætenius $\quad 94 \quad 5$

PL. 25.

1 Mya Glycimeris $114 \quad 41$

2.3 ... dubia $102 \quad 23$

PL. 26.

1. 2 Solen Siliqua $116 \quad 1$

3. 4 ..... truncata $121 \quad 4$

p. 27.

1 Solen Vagina $119 \quad 3$

$2 \quad$..... truncata $121 \quad 4$

3 ..... linearis $121 \quad 5$ PL. 28.

1.2 Solen Ensis

1226

3 ..... pellucidus $123 \quad 7$

4. 5 ..... Legumen $124 \quad 8$

PL. 29.

1.2 Solen Cultellus $125 \quad 9$

$3 \quad$..... antiquatus $125 \quad 10$

4.5 ..... fragilis $126 \quad 11$

PL. 30 .

$1 \quad$ Solen strigilatus $127 \quad 12$

2.3.4 $\ldots$... anatinus $128 \quad 13$

PL. 31.

1.2. Solen radiatus $128 \quad 14$

3 $\quad$.... maximus $129 \quad 16$

PL. 32.

1.2 Solen inflexus

$131 \quad 18$

3 Diphos
Page No.

PL. 33.

1 Solen biradiata $135 \quad 26$

$2.3 \quad$.... vespertinus $135 \quad 27$

4. $5 \quad$..... sanguinolentus $136 \quad 28$

PL. 34 .

1 Solen Amethystus $138 \quad 31$

2.3.4 .... variegatus $139 \quad 32$

$\begin{array}{lll}5.6 & \text {.... minutus } \quad 139 \quad 33\end{array}$

pL. 35.

1 Tellina scobinata $\quad 180 \quad 67$

2.3 ..... virgata 145.3

PL. 36.

1 Tellina foliacea $\quad \begin{array}{lll}154 & 20\end{array}$

$2 \quad$...... virgata $145 \quad 3$

3..... interrupta $146 \quad 4$

PL. 37

1 Telina lrevis $\quad 181 \quad 68$

$2 \quad \ldots$... Spengleri $163 \quad 35$

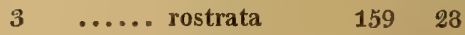

PL. 38.

1 Tellina Remies $\quad 182 \quad 69$

2. 3 ..... radiata $158 \quad 26$

PL. 39.

1 Tellina punicea $\quad 170 \quad 47$

2.3 ......Madagascariensis $169 \quad 46$ PL. 40.

1 Tellina crassa $186 \quad 75$

2. 3 ..... Lingua-felis 144 2

$4.5 \quad \ldots .$. carnaria $\quad 189 \quad 79$ PL. 41.

$1 \quad$ Tellina lævigata $\quad 160 \quad 29$

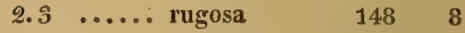

$4.5 \quad \ldots .$. obliqua $\quad 152 \quad 17$

PL. 4.2.

1 Tellina operculata $165 \quad 37$

$2.3 \quad \ldots .$. reticulata $182 \quad 70$

$4.5 \quad \ldots .$. Radula $\quad 133 \quad 71$

PL. 43.

1 Tellina angulata . $146 \quad 5$

$2.3 \ldots .$. decussata $\quad 190 \quad 81$

4.5 ..... cordiformis $191 \quad 82$

PL. 44.

1 Tellina acuta $157 \quad 25$

$2 \quad \ldots \ldots$ sanguinea $\quad 159 \quad 27$ 
Page No.

3. 4 Tellina tenuis $155 \quad 22$

PL. 45.

1 Tellina Ferröensis

164. 36

2 ..... lanceolata $167 \quad 40$

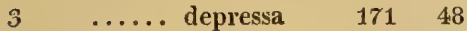

$4 \quad$..... fabula $156 \quad 23$

$5 \quad$..... donacina 16131

6. $7 \quad$.... bimaculata $192 \quad 83$ PL. 46.

1 Tellina nivea

$177 \quad 62$

2 ..... solidula

19384

$3 \quad$...... cornea $\quad 196 \quad 90$

4.5 ..... limosa $199 \quad 96$

$6 \quad \ldots .$. divaricata $195 \quad 87$

$7 \quad$..... dentata $195 \quad 88$

PL. 47 .

$1 \quad$ Tellina sulcata $\quad 178 \quad 63$

2.3. $4 \ldots$.... inæquivalvis 201.97

$5 \quad$..... lacustris $197 \quad 91$

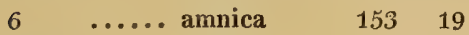

$\begin{array}{lllll}7.8 & \text {..... flexnosa } & 188 \quad 78\end{array}$

PL. 48 .

Cardium aculeatum

PL. 49.

1.2 Cardium echinatum

$208 \quad 2$

3. 4 ....... ciliare

PL. 50.

1.2 Cardium tuberculatum $210 \quad 4$

$3 \quad$.......medium $211 \quad 5$

PI. 51.

1 Cardium aculeatum $207 \quad 1$

$2.3 \ldots . .$. muricatum $216 \quad 14$
Page No.

PL. 52.

1. 2 Cardium isocardia $217 \quad 15$

$\begin{array}{llll}3 & \ldots & \ldots & \text { maculosum } 218 \quad 17\end{array}$

PL. 53.

1. 2 Cardium ringens $\quad 219 \quad 18$

3 ....... magnum $221 \quad 20$

PL. 54 .

1. 2 Cardium lævigatum $222 \quad 20$

$3 \quad \ldots \ldots$ citrinum $223 \quad 21$

PL. 55 .

1 Cardium oblongum $.223 \quad 22$

$2.3 \ldots \ldots$ rusticum $225 \quad 24$

$4 . \ldots \ldots$ edule $\quad 226 \quad 25$

$5 \quad$....... papyraceum $230 \quad 32$

PL. 56.

1 Cardinm costatum $231 \quad 33$

$2 \quad \ldots \ldots$ apertum $232 \quad 34$

$3 \quad$........ soleniforme $233 \quad 35$

$4.5 \ldots \ldots$ fimbriatum $234 \quad 38$

PL. 57.

1 Cardium Æolicum $235 \quad 39$

$2.3 \ldots \ldots$ rigidum $236 \quad 40$

$4.5 \ldots .$. latum $\quad 236 \quad 41$

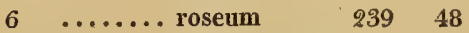

$7.8 \ldots \ldots$ hemicardium $240 \quad 49$

PL. 58.

1.2 Cardium Fragum $241 \quad 50$

$3 \quad \ldots . .$. Unedo $242 \quad 51$

$4.5 \ldots .$. retusum $243 \quad 5 \%$

PL. 59.

1. 2 Cardium Cardissa $244 \quad 53$

3. $4 \ldots . .$. humanum 245 



\title{
MULTIVALVE SHELLS.
}

\author{
Genus 1. \\ C H I T O N. \\ GENERIC CHARACTER。
}

Animal Lophyrus.

Testa plures longitudinaliter digestæ, dorso incumbentes.

Animal a Lophyrus.

Shells (valves or plates) many, arranged longitudinally, and resting on the back.

\section{GENERAL OBSERVATIONS.}

Poli, in the third plate of his splendid work on the shells of the two Sicilies, has given a complete anatomical figure of the animal of the Chiton, from which it appears not to be a Doris, as supposed by Linnæus, but sufficiently distinct to constitute a new genus. The animal has an oval body, flat beneath, without eyes or tentacula, an oval foot; a head surmounted by a crest, with a wrinkled mouth beneath: the exterior air vessels are separate, pinnated, and placed round the body, between the mantle (or folding muscle) and the foot. It is obvious that it differs from a Doris in the want of tentacula, (or feelers), and in the presence of a crest, a distinction upon which Poli has established his genus, and from whence he has derived his greek name ró

Chitons are to Testacea what armadillos are to quadrupeds, and millepedes to insects; that is, like them voL. I. 
they are capable of contraction and extension; they can stretch at full length, or roll themselves into a ball. The scales, or valves, of which they are formed, are from six to eight in number, and are so disposed, that they move on each other like the joints on the tail of a lobster. The valves which are very solid, vary in shape and colour according to the species, but the smallest is generally before and the largest behind: they are connected together by a projecting cartilaginous border which surrounds the shell, and which is sometimes plain, sometimes spinous, and often covered with minute scales.

The name of petite nacelle, which has been occasionally given to this shell, is by no means unapplicable, for nothing can convey a better idea of a little boat than the interior of a Chiton. In some species the colour of this surface is bluish green, in some it is quite white; others are stained with violet, or purple, along the middle, and some are very prettily variegated.

Chitons fix themselves to rocks, to ships, and even frequently to fish, and to other shells. They are capable of locomotion, but seldom appear to use that faculty; they seem to be satisfied with their first attachment, and never wish to change their place. When forced from their hold they roll themselves into a ball, presenting nothing to their enemy but an invulnerable shell, and a portion of the lateral ligament defended by scales, or spines. Bosc observed, on the coast of America, that when the Chitons rolled themselves up in consequence of being separated by violence from the bodies to which they were fixed, it was a considerable time before they recovered their natural position; the most expeditious required two days to compose themselves, and several, 
which Bosc supposed must have been wounded, remained a week in a contracted state.

These shells have been called by different names, all however indicative of their form, such as wood-louse, sea boat, rattle-snake's tail, lobster's tail, sea bug, and sea caterpillar. The French say that the animal may be eaten, and we are told that the Iceland fishers swallow it raw to quench their thirst, and pretend that it is good also against sea sickness. These shells are found, but rarely in abundance, on the coasts of North and South America, in the Straits of Magellan, on the coast of Africa, in the West Indies, in Carolina, on the coasts of France, England, \&c.

It must be observed, that the subjects of this genus, before the time of Linnæus, were scattered about in authors, without being referred to any particular class; but the systematic plan of the great Swedish naturalist, forced him to decide upon their situation, and he accordingly gave them a place among the testaceous multivalves. How far they are entitled to rank with the shells, in preference to the marine insects, will certainly admit of dispute, since, unlike all other Testacea, their valves are formed of an intermediate substance between carbonate of lime and animal gluten. The following experiments will prove that this assertion is not without foundation.

A Chiton marginatus, weighing two grains, effervesced strongly in muriatic acid, and lost seven-eights of its weight; the remainder was animal gluten, and retained the perfect form of the shell.

A valve of the Chiton squamosus weighing twenty grains, lost in muriatic acid nine-tenths of its weight, the animal part which was undissolved, retained (before it was dried) the form and colour of the valve, the 
striæ also remaining so that the species might be readily distinguished.

A valve of a Chiton from the Red Sea, weighing eighteen grains, lost seventeen in the process, but the grain that remained, while it was wet, retained all the marks of the original shell. In this experiment the solution was not attended with so rapid an extrication of gas as in the two former. Ten grains of the Bulla hydatis, on the contrary, being subjected to the same test, left merely a white transparent film.

This striking difference in the composition of the shell of the Chiton from that of other Testacea, added to its general appearance, will furnish sufficient grounds to dispute its title to its present situation, but the plan of this work being strictly to follow the Linnæan arrangement, the Author has not hesitated to commence his specifications with this genus.

In the twelfth and last edition of the Systema Naturæ by Linnæus, we find but nine Chitons enumerated. Gmelin, in his enlarged edition, has noticed twentyeight, and the reader will perceive that in the present work, the number has been still further increased, by the addition of several new species. 


\section{* With Eight Valves.}

\section{SCALY CHITON.}

Pl. 1.fig. 1. Mr. JenNings.

1. Chiton squamosus. Ch.testa octovalvi semistriata, corpore squamuloso. Linn. Gmel. p. 3203.

Shell of eight semistriated valves, margin covered with minute scales.

Patella oblonga articulata, articulis striatis, extus subfuscis intus e virids caruleis. Sloane Hist. Jam. t. 2. p. 233.

Chiton squamosus, color testa atro virescens, cavitatis viridi caruleus, squamularum albus et niger. Born. Mus. Caes. p. 5. t. 1. fig. 1. 2.

Petiver Gazoph. t. 1. f. 4. Spengler Besch. Berl. Naturf. 1. p. 292. t. 7. f. L. M. Edw. av. t. 286. f. D. Encyclop. Method. Art. Vers. pl. 162. f. 5. 6.

The notice which Sir Hans Sloane has taken of this species, in his Natural History of Jamaica, is concise and satisfactory. His account is as follows. "This which sticks to rocks under the sea water in Jamaica after the manner of limpets, is about two inches long, one broad, made up of eight pieces, or joints laid over one another. Each of the six middlemost joints is striated two ways on each side, and smooth in the top or middle, of a dark brown colour above, and bluish green underneath. The whole margin is made up of a skin on which are many round raised points, which are also on the first and last joint of the shell. I found it of several magnitudes sticking to the rocks under water on the north side of the island of Jamaica.-I have had joints of it from Nieves."

It will be proper to observe, in addition to $\operatorname{Sir} \mathbf{H}$. Sloane's account, that this shell in common with the majority of the genus, when seen sideways, exhibits a double series of triangles, formed by the middle valves, six of these, which may be called marginal triangles, have their base in the scaly margin, and their apex on the back of 
the shell, they are strongly striated longitudinally, and the striæ, when particularly examined, appear to be placed in a quincunx order. The other six are formed in the intervals of the marginal triangles, having their base on the back of the shell, and are marked with curvilinear striæ, in a contrary direction. These, which may be called the dorsal triangles, are perfectly smooth at the base. The margin resembles the skin of a snake, being covered with minute black and white scales These scales are of the same nature as the valves, and effervesce strongly in mineral acids. The general colour of the shell is dark brown, or olive: the interior always light green.

Chemnitz, though he has quoted the synonyms of the Chiton squamosus, has figured a distinct shell, and Gmelin has unhappily jumbled together several species under the same title. It seems that all those shells with a scaly border, however they might differ in other respects, were to be considered as varieties only of the same species. This has produced much confusion in the genus, which it will be the object of the following specifications to rectify. The shell is an inhabitant of America.

The scaly Chiton is well figured by Edwards, but erroneously quoted by Linnæus for Chiton aculeatus. Born's figure is good, his description accurate. Spengler's represention is most excellent, and the figures in the French Encyclopedia are very good. Seba's figure, quoted by Linnæus, must be rejected, it is a bad representation of the interior. Gmelin's variety $\delta$. is the Chiton marginatus, Oscabrion gallicum of Argenville. 


\section{BISTRIATED CHITON.}

2. Chiton bistriatus. Ch. testa octovalvi, bistriata, margine squamuloso. Shell of eight valves with double strix, margin scaly.

Chiton squamosus. Chem. Conch. 8. t. 94. f. 788-791. Chem. Chiton t. 1. fig. 1.

The two extreme valves are greenish ash colour dotted with brown, the middle valves are red brown, with double curvilinear strix of equal strength from the dorsal ridge to the margin. The marginal triangles are marked with dark brown spots on a light bluish-green ground; margin scaly, fasciated with bistre.

This shell is so evidently different from the true Chiton squamosus, that the propriety of its separation must be obvious. It may be presumed that Chemuitz was not in possession of the dark green shell described by Born and others.

\section{TAWNY CHITON.}

Pl. 1. f. 2.

3. Chiton fulvus. Ch. testa octovalvi striata, striis albidis, lineato punctatis, limbo coriaceo.

Shell of eight valves, striated, striæ in whitish dotted lines, margin coriaceous.

Chiton candidatus Gaditanus. Chem. Conch. 10. t. 173. f. 1691.

Encyclop. Method. Art. Vers. pl. 161. f. 4, 5.

The middle valves, in this shell, are marked on the dorsal triangles with numerous whitish lines occasionally running into each other. These striæ, when magnified appear moniliform, or like strings of minute white beads : the marginal triangles are also striated but not beaded. The extreme valves are marked like the middle ones. Ge- 
neral colour fawn or tawny, perfect shells deepest on the back, worn shells white at the apex of each valve.

Gmelin has referred this species to C. aculeatus, to which it has no affinity, but he has added a note of interrogation.

The subject represented in the Plate was brought from Portugal, but was probably taken in South America.

\section{PITCHY CHITON:}

Pl. 1. f. 3. Dr. Соомв E.

4. Chiton piceus. Ch. testa octovalvi, supra glabra picea, nigro albidoquo varia. Linn. Gmel. p. 3205.

Shell of eight valves, upper surface smooth, pitchy, varied with white and black.

Chem. Conch. 8. t. 96. f. 807-810. Chem. Chiton. t. 2. f. 6. Encyclop. Method.pl. 163. f. 3, 4, 5.

Chemnitz considers this species as a variety of the following, or granulatus, but its affinity lies in the margin only, which in both is coriaceous and spiny : in other particulars they differ essentially. The valves of the pitchy Chiton are rude and mishapen, with a smooth black band running along the back, and separated from the marginal division, on each side, by a broad white line. Near the margin the valves are dark, scaly, and covered with pitchy granulations. The shell within is black in the middle, the sides greenish.

This species inhabits the Red Sea, and American ocean. It is said sometimes, though rarely, to be found with six or seven valves. 


\section{GRANULATED CHITON.}

5. Chiton granulatus. Ch. piceus, supra planus, punctis elevatis numerosis in series digestis, limbo lato, coriaceo, spinoso: areis nigris albisque alternis. Linn. Gmel. p. 3205.

Pitchy, above flat, with numerous granulations disposed in regular rows; border broad, coriaceous and spiny, with alternate white and black patches.

Chem. Conch. 8. t. 96. f. 806.

This shell has eight valves; it inhabits the American ocean.

\section{PRICKLY CHITON.}

6. Chiton aculeatus. Ch. testa octovalvi striata, corpore subaculeato. Linn. Syst. Nat. p. 1106. Gmel. 3202.

Shell of eight striated valves, body somewhat prickly.

Chiton Nicobaricus aculeatus. Chem. Conch. 10. t. 173. f. 1692.

Limax marina. Rumph. Mus. t. 10. f. 4. Barbut. t. 1. f. 2.

Amcen. Acad. 8. t. 3. f. 1. Encyclop. Method.pl. 163. f. 6.

An oval shell, rough on the upper part, with narrow awl-shaped unequal prickles of a red colour; the valves are all striated transversely; the last valve is the smallest: the margin covered with bristles. Inhabits Asia, particularly the Red Sea.

The specimen figured by Chemnitz, appears to be coated with a red incrustation, so that the valves cannot be seen. It is not uncommon for shells of this genus to be disfigured by similar incrustations of different colours, but chiefly white. The editors of the French Encyclopedia have copied Chemnitz. Grmelin's variety ß. must be rejected, and also the reference to Edwards, who has figured C. squamosus, not C. aculeatus. 


\section{BANDED CHITON.}

\section{Pl. 1. $f$. 4, 5. Mr. JenNings.}

7. Chiton fasciatus. Ch. testa octovalvi scaber, valvis variegatis.

Shell of eight valves, rough, valves variegated.

Chiton crassus striatus. Chem. Conch. 8. t. 95. f. 801. Chem. Chiton,

t. 1. f. 3. Chiton scaber variegatis. Chem. Conch. 8. t. 94. f. 792.

The middle valves of this shell are elegantly fasciated with brown, a light streak runs along the keel, or ridge, with a darker line on each side; the dorsal triangles are perfectly smooth, but the marginal triangles, and the two extreme valves, are covered with granulated striæ, and variegated with brown undulations. The margin scaly, alternately varied with white and green; inside a glossy verdigrease green.

This shell varies in colour, being sometimes fasciated with light green, and having a black or dark brown band on each side the dorsal ridge. Inhabits South America.

The banded Chiton, has been erroneously quoted by Gmelin, for a variety of the C. squamosus. It resembles the following species in colour, but its rough valves will at once distinguish it from the C. marmoratus, which is entirely smooth.

\section{MARBLED CHITON.}

8. Chiton marmoratus. Ch. testa octovalvi glaberrima albo et nigricante varia, valvis mediis intus virentibus. Linn. Gmel. p. 3205.

Shell of eight valves, quite smooth, varied with white and black; middle valves greenish within.

Chem. Conch. 8. t. 95. f. 803-805. Chem. Chiton, t. 1. f. 5. Knorr. Vergn. 4. t. 17. f. 3, 4. Encyclop. Method. pl. 162. f. 11, 12.

This shell is subject to vary in the disposition of the colours, sometimes it is regularly banded like the 
C. fasciatus, as figured by Chemnitz, and sometimes uniform, or in patches, as in Knorr. The colours are black, or greenish, or deep red-brown on a lighter ground. The scaly margin is stained with blackish, or deep blue and white. Inhabits the American ocean.

The variety $\beta$. of Gmelin, quoted from Schröter, is too indistinct to be admitted.

\section{SPOTTED CHITON.}

9. Chiton maculatus. Ch. testa octovalvi glaberrima, intus thalassina, margine squamis ex cinereo albis vestita, valvis mediis anterius, nonnullis utrinque fusco maculatis. Linn. Gmel. p. 3205.

Sheil of eight valves, smooth, within sea green, margin covered with greenish white scales; middle valves on the fore part, and some of them on both sides spotted with brown.

Chem. Conch. 8. t. 95. f. 802.

The valves of this species are covered with numerous small brown spots, or stains, besides a band of a deeper colour, which runs on each side the dorsal ridge. Chemnitz figured this shell from a specimen in his own collection. It is rare, and its country unknown.

\section{COATED CHITON.}

Pl. 2. $f$. 1. Mr. Jennings.

10. Chiton tunicatus. Ch. testroctovalvi lavi, valvis albis, supra membranis suborbicularis, limbo coriaceo reflexo.

Shell of eight valves, smooth, valves white, above the membrane roundish, margin coriaceous and turned back.

This singular shell makes a very different appearance from any other species of the genus. The valves, instead of being wholly visible, are coated half way upwards with a black membrane, which is reflected from 
the coriaceous border, and fixed into a groove cut for that purpose round the upper part of each valve. The portion that is seen above the membrane, is roundish, uneven, and emarginate, of a sordid white, or flesh colour, and collectively resembling a row of dried beans. The remains of a thin cortical substance is to be seen on parts of the naked shell, which, independent of the coriaceous membrane, once covered the valves. The valves within side are quite exposed and perfectly white. The shell is an inch and a quarter broad, and when extended, four inches long. Mr. Humphrey once had a specimen from Copenhagen, but cannot say that it inhabits the North Seas.

\section{GIGANTIC CHITON.}

11. Chiton gigas. Ch. testa octovalvi crassa convexa alba, valva prima crenata, postrema dentata, mediis emarginatis. Linn. Gmel. p. 3206.

Shell of eight valves, thick, convex, and white : first valve indented, the last toothed, middile valves emarginate.

Chem. Conch. 8. t. 96. f. 819. Chem. Chit. t. 2. f. 10.

Encyclop. Method. pl. 161. f. 3.

Chiton albus. Barbut. pl. 1. f. 1.

The Gigantic Chiton exceeds four inches in length, and except the following species, is the largest of the genus. The valves have a very clumsy appearance, and seem to be rudely folded over each other. The margin is tumid, coriaceous, and of a black-brown colour. This Chiton inhabits the Cape of Good Hope.

Barbut has figured this shell by the name of albus. He says that the specimen was brought by Dr. Solander from the South Sea; probably, however, taken at the Cape, where it has been ascertained to live. The French have copied Chemnitz. 
KIDNEY SHAPED CHITON.

12. Chiton amiculatus. Ch. testa octovalvi reneformi fragilissima, corio extus scabro obducta. Linn. Gmel. p. 3206.

Shell of eight valves, kidney shaped and very brittle, covered externally with a rough coriaceous membrane.

Pallas, Nov. Act. Petr. 2. p. 241. t. \%. f. 26-30.

The kidney shaped valves is a striking peculiarity in this species, and more characteristic than the external covering, since the shape of the shell will remain when the membrane is gone.

Pallas says, that it inhabits the Kurile Islands, and is more than six inches long.

\section{CHESNUT CHITON.}

Pl. 2. $f$. 2, 3. Mr. Jennings.

13. Chiton castaneus. Ch. testa octovalvi glaberrima, supra castanea, intus rosea.

Shell of eight valves, very smooth, chesnut above, rose colour within.

Shell oval, valves perfectly smooth, except some faint indications of striæ, ruuning down the dorsal triangles towards the margin. Marginal triangles uniformly depressed near their insertion in the coriaceous border. Colour deep chesnut; where decorticated the shell appears white, and the marginal triangles and extreme valves, toothed at the base, and striated longitudinally. The valves within side the shell are of a fine rose colour, edged with white.

\section{Pl. 3. f. $2 \& 3$}

are the young of the same shell, which from its different size and colour, might readily be mistaken for a distinct species. At the apex of each valve, where the ridge of the shell is decorticated, there appears a small whitish 
spot, like enamel, and on the sides where the yellow coat is wanting, the white tonthed edges, and stria of the marginal triangles may be seen as in the old shell. The inside is variegated, but the rose colour predominates.

These interesting specimens are both in the possession of Mr. Jennings, who liberally allowed them to be figured. Their country is unknown.

\section{RED CHITON.}

14. Chiton ruber. Ch. testa octovalvi arcuata substriata corpore rubro. Linn. Syst. Nat. p. 1107.

Shell of eiglit valves, slightly striated, striæe varied; body red.

Chem. Conch. 8. t. 96. f. 813. Chem. Chiton. t. 2. f. 3. Encyclop. Method. pl. 161. f. 6.

This species is about an inch long, of an oblong form, with the back carinated, or keel shaped. 'It is generally of an uniform red colour, but sometimes there is a darker streak on the back, and where it becomes marbled with red and white, it forms the variety represented by Chemnitz, pl. 96. fig. 812.

It inhabits the North seas, and adheres to limpets.

\section{PUNCTURED CHITON.}

15. Chiton punctatus. Ch. testa octovalvi lavi, corpore punctis excavatis. Linn. Syst. Nat. p. 1107.

Shell of eight valves, body with hollow dots.

Chiton corpore punctato, testis octo. Aman. Acad. 3. p. 256. Seb. Mus. 3, t. 1. f. 132 .

This species is given on the authority of Linnæus, but is very indistinct. Two of the four references given by Linnæus have been rejected by Dr. Solander as incorrect. It is said to inhabit Asia, Europe, and America. 


\section{INDIAN CHITON.}

16. Chiton Indus. Ch. testa octovalvi ex cinereo albida, limbo squamoso, valvis mediis subtilissime punctatis Linn. Gmel. 1. p. 3205.

Shell of eight valves, whitish ash colour, margin scaly, middle valves very finely punctured.

Chiton Indicus. Chem. Conch. 8. t. 96. f. 811.

Inhabits the American ocean; is rather more than an inch long.

\section{GREEN CHITON.}

17. Chiton viridis. Ch. testa octovalvi, carinis triangularibus scaberrimis subdenticulatis, limbo squamulis minutissimis obsito seu obtecto. Chem. Conch. 10. pl, 173.

Shell of eight valves, keel triangular, rough, slightly toothed; margin covered with minute scales. Encyclop. Method.pl. 162. f. 9.

This shell is of a grass green colour, with a banded margin. This and No. 34, though distinct species, have been ranked by Gmelin as varieties of the C. squamosus.

\section{STRIPED CHITON.}

Pl. 2. f. 4; 5. Mr. JenNings.

18. Chiton lineatus. Ch. testa octovalvi lavi, valvis lineatis, limbo lato coriaceo.

Shell of eight smooth valves, valves streaked, margin broad and coriaceous.

The ground colour of this elegant shell is bright chesnut, with an interrupted white band running along the back ; undulating white lines, edged beneath with black, pass diagonally across the marginal triangles, and concentrically on the extreme valves. The white band on 
the back of the shell, which is occasionally interrupted with chesnut, terminates in a white triangular spot on the posterior valve. The back is convex, not carinated, and is delicately striated in the direction of the margin. The inside is whitish. Its country is unknown.

TUFTED CHITON.

Pl. 2. $f$. 6. Mrs. Mawe.

19. Chiton facicularis. Ch. testa octovalvi, corpore ad valvulas utrinque faciculato. Linn. Syst. Nat. p. 1106. Gmelin. p. 3202.

Shell of eight valves, body with a tuft of hair on each side of the valves. Chem. Conch. 10. t. 173. f. 1688. Encyclop. Method. t. 163. f. 15. Mont. Test. Br. p. 5. Suppl. pl. 27. f. 5. Linn. Trans. 8. p. 21. pl. 1.f. 1.

This shell is slightly keeled. The valves, on the upper part are cinereous marked with black; when magnified, they appear like shagreen : a hairy tuft proceeds from the lower portion of each valve, which is quite smooth, like horn, and of a yellowish colour; the margin is broad and coriaceous. The hairs frequently fall off when the shell is dried, and leave the marks only of insertion. This species is about an inch long and half as broad. Inhabits Barbary and is also found in the British seas, but of a smaller size.

\section{FURROWED CHITON.}

Pl. 3. f. 1. Mrs. Robinson.

20. Chiton sulcatus. Ch. testa octovalvi crassa convexa sulcata, limbo lato squamuloso.

Shell of eight valves thick, convex and sulcated, margin broad and scaly.

A thick shell deeply grooved in every part; the extreme valves are furrowed from centre to margin, and 
many of the corresponding ridges are also sulcated at the end: the middle valves are grooved in the same manner, and most of the marginal triangles are formed of three deep unequal furrows. The specimen from which our figure was taken, has but few scales remaining, but the impression of the rest is plainly visible. The colour sordid brown, inclining to black on the back part of the middle valves; inside greenish white; length, when extended, four inches ; breadth, an inch and a half.

This rugged shell is said to inhabit the South seas.

\section{BICOLORED CHITON.}

21. Chiton bicolor. Ch. testa octovalvi crassa dorsata, extus thalassina, intus nivea, margine nigra. Linn, Gmel. p. 3204.

Shell of eight valves, thick and ridged; outside sea-green; inside snowwhite, edged with black.

Chem. Conch. 8. t. 94. f. 794, 795.

The middle valves in this shell bend slightly upwards, the marginal triangles striated, the anterior valve marked with radiate striæ.

We have the authority of Chemnitz only for this species, who figured it from a specimen in his own cabinet. The uniform sea-green colour is a distinguishing characteristic. It is about two inches and a quarter long; its country unknown.

\section{CHERRY CHITON.}

22. Chiton cerasinus. Ch. testa octovalvi cerasina lavi; marginis dentibus niveis. Linn. Gmel. p. 3204.

Shell of eight cherry-coloured valves, smooth; marginal teeth snowwhite:

Chem. Conch. 8. t. 94. f. 796.

The shell is oval, about an inch and a half long, and of a dark cherry colour. Country unknown.

VOL. I. 


\section{MAGELLANIC CHITON. \\ Pl. 3. f. 6. DR. Соомв E.}

23. Chiton Magellanicus. Ch. testa octovalvi, crassa, ex fusco atra, supra convexa: fascia dorsi nigricante media, striis lateralibus favicantibus. Linn. Gmel. p. 3204.

Shell of eight valves, thick, black-brown; above convex, with a blackish band in the middle of the back and lateral yellowish strix.

Seb. Mus. 3. t. 1. f. 14, 15 ?

Chem. Conch. 8. t. 95. f. 797, 798. Chem. Chiton. pl. 2. f. 7. Encyclop. Method. pl. 160. f. 4, 5.

This species (when full grown) measures nearly two inches and a half in length; the ground colour of the shell is darkish brown; a black list runs along the middle of the back, with a yellowish-white lateral band on each side; the margin is broad, coriaceous, of a brown colour, and covered with minute whitish spines: inside, black in the middle, elsewhere greenish-white. The species varies somewhat in colour, and is apt to be much encrusted.

Inhabits the Straits of Magellan. The best representation of the shell is in a separate tract by Chemnitz, on Chitons.

\section{BROWN CHITON.}

24. Chiton fuscus. Ch. testa octovalvi fusca glaberrima, intus marginisque dentibus nivea, dorsi maculis trigonis nigris: utrinque fasciis obscure flavicantibus. Linn. Gmel. p. 3204.

Shell of eight valves, very smooth, the inside and marginal teeth snowwhite; back with triangular black spots, and faint yellowish bands on each side.

Chiton linter India orientalis. Chem. Conch. 8. t. 95. f. 799, 800 . Encyclop. Method. pl. 160. f. 6, 7.

This shell, externally, somewhat resembles the magellanicus; it is narrower, however, and has many mar- 
ginal teeth, the largest of which are on the two extreme valves : the back is also more raised, and is carinated, or keel-shaped. We are indebted to Chemnitz for the brown Chiton, among many others which he has added to the genus. It is a native of the East Indies.

\section{MEALY CHITON.}

25. Chiton minimus. Ch. testa octovalvi, glabra, nigra, hinc inde farinosa. Linn. Gmel. p. 3205.

Shell of eight valves, smooth, black, sprinkled with meal in patches.

Chem. Conch. 8. t. 96. f. 814.

This is a very small shell, about half an inch long, and is found in the Norwegian sea.

\section{BUG CHITON.}

26. Chiton cimex. Ch. testa octovalvi carinata diaphana fasciata; valva utraque extrema tenuissime punctata. Linn. Gmel. p. 3206.

Shell of eight valves, carinated, diaphanous, and banded; both extreme valves finely punctured.

Chem. Conch. 8. t. 96. f. 815.

A small species, about three quarters of an inch long; of a reddish-brown colour, fasicated longitudinally like the marbled Chiton. Inside marked with blackish bands on a ground of whitish ash-colour. Found with the preceding species.

\section{MILLEPEDE CHITON.}

27. Chiton asellus. Ch. testa octovalvi nigerrima, supra convexa, dorsi macula in singulis valvis flavicante. Linn. Gmel. p. 3206.

Shell of eight valves, deep black, with a yellowish spot on each of the valves.

Chem. Conch. 8. t. 96. f. 816. Encyclop. Method. pl. 161. f. 12.

The Chiton asellus is rather more than half an inch 
long, it is distinguished by the yellow spot on each valve. Inhabits the Northern seas, and adheres to the Mytilus modiolus.

\section{ICELAND CHITON.}

28. Chiton Icelandicus. Ch. testa octovalvi, subcylindrica, tenuissime punctata, nigra; limbo cinereo. Linn. Gmel. p. 3206.

Shell of eight valves, somewhat cylindrical, very finely punctured, black, margin cinereous.

Schröt. Conch. 3. p. 509. No. 19.

This small shell, which is narrow at each end, probably inhabits the North seas, since it adheres to the Venus islandica.

\section{WHITE CHITON.}

29. Chiton albus. Ch. testa octovalvi lavi, dorsata, corpore albo. Linn. Syst. Nai. p. 110\%. Gmel. 3204.

Shell of eight valves, smooth, slightly ridged; body white.

Chiton testa ociovalvi lavi, valvula prima postice emarginata. Mull. Zool. Dan. Prodr. 3019. Act. Nidros. 2. p. 54.

Chem. Conch. 8. t. 96. f. 817. Chem. Chiton. t. 2. f. 9. Mont. Test. Brit. p. 4. Linn. Trans. 8. p. 22. t. 1. f. 4 .

The first valve in this shell is notched on the hinder edge. The shell is smooth, of an oval shape, and about three-quarters of an inch long. It inhabits the Northern ocean.

It is found, about the size of a grain of wheat, on oysters and other shells on the coast of Great Britain. Dr. Pulteney mentions it from Poole, and says, that besides oyster shells, it is found on the Ulva intestinalis and latissima. 


\section{BORDERED CHITON.}

Pl. 3.f. 4.

30. Chiton marginatus. Ch. testa octovalvi, margine serrato rafiexo lavi. Linn. Gmel. p. 3206.

Shell of eight valves, smooth, with a serrated reflected margin.

Oscabrion Gallicum, Argenv. Conch. t. 25. f. M. Penn. Br. Zool. ed. 1812. 4. pl. 39. f. 2. Mont. Test. Brit. p. 1. Linn. Trans. 8. p. 21. t. 1. f. 2.

This shell is of a reddish-brown colour, and of an oblong shape. The valves are carinated and vary in colour. It is about the size of a millepede, and is found on several of the coasts of Great Britain, attached to oyster and other shells.

The $C$. septemvalvis described by Mr. Montagu, he is now inclined to refer to this shell as an accidental variety only, and not a distinct species.

\section{ASH-COLOURED CHITON.}

Pl. 3. f. 5.

31. Chiton cinereus. Ch. testa octovalvi lavi carinata, corpore rubicundo, limbo subciliato. Linn. Gmel. p. 3204. Fabr. Fn. Groenl. p. 423.

Shell of eight valves, smooth and carinated; body reddish, margin somewhat ciliated.

Testa octovalvi ovata. Linn. Syst. Nat. ed. 12. p. $110 \%$.

Born. Mus. Caes. t. 1. f. 3. Chem. Conch. 8. t. 96. f. 818. Encyclop. Method. pl. 161. f. 11. Mont. Test. Brit. p. 3. Linn. Trans. 8. p. 22. pl. 1. f. 3 .

The cinereous Chiton is of an oval shape, compressed and carinated, and from a quarter to three-quarters of an inch long. When the animal is alive the shell is reddish, but becomes grey after death. The valves on the back project into a beak, and, as the figure expresses, 
are sometimes tipped with white, so as to form a dorsal line: the margin is spotted.

Fabricius found this species among the roots of ulva on the Norway coast. It occurs, though not commonly, on the British shore, in Devonshire, at Weymouth, and at Poole, attached to rocks and oysters.

\section{SMOOTH CHITON.}

32. Chiton lavis. Ch. testa octovalvi glaberrima, dorso elevato. Linn.

Trans. 8. p. 21. Linn. Gmel. p. 3206.

Shell of eight valves, very smooth, with a raised back.

Penn. Br. Zool. ed. 1812. 4. pl. 39. f. 3. Mont. Test. Brit.p. 2.

This Chiton is of a reddish-brown colour, sometimes spotted with yellow, and often with a longitudinal line down the back : the margin broad and finely reticulated. It is the size of a wood-louse, and, according to Pennant, inhabits the shores of Loch Broom, in West Rothshire. Mr. Montagu has found it with the C. marginatus, in Salcomb Bay.

\section{* With Seven Valves. TUBERCULATED CHITON.}

33. Chiton tuberculatus. Ch. testa septemvalvi, corpore tuberculato. Linn. Syst. Nat. ed. 12. p. 1106.

Shell of seven valves, body tuberculated.

Chiton oscabrion. Mus. Ad. Fr. p. 96.

Chiton cylindricus. Schröter Conch. 3. p. 394. t.9. f. 19.

This species is of an oblong shape, covered with tubercles placed in a quincunx order, the sides cinereous mixed with white, and marked with brown waved bands: on the back, which is greenish, runs a broad black band, It inhabits South America. 


\section{TESSELLATED CHITON.}

34. Chiton tessellatus. Ch. testa septemvalvi striata, viridescente, corpore squamoso, dorso strigis albidis et nigricantibus distincto. Chem. Conch. 10. t. 173. f. 1690.

Shell of seven valves, striated, greenish, body scaly, back marked with black and white stripes.

Encyclop. Method. pl. 162. f. 10.

The extreme valves of this species, and the marginal triangles of the middle valves, are so striated as exactly to resemble mosaic work ; the trivial name of tessellated, therefore, suggested by Dr. Leach, is very appropriate. The back of the shell is bistre, the tessellated parts verdigrease green, the margin scaly, with green and white bands.

\section{HAIRY CHITON.}

35. Chiton crinitus. Ch. testa septemvalvi, pilis brevibus dense obsita. Linn. Gmel. p. 3206.

Shell of seven valves, thickly covered with short hairs.

Penn. Br. Zool. ed. 1812. 4. p. 142. pl. 39. f. 1. A.1. Encyclop. Method. pl. 163. f. 13. 14. Mont. Test. Brit. p. 4. Linn. Trans. 8. p. 20.

We have Pennant's authority only for the existence of this species, which is extremely rare. Mr. Boys is said to have found it at Sandwich, but from the long and close habits of intimacy which the author enjoyed with that gentleman, he can safely state that the shell was not in his possession. Mr. Pennant says that it inhabits the sea, near Aberdeen, and is five-eighths of an inch long. The figures in the French Encyclopedia are copied from Pennant. 


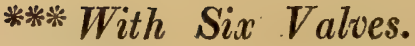

\section{HISPID CHITON.}

36. Chiton hispidus. Ch. testa sexvalvi striata. Linn. Syst. Nat. 1. p. 1106. Gmel. 3202.

Shell of six valves striated.

Schröter Conch. 3. p. 493. t. 9. f. 8.

This species is about the size of a filbert, of a blackish grey colour, speckled with white, and very finely marked with minute granulated striæ.

Inhabits America.

\section{SEA-GREEN CHITON.}

37. Chiton thalassinus. Ch. sexvalvi glabra ovali thalassina, supra linea media dilutiori, limbo tenui hyalino. Linn. Gmel. p. 3206.

Shell of six valves, smooth, oval, sea green, with a paler yellow line along the back; margin thin and hyaline.

Schröter Einl. in Conch. 3. p. 509. No. $18 . \longrightarrow$ Litterat. 4. p. 4. t.1. f. 1.

Described only by Schröter. It is rather convex, and about half an inch long: its native country unknown, 


\section{Genus 2.}

\section{E P A S.}

\section{GENERIC CHARACTER.}

\section{Animal Triton.}

Testa basi affixa multivalvis : valvis inæqualibus erectis.

Ánimal ä Triton.

Shell of many valves, fixed at the base: valves unequal and erect.

\section{GENERAL OBSERVATIONS.}

Some late authors of repute, both abroad and in this country, struck with the difference of appearance between the conical and compressed shells of this genus, have separated the species, and formed them into distinct "genera. It has been already stated, that it is not intended in this work to deviate from the Linnæan order; and this determination arises not only from a conviction of its superior utility, but also from a desire to oppose, in some measure, the great inclination which has appeared of late on the Continent to multiply genera; more it is to be feared in some cases to the confusion and prejudice, than the elucidation and advancement, of Natural History. This, however, is no reason why the opinions of other authors should not be regarded; and therefore we shall notice how far they are justified in their proceeding, with respect to the present genus, by considering the following grounds of separation as proposed by Bruguiere. 
The compressed shells, or barnacles, are generally composed of five valves, not articulated, but merely connected together by a membrane which bounds their circumference. These valves are supported on a flexible pedicle, which the animal can lengthen and contract, or move in any direction at pleasure.

The conical, or acorn shells, on the contrary, are generally composed of six valves, which form a kind of pyramidal tube, having all its parts strongly articulated, or joined to each other by delicate sutures. The base is solid and testaceous, by which they firmly fix themselves to other bodies. There are four valves on the top of the shell which form an operculum, or lid; these valves open or close, according as the animal protrudes its body, or shrinks within its shell. These appendages are entirely wanting in the compressed shells; nor have they any thing to correspond with them, unless their five great valves may be considered as the operculum, and the ligament to which they are attached, as the base corresponding to that of the acorn shell.

The essential differences, therefore, of these two divisions of shells, or genera, as they are constituted by Bruguiere, consists, -

1st. In their support, which is testaceous in the conical, and membranous in the compressed shells.

2nd. In the structure of the shell, which is composed of articulated pieces in one kind, while the valves of the other division are connected by membrane only.

3rd. In the operculum, with which the conical shells are exclusively provided.

These reasons, it must be confessed, are strongly in 
favour of a generic distinction; but, nevertheless, the opinion of Dr. Maton, expressed in the eighth vol. of the Linnæan Transactions, that the gradation from the conic to the compressed species, appears so natural, as not to admit of their being separated withount violation of the general principles of the system, must not be disregarded. The Doctor refers to the Lepas mitella, as the link which beautifully unites these two divisions, and adds that " even if a difference in the contained animal should be objected, we cannot agree in that particular being made a ground of distinction, since it is not the exclusive consideration on which Linnæus professes to found his arrangement."

The conical shells, or acorns, are found attached to a variety of substances. The common species is frequently abundant on lobsters, oysters, \&c. ; and many kinds arrive in England, fixed to the bottom of vessels from foreign countries. Different individuals of the same species, are subject to vary greatly in their external form. This is owing entirely to their manner of growth: the eggs are hardly excluded from the animal, before they become fixed to some neighbouring body; sometimes to the parent shell, or to the support on which that rests, or to rocks, \&c. When these eggs are deposited in groups, the shells, as they increase in size, are constrained for want of room, and they consequently become misshapen and irregular, in proportion as this inconvenience prevails. This compression so influences their external organization, that the conical tube often loses its natural appearance, and assumes angles that would not otherwise exist.

The conical shell, although it appears to consist of a single piece, is generally, as has been already observed, 
composed of six triangular portions, or valves; these are separate at top, but joined at bottom, and have their intervals filled with shell of the same naiure, but of a different texture. The valves are joined by parallel laminæ, or plates, which project from the edge, and, closing over each other, connect these parts together; and form as it were a single shell. In very young shells the cone appears on all sides smooth and even; but as the animal within increases in size, it presses against the walls of its habitation, and thus gradually opens the sutures and enlarges the cavity. It is this separation which gives to the valves their triangular appearance, and which may be readily observed in the old shells of the common species, so abundant on the backs of oysters; \&c. According to Bruguiere, the upper part of the shell never increases; it remains always the same as : when first formed, and the augmentation of the diameter of the opening, is the result only of the successive developement of the lateral edges.

The operculum, or lid, which is seen on the top of the cone, is always proportioned to the diameter of the opening which it is designed to close. It increases with the rest of the shell by a juxtaposition of testaceous matter, which takes place on the inferior edges of the pieces, or valves, of which it is composed. These valves: are articulated together by a cruciform suture, and fixed against the interior of the shell by a circular ligament which admits of sufficient motion for the animal to raise the lid and extend its tentacula. These tentacula, when in the water, are continually moving in a spiral direction, so as to bring the food, whatever it may consist of, within the vortex produced by their motion.

The compressed shells, or barnacles, are often found in 
groups, adhering by their flexible stems, to shipping, or floating pieces of wood. They seem to delight in situations exposed to the strong motion of the waves, and therefore often place themselves near the rudder of the ship, where the agitation of the water is most considerable. The singular animal which these shells contain, and which differs in nothing essential from that of the conical shells, is : furnished with a plumose fringe, divided into twenty-six filaments, or tentacula, of different lengths: the shortest are situated on each side of the mouth, and do not appear on the outside of the shell. Each filament is articulated throughout its length; and from each joint proceeds a bunch of very delicate hairs. These tentacula, or feelers, are supported, two by two, on fleshy pedicles. The flexible trunk with which this animal is provided, is rather longer than the tentacula; and the mouth, which is placed immediately below it, is of an oval shape, and closed by a scaly operculum. The digestive organs are represented in the Lectures on Comparative Anatomy, by Sir Everard Home, vol. 2. pl. 75.

We are not acquainted with the nature of the nourishment by which these animals are sustained; but it probably consists of such minute worms, and sea insects, as come within the reach of their feelers, for those parts are kept very actively employed while the animal is in search of food.

We have no particular observations on the mode by which these flat shells increase in size; but if we may judge from inspection, it appears that their ligaments separate, and that the enlargement takes place from the curved edge of the valves. New shelly matter may there be deposited from time to time, till the animal has attained its full growth; and in this case the extremities 
of the shell, that is, the summit of the small valves, and the lower angle of the large, will be the oldest parts. The thin curved valve in front, will at the same time be augmented laterally.

The name of Lepas which Linnæus has adopted for this genus, was given by the ancients to the Patella, or limpet. Aristotle, from the resemblance which some of them bear to acorns, has very properly called them Báravou; and Athenæus tells us that, when large, they are easily digested, and of an agreeable taste.

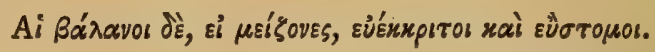

Athen. L. 3. c. 11. p. 88.

Balani nigri et albi, are mentioned among the dishes served up at the famous supper of Lucullus; and the Chinese at this day are said to be fond of the Bell acorn, Lepas tintinabulum, which, when boiled, is not in taste unlike the lobster. 
* With Cylindrical Shells.

WINDPIPE SHELL.

Pl. 4*. fig. 1, 2, 3. Dr. Соомв .

1. Lepas Tracheæformis. L. testa tubulosa, striata, utrinque truncata ; costis transversis crebris: operculo quadrivalvi.

Shell tubular, striated, truncated at both ends; closely ribbed transversely: operculum of four valves.

Tubicinella. Lamark Ann. du Mus. D'Hist. Nat. 1. p. 461. pl. 30. f. 1, 2 .

This singular shell consists of a cylindrical tube somewhat bent, and narrowing a little towards the base. It is open at bottom, but the top is closed by an operculum of four smooth valves, surrounded by a fleshy collar, which connects it with the shell: both ends are orbicular, and the sides are divided into six compartments, or valves, by as many smooth and narrow bands. The ribs on the outside of the shell are very strong, and have sometimes smaller ones between them. The shell is of a cellular substance, regularly striated longitudinally. It is of a tawny colour, with a white inside.

We are indebted to Lamark for an account of this shell, which he published in the Annales du Museum D'Histoire Naturelle, and has described it as a new genus, by the name of Tubicinella. That it is clearly a multivalve composed of six uniform portions, and not a univalve shell, as stated in his generic character, will be immediately perceived upon inspection; we have therefore removed it to its proper situation, and placed it at the head of a genus to which it strictly belongs.

Lamark notices two shells which he thinks may be varieties of each other, but is willing at the same time to distinguish them specifically, by the names of major 
and minor. They in fact differ merely in the situation of the rings, which in some shells, as fig. 3 , are farther apart than in others, and the shell is occasionally somewhat larger.

These curious productions inhabit the back of the South Sea -whale, where they bury themselves in the skin and fat. Dufresne, in a memoir which is a continuation of that of Lamark, observes that the animal, independent of its other parts, is furnished with a collar lightly striated, which secretes the testaceous matter for the formation of the rings. This collar, always remains visible between the sides of the shell and the operculum, see fig. 1. In proportion as new rings are formed, the animal buries its shell deeper in the fat of the whale, insomuch that two rings are all that are at any time visible above the skin; the rest of the shell being firmly secured in its situation by the help of its annulated surface. The animal when it projects above the operculum shows a fleshy neck, through which proceed the tentacula. This neck is seen in fig. 2. These shells are generally about an inch long, but as their growth is progressive, depending upon their age, they have been found of three times the usual length. A group of them is represented at fig. 2, to show their natural situation in the whale.

The fine specimens of this shell, for which the author is indebted to Dr. Coombe, were not procured till after plate 4 was printed: it has therefore been necessary to distinguish this plate by an asterisk, as it must be placed, in order, at the head of the genus. 


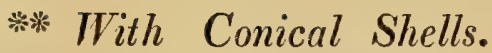

TURBAN ACORN.

Pl. 4. Mrs. Robinson.

2. Lepas Diadema. L. testa subconica, lobis sex elevatis quadripartitis, operculo membranaceo bidentato. Mull. Zool. Dan. p. 550. No. 3024. Linn. Gmel. p. 3208. Fabric. Fr. Groenl. p. 425.

Shell subconic, with six raised four-parted valves; operculum membranaceous and bidentate.

Testa subrotunda, sexlobata, sulcata. Linn. Syst. Nat. ed. 12. p. 1108.

Balanus, testa subcylindrica, valvulis longitudinaliter sulcatis, costis decussatis, radiis transversè striatis. Brug. Encycl. Meth. Hist. Nat. tom. 6. p. 171.

Peḋiculus ceti. Ellis, Phil. Trans. vol. 50. t. 34. f. 7.

Lister, Conch. t. 445. f. 288. Gualt. Test. t. 106. f. Q. Walch. Naturf. 8. t. 4. f. a. b. c. Born, Mus. Ces. Test. t. 1. f. 5, 6. Da Costa, Brit. Conch. p. 251. t. 17. f. 2. Encycl. Method. pl. 165. f. 13, 14. Donov. Br. Shells. t: 56. f. 1, 2. Mont. Test. Brit. p. 13. Linn. Trans. 8. p. 27.

The Lepas Diadema is composed of six valves, which, with their intermediate spaces, divide the shell into twelve, unequal, triangular compartments. Six of these divisions are formed of strong longitudinal ribs, from four to six in number, which diverge from the apex towards the base of the shell, and are striated transversely. The other compartments, though they have a polished surface, are finely striated. The interior is funnel-shaped, being much wider at top than at bottom; it exhibits six divisions, formed by as many bands, which correspond with the external valves. The bottom is divided into eighteen striated partitions, which project a little within the opening of the shell, and are finely toothed, for the purpose of adhering more firmly to the back of the whale. These divisions are generally 
filled with the black skin of the animal, as may be seen in the lower figure of pl. 4.

The operculum, as Muller and Fabricius have observed, is membranous, and terminates in two teeth, or small valves. The shell is of a dirty white colour, with sometimes a greenish tinge, and the bands within side are darker than the rest of the body. Large shells of this species are an inch and a half high, and two inches wide at the base. They are found in the North seas, adhering firmly to the whale, and their general situation is in the furrows of the skin above the base of the pectoral fins. It is often found on the shores of Scotland, but very rarely in the southern parts of this kingdom.

The eared barnacles, Lepas aurita, which Ellis has figured on the top of this species, have led some authors to suppose that the animal resembles a cluster of small hooded serpents, issuing from the aperture and openings on the ribs of the shell. A little attention to circumstances would have prevented this mistake, since the small openings which appear on the upper surface of the valves in defective turban shells, have no communication with the inner chamber, and are very insufficient for the passage of so large a body as Ellis has represented.

Plate 4 represents the perfect shell; the top figure is a side view, the middle shows the interior, and the lower figure the base of the shell, or that part which adheres to the skin of the whale. Chemnitz has figured the perfect shell correctly. Born's figure is also good, but Gualtieri has not been so successful. Lister, Klein, Da Costa, and Donovan, have figured worn shells, that is, with the ends of the valves open at top, and showing the three cells within. 
Muller's definition of the $\boldsymbol{L}$. Diadema is perfectly correct, except that the word subcylindrica would have been more appropriate than subconica.

\author{
WHALE ACORN.
}

Pl. 5. f. 1, 2, 3. Dr. Сооме E.

3. Lepas balænaris. L. testa subconica, valvulis sex elevatis, longitudinaliter sulcatis.

Shell somewhat conic, with six raised valves, grooved longitudinally.

Wrinkled star cake. Petiv. Amb. Icon. t. 1. f. 11.

Rumph. Mus. t. 14. f. H. Walch. Naturg. 10. t. 1. f. 11, 12. Chem.

Conch. 8. t. 99. f. 845, 846.

Shell of six valves, grooved longitudinally and striated transversely: intermediate spaces showing the connecting sutures on one side, and ending in a point at the base of the shell. Valves grooved regularly in young shells, but often distorted in old ones. Height about an inch, aperture at top half an inch, diameter across the bottom one inch and three quarters.

This shell is evidently a distinct species, and not, as has been supposed, a variety only of the preceding. It has a much smaller opening; the interior is not funnelshaped; the valves in full-grown shells, are not so prominent; the intermediate spaces are narrower, and the six divisions which correspond with them beneath, are ramified, as expressed in fig. 3. The specimen of the Lepas balanaris represented by Dufresne, in the first vol. of the Annales du Museum d'Histoire Naturelle, if intended for a young shell, is too convex; if for an old one, too regular. He professes to have acquired his knowledge of this species from Hunter's Museum, where he says, that many of these shells are sunk in the 
fat of the whale, and preserved in spirits. That there are twenty-five of the $\boldsymbol{L}$. Diadema in this situation, is certainly true ; but in what part of the Museum he perceived the $\boldsymbol{L}$. balanaris grouped in a similar manner, we are at a loss to discover.

Dufresne's figure has a quadrivalve operculum, surrounded by a ligament which connects it with the shell. If this be correct, (and he tells us he furnished the artist with a shell for the purpose,) it will at once mark the distinction between this and the preceding species, which has an operculum of two small valves only, surrounded by membrane.

The $\boldsymbol{L}$. balanaris buries itself to a certain depth in the skin of the whale, and when the shell is separated from the animal, it will be partly covered with a portion of the skin, which gives it a black and resinous appearance. It may, however, be readily cleaned of this matter; but the line of separation always remains visible, and may be seen in figure 1 and 2, encircling the shell towards the upper part.

The dissimilarity in appearance between fig. 1 and 2 , may possibly lead to the supposition that they are distinct species, but it is age alone which makes the alteration, fig. 2 being a young shell. 
TURTLE ACORN.

$P l$. 5. f. 4. Mrs. RoBinson.

4. Lepas testudinaria. L. testa plano-convexa radiis sex excavatis striatis. Linn. Syst. Nat. p. 1108. Linn. Gmel. p. 3209.

Shell plano-convex, with six hollow, striated, rays.

Lepas testudinaria, testa suborbiculari, plano-convexa lavi, intus lamellis serrulatis, areis excavatis transversè sulcatis. Born, Mus. Cres. p. 5. -ejusd. Testac. Mus. Cas. p. 10.

Balanus ovatus, subdepresso conicus, sulcis sextriquetris excavatis, supernè stellatis. Gron. Zooph. Fasc. 3. p. 257.

Verruca testudinaria. Rumph. Mus. t. 40. f. K.

Ellis, Phil. Trans. vol. 50. t. 34. f. 12. Gault. Test. t. 106. f. M. N. O.

Knorr. Vergn. 3. t. 30. f. 3, 4. Favanne, t. 59. f. A.4. A. 5. Chem.

Conch. 8. t. 99. f. 847, 848. Encyclop. Method. pl. 165. f. 15, 16.

This shell is of an oval shape, and convex; the surface is white, smooth, and composed of six uniform triangular valves, which are separated from each other by as many excavated rays; these rays are striated transversely, and sometimes grooved in the same direction. The opening in the upper surface of the shell is oval, and partly closed by a quadrivalve, convex operculum, connected by ligament. The shell beneath, in its recent state, according to Plancus, has a coriaceous membrane, which supplies the place of the testaceous base, with which the conical species are, for the most part, provided. This membrane is never preserved in cabinet specimens. The opening of the shell beneath is much larger than above, and the thick walls are formed of numerous vertical laminæ, radiating from the centre towards the circumference. These laminæ are striated on both sides, and finely serrated on the edge. The specimen figured in pl. 5, is a young shell, and is therefore without those indentations on the edges of the excavated rays, which occur in those of more advanced age. 
There is something very singular in the locality of particular shells. The $\boldsymbol{L}$. testudinaria is found only on the turtle; it is not known on the whale, though it is by no means confined to particular seas. It is said to be common on the backs of turtles in the Mediterranean. Petiver mentions it on those of the Isle of Ascension, and Rumphius on the turtles of the southern coasts of Amboina. The $\boldsymbol{L}$. diadema, on the contrary, confines itself to the whale; it is never seen in any other situation, though it might with equal ease take up its abode elsewhere. Again, the $\boldsymbol{L}$. testudinaria is careful to fix itself on the most convex part of the turtle-shell, where it can remain in security, beyond the reach of the animal's fins. These habits, which are independent of all instruction, can be referred only to that instinct which pervades every part of animated nature, and which seems to be impressed upon the constitution of even the most insignificant being.

\section{BELL ACORN.}

Pl. 6. f. 1, 2. Mr. SOWERBY.

5. Lepas tintinnabulum. L. testa conica obtusa rugosa. Linn. Syst: Nat. ed. 12. p. 1108. Linn. Gmel. p. 3208.

Shell conic, obtuse, and rugged.

Balanus, testa purpurascenti gibba, longitudinaliter striata, operculo postice rostrato, radiis transversè striatis. Brug. Encycl. Meth. Hist. Nat. tom. 6. p. 165.

Lepas tulipa, testa subcubica lavi, operculis acutis transversim striatis. Mull. Zool. Dan. p. 251.

Lister, Conch. t. 443. f. 385. Ellis, Phil. Trans. vol.50. t. 34. f. 8, 9. D'Argenv. Conch. t. 26. f. A. B. Favanne, t. 59. A. Hutch. Dorset. p. 25. t. 1. f. 5. Chem. Conch. 8. t. 97. f. 828-831. Donov. Br. Shells. t. 148. Mont. Test. Brit. p. 10. Linn. Trans. 8. p. 25. $\beta$. Tulipa alba. Chem. Conch. 8. t. 98. f. 832.

This shell is composed of six unequal valves con- 
nected together, as usual, by a scaly suture, the edges of which appear finely crenated in the interior of the shell. The opening is large, and nearly triangular. The operculum consists of four valves, two of which are very large, and marked with projecting transverse striæ. A longitudinal furrow divides them from each other, and they are terminated by two conical prolongations, with sharp points, which form the other valves. The exterior of the shell is a cone, divided into six raised and six depressed compartments; the raised divisions are rough, and striated longitudinally; the depressed divisions are smooth and finely striated transversely. The shell is found of various sizes, from half an inch to three inches in height, and with a base in proportion; the colour is purple or violet, varied with brown, or reddish, as in fig. 2.

The bell acorn is found in groups on rocks, or on large shells, where more than fifty have been found united in a single cluster. They have been observed in the European ocean, on the coast of Denmark, in the Indian seas, and on the coasts of Amboina and Jamaica. They are often attached in such abundance to the bottoms of vessels from foreign countries, that many hundreds have been taken from a single ship.

It is strange, that this Lepas still continues to be admitted into the catalogue of British shells, since it is evidently an inhabitant of warm climates, and brought to us only by accident. It is never found alive upon the English coast, and we therefore cannot with propriety naturalize the species. No one thinks of calling a Chinese an Englishman because he often visits our country; and yet the only difference, in this particular, 
between the shell and the man, is that one is a passenger on the outside of the vessel, and the other within.

The figure given by Chemnitz under the name of Tulipa alba, is merely a white variety of this shell. It is remarkable for its size, which is very considerable, but differs in no other respect. This white variety has been dredged up in the neighbourhood of the Feroe Islands, at the depth of forty fathoms. The want of colour is probably owing to its situation in the deep, for why should not the colour of shells, like that of plants, depend on the influence of the rays of light? Those which are naturally coloured, may lose much of their beauty when they grow at too great a depth, and become quite white when they are wholly beyond the reach of the solar rays.

The figures of this shell by Gualtieri are very indifferent.

Gmelin's L. tulipa, p. 3209, No. 9, and $L$. cylindrica, p. 3213 , No. 25 , are repetitions of this species.

SCOTTISH ACORN.

Pl. 6. $f$. 3. Mr. Sow ERBY.

6. Lepas Scotica. L. testa sexvalvi, conica; valvulis longitudinaliter costatis.

Shell conic, of six valves; valves ribbed longitudinally.

This species, which was found in Scotland fixed to the Mytilus Modiolus, has six raised unequal, triangular valves, ribbed longitudinally, and striated at the base transversely. The operculum resembles that of the $\boldsymbol{L}$. Tintinabulum. The shell is of a sordid white colour, tending to greenish. 
WRINKLED ACORN.

Pl. 6. f. 4. Dr. Coombe.

\%. Lepas rugosa. L. testa subcylindrica, operculis acutissimis. Linn. Trans. 8. p. 25. t. 1. f. 5.

Shell somewhat cylindrieal; operculum very sharp-pointed.

Lepas borealis. Donov. Br. Shells, t. 160.

Balanus rugosus. Pultn. in Hutch. Dorset. p. 25. t. 2. f. 10. Mont. Test. Brit. p. 8.

This shell has six triangular valves, so far separated at top as to leave the aperture almost as wide as the base. The aperture is of a rhomboidal shape, with the inside margin ridged transversely. The valves within are strongly grooved longitudinally. The shell externally is nearly smooth, and of a whitish colour lightly stained with purple.

The specimen figured in pl. 6 is foreign; but it is described as a British shell by Mr. Montagu, who found it with irregular compartments, wrinkled or striated longitudinally. The operculum has four rough angulated valves, terminating in four distinct points, inclining backwards.

\section{NARROW-MOUTHED ACORN.}

Pl. 6. $f$. 5. Mrs. Mawe.

8. Lepas angustata. L. testa elongata lavi sexvalvi, apertura angusta, operculo minimo. Linn. Syst. Nat. Gmel. p. 3212.

Shell elongated, smooth, of six valves; the aperture narrow; operculum very small.

Balanus perforatus, B. testa semi-ovata, longitudinaliter striata, violacea, apertura coarctata minima, radiis filiformibus. Brug. Encyclop. Method. Hist. Nat. tom. 6. p. 167.

Lepas ore angustiore, apertura coarctata. Chem. Conch. 8. t. 98. f. 835. Encyclop. Method. pl. 164. f. 12.

This shell is of a very conical shape, owing to the 
valves being united at top, and not separated, as usual, by a broad triangular compartment. A narrow line is all that distinguishes the divisions of the valves. The shell is striped with violet, and often tipped with a deeper tint of the same colour. The opening is very small. The operculum is of four valves striated transversely; the two posterior valves are pointed.

This Lepas is found in very considerable clusters, fixed on other shells. It occurs in the Mediterranean, on the coast of Barbary, and, according to Bruguiere, on the coast of Senegal.

\section{CONIC ACORN.}

9. Lepas conoides. L. testa conica lavi, valvulis acuminatis, apertura angustissima. Donov. Br. Shells, pl.30, f. 3.

Shell conic, smooth, the valves pointed, aperture very small.

Mont. Test. Brit. p. 12. Linn. Trans. 8. p. 24.

The $\boldsymbol{L}$. conoides, as figured by Donovan, is very like the preceding species, but may be distinguished by its transverse striæ, which are wanting in the $L$. angustata. The shell is of a violet colour, and the valves are but slightly separated at top. It is an English species, and was discovered by Mr. Bryer, of Weymouth, adhering to the $L$. anatifera. 
COMMON ACORN.

Pl. 7. $f$. 3.

10. Lepas Balanus. L. testa conica sulcata, operculis acuminatis. Linn. Syst. Nat. ed. 12. p. 1107. Linn. Gmel. 1. p. 3207.

Shell conic and grooved: operculum sharp pointed.

Balanus sulcatus. B. testa conica truncata longitudinaliter sulcata, radiis transversè striatis. Brug. Encycl. Meth. Hist. Nat. tom. 6. p. 163 .

Lister, An. Ang. t. 5. f. 41 . Ellis, Phil. Trans, vol. 50. t. 34. f. 17. Penn. Brit. Zool. ed. 1812. t. 40. f. 1. Chem. Conch. 8. t. 97. f. 820. Da Costa, Brit. Conch. p. 249. Donov. Brit. Shells, t. 30. f. 1. Mont. Test. Brit.p. 6.

Shell of six valves, rugged at the edges : aperture not large in proportion to the shell, which spreads much at the base. Valves striated, sometimes sulcated longitudinally. Operculum of four pointed valves, the two smallest projecting beyond the others, which are transversely striated, and divided by a longitudinal furrow. Colour white, or greenish, or cinereous brown. Size various, from a pea to a filbert.

This species is found in clusters adhering to the rocks on the coasts of Great Britain. It is common also on the Greenland shore, and in the Mediterranean; and will probably be met with on the rocky coasts of most parts of the world. It has often been confounded with the following species, from which however it is sufficiently distinct.

Pennant's fig. 3, of pl. 40. ed. 1812, is a variety only of this shell. 
SMOOTH ACORN.

Pl. 7. f. 1.

11. Lepas balanoides. L. testa conica truncata lavi, operculis obtusis. Linn. Syst. Nat.p. 1108. Linn. Gmel. p. 3207.

Shell conical, truncated, smooth : operculum obtuse.

Balanus, testa subcylindrica lavigata; apertura dilatata; radiis insculptis lavibus. Brug. Encyclop. Method. Hist. Nat. tom. 6. p. 164. Lister, Conch. t. 444. f. 287. Chem. Conch. 8. t. 97. f. 826. and 98. f. 833. Penn. Brit. Zool. ed. 1812. 4. t. 40. f. 2. Da Costa, Brit. Conch. p. 248. t. 17. f. 7. Donov. Br. Shells, t. 36. f. 2, 3. Mont. Test. Brit. p. 7. Linn. Trans. 8. p. 24.

A much smoother shell than the preceding: the compartments divided by a longitudinal furrow; and the valves sometimes deeply sulcated at the base: points of the valves generally directed one way, and ending in a beak. Operculum of four valves, the two upper of which are slightly striated, transversely, the others are quite smooth. Colour whitish. Size, at the base, from one quarter to three quarters of an inch; height, from a quarter to half an inch.

This is a very common shell on rocky coasts, and is found in abundance adhering to almost every fixed substance between high and low water mark. It occurs generally in clusters, and is frequent on oyster and other shells, and on the back of lobsters. It inhabits Europe, America, and India; and, if looked for, will most probably be found also on the coast of Africa.

The shell represented by Chemnitz, in vol. 8. pl. 97. f. 824. is a remarkable variety of the $L$. balanoides, The author has a specimen nearly like it, seated on the back of the Nerita Catena, but it has not quite so much of the tulip shape. 
CLUB-SHAPED ACORN.

Pl. 7. $f$. 2. Mr. Sow ERBY.

12. Lepas clavata. L. testa clavata elongata; operculis obtusis. Shell club-shaped, elongated; operculum obtuse.

Lepas elongata. L. testa cylindrica nivea, pellucida sexvalvi supra fissa; operculo obtuso sulcato transversim striato. Linn. Gmel. p. 3203.

Balanus fistulosus. B. testa tubulosa elongata striata, valvulis supernè dehiscentibus, apertura patula. Brug. Encycl. Meth. Hist. Nat. tom. 6. p. 166.

Penn. Brit. Zool. ed. 1812. 4. t. 40. f. 4. Chem. Conch. 8. t. 98. f. 838. Schröter der Berl. Naturf. 5. t. 5. f. 2. Journ. 4. t. 2. f. 2. Encyclop. Method. pl. 164. f. 7, 8. Linn. Trans. 8. p. 26.

Balanus clavatus. Ellis, Zooph. p. 198. t. 15. f. 7, 8. Mont. Test. Brit.p. 10.

A tubular club-shaped shell, from one inch, to two and a half, or three inches long. The exterior is striated, rough, and sometimes tuberculated. The aperture is large, and divided into six parts, by as many unequal valves, three of which are wider than the others. The operculum is composed of four valves obliquely striated. The colour of the shell is white, sometimes greenish.

This species bears a very strong resemblance to the L. balanoides, when that shell happens to be elongated, as it is occasionally found. See Donovan, pl. 36. f. 3. It is often observed in large clusters so wedged together that the summits only of the shells can be distinguished. It inhabits Iceland, and the northern parts of Europe; was brought from Newfoundland by Sir Joseph Banks; and has been taken by dredging in the sea at Weymouth, but is by no means a common shell on the British coasts. 


\section{PUNCTURED ACORN.}

13. Lepas puuctata. L. testa conica, truncata punctata; operculis obtusis. Linn. Trans. 8. p. 24.

Shell conical, truncated, and punctured; operculum obtuse.

Balanus punctatus. Pulln. in Hutch. Dorset. p. 25. t. 1. f. 10 . Mont. Test. Brit. p. 8. t. 1. f. 5.

This is described by Mr. Montagu as a distinct species, that may be readily known by its dull brown colour, by its rugose appearance, and especially by the operculum, which is punctured like a thimble. He observed it in abundance on the south coast of Devonshire, clustered on the Patella vulgata, and on the rocks near high water mark. Dr. Pulteney, who doubts its specific distinction, says that it differs from the large and most perfect specimens of the common acorn only by being punctured like a thimble.

The L. cornubiensis, of Pennant, is probably this shell.

\section{RIBBED ACORN.}

14. Lepas costata. L. testa subconica; operculis acutis. Donov. Br. Shells. t. 30. f. 2.

Shell somewhat conic: operculum sharp pointed.

Mont. Test. Brit. p. 11. Linn. Trans. 8. p. 24.

A very pretty species of a white colour, and about half an inch in diameter. The valves are indistinct. It has elevated ribs diverging regularly from the aperture to the base, and was discovered by the late Mr. Adams, adhering to some pieces of broken rock on the coast of Pembrokeshire. 
SPONGE ACORN.

15. Lepas spongiosa. L. testa sexvalvi, conica; valvulis acuminatis, spinosis.

Shell of six valves, conic; valves sharp pointed and spiny.

Mont:Test. Brit. Suppl.p. 2. pl. 17. f. 4, 5, 6.

We are indebted to Mr. Montagu for the knowledge of this curious species of Lepas. It has six wrinkled, spiny, sharp-pointed valves, the three anterior of which are broader and shorter than the others. The base of the shell is flat and concentrically wrinkled. There is a singular appendage to this base, which is unknown in any other species of the genus. It is a little cup, rounded at the bottom, and fixed by a ligament to the circumference of the base. This cup is hollow within, and, according to Mr. Montagu, exactly resembles the Patella antiquata inverted. It is an appendage independent of the rest of the shell, with which it has no communication internally. The operculum has four valves, the anterior pair rough with decussated striæ, the posterior pair longer and a little hooked forward. The colour is livid-brown with a purple tint towards the point of the summit.

Inhabits a particular species of sponge, in which it is found so inclosed that no part of the shell is visible, except the points of the operculum. Several of this species were found by Mr. Bryer of Weymouth, in Portland reach. 
HELMET ACORN.

16. Lepas galeata. L. testa galeato apertura laterali. Linn. Gmel. p. 3209.

Shell helmet-shaped, with a lateral aperture.

Balanus, testa obliquata conica, basi subinfundibuliformi superne marginata, apertura laterali. Brug. Encyl. Meth. Hist. Nat. tom. 6 p. 170.

Lepas calceolus. Pal. Zooph. p. 198. Schröter Einl. in die Conch. 3. p. 318. N. 7. t. 9. f. 20. a. b. Encyclop. Method. pl. 165. f. 7, 8.

This shell is of a very singular shape. It appears to be composed of two oblique cones with their bases resting upon each other, but does not bear much resemblance either to a helmet or a slipper. The base by which it fixes itself is hollow, and the edges are sharply carinated. It has six unequal valves; the three anterior are the largest and situated obliquely, the others are perpendicular, and much shorter: the aperture is placed behind, and has a striated operculum of four valves. The upper part of the shell has a tendency to violet colour, the base is cinereous.

This species seems to attach itself particularly to corallines. Pallas found it on the stems of the Gorgonia verrucosa in the Mediterranean; Schröter on the G. Flabellum, which grows in the Indian seas, and Bruguiere, enveloped in the horny substance of different corallines of the same genus, from the Asiatic ocean. 


\section{PARROT-BEAKED ACORN.}

17. Lepas Psittacus. L. testa posterius adunca sexvalvi rugosa. Linn.

Gmel. p. 3212. Molin. Hist. Nat. Chil.p. 179.

Shell of six valves, hooked behind, and wrinkled.

This is an obscure species, mentioned by Molini, and found in clusters on the coast of Chili. It adheres to rocks. The two larger valves resemble a parrot's bill: the flesh is white, tender, and palatable. From the account which Molini gives of this shell, it appears to be a variety of the $\boldsymbol{L}$. Tintinnabulum rather than a distinct species.

\section{SPINY ACORN.}

\section{Pl. 7. f. 4, 5. Mr. SoWERBY.}

18. Lepas spinosa. L. testa conica, areis duodecim triangularibus: sex depressioribus minoribus albidis transversim striatis, sex purpureis longitudinaliter striatis, spinisque tubulosis recurvis armatis. Linn. Gmel. p. 3213.

Shell conic, with twelve triangular compartments: the six smaller ones depressed whitish and transversely striated, the other six purple, striated longitudinally, and armed with tubular recurved spines.

Balanus, testa subcylindrica, valvulis incequalibus quadrifariam spinosis, radiis transversè striatis. Brug. Encyclop. Method. Hist. Nat. tom. 6. p. 167.

Davila Catal. tom. 1. p. 402. t. 6. f. N. Favanne Conch. t. 59. f. A. 1. Schröt. n. Litterat. 1. p. 430. t. 2. f. 10. Chem. Conch. 8. t. 98. f. 840. \& t. 99. f. 841. Encyclop. Method. pl. 164. f. 9, 10.

This shell is generally of a reddish or purple colour on the outside, and white within; though it varies in this respect, being sometimes of a pale grey, and even whitish all over. The internal substance of the valves is very porous: the operculum consists of four thin triangular valves, striated transversely.

VOL. I. 
The large specimen, fig. 4 , is an old shell of the same species, which has lost its spines, except the rudiments of one or two that still remain on its upper surface. The two young shells fixed on its side were probably from eggs ejected by the parent.

\section{FLESH-COLOURED ACORN.}

Pl. 7. f. 6. Mrs. MaWE.

19. Lepas minor. L. testa rubicunda sexvalvi inaquivalvi, operculo acuminato. Linn. Gmel. p. 3212.

Shell of six unequal valves, reddish; operculum sharp-pointed.

Balonus, testa conica, transversè striata albo punctata, radiis lavibus, operculo postice bicorni. Brug. Encycl. Meth. Hist. Nat. tom. 6. p. 168.

Lepas tulipa minor, apertura angustiore quam basi. Chem. Conch. 8. t. 97. f. 827. Encyclop. Method. pl. 164. f. 14.

A conic shell, with a pointed beak and six smooth unequal valves, the two nearest the beak being much smaller than the rest. Valves marked longitudinally with faint reddish lines, and concentrically with white. The union of the lines gives the upper part of the shell, when magnified, a whitish dotted appearance. Some shells are quite white.

This species inhabits the Indian seas, and is generally of a flesh colour inclining to violet.

RAYED ACORN.

Pl. 7. f. 7. Mr. SoWERBY.

20. Lepas radiata. L. testa sexvalvi lavi, exterius violacea longitudinaliter radiata.

Shell of six valves, smooth, marked with longitudinal violet rays.

This is a small thick shell, about five-eighths of an 
inch broad at the base, and a quarter of an inch high. The valves are triangular and painted with violet rays, which are close together at the apex, but more open at the circumference: the intermediate compartments are highly polished, and very finely striated transversely.

Many of these shells were found fixed to the bottom of a ship. Their country is unknown.

\section{PALMATED ACORN.}

21. Lepas palmipes. L. testa erecta conica, valvulis basis palmatis. Linn. Gmel. p. 3209. Mant. pl. 2. p. 544.

Shell erect and conic; valves palmate at the base.

A white shell, the size of a large pea, smooth, and somewhat depressed: the valves are divided from the base as far as the middle, into five or six fingered segments : the operculum is obtuse and four valved. The digitated divisions of the valves are irregular, and not unlike the fangs of the molar teeth.

Inhabits the ocean, but what part is not mentioned.

\section{RUGGED ACORN.}

Pl. 8.f. 1, 2, 3, 4. Mr. SOWERBY.

22. Lepas crispata. L. testa ovali truncata conica, areis sex carulescentibus albo obumbratis, sex aliis elevatis rubellis spinosis perpendiculariter striatis. Linn. Gmel. p. 3214.

Shell oval truncated and conic, with six bluish valves shaded with white, and six reddish valves spinous and striated perpendicularly.

Balanus crispatus. B. testa conica truncata, valvulis apice nudis, inferne muricato crispatis. Brug. Encyclop. Method. Hist. Nat. tom. 6. p. 166.

Schröter Einl. in Conch. 3. t.9. f. 21. Favanne Conch.t. 59. f. A. 9. Encyclop. Method. pl. 164. f. 11.

This shell, for the knowledge of which we are in- 
debted to a learned German conchologist, M. Schröter, is about an inch high, and an inch and a half broad at the base. It has six raised and six depressed compartments; the former are very rugged, and resemble the rough bark of a tree; they are violet at top and greenish towards the base: the latter are of a more uniform violet colour, shining, and striated transversely. The opening is nearly triangular; and the operculum, according to Schröter, is composed of four valves, the two anterior of which are striated obliquely. The base of the shell is singular; it is formed of a series of striated laminæ with serrated edges. These laminæ are irregular; the outer edge is flexuous, and the general appearance of the base is not unlike a Madrepore.

This shell was found by Mr. Sowerby, fixed to the bottom of a vessel in the Thames. It has several small specimens of the $\boldsymbol{L}$. porcata on its sides, which were purposely omitted in the plate. Fig. 3. and 4. represent the same shell in a young state, in which, without particular attention, it may be mistaken for a distinct species. Favanne has figured a young shell. The French have copied Schröter.

\section{RIDGED ACORN.}

Pl. 8. f. 5. Mr. Sow ERBY.

23. Lepas porcata. L. testa conica, longitudinaliter porcata, violacea, apertura subovata.

Shell conic, ridged longitudinally, of a violet colour, with a somewhat oval mouth.

This shell has six unequal valves, strongly ridged longitudinally. The colour is violet, much deeper in the furrows than on the ridges. Ridges, in the spe- 
cimen figured, very irregular. Depressed compartments narrow and smooth. Base testaceous.

It does not appear that this shell has been hitherto described, though it is not a very rare species. The Lepas from the East Indjes with violet rays, which Chemnitz has represented, vol. 8. pl. 99. fig. 842. bears a strong resemblance to the $L$. porcata, but is not the same shell.

Specimens of a regular bell shape and more uniformly ridged, occur in the Museum of the Linnæan Society.

\section{VIOLET ACORN.}

24. Lepas violacea. L. testa crassa, glabra, sexvalvi alba, radiis violaceis. Linn. Gmel. p. 3213.

Shell thick, smooth, of six valves, white with violet rays.

Balanus radiatus. B. testa conica longitudinaliter sulcata, lineis violaceis picta, radiis lavibus. Brug. Encyclop. Method. Hist. Nat. t. 6. p. 168.

Lepas India Orientalis ex violacea radiata. Chem. Conch. tom. 8. pl. 99. f. 842. Encyclop. Method. pl. 164. fig. 15.

This is described by Chemnitz as a conical shell with a large oval base. It has six unequal valves grooved longitudinally and rayed with violet in the same direction. The intermediate compartments are smooth and without striæ: the opening is oval, a little compressed behind: the operculum is quadrivalve and striated transversely: the two posterior valves of the operculum are pointed. The shell is of a clear violet colour with lines of a deeper tint. It inhabits the Indian ocean.

Bruguiere considers this as a very rare species, not to be found in any collection in Paris. 


\section{LIMPET ACORN.}

25. Lepas patellaris. L. testa sexvalvi, exterius violaceo albo mista, subtiliter longitudinaliter striata, intus falcata, valvis margine denticulatis. Linn. Gmel. p. 3213.

Shell of six valves; the outside violet mixed with white and finely striated lengthways; inside hooked; valves toothed at the margin.

Balanus patelliformis. B. testa depressa, costis quinis radiatis angulata, apertura subpentagona. Brug. Encycl. Meth. Hist. Nat. tom. 6. p. 169.

Spengl. Schr. Naturf. tom. 1. pl. 5. f. 4. Chem. Conch. 8. pl. 98. f. 839. Encyclop. Method. pl. 165. f. 3.

This species so strongly resembles the Astrolepas of Argenville, Patella saccharina Linn., that it would be difficult to distinguish it, but for its central aperture.

It is a compressed cone with six valves, articulated as in the other species, and five prominent angles, forming as it were a pentagonal star. The mouth of the shell is only the tenth part of an inch wide, though the base measures nearly an inch in its greatest diameter. The operculum has not been noticed. The shell is of a brown colour variegated with whitish streaks.

The specimen which Spengler obtained, and figured, was strongly attached to the branch of a tree from the coast of Coromandel.

\section{HEMISPHERICAL ACORN.}

26. Lepas hemispherica. L. testa convexa, valvulis sex requalibus, trilobis, operculo convexo quadripartito.

Shell convex with six equal three-lobed valves: operculum convex and four-parted.

Balanus hemisphericus. Brug. Encycl. Meth. Hist. Nat. tom. 6. p. 170. Ibid. Art. Vers. pl. 165. f. 4, 5, 6.

This is a small species described by Bruguiere from 
some specimens attached to a muscle shell, and brought from the coast of Africa by Poiret. The largest are three lines in diameter at the base, and a line and a half high. The shell has six valves, each divided into three channels, the deepest in the middle. The valves are separated by six rays, as straight as a thread. The aperture is oval; the operculum convex and quadrivalve: when magnified the valves appear striated. The colour of the shell is white.

Bruguiere refers to Chemnitz, vol. 8. t. 98. f. 833, for his shell, but it bears so slight a resemblance to the figure in the Encyclop. Melhod. that we are not disposed to consider it as the same.

\section{PURPLE-TIPPED ACORN.}

Pl. 9. f. 1, 2, 3. Mrs. Mawe.

27. Lepas purpurascens. L. testa subconica, purpurca, rugosa, cellulosa ; valvulis quatuor: apertura subangulota coarctata.

Shell subconic, purple, rough and cellular: valves four; aperture narrow and rather angular.

The valves of this shell are so firmly united to each other, that the line of separation is seldom apparent, and the cone in consequence seems uniform. This is the case with fig. 3 . in which state the shell is usually found, and it must be remarked that it appears flat in the plate, owing to the position of the eye, which is looking down upon the figure in order to see the size and shape of the aperture. Figure 1. is an instance more rarely met with, where the valves are separated and show the four depressed compartments. The connecting sutures appear so strong, that it must require great force to disunite them. The shell is tipped with 
dark purple with a light wash of the same towards the base, which is greenish. The walls are very thick and perfectly cellular, as represented in fig. 2 . It is a rugged shell at at all times, but more particularly so when the valves are separated. Inhabits the South seas.

\section{POROUS ACORN.}

\section{$P l$. 9. $f$. 4. Dr. Соомв .}

28. Lepas porosa. L. testa granulato striata, conica, tubulosa ; operculo obtuso. Linn. Gmel. p. 3212.

Shell with granulate strix, conic, tubular : the lid obtuse.

Balanus squamosus. B. testa conica, cellulosa, extus squamis oblongis adpressis vestita, apertura subrotunda coarctata. Brug. Encycl. Meth. Hist. Nat. tom. 6. p. 170.

Ellis, Phil. Trans. vol. 50. p. 852. pl. 34. f. 11. Schröter, Journ. 4. pl. 2. f. 6. Favanne, Conch. pl. 59. f. A. \%. Chem. Conch. 8. pl. 98. f. 836, 837. Encyclop. Method. pl. 165. f. 9, 10.

This species forms a regular cone, with the base nearly twice the diameter of its height. The surface is covered with linear excrescences, which are tubular and terminate in openings at the base of the shell. Like the preceding species it has four valves, which are so closely connected together that no vestige of union appears, except on the inside. The aperture is roundish, and larger in proportion than in the preceding species. The valves are thick and full of cells. The colour is whitish or cinereous, and the size from that of the figure to more than twice the diameter. 
WART-SHAPED ACORN.

Pl. 9. $f$. 5. Mr. Gibis.

29. Lepas Verruca. L. testa quadrivalvi, depressiuscula, operculis indistinctis plicatis, valvulis interteittis striatis.

Shell of four valves, somewhat depressed, operculum obscure and pleated; valves interlaced and striated.

Lepas Verruca. Linn. Gmel. p. 3212.

Balanus, testa depressa oblique lamelloso-striata, apertura subquadrata, operculo bivalvi. Brug. Encycl. Meth. Hist. Nat. tom. 6. p. 169.

Spengl. Schr. Berl. Naturf. 1. pl. 5. f. 1, 2, 3, 5. Da Costa, Brit. Conch. p. 250. Penn. Brit.Zool. ed. 1812. 4. pl.41. Chem. Conch. 8. pl. 98. f. 834. Encyclop. Method. pl. 164. f. 16, 17. Donov. Brit. Shells, pl. 36. f. 1. Mont. Test. Brit. p. 12. Linn. Trans. 8. p. 26.

A compressed subconical shell, greatly resembling a wart, and very unlike every other species of the genus. The valves are strongly ribbed and interlace with each other; aperture oblique and closed by an operculum, which, according to Bruguiere, is of two valves, but so obscure as not to be distinguished except in live shells. It is a very small species, being seldom more than a quarter of an inch in diameter; was first noticed as British, by Pennant; and is found on shells, stones, and other substances. It has also been brought from Iceland, and from Cape Horn.

Bruguiere describes this shell as having three valves only, but Mr. George Sowerby has examined the species with great attention, and discovered a fourth valve which escaped the notice of the French Naturalist. These valves are represented in pl. 9, surrounding the principal figure, 
NORWEGIAN ACORN.

30. Lepas Stroemia. L. conico-convexa, valvis quatuor serrato-striatis; operculo bivalvi. Linn. Gmel. p. 3214. Muller.Zool. Dan. 3. p. 21. t. 94. f. 1.4. Prodr. No. 3025.

Shell conico-convex, with four saw-striated valves: operculum of two valves.

This species, which is named by Muller after the Rev. Mr. Stroem, inhabits the Norwegian seas.

\section{CARIOUS ACORN.}

31. Lepas cariosa. L. testa solida, alba, depressa, sulcato cariosa, intus inaquali lavi. Linn. Gmel. p. 3214.

Shell solid, white, depressed, with carious grooves; within smooth and unequal.

Pall. Nov. Act. Petrop. 2. p. 240. t. 6. f. 24. A. B.

A rude shell with the appearance of being much worn and perforated in several parts. About two inches and a quarter in diameter. Inhabits the Kurile Islands. Mentioned only by Pallas.

There is a very small species of Lepas described and figured in the new edition of the British Zoology, under the name of Lepas convexula. It is found on rocks and limpets on the coast of Anglesey, and is little more than the twentieth of an inch in diameter. Is it not the spawn of a larger shell? 


\section{*㫧㐘 With Compressed Shells.}

MITRE BARNACLE.

$P l$. 10. $f$. 1. Mrs. Maw E.

32. Lepas Mitella. L. testa compresso-erecta difformiter striata. Linn. Syst. Nat. ed. p. 1108. Linn. Gmel. p. 3210.

Shell compressed, erect, and irregularly striated.

Anatifa Mitella. A. testa compressa, valvulis inaqualibus numerosis striatis intestino squamoso. Brug. Encycl. Method. tom. 6. p. 65.

Rumph. Mus. pl. 47. f. M. Petiver Gazoph.pl.6. f. 10. Ellis, Phil. Trans. vol. 50. pl. 23. f. 4. Seba. Mus. 2. pl. 61. f. 8. and 3. pl. 16. f. 3. Favanne, pl. 59. f. B. 2. Chem. Conch. 8. t. 100. f. 849, 850. Encyclop. Method. pl. 166. f. 9.

The Lepas Mitella has eight principal valves besides a wreath of small ones round the base of the shell: the central valves are in pairs, corresponding exactly with each other, but the end valves are single and decidedly carinated. The shell is strongly striated, or rather ridged, and where the yellow coat is removed, appears of a polished white. It must be remarked that the striæ in general are curved, but more particularly so in the two most prominent valves. The inside is smooth and of an ivory white. The pedicle, or stalk, when it occurs, is about an inch long, of a grey brown colour, and covered with scales like that of the following species but of a larger size.

This shell inhabits the Indian seas, particularly near the Island of Amboyna. It is rare to find a good specimen in the cabinets of Natural History, and still more rare to find it perfect with its pedicle.

The best figure of this species is by Petiver. 


\section{CORNUCOPIA BARNACLE.}

Pl. 10. f. 2. Mrs. Mawe.

33. Lepas Pollicipes. L. testa compresso-erecta, multivalvi lavi; pedunculo coriaceo, brevi, duro, squamoso insidente. Linn. Gmel. p. 3213. Shell compressed, erect, many valved, smooth; seated on a short, hard, scaly, coriaceous foot-stalk.

Anatifa Pollicipes. A. testa compressa, valvis quindecim et ultra levibus difformibus, intestino granulato squamoso. Brug. Encycl. Meth. Hist. Nat. tom. 6. p. 65.

Lister, Syn. Conch. t. 439. f. 281. Ellis, Phil. Trans. vol. 50. p. 850. pl. 34. f. 4. Knor. Vergn. tom. 5. pl. 13. f. 7. D'Argenville, Conch. pl. 30. f. E. ejusd. Zoom. pl. 7. f. 6. Favanne, Conch. pl. 57. f. B. 1. item pl. 74. f. G. 1. Chemn. Conch. 8. pl. 100. f. 851, 852. Encyclop. Method. pl. 166. f. 10, 11. Mont. Test. Brit. Suppl. p. 6. pl. 28. f.5.

This shell, like the preceding species, has eight principal valves, besides many of a smaller size. Those at the base are placed in a very irregular manner, and some of them are as small as seed pearls. The four large valves, which are smooth and of the colour and appearance of horn, turn towards each other like the beak of a bird. The shell in all its parts is thick and solid; the valves are more or less convex, and connected together by a blackish membrane.

The pedicle, or foot stalk, is thick and short, rarely exceeding an inch and a half in length. It is of a bluish ash-colour and studded with little points, or scales, which give it the appearance of shagrin.

Groups of these shells, sometimes of more than twenty in a cluster, are found in the Mediterranean, and on the coast of Spain. They are also so abundant on the shores of Brittany, and Normandy, that they are sold as an article of food in the neighbouring towns and villages, where they are boiled in water and eaten with 
vinegar. Rondeletius says that they are particularly grateful to women, and delicate persons whose excesses have injured their appetite. Mulieres et delicatiores homines alia fastidientes cibaria hoc eduli genere delectantur, et qui veneri dediti sunt

It is this species which the French call pouce-pied from the resemblance it bears to the toe nail.

\section{PEN-KNIFE BARNACLE.}

Pl. 10. f. 3. Mr. Sowerb $Y$.

34. Lepas Scalpellum. L. testa compressa tredecimvalvi laviuscula, pedunculo squamoso insidente. Linn. Syst. Nat. ed. 12. p. 1109. Linn. Gmel. p. 3210.

Shell compressed, of thirteen valves, smoothish and seated on a scaly peduncle.

Anatifa Scalpellum. Brug. Encycl. Meth. Hist. Nat. tom. 6. p. 64. Ellis, Phil. Trans. vol. 50. t. 34. f. 2. item 2. a. Gualt. Test. pl. 106. f. C. D'Argenville, Conch. t. 26. f. G. Favanne Conch. t. 59. C. 6. Muller, Vollst. Natur. Syst. t. 6. pl. 10. f. 7. Chemn. Conch. 8. p. 338. vignette 17. at p. 294. f. a. A. Encyclop. Method. pl. 166. f. 7, 8. Donov. Brit. Shells, pl. 166. Pultn. in Hutch. Dorset. t. 2. f. 8. Mont. Test. Brit. p. 18. pl. 1. f. 3. Linn. Trans. 8. p. 27. Penn. Brit. Zool. ed. 1812. pl. 4. p. 151.

This species is composed of thirteen unequal and irregular valves, six of which are placed on each side, and the thirteenth forms the back. The three lower valves are smaller than the rest, and the posterior one projects a little at bottom into a knob, or beak. The dorsal valve curves towards the upper part of the shell, and terminates in a point. This curvature gives it the pen-knife figure, and probably suggested to Linnæus the trivial name. The valves are connected together by a transparent red membrane, which lines their internal surface, and appears to be a prolongation of the pedi- 
cle. The pedicle is very short, of a cylindrical shape, and covered with short hairs.

The $\boldsymbol{L}$. Scalpellum inhabits the North seas; Linnæus observed it on the coast of Sweden, Muller on that of Denmark, and it also occurs, though rarely, in the British ocean. It is never found thrown on the shore like other shells, but is taken in the deep, and always attached to some other body. The specimen figured in pl. 10 adheres to the lobster horn coralline, Sertularia antennina. It is not uncommonly attached to different species of the genus Gorgonia, and sometimes to Fuci. The valves are often encased in extraneous matter, so that the divisions are not visible. In this state it is represented by D'Argenville, and also by Ellis at fig. 3.

Gmelin's reference to Lister and Klein for this shell is wrong. Lister has figured the $\boldsymbol{L}$. Pollicipes, and Klein, of course, has copied him.

\section{BLADDER BARNACLE.}

Pl. 10. f. 4.

35. Lepas fascicularis. L. testa quinquevalvi lavi, valvula dorsali basi dilatata angulo acuto prominente. Linn. Trans. 8. p. 30.

Shell of five valves, smooth; dorsal valves spread at the base and having an acute prominent angle.

Seb. Mus. vol. 3. t. 16. No. 1. 6. Ellis Zooph. p. 167. pl. 15. f. 6. Encyclop. Method. pl. 166. f. 4. Donovan Brit. Shells, pl. 144. Mont. Test. Brit. p. 557. item Suppl. p. 5. and p. 163.

The principal valves of this shell are concentrically wrinkled from the exterior angle to the base, and faintly radiated with striæ from the same point across the wrinkles. The dorsal, or ridge valve, is singularly dilated at the base, and has a sharp prominent angle, or 
heel, which terminates the carinated edge of the upper part of the valve. The two superior valves end in a point above the dorsal valve. The shell is very thin and light, of a horn colour, and in appearance resembling pieces of dried bladder more than any other substance.

Mr. Montagu, to whom we are indebted for the best information relative to this species, says that the colour of the shell, while containing the animal, is bluish; that these shells were once thrown up in abundance on the south coast of Devon, between Milton and Shurlstone; and that they were attached in groups, some to a yellow variety of the Fucus vesiculosus, others to a slenderleaved Conferva; one group to the quill feather of a gull, and another to a bit of charcoal. Each was fixed to its respective substance by a short pedicle, which shrinks so much in drying, that the shell, as figured in pl. 10, appears seated on the Fucus without any intermediate support.

This must be considered as a rare species; for if we except a solitary specimen found by the late Mr. Bryer, and its accidental occurrence on the coast of Devon, it has not been observed for a period of more than forty years. The opportunity of collecting them in Devonshire seems to have been of very short duration, since Mr. Montagu remarks, that in two or three days after their appearance, there was scarcely a vestige of them left.

The specimen figured in $\mathrm{pl}$. 10. was covered with a greenish film. 
STRIATED BARNACLE.

Pl. 10. f. 5. Mr. Sowerby.

36. Lepas anserifera. L. testa compressa quinquevalvi striata, pedunculo insidente. Linn. Syst. Nat. ed. 12. p.1109. Linn. Gmel.p. 3210. Shell of five valves, compressed and striated; seated on a peduncle. Anatifa striata. Brug. Encycl. Meth. Hist, Nat. tom. 6. p. 64. Lister, Conch. t. 440. f. 283. item. Exerc. Anatom. t. 19. f. 4, 5. Chemn. Conch. 8. pl. 100. f. 856. Encyclop. Method. pl. 166. f. 3. Donov. Brit. Shells, pl. 166. Mont. Test. Brit. p. 16. Penn. Brit. Zool. ed. 1812. vol. 4. p. 151. Linn. Trans. 8. p. 28.

The surface of this shell is strongly striated, the strix extending, in the lower valve, from the anterior angle to the edge, where it unites with the upper valve: these striæ are crossed again so as to give the shell a reticulated appearance. The upper valve is striated in the same manner as the lower one, but somewhat stronger. The dorsal valve is much compressed and has a carinated edge. The shell is of a bluish colour, with an orange red pedicle, an inch and a half long.

Inhabits the American ocean. Has been found on the coast of Devonshire, by Mr. Montagu, on a piece of drifted wood, from half an inch in length to the size of the figure.

Gualtieri has figured a single valve only, the reference to him has therefore been omitted. 
DUCK BARNACLE.

Pl. 11. Mr. SowerbY.

37. Lepas anatifera. L. testa subtriangylari, quinquevalvi, lavi, pedunculo longo insidente. Linn. Syst. Nat. ed. 12. p. 1109. Linn. Gmel. p. 3211.

Shell subtriangular, of five smooth valves, seated on a long foot stalk.

Anatifa lavis. Brug. Encycl. Meth. Hist. Nat. tom. 6. p. 62.

Gualt. Test. t. 26. f. E. Seba Mus. 3. t. 16. f. 1, 2. Knorr. Vergn. 2.

1. 30. f. 4, 5. Ellis, Phil. Trans. vol. 50. t. 34. f. 5. 6. Muller, Vollst. Natur. Syst. tom. 6. pl. 10. f. 8. Da Costa, Brit. Conch. pl. 17. f. 3. Penn. Brit. Zool. ed. 1812. vol. 4. pl. 41. Chemn. Conch. 8. pl. 853-855. Encyclop. Method. pl. 166. f. 1. Donovan, Brit. Shells, pl. 7. Mont. Test. Brit. p. 15. Linn. Trans. 8. p. 28.

A bluish white shell with five valves, four of which are faintly striated; the fifth, or dorsal valve, is smooth down the middle, and sulcated at the sides. It differs principally from the preceding species, or $\boldsymbol{L}$. anserifera, in the large valves, which are not sharply carinated, as in that shell; in the superior valves, which are truncated at the apex; and in the strix, which are much fainter in the $\boldsymbol{L}$ : anatifera. These shells are found in considerable clusters, from half an inch to an inch and three quarters in length, and more than an inch in extreme breadth. They are seated on a flexible pedicle, which is sometimes a foot long. The specimen figured in pl. 11. was, among many others, alive in a tub of sea water, and had a cluster of young ones branching from its side. The drawing was made while the animals were extending their plumose tentacula in search of food, and while the orange colour of the membrane which lines the valves, and which is often lost in drying, was in all its beauty. The pedicle was 
not, as it is generally described, of a saffron colour, but brown as in the figure. It was much too long to be introduced into an octavo plate, we have therefore represented only a portion attached to a piece of wood, its usual support. This pedicle resembles a small intestine; it is tendinous, cylindrical, and capable of great contraction; while the animal is alive it is filled with a glairy mucilage, which exsudes after death, and leaves the foot stalk empty and withered.

This shell is very abundant in many parts of the world. Linnæus noticed it in the North; Muller on the coast of Denmark; Pennant and others in the British seas; Plancus in the Mediterranean; and Seba and Davila in the Asiatic ocean. It adheres to the bottoms of ships, and to floating pieces of wood.

An idle story was formerly told about the capability of this shell to produce the Barnacle Goose, and, like other idle stories, was readily believed. Old Gerard, with inflexible credulity, declares that the shell contains a young bird, which " when it is perfectly formed, the shell gapeth open, and the first thing that appeareth is the lace, or string (the plumose tentacula); next come the legs of the bird hanging out, and as it groweth greater it openeth the shell by degrees, till at length it is all come forth, and hangeth onely by the bill : in short space after it commeth to full maturitie, and falleth into the sea, where it gathereth feathers, and groweth to a fowle bigger than a mallard and lesser than a goose," \&c. Gerard prefaces his account with "what our eyes have seene, and hands have touched, we shall declare;" and, that the strength of evidence may not be wanting, concludes by an invitation to all 
those who may doubt the truth of his assertion, to repair unto him, and he will satisfy them by the testimony of good witnesses.

Such was the absurd notion which formerly prevailed, but which may now be ranked with the seducing song of the siren, the prophetic chant of the swan, and the irresistible force of the remora.

\section{DOWNY BARNACLE.}

38. Lepas villosa. L. testa compressa, quinquevalvi lavi; pedunculo villoso.

Shell compressed of five smooth valves; pedicle downy.

Anatifa villosa. Brug. Encycl. Meth. Hist. Nat. tom. 6. p. 62.

This shell is described by Bruguiere as a distinct species, greatly resembling the $\boldsymbol{L}$. anatifera in the valves, but differing specifically in the pedicle. It is a small shell, never exceeding five eighths of an inch in length : the valves are smooth, but the foot-stalk is covered with short flexible hairs, which, while the animal is alive, resemble mould, but which fall off with the slightest touch when the shell is dried. This species was observed by Bruguiere on the poop of a ship, in the port of Cette, in Languedoc. He remarks that it is solitary, never appearing in clusters like the other barnacles.

\section{TOOTHED BARNACLE.}

39. Lepas dentata. L. testa compressa, quinquevalvi, lavi, valvula dorsali carinata, dentata, pedunculo rugoso.

Shell compressed, of five valves, smooth, dorsal valve keel-shaped and toothed, pedicle wrinkled.

Anatifa dentata. Brug. Encycl. Meth. Hist. Nat. tom. 6. p. 63.

Concha anatifera margine muricata. Lister, Conch. t. 439. f. 282. Klein, Ostrac. t. 12. num. 91, 92.

This shell has hitherto been confounded with the 
$\boldsymbol{L}$. anatifera, but is now separated by Bruguiere, upon a very sufficient foundation. It resembles the duck barnacle in every respect, except the dorsal valve, which is strongly carinated, and divided throughout its length into many very sharp teeth. Lister is the only author who has described this species (not to mention Klein, whose figure is copied from Lister,) except Bruguiere, and the specimen which he observed was more decidedly toothed, and the teeth were deeper and more numerous than in the shell represented by Lister. It inhabits the Mediterranean, and is found in groups like the common species, but is smaller.

\section{FURROWED BARNACLE.}

Pl. 12. $f$. 1. Mr. SoWERBY.

40. Lepas sulcata. L. testa subtriangulari, quinquevalvi, sulcata. Linn.

Trans. 8. p. 29.

Shell somewhat triangular, five valved, sulcated.

Mont. Test. Brit. p. 17. pl. 1. f. 6.

We are indebted to Mr. Montagu for this new and elegant species of barnacle, which he found adhering to the Gorgonia Flabellum on the Dorsetshire coast, near Portland Island. The lower valves have from fifteen to nineteen ribs diverging from the lower angle to the margin, where they are met by seven or eight corresponding ribs in the superior valves. It must be noticed that the anterior rib of the lower valve is always the strongest. The dorsal valve is somewhat keeled, and marked with strong longitudinal striæ. Pedicle extremely short, and seldom to be seen. Colour of the shell faint bistre, often sordid white. Length from one tenth to half an inch. Breadth of the largest, four tenths of an inch. 
The author has several of these shells seated on pieces of cuttle-bone, with clusters of small ones round the bottom of each. A group of them, some of a large size, attached to a piece of rotten wood, is in the possession of Mr. Sowerby, and is the specimen represented in the plate.

\section{RIBBON BARNACLE.}

Pl. 12. $f$. 2, 3.

41. Lepas vittata. L. carnosa, continua, glauca, vittis nigris, superne truncata acuminata, testis quinque angustis marginalibus. Solander, MS. in Biblioth. Banks.

Animal fleshy, uniformly green with black stripes, truncated at top, and sharp pointed; shells five, narrow and marginated.

Seba, Mus. 3. t. 16. f. 5. Poli, Test. t. 6. No. $20 \& 22$.

The testaceous part of this singular species consists of five narrow valves, the two largest of which are placed on the margin of the aperture, and are triangular; the dorsal valve is linear and subcarinated; the two superior valves are also linear, reflex, and terminate in points at the anterior extremity. The membranous bag which encloses the animal, is of a greenish colour, with six black longitudinal stripes, three on each side. The pedicle is a continuation of the same, and the whole is about two inches long, and five-eighths of an inch broad.

Inhabits the Mediterranean and Atlantic ocean. Dr. Solander observed it on the sides of the Endeavour, as he sailed between the Canary Islands and Brasil, and Bosc found it on the ship which carried him from America to Europe. 
42. Lepas membranacea. L. carnosa, alba, superne truncata, acuminata, testis quinque angustis marginalibus.

Animal fleshy, white, truncated at top and acuminate; shells five, narrow and marginated.

Mont. Test. Brit. Suppl.p. 164.

This species differs from the preceding in the membrane only, which is quite white, and without any stripes. It is less than the other, the largest specimen in the possession of the author not exceeding an inch and a quarter in length. The principal valves in both somewhat resemble the hammer oyster in shape. Mr. Montagu, to whom we are indebted for the knowledge of this shell, has reason to believe that it was taken on the Welch coast.

The valves, both of this and the preceding species, are the rudiments of shells; the beginning of operations which are completed in the $\boldsymbol{L}$. anatifera.

\section{EARED BARNACLE.}

Pl. 12. $f$. 4. Dr. LEACH.

43. Lepas aurita. L. testa membranacea, ventricosa, tubo insidente, ore octovalvi dentato; tubulo gemino aurito. Linn. Syst. Nat. ed. 12. p. 1110.

Shell membranaceous, ventricose, seated on a tube and eared: mouth of eight valves, toothed.

Lepas nuda carnosa aurita. Ellis, Phil. Trans. vol. 50. pl. 34. f. 1.

Seba, Mus. 3. t. 16. f. 5. Edw. av. 2. t. 286. f. A. Chem. Conch. 8. pl. 100. f. 857, 858. Brug. Encycl. Meth. Hist. Nat. tom. 6. p. 66.

This species has a membranous, cylindrical stalk, dilated at top, and terminating in two tubular appendages, or ears. The aperture through which the animal 
protrudes its tentacula, is oval, and has two testaceous cruciform valves situated at the inferior extremity. The feelers (or tentacula) are singular, the lower portion of each terminating in a tendril. The body is of a greenish colour. Inhabits the North seas, and has been found by Muller on the coast of Norway.

Two groups of eared barnacles, attached to the $\boldsymbol{L}$. Diadema, are preserved in Hunter's Museum; from one of these Ellis copied his figure. 



\section{Genus 3.}

\section{PHOLAS.}

\section{GENERIC CHARACTER.}

Animal Ascidia.

Testa bivalvis, divaricata, cum minoribus accessoriis difformibus, ad cardinem.

Cardo recurvatus, cartilagine connexus.

Animal an Ascidia.

Shell, two-valved, divaricated, with smaller accessory valves of a different shape at the hinge.

Hinge folded back, connected by cartilage.

\section{GENERAL OBSERVATIONS.}

The species of this genus vary in the number of their accessory valves, which are in all very fragile, and so slightly connected to the shell, that we rarely find them quite perfect. The two principal valves are, for the most part, open at both ends, and their surface, which is generally striated, is in some species as rough as a file. The animal inhabiting this genus of shells has a very thick membranous mantle, or sheath, open at both ends. From the superior opening of this mantle proceeds a double neck, or two united siphons, one of which is larger than the other. These siphons are slightly toothed on their edges, and serve, one for the entrance, and the other for the exit of the food. The animal has likewise a foot which is short and conic.

The faculty which these soft animals possess of penetrating hard substances, such as stones and wood, has 
long excited the attention of philosophers, though they have hitherto been unable to divine the cause. The opinion of Reaumur, that they work their way into limestone and other hard bodies, by the continual rotation of their valves acting like a rasp, is not satisfactory, since there are some species, and particularly the $\boldsymbol{P}$. Orientalis, which are nearly smooth at the anterior end, and consequently unfit for such a purpose. That they do not bury themselves while the substance which they choose for their habitation is in a soft state, may be inferred from their penetrating wood, and from the lodgement which they have made in the pillars of the temple of Serapis at Puteoli. Dr. Bohadsch, who noticed these pillars, concludes that the Pholades must have bored their holes within them after they were erected; for he observes that the workmen would certainly have rejected any stones from their building, that had been perforated in so many places by these creatures. The Pholades must therefore have worked their way into them while they were buried by the influx of the sea, which immediately succeeded the destruction of the city by an earthquake.

It must be remarked that the animal is enabled to enlarge its habitation on the inside, since the cavity is always smaller at its entrance than the pholas itself. This fact proves also that, when once settled, there is no receding, and that the dark chamber which it has chosen, must serve the animal for a sepulchre, unless it be previously dragged from its hole to be used as an article of food, or as a bait for other fish.

On the coasts of Normandy they are eaten in abundance, well seasoned and cooked with bread crumbs and fine herbs. They also pickle them in vinegar, and 
reckon them a delicacy. In the neighbourhood of Dieppe, a great many women and children, each provided with an iron pick, are employed to collect the Pholades, either to sell in the market, or to be used as bait by the fishermen.

The pholas is remarkable for its phosphorescent property. This is noticed by Pliny, lib. 9. c. 61. Aristotle and Athenæus have mentioned the pholas, but in too slight a manner to be worthy of observation.

Before we quit the general remarks on multivalve shells, it will be proper to observe, that an Italian naturalist, M. Giœni, has described and figured what he conceived to be a new genus in the class of multivalves, under the title of Descrizione di una nuova Famiglia e di un nuovo Genere di Testacei. Neapoli 1783. It would have been well if the author of the above tract had confined himself to the description only of the shell; but he has indulged in a tale of the habits and manners of the animal part of his subject, which is quite ridiculous. The subject of M. Giœni's paper is the gizzard of the Bulla lignaria, which is testaceous, and when separated from the body of the animal, may readily be mistaken for a shell. So far the description of $\mathbf{M}$. Giœni, who probably found the substance on the sea shore, is excusable; but when he gravely relates as a fact, what he at the same time knows to be false, it becomes the duty of the naturalist to expose his error, that subsequent writers may not be misled. After describing the three valves with which this supposed shell is provided, M. Giœni proceeds to tell us that the animal has a long trachea, or trunk, through which it respires and receives its food; that it is born and lives under the sand; and that when it wishes to rise 
to the surface, it opens a passage for itself by means of its testaceous shield, which it moves on all sides, and by which alone it mounts to the surface of the sand, \&c.

M. Giœni then describes the manner in which the animal moves, by pressing the end of his shield against the sand, and thus obtaining a point of support, while he slowly drags the rest of the body after him. But this operation is so painful, and is executed so heavily, that the animal leaves a trace behind it, from the impression of the great valves, in the sand, which resembles in miniature the track of carriage wheels!! The calculation of the time which the animal takes to move along the sand, is admirable. M. Giœni reckons it at the twelfth part of an inch in eight seconds! Much more of a similar detail equally absurd is entered into by the Italian naturalist; but enough has been said to prove the falsity of the rest. The circumstantial manner in which the whole has been related, however, and the accurate figures, (for they are accurate as far as relates to the gizzard of the $\boldsymbol{B}$. lignaria, ) with which the account is illustrated, has misled Retzius, who, in a tract entitled Nova Testaceorum Genera, published in 1788, has described the trivalved gizzard, under the name of Tricla Gioni; and Bruguiere has formed a new genus of it, to which he has added a long description from Giœni, under the word Char, in the Encyclopédie Méthodique. It is also figured as a new genus, after Pholas, in pl. 170. of the same work.

The gizzard of the $\boldsymbol{B}$. lignaria is well described and figured by Mr. Humphrey, in the second volume of the Linnæan Transactions, page 15. 
PRICKLY PIERCER.

Pl. 13. f. 1, 2, 3.

1. Pholas Dactylus. Ph. testa oblonga, hinc reticulato-striatá. Linn. Syst. Nat. ed. 12. p.1110. Linn. Gm̂nel. p. 3214.

Shell oblong, with reticulate strix.

Testa lata, ventricosa, plicis transversis striisque longitudinalibus decussata, postice reticulata. Born, Test. p. 14. t. 1. f. 7.

List. Anim. Angl. Append. t. 2. f. 3. item Conch. t. 433. f. 267. Petiv. Gaz. t. 79. f. 10. Gualt. t. 105. f. D. Seb. Mus. 3. t. 16. f. 6. a-b. Da Cost. Brit. Conch. p. 144. t. 16. f. 2. Penn. Brit. Zool. ed. 1812. vol. 4. pl. 42. f. 1. Murr. Fand. Test. t. 2. f. 3. Chemn. Conch. 8. t. 101. f. 859. Donov. Brit. Shells, t. 118. Mont. Test. Brit. p. 20. Linn. Trans. 8. p. 30.

This is a rough shell, of an oblong shape, and strongly striated both ways. The anterior end, which extends more or less into a beak, is covered with prickles running in lines from the hinge to the margin. These prickles gradually decline till they soften into striæ, which are lost towards the narrow end of the shell. The hinge is reflexed, and forms several cells on the back, as in fig. 3. These cells are covered in fig. 1. by the two striated supernumerary valves; another valve is seen in the same figure, running towards the end of the shell, between the two larger valves. There is a long curved, flattish tooth, striated towards the end, on the inside of each valve. Colour of the shell white, but often stained with ochre. It is brittle, and the lesser valves are very deciduous.

Inhabits different parts of the European seas, and shines by night. It is a common species on the coasts of France and England. Mr. Montagu found it in abundance at Salcomb, on the coast of South Devon, where it burrows in the stumps of old trees which for- 
merly grew there, but which are now covered with the tide except at very low water. The shell varies in size, and measures from one inch to six from end to end. The specimen figured in the centre of plate 13. is very perfect, and measures five inches and a half. It was found with several others at the mouth of Kingsbridge river, in Devonshire.

The best figure of the Pholas Dactylus is by Pennant. Born's figure is very good, and so is Lister's, but rather too strongly beaked. Gualtieri has evidently intended to figure the shell, but his subject must have been worn and without teeth.

\section{INDIAN PIERCER.}

\section{Pl. 14. f. 1, 2. Dr. Соомве.}

2. Pholas orientalis. Ph. testa oblonga, margine recto; altera parte glaberrima, altera reticulato-striata. Linn. Gmel. p. 3216.

Shell oblong with a straight margin; one half quite smooth, the other with reticulated strix.

Pholas India Orientalis, testa oblonga, fragili, pellucida, supra dimidium reticulatim seu decussatim striata; striis nodulosis prominulis, dorso et umbone tribus valvulis succenturiatis supertecto. Chemn. Conch. 8. p. 356. t. 101. f. 860.

List. Conch. t. 431. f. 247. Walch. Naturf. 13. p. 86. t. 3. f. 15. Encyclop. Method. pl. 168. f. 10.

A very fragile white shell, of a long narrow shape, and strongly striated on the anterior half, the other end perfectly smooth; the striæ terminate abruptly. The back of the shell, when perfect, is covered at the hinge with a single oblong valve, resembling a patella. There is a strong tooth on the inside of each valve. The shell gapes much at one end, but is nearly closed at the other. 
Inhabits the Indian ocean about Siam and Tranquebar.

The accessory valves so readily fall off, that the shell is very rarely found perfect. It is figured entire, however, by Chemnitz in a vignette, vol. 8. p. 347.

WHITE PIERCER.

Pl. 14. $f .3,4$.

3. Pholas candida. Ph. testa oblonga, undique striis decussatis muricata. Linn. Syst. Nat. ed. 12. p. 1111. Linn. Gmel. p. 3215. Shell oblong, and covered with prickly decussated striæ.

List. Anim. Angl. t. 5. f. 39. Append. t. 2. f. 4-6. Conch.

t. 435. f. 278. Gualt. Test. t. 105. f. E. Chem. Conch. 8. t. 101.

f. 861. Penn. Brit. Zool. 1812. vol. 4. pl. 42. f. 2. Donov. Brit. Shells, pl. 132. Mont. Test. Brit. p. 25. Linn.Trans. 8. p. 31.

This is a very brittle shell, decussated in all parts, except close to the cartilage on the back. The broad end nearly round, and set from the hinge to the margin, with several rows of prickles. The striæ on the other parts of the shell are all prominent, but less elevated than those at the broad end; hinge smooth, white, and reflex; a single accessory valve of a lancet shape on the back, but none on the connecting membrane below the hinge, as in the $\boldsymbol{P}$. Dactylus. Inside smooth, and glossy white, with a thin curved tooth in each valve; the thick lip above each tooth terminates in a horizontal, folded process, curved towards the cartilage. Colour yellowish white. Breadth, or from end to end, from one inch to two and a half, or three inches.

Inhabits the European and American seas. It is not an uncommon shell on some parts of the British coast. but is not often found perfect. 
The figure of this shell by Gualtieri is so indifferent as hardly to deserve a place among the synonyms.

\section{RIBBED PIERCER.}

Pl. 15. f. 1, 2. Mrs. Mawe.

4. Pholas costata. Ph. testa ovata, costis elevatis striata. Linn. Syst. Nat. ed. 12. p. 1111. Linn. Gmel. p. 3215.

Shell oval, with raised striated ribs.

Testa lata, ventricosa, transverse striata, costis longitudinalibus, extimis acutis remotioribus. Born, Test. p. 15.

List. Conch. t. 434. f. 27\%. Gualt. Test. t. 105. f. G. Knorr, Vergn. 2. t. 25. f. 4. Chemn. Conch. 8. f. 863 . Favanne, pl. 60. c. 1. Encyclop. Method. pl. 169. f.1, 2.

This shell is of an oblong oval shape, gaping at both ends. It is a strong species, ribbed regularly from one end to the other; the ribs are oblique and somewhat spinous, especially at the broad end, where they are farther apart, and scalloped at the margin. The hinge is reflex, and has an additional fold which is spread thinly on the back of the shell; there is a strong curved tooth in each valve; the slope from the hinge towards the tip of the shell is free from ribs. This shell is of a cream colour, and measures from three to six inches from end to end.

It inhabits America, and, according to Linnæus, is found among rocks in the South of Europe; but the finest specimens are from the East Indies. 


\section{CURLED PIERCER.}

$$
\text { Pl. 15. f. 3, 4, } 5 .
$$

5. Pholas crispata. Ph. testa ovali, hinc obtusiore, crispato-striata; cardinis dente curvo. Linn. Syst. Pat. ed. 12. p. 1111. Linn. Gmel. p. 3216.

Shell oval, one part more obtuse, with waved striæ; hinge with a curved tooth.

Testa utraque extremitate maxime hians. Sulcus transversus in duas partes valvulas dividens; parte altera valde rugosa, et crispa, in qua ad cardinem margo reflexus. Linn. Faun. Suec. n. 215.

List. An. Angl. t. 5. f. 38. - Append. t. 2. f. 7. Conch. t. 436. f. 279. Petiv. Gazoph. t. 79. f. 13. Penn. Brit. Zool. ed. 1812. vol. 4. pl. 43. f. 2. Da Costa, Brit. Conch. p. 242. pl. 16. f. 4. Chem. Conch. 8. t. 102. f. 872--874. Encyclop. Method. pl. 169. f. 5, 6, 7. Donov. Brit. Shells, t. 62. Mont. Test. Brit. p. 23. Linn. Trans. 8. p. 32.

The $\boldsymbol{P h}$. crispata is at once distinguished from every other species of the genus, by a transverse groove, which runs from the hinge to the margin, and divides the shell into two nearly equal parts. This groove has a corresponding elevation on the inside of each valve. The shell is strong, and very open at both ends; one part is smooth, except some faint transverse strix, but the other portion is strongly marked with subspinous undulations, which terminate rather abruptly before they reach the transverse groove. The hinge is smooth and reflex, forming a furrow towards the beak of the shell. There is a plain curved tooth in each valve. The general colour white, or ferruginous. Length from one to two inches; breadth from two to three inches. Burrows in clay or lime-stone. Inhabits the Northern ocean, and is found not uncommonly on several parts of the British coast.

We are indebted to the accurate Lister for the first VOL. I. 
figure of this shell, who has given an excellent representation of the interior, in his Hist. Anim. Angl. Gmelin has described the shell again in p. 3228, under the name of Solen crispus, with a reference to Lister, and the following query, An distincta satis hujus generis species?

\section{SMALL PIERCE-STONE.}

6. Pholas parva. Ph. testa ovali, hinc reticulato-striata, cardinis dente ex tuberculo orto. Linn. Trans. 8. p. 33.

Shell oval with reticulate striæ at one end; hinge with a tooth springing from a tubercle.

Penn. Brit. Zool. ed. 1812. pl. 43. f. 1. Mont. Test. Brit. p. 22. t. 1. f. 7,8 .

This is evidently a distinct species, rescued from a state of uncertainty by Mr. Montagu. It has been confounded both with the $\boldsymbol{P h}$. Dactylus, and Ph. crispatus, but chiefly with the latter; it differs however from both. "From the former," says Mr. Montagu, "it may be readily known by not having any cells on the reflected margin of the hinge; from the latter in not having the longitudinal furrow; and from both by the knob at the base of the tooth."

The author is in possession of a specimen an inch and a half broad, in which the above observations are confirmed, with this addition, that the margin near the beak, or narrow end, projects at a right angle with the shell, and is indented beneath.

The Pholas parvus, which Donovan has figured in pl. 69, is certainly a young shell of the Ph. crispata. 


\section{STRIATED PIERCER.}

Pl. 16. f. 1, 2, 3, 4. \& 8. Mrs. Mawe.

7. Pholas striata. Ph. testa oblonga, rotundata, multifariam striata. Linn. Syst. Nat. ed. 12. p. 1111. Linn. Gmel. p. 3215.

Shell oblong, rounded, variously striated.

Rumph. Mus. t. 46. f. H. Petiv. Amboin. t. 19. f. 8. Gault. Test.

t. 105. f. F. Speng. Besch. Berl. Naturf. 4. t. 5. f. 1-5. Phil.

Trans. vol. 55. pl. 1. f. 1, 2, 3, 4. Chemn. Conch. t. 102. 867---871.

Encyclop. Method. pl. 170. f. 1, 2, 3. Donov. Brit. Shells, t. $11 \%$.

Mont. Test. Brit. p. $26 . \quad$ Linn. Trans. 8. p. 32.

This singular species of Pholas is striated in several directions. The striæ at the head of the shell, or that part which is not buried in the wood, are very distinct; and their roughened waved surface, when perfectly clean and magnified, has somewhat the appearance of fine turned ivory. The shield which covers the hinge is nearly heart-shaped, and beneath it is a narrow plate, which connects the valves. They are both seen in fig. 1. Fig. 2. represents a shell in the same position, but without the shield, to show the two milk-white teeth that project from the back of the shell. The sides, which are buried in the wood, are extremely thin, and striated in two directions. In front there are two shields, one on each side of the opening, besides a narrow plate down the middle, like that behind. The bottom is open, and in full-grown shells rather curved. There is a long, slender, curved tooth in each of the principal valves. Fig. 4. is a shell in its natural situation, enclosed in a piece of mahogany, the cavity of which is longer than the shell itself, and therefore could not have been made by any rotatory motion of the testaceous valves, as suggested by Reaumur. The spe- 
cimens represented in the wood in fig. 8. are young shells of the same species, with the aperture exposed.

There is no specific difference between the Ph. striata and Ph. pusilla. Gualtieri has figured the shell, but he has made it too broad. It was this circumstance which probably led Linnæus to make the pusilla a distinct species, but he was evidently in doubt about the matter. Some shells are shorter and broader at bottom than others. Such are those figured under the name of Ph. striata by Chemnitz, vol. 8. pl. 102. f. 864-866.

It is not an English species, but brought to us in ships from America and India.

\section{HOOKED PIERCER.}

Pl. 16. f. 5, 6, 7. Dr. Соомв.

8. Pholas falcata. Ph. testa subovata, multifariam striata, apertura patentissima, cardinis dente falcato.

Shell somewhat oval, variously striated; aperture very large; hinge with a hooked tooth.

This is a new species, distinguished by the singular conformation of its tooth, which, after curving from under the hinge in the usual manner, returns again so as to give it the figure of a pruning-hook. The aperture of the shell is very large, at the base of which, where the valves unite, there is a little projection, or nail, which proceeds from the interior of the shell, and gives stability to the union. This appendage is common to the wood-piercers, and corresponds with the external division of the striæ. The shell is much shorter and wider in proportion than the Ph. striata, but is marked externally in the same manner. 


\section{HEART-SHAPED PIERCER.}

9. Pholas cordata. Ph. testa brevi, turgida, posterius striis elevatis transversis subtilibus exarata; hiatu corduto. Linn. Gmel.p. 3216.

Shell short and turgid, finely marked behind with elevated transverse striæ; aperture heart-shaped.

Schröt. Einl. in Conch. 3. p. 544. n. 4. t. 9. f. 22-24. Encyclop. Method.pl. 169. f. 8, 9, 10 .

This species is described by Schröter as very thin and brittle; of a dirty white colour, and smooth on the fore part, except a few ridges. The tooth is minute, and concealed in the shell. It is about half an inch long, and burrows in corallines.

\section{CHILI PIERCER.}

10. Pholas Chiloensis. Ph. testa oblonga, depressiuscula; striis longitudinalibus distantibus. Linn. Gmel. p. 3217.

Shell oblong, rather depressed, with distant longitudinal striæ.

Molini Hist. Nat. Chil. p. 179.

Described only by Molini. It is five inches long, and has minute appendages. Inhabits the rocks on the coast of Chili.

\section{GAPING PIERCER.}

11. Pholas hians. Ph. testa bivalvi, alba, transverse arcuatim striata, supra connivente, medio convexa, subtus cuneiformi; apertura ovali patentissima. Linn. Gmel. p. 3217.

Shell of two valves, white, with transverse arched strix; above connivent, in the middle convex, beneath wedge-shaped; aperture oval and very large.

Chemn. Conch. 10. p. 364. pl. 172. f. 1678-1681. Spengl. Nov. Act. Soc. Dan. 2. f. 8-11.

This species is about an inch and a half long; it has 
very small teeth, and an aperture which extends twothirds the length of the shell. It inhabits the American islands, and burrows in calcareous rocks and corals.

\section{TEREDO PIERCER.}

12. Pholas Teredula. Ph. testa oblonga, alba; sutura granulata, fusca, longitudinali. Linn. Gmel. $321 \%$.

Shell oblong and white, with a longitudinal brown granulated suture. Pall. Nov. Act. Petrop. 2. p. 240. t. 6. f. 26. A. D.

This shell, according to Pallas, inhabits the Belgic shores, and penetrates timber. It is more like a portion of a Teredo than a Pholas.

Gmelin's Ph. Campechensis, p. 3215. n. 8. is too obscure to be admitted as a species. He refers to Lister, t. 432. for his authority, but the figure is not sufficiently distinct from $\boldsymbol{P h}$. candida, to be considered as specific. 


\section{BIVALVE SHELLS.}

\section{Genus 1.}

\section{Y A.}

\section{GENERIC CHARACTER.}

Animal Ascidia.

Testa bivalvis, hians utplurimum altera extremitate.

Cardo dente, plerisque uno, solido, crasso, patulo, vacuo, (nec inserto testa opposita.)

Animal an Ascidia.

Shell of two valves; in several species open at one end.

Hinge, in general, with a single solid, thick, broad tooth, not inserted into the opposite valve.

\section{GENERAL OBSERVATIONS.}

Bruguiere has separated the Mya Pictorum, M. margaritifera, and such shells as resemble them, from the Linnæan Mya, and has formed of them a new genus, under the name of Unio. The difference indeed is obvious between the hinges of the shells just mentioned, and those of the $\boldsymbol{M}$. truncata, \&c.: we shall therefore describe the two kinds under different heads; namely, shells with teeth not inserted into the opposite valve; and shells with teelh inserted into the opposite valve. There is also a difference in the animal inhabiting the two kinds of shells; the animals of the $M$. truncata, and $\boldsymbol{M}$. arenaria, bury themselves in the sand, and are, each of them, provided with a long flexible double tube, 
which they protrude above the surface of the sand, and through which they respire and take their food. The animal of the M. Pictorum, on the contrary, has no such provision; it has merely a short muscular foot, which it protrudes from the hinder part of the shell, and is the organ by which it moves its habitation from one place to another. The shell is generally found buried in sand or mud; and the animal, though an inhabitant of the water, is capable of existing even when deprived of its native element. Bosc observed them alive, in America, in hardened mud, which resisted his efforts with a spade to dig them out; it seems they had remained in this situation during three or four summer months, without any refreshment except a few slight showers.

One of the species of this genus, the $M$. margaritifera, has long been celebrated for the pearls which it has at different times produced. It is upon record, in the second volume of the Philosophical Transactions Abridged, that several pearls of great size were procured from this shell, in the rivers of the county of Tyrone and Donegal, in Ireland. One that weighed thirty-six carats was valued at forty pounds, but being foul, lost much of its worth. Other single pearls were sold for four pounds ten shillings, and ten pounds; and it is deserving of notice, that the last was sold a second time to Lady Glenlealy, who put it into a necklace, and refused eighty pounds for it from the Duchess of Ormond.

The pearl is produced by a deposition of testaceous matter on the interior coat of the shell; it is a tubercle formed at pleasure by the animal, and is generally secreted to repair the damages made by certain worms that penetrate the inside of the shell near the edge of the valves, and, working themselves a passage between 
the laminæ that compose the cover, perforate the internal silvery coat. The remedy for this evil is immediately applied; the animal secretes the material, the hole is stopped, and a pearl is formed. Linnæus, who remarked how the animal contrived to put a stop to enemies which were living at its expense, proposed to imitate the worms, and procure artificial pearls by piercing the shells with an instrument. The means which he employed were kept a secret by the Swedish government. It succeeded to a certain degree; but the number of saleable pearls produced were so inconsiderable, in proportion to the useless tubercles, that the expense exceeded the profit, and the scheme was abandoned.

There is reason to believe that the Chinese have long known the secret of producing pearls, by perforating the shells.

Pliny remarks that small red pearls are found in the Mediterranean, especially about the Thracian Bosphorus, in certain shells called mya; but he does not attempt to define the species. In nostro mari reperiri solebant, crebriùs circa Bosphorum Thracium, rufi ac parvi in conchis, quas myas appellant. (Plin. lib. ix. c. 35.) 
*. With teeth not inserted into the opposite valve.

ABRUPT GAPER.

Pl. 17. f. 1, 2. Dr. Соомве.

1. Mya truncata. M. testa ovata, postice truncata; cardinis dente antrorsum porrecto, obtusissimo. Linn. Syst. Nat. ed. 12. p. 1112. Linn. Gmel. p. 3217.

Shell oval, truncated behind; hinge with a very blunt tooth projecting forwards.

List. Conch. t. 428. f. 269. Petiver Gaz. t. 79. f. 12. Penn. Brit. Zool. 1812. vol. 4. pl. 44. Da Cost. Br. Conch. pl. 15. f. 1, 2. Chemn. Conch. 6. pl. 1. f. 1, 2. Encyclop. Method. pl. 229. f. 2. a.b. Donov. Brit. Shells, t. 92. Mont. Test. Brit. p. 32. Linn. Trans. 6. pl. 14. f. 1, 2. and 8. p. 35.

ß. List. Conch. t. 429. f. 270.

A strong, broad, truncated shell, concentrically wrinkled, and covered with a tough ochreous epidermis, which extends beyond the open end, and is the sheath through which the animal protrudes its tubular neck. The valves very concave, and turned a little outwards at the gaping end. The tooth broad and erect. Inside white, with a strong muscular depression near the superior angle at the open end. When the epidermis is removed, the shell is generally of a chalky white.

Inhabits the European seas, and is said by Fabricius to be eaten by the inhabitants of Greenland. It is not uncommon on the British coasts, and many specimens, but chiefly single valves, are thrown upon our shores. Mr. Montagu states that he has taken it alive on the coast of Devonshire, measuring two inches and a half in length, and three inches and a half in breadth.

Lister's figure in pl. 429. is evidently intended for this shell; but it varies in being less truncated than usual. The reference by Linnæus, to Gualtieri, t. 91 . f. D. is omitted the figure being very unlike the $\boldsymbol{M}$. truncata. 


\section{SAND GAPER.}

\section{Pl. 17. f. 3.}

2. Mya arenaria. M. testa ovata, postice rotundata: cardinis dente antrorsum porrecto, rotundato, denticuloque laterali. Linn.Syst. Nat. ed. 1812. p. 1112. Linn. Gmel. 1. p. 3218.

Shell oval, rounded behind; hinge with a rounded tooth projecting forwards, and a lateral smaller one.

List. Conch. t. 418, f. 262. \& t. 419. f. 263. Baster. Opusc. Subs. t. 7. f. 1. 3. Penn. Brit. Zool. 1812. vol. 4. pl. 45. Chem. Conch. 6. t. 1. f. 3, 4. Encyclop. Method. t. 229. f. 1. a. b. Pult. in Hutch. Dorset. t. 4. f. 2. Donov. Brit. Shells, pl. 85. Mont. Test. Brit. p. 30. Linn. Trans. 6. 14. f. 3, 4. \& 8. p. 35.

The $\boldsymbol{M}$. arenaria is a strong oval shell, gaping at both ends. The outside, when recent, is covered with a yellowish, or reddish brown coat, frequently marked with dark patches. It is concentrically striated, and has faint indications of longitudinal striæ, from hinge to margin; but these are not visible in all shells. The tooth is thick and spoon-shaped, with a small lateral one on the anterior side. The inside white; the narrow end turns outwards, and has a few hairs attached to the epidermis externally. The valves are connected together by a strong cartilage, which fills the cavity of the tooth.

Inhabits the European seas, and is found on sandy shores, buried to the depth of several inches, with the narrow end upwards. The animal, like that of the preceding species, has a long double tube, which it can extend, or contract, at pleasure. Their situation in the sand is known by a small hole on the surface, which betrays them to the fishermen, who dig them up for sale. They are brought to the London market 
about February, and are sold at two shillings a dozen, but are not much esteemed. The largest measure about five inches in breadth, and two inches and a half from hinge to margin. They are eaten in the neighbourhood of Southampton, where the fishermen call them old maids.

CONVEX GAPER.

Pl. 18. f. 1.

3. Mya convexa. M. testa ovata, convexa, fragili, anticè oblique subangulata; cardinis dente semiovali.

Shell oval, convex, brittle; anterior end obliquely angulated; tooth in the hinge semioval.

Donovan Brit. Shells, t. 82. (Mya declivis.)

A very light brittle shell, remarkably convex, and strongly angulated at the anterior end: the outside is concentrically striated, and covered with an ochreous coat, rather rough near the anterior edge; when deprived of this coat, the shell is perfectly white. Inside yellowish white; tooth small, oval, and projecting horizontally.

This species is certainly distinct from the following, which is a much stronger and flatter shell. Its remarkable convexity has induced the author to give it the trivial name of convex gaper. Donovan has evidently figured this shell, under the name of $M$. declivis. It is found on the coast of Devonshire. 
SLOPING GAPER.

Pl. 18. f. 2, 3.

4. Mya declivis. M. testa ovata, compressiuscula, anticè subtruncata, cardinis dente crasso. Linn. Trans. 8. p. 36.

Shell oval and flattish, somewhat truncated at the anterior end; hinge with a thick tooth.

Penn. Brit. Zool. vol. 4. p. 160. Pult. in Hutch. Dorset. p. 27. t. 4. f. 6. Mont. Test. Brit. p. 40. (M. pubescens.)

That the $\boldsymbol{M}$. pubescens of Montagu is the $\boldsymbol{M}$. declivis of Pennant, there is but little reason to doubt. The full-grown shell, fig. 2. is strong, and covered, externally, with a rough epidermis, like shagrin. One valve is much deeper, and somewhat larger than the other, so that when the shell is closed, the edges of the valves are not together. The interior of the shell is white; the muscular depressions near the truncated end are strong, but the lower one is not carried so far within the shell as in the preceding species. The tooth is thick, strong, and divided into two cavities by a sharp denticulation.

Fig. 3. is a young shell of the same species, very thin and brittle, of an oval shape, and white colour. It is very slightly striated concentrically, and the roughness on the outside is not apparent in small specimens. Shells of this size are not uncommon on the Devonshire coast, but large specimens such as fig. 2. have been procured only of late. It is the full-grown shell that Pennant mentions as frequent about the Hebrides, the fish of which is eaten by the gentry. 
SPOON-HINGE GAPER.

Pl. 24. f. 7, 8, 9. Mr. SowERBY.

5. Mya prætenuis. M. testa ovata, planiuscula ; cardinis dente cochleariformi. Linn. Trans. 8. p. 37.

Shell oval and flattish; hinge with a spoon-shaped tooth.

Chama prætenuis. Petiver Gazoph. t. 94. f. 4.

Donov. Brit. Shells, t. 176. Pult. in Hutch. Dorset, p. 28. t. 4. f. 7. Mont. Test. Brit. p. 41. pl, 1. f. 2.

This delicate species was first noticed by Petiver. It is oval, thin, brittle, and flat; of a whitish colour, and gaping behind; a few scarcely visible concentric striæ mark the outside of the shell; the inside is white, with a broad, hollow, spoon-shaped tooth in each valve. Large specimens are an inch long, and an inch and a half broad.

Dr. Pulteney found this shell on the sands in Poole Harbour, and on the north shore near Brownsea Isle. He also collected a few valves on the shore between Weymouth and Portland. According to Mr. Montagu, single valves are not uncommonly dredged in Falmouth Harbour, and perfect shells have been taken on the south coast of Devon.

\section{DUCK GAPER.}

6. Mya anatina. M. testa globosa, nivea, pellucida; cardinis dente primario prominente, rotundato. Linn. Gmel. p. 3221.

Shell globular, very white and pellucid; primary tooth of the hinge prominent and rounded.

Adanson Seneg. pl. 19. f. 2. (Tugon,) Chemn. Conch. 6. t. 3. f. 17, 18. Encyclop. Method. pl. 229. f. 3. a. b.

A thin but firm shell, of a round shape, gaping wide 
at one end, but closed at the other. The exterior surface is striated both longitudinally and transversely, which gives it a reticulated appearance; the mouth is round and has a thick lip; the hinge has a strong spoon-shaped tooth; the shell is of a white colour. It is rarely found in Guinea, but frequently on the African shore; abundantly, says Adanson, at the mouth of the Niger.

\section{GLOBULAR GAPER.}

Pl. 24. $f .4,5,6$. Mrs. MAWE.

7. Mya globosa. M. testa suborbiculari, globosa, hians, decussatim striata; cardinis dente cochleariformi.

Shell of a roundish shape, globular, gaping, with decussated strix; hinge with a spoon-shaped tooth.

There is a strong general resemblance between this shell and the preceding; but, upon inspection, the specific difference is readily observed, the $\boldsymbol{M}$. anatina being decussated all over, while the $M$. globosa has but little more than half its surface covered with longitudinal striæ. The thick lip is also wanting, the mouth of the $\boldsymbol{M}$. globosa terminating in a sharp reflex margin. The shell has a spoon-shaped tooth; it is very thin, and the striæ may be plainly seen on the inside.

\section{ARCTIC GAPER.}

8. Mya arctica. M. testa striata; valvis carinis duabus spinulosis; cardine edentulo. Linn. Gmel. p. 3220. Mull. Zool. Dan. Prodr. 2962.

Shell striated; valves with two somewhat spinous ridges; hinge toothless. Mya tesia striata: valvis carinis duabus spinulosis, sape obsoletis ; cardine obsolete dentato. Fabr. Fn. Groenl. p. 407. N. 408.

This shell is the size of a bean, about an inch and a 
half long, of a pale yellow without, and milk-white within; it resembles an Arca, and is rather flattish before. It is obtuse on the fore part, and rather sharp behind.

Inhabits the North seas, and is found among Alga, and other marine substances.

\section{TOOTHLESS GAPER,}

9. Mya edentula. M. testa striata, ovali, aquivalvi, ample hiante ; cardine edentulo. Linn. Gmel. p. 3220. Pall. Iter 2. p. 700.

Shell striated, oval, of equal valves, gaping widely; hinge without teeth.

This species is about an inch long, thin, white, rather worn, with about thirty-three striæ on each valve, which are farther apart at the shorter end than at the other: the hinge has a thickish reflex lip.

\section{PITCHY GAPER.}

Pl. 22. $f$. 5. Dr. Соомв .

10. Mya picea. M. testa crassa, oblonga, utrinque hiante, epidermide nigra superinduta; cardine edentulo.

Shell thick, oblong, gaping at both ends, and covered with a black epidermis; hinge without teeth.

Mya siliqua. Chemn. Conch. 11. pl. 198. f. 1934.

A strong oblong shell, decorticated about the hinge, and covered with a friable coat as black as pitch, which easily separates from the surface of the shell; inside bluish white, the cavity in each valve more or less filled with a deposition of extraneous testaceous matter; valves united by cartilage, and gaping greatly at both ends. 
Chemnitz has figured this shell from a specimen in Spengler's museum.

Its country is unknown.

\section{NICOBAR GAPER.}

11. Mya Nicobarica. M. testa aquivalvi, ovato-oblonga, decussatim striata; cardinis dente solitario, lato, perpendiculari, cochleariformi. Linn. Gmel. p. 3221.

Shell of equal valves, snowy, oblong oval, with decussated striæ; hinge with a single, broad, perpendicular, and spoon-shaped tooth.

Mya candida India orientalis, testa oblonga, antice angulata, postice rotundata. Chemn. Conch. 6. pl. 3. f. 17, 18.

The valves of this shell are on one side convex, broad, and rounded at the margin; on the other more angular, narrow, flat, and gaping. The tooth is large, and the shell is about an inch and a quarter long, and an inch and three quarters broad.

It inhabits the Nicobar Islands.

\section{BEAKED GAPER.}

12. Mya rostrata. M. testa fragilissima, alba, diaphana, membranacea, antice rostro cylindrico producto, hiante; postice tumido et rotundato; cardinis dente minuto excavato.

Shell very fragile, white, diaphanous, and membranous, the fore part produced into a cylindrical beak, the hind part round and tumid; hinge with a small excavated tooth.

Chemn. Conch. 11. p. 189. vignette C. D.

This shell is figured by Chemnitz, of a pear shape, with one end remarkably lengthened, and gaping; the valves are very thin and finely striated concentrically ; they close in all parts, except the end of the beak, and are delicately white within. 
NORWAY GAPER.

Pl. 18. f. 4, 5. Mr. SowerB

13. Mya Norwegica. M. testa ovali, longitudinaliter dense striatu, altero fine rotundata, altero truncata, natibus decorticatis. Linn. Gmel. p. 3222.

Shell oval, closely striated longitudinally; one end rounded, the other truncated.

Chemn. Conch. 10. pl. 170. f. 1647, 1648.

In the shell represented in $\mathrm{pl}$. 18. the coat is wanting, and therefore the longitudinal striæ are not so visible as in the figure by Chemnitz. The inside of the shell is pearly, and there is a triangular piece like enamel in the cavity of the hinge, which does not appear, like a tooth, to be permanent. The shell is near an inch long, and an inch and three quarters broad. It inhabits Norway.

\section{MEMBRANOUS GAPER.}

14. Mya membranacea. M. testa ovata, membranacea, candida; margine ad proboscidem protracto, reflexo. Linn. Gmel. p. 3222. Mull. Zool. Dan. Prodr. 2964.

Shell oval membranaceous, and white; margin, at the beak, prolonged and reflex.

Olaff. Isl. Res. 901. t. 11. f. 10.

This is an oval shell, about the size of a bean, with a plain hinge without any appearance of teeth. It inhabits the coast of Iceland.

\section{DEFORMED GAPER.}

15. Mya distorta. M. testa subovali, valvulis difformibus, tumidioribus; cardinis dente crasso. Linn. Trans. 8. p. 37.

Shell suboval, valves tumid and deformed; hinge with a thick tooth. Mont. Test. Brit. p. 42. t. 1. f. 1.

A thin, brittle, white shell, with convex valves of a 
rugged appearance, and more or less indented at the margin. Inside white, with a broad somewhat triangular tooth in each valve. The shell in some degree resembles the $\boldsymbol{M}$. pratenuis, but the margin is waved, and the end is not truncated as in that species. It is about three quarters of an inch long, and an inch broad.

Mr. Montagu found it lodged in hard limestone at Plymouth, into which it had bored like a Pholas; and which he thinks was probably the occasion of its distorted growth.

\section{DOUBLE-TOOTHED GAPER.}

16. Mya bidentata. M. testa subovali, compressa, cardinis dentiuus antrorsum porrectis, obliquis., Linn. Trans. 8. p. 41.

Shell somewhat oval, teeth at the hinge projecting forwards, oblique. Mont. Test. Brit. p. 44. Penn. Brit. Zool. 1812.-4. p. 166.

A very small species, an eighth of an inch long, and somewhat more in breadth. Of a dirty white colour, compressed, and smooth; two broad diverging teeth in one valve, but none in the other.

This was found by Mr. Montagu, burrowed in old thick oyster shells from Salcomb Bay, Devonshire.

\section{DECUSSATED GAPER.}

17. Mya decussata. M. testa ovata, decussata; margine undata. Shell oval, decussated; margin waved.

Mont. Test. Brit. Suppl. p. 20. pl. 28. f. 1. Penn. Brit. Zool. 1812.

4. p. 167.

A white oval shell, with irregular concentric ridges decussated by regular longitudinal striæ, which form tubercles at the anterior end; the margin is waved. Inside white, with a broad erect tooth in one valve, and a projecting indented plate in the other. 
This is a new species, for which, with many more, we are indebted to Mr. Montagu, who received it from the Frith of Forth.

\section{PURPLE GAPER.}

18. Mya purpurea. M. testa ovata, transverse rugosa; cardinis dente erecto, solitario.

Shell oval, transversely wrinkled; hinge with a single erect tooth.

Mont. Test. Brit. Suppl. p. 21. Penn. Brit. Zool. 1812. 4. p. 167.

An oval shell, slightly wrinkled transversely; of a whitish colour, with a purple beak. There is a single erect tooth, slightly notched, in each valve.

This is a minute species, not above the twelfth part of an inch long. Discovered amongst corallines on the Devonshire coast, by Mr. Montagu.

\section{RUSTY GAPER.}

19. Mya ferruginosa. M. Testa subovali, obsolete rugosa ; cardinis dentibus duobus porrectis.

Shell somewhat oval, with obsolete wrinkles; hinge with two projecting teetb.

Mont. Test. Brit. Suppl. p. 22. t. 26. f. 2. Penn. Brit. Zool. 1812. p. 167.

The beak of this shell is obtuse, and placed nearest to one end ; the colour is white, but the shell is usually covered with a rusty coat which is thick and tenacious. The inside is white, and the hinge has two projecting teeth, separated by a large triangular notch.

This shell was found on Belton Sand, near Dunbar, in Scotland, and is about a quarter of an inch long, and nearly twice as broad. 
GLOSSY GAPER.

20. Mya nitens. M. testa ovata, concentrica, striata; cardine unidentato. Shell oval, striated concentrically; hinge with a single tooth.

Mont. Test. Brit. Suppl. p. 165. Penn.Brit. Zool.1812. vol.4. p. 168.

An oval glossy shell, of a pink and white colour, regularly striated concentrically. The inside is of the same colour as the outside, but not so glossy. The single tooth in one valve shuts into a deep cleft in the other. Length hardly a quarter of an inch; breadth rather more.

Mr. Montagu obtained this species from the Scottish coast, near Dunbar, but observes that it is extremely rare.

\section{PRISMATIC GAPER.}

21. Mya prismatica. M. testa oblonga, alba, anterius rostrata; cardinis dente subcochleariformi.

Shell oblong, white, beaked before; hinge with a somewhat spoon-shaped tooth.

Mont. Test. Brit. Suppl. p. 23. pl. 26. f. 3. (Ligula prismatica.)

This is a small white shell, three-eighths of an inch long, and twice as broad. It is flat, and thin, and the fore part is produced into a small beak; the outside is obsoletely striated concentrically, and the inside is smooth and glossy: the hinge, in each valve, has a broad horizontal tooth, besides one which is erect; and one of the valves has lateral laminx.

Mr. Montagu, to whom we are wholly indebted for the description of this species, received it from Belton Sands, near Dunbar, in Scotland, and from the sands between Porto Bello and Musselburg. A single valve has also been found on the coast of Devonshire. 
It derives its trivial name from its property of reflecting, in particular lights, strong prismatic colours.

\section{SUBSTRIATED GAPER.}

22. Mya substriata. M. testa subovali, alba, subpellucida, longitudinaliter obsolete striata.

Shell suboval, white, subpellucid, with obsolete longitudinal striæ. Mont.Test. Brit. Suppl. p. 25. (Ligula substriata.)

The outside is marked with distant elevated striæ; the inside is plain and the margin smooth; the hinge has a slight projection inwards. The shell measures one-tenth of an inch in diameter. It was discovered, among corallines, by Mr. Montagu, on the coast of Devonshire. It is extremely rare.

\section{DUBIOUS GAPER.}

Pl. 25. f. 2, 3. Dr. CoOMB.

23. Mya dubia. M. testa subovali, hiante; cardinis dente obsoleto. Linn. Trans. 8. p. 33.

Shell gaping and suboval; hinge with an obsolete tooth.

Penn. Br. Zool. 1812. vol. 4. p. 165, pl. 47. Da Costu, Brit. Conch. p. 234. Chama parva. Donov. Brit. Shells, t. 108. Pult. in Hutch. Dorset, p. 27. t. 1. f. 11. Mont. Test. Brit. p. 28. item Suppl. p. 20. M. Pholadia.

It has been doubted whether this shell does not belong to the genus Pholas; but Dr. Maton very properly remarks, that, notwithstanding its habits and appearance are like those of a Pholas, it wants the essential characters of that genus, viz. the accessory valves, and therefore must be necessarily placed among the Myad.

The shell is of a light brown colour, thin, brittle, opaque, and marked with fine concentric striæ; the 
beak is prominent, and placed very near the end of the shell; when the valves are closed, the gape or opening appears very large, and shows the hinge with its rudiments of teeth.

This species is found, according to Mr. Montagu, on the Dorset coast, at Torbay, and at Plymouth, burrowed in detached pieces of lime-stone; and its chamber is often lined with shelly matter, that sometimes protrudes, like a tube, a quarter of an inch beyond the stone. Mr. Montagu has specimens of this Mya, not only in lime-stone, but also in fluor, and in granite!

\section{WHITE NORWAY GAPER.}

24. Mya nitida. M. testa ovali, alba, lavi; cardinis utriusque dente obtuso. Linn. Gmel. p. 3222.

Shell oval, white and smooth; hinge with an obtuse tooth in each valve. Muller, Zool. Dan. Prodr. 2963.

Described only by Muller. Inhabits Norway.

*** With teeth inserted into the opposite valve.

DUTCH GAPER.

Pl. 19. f. 1, 2. Mr. Sow ER X.

25. Mya Batava. M. testa subovali, utraque extremitate rotundata. Linn. Trans. 8. p. 37.

Shell of a suboval shape, rounded at both ends.

Schröt. Flussconch, t. 3. f. 2. 4 \& 5. Chemn. Conch. 6. t. 1. f. 6. Encyclop. Method. t. 248. f. 2. Donov. Brit. Shells, t. 174. M. Pictorum. Mont. Test. Brit. p. 36.

This shell has been confounded with the true $M$. Pictorum, but may be distinguished by its shape, which is always less pointed at the apex, and generally less prominent at the beak, than in the M. Pictorum. It is 
an olive green shell inclining to brown, with a pearly inside, and a broad crenated tooth in each valve, besides two lateral laminæ, or plates, in one valve, and one in the other, which lock together, and form the hinge. Both ends of the shell are rounded, and in this it principally differs from the following species.

It is common in Holland, and used by the Dutch painters to contain a preparation of gold and silver leaf. In England it is considered as a rare shell; noticed by Mr. Montagu, in the river Kennet, above the town of Newbury in Berkshire, but no where else.

\section{PAINTERS GAPER.}

Pl. 19. f. 3, 4 .

26. Mya Pictorum. M. testa ovata, cardinis dente primario crenulato, laterali longitudinali, alterius duplicato. Linn. Syst. Nat. ed. 12. p. 1112. Linn. Gmel. p. 3218.

Shell oval, hinge with a crenated primary tooth; a long lateral tooth in one valve, and two in the other.

List. Anim. Ang. t. 2. f. 4. —-Append. t. 1. f. 4. Conch. t. 146. f. 1. 147. f. 3. Petiv. Gaz. t. 93. f. 9. Schröter Flussconch. t. 3. f. 3. and t. 4. f. 6. Penn. Brit. Zool. 1812. v. 4. pl. 46. f. 1. Da Cost. Brit. Conch. p. 228. pl. 15. f. 4. Encyclop. Method.pl.248. f. 4. Donov. Brit. Shells, pl. 89. Mont. Test. Brit. p. 34. (Mya ovalis.) Linn. Trans. 6. pl. 14. f. 7, 8,9. and 8. p. 38.

This shell is of an oblong-oval shape, and longer in proportion than the $\boldsymbol{M}$. Batava. It is covered with a green epidermis, striated concentrically, which, in old shells, is almost black. In young shells, the epidermis is often wrinkled near the hinge, which part in old shells is sometimes decorticated. The inside is pearly, and the hinge is furnished with teeth of the same form as in the M. Batava. The valves shut close in front, but are a little open at each end. 
This is not an uncommon shell in many parts of Europe; but it was first described and figured, as English, by Lister, and is a frequent inhabitant of the Thames, and other rapid rivers. It is used, like the preceding species, to hold colours, and from that circumstance, has received the name of Painters Gaper.

\section{OVAL GAPER.}

Pl. 19. f. 5. Mr. SowERBY.

27. Mya ovata. M. testa ovata, antrorsum angustata. Linn. Trans. 8. p. 39.

Shell oval, narrow before.

List. Anim. Angl. App. f. 6. Donov. Brit. Shells, t. 101. (M. depressa.) and t. 122. Mont. Test. Brit. p. 34. and p. 563. Linn. Trans. 8. p. 39.

This is a thick shell, narrower than the M. Batava, but broader than the $\boldsymbol{M}$. Pictorum. It is covered with a green epidermis, which varies to a dark brown, and is striated concentrically; there are, in many specimens, obsolete rays running from the hinge to the margin. The hinge, like that of the two preceding species, has a large crenated tooth, besides a long lateral one, in one valve, and two lateral teeth in the other. The difference between these three species of shells, about which there have been so many contradictory opinions, can in no way be so clearly established as by figures; we have therefore endeavoured to exhibit good specimens of each, that their respective peculiarities may be readily distinguished.

The $M$. ovata inhabits the fresh waters of different parts of Europe, and is found in England, in the rivers Froome and Avon, in Somersetshire, and in the New River, near London. 
THICK GAPER.

Pl. 20 and 21. Mr. JENNINGS.

28. Mya crassa. M. testa ovata, antrorsum angustata, umbonibus decorticatis.

Shell oval, narrow before, umbones decorticated.

A thick shell covered with a rough dark brown epidermis, except near the hinge, where it is completely decorticated. The shell is truncated towards the cartilage slope, and undulated from the hinge to near the margin. The margin is smooth. The inside is pearly, and the hinge is furnished with a very strong crenated tooth, which fits into a similar depression in the opposite valve; the lateral teeth are extremely thick and rough; there are two in one valve and one in the other. The muscular depressions are deep and crenated. This massy shell, figured from a specimen in the splendid cabinet of Mr. Jennings, weighs a pound and six ounces, and measures three inches and a half in length, and six inches in breadth. Its country is unknown.

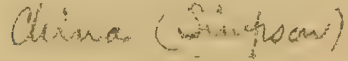

K NOTTED GAPER.

Pl. 22. $f .1,2,3,4$. Mr. JENNINGS:

29. Mya nodulosa. M. testa subovali, valrulis nodulosis; cardinis dente crasso, crenulato.

Shell somewhat oval, valves knotted; hinge with a thick crenated tooth,

This species is remarkable for the knots with which the outside of each valve is studded. In some places these knots are perfectly distinct, but near the margin they unite, and form waved ridges. This shell is of a bottle-green colour, and more or less decorticated about the hinge. The inside is pearly, and the teeth, like 
those of the preceding species; are rough and clumsy. Fig. 3, and 4, are a variety of the shell, somewhat differing in shape, but the same in every other respect as the larger one; perhaps the difference is owing merely to age. This species is remarkably thick. Its country is unknown.

PEARL GAPER.

Pl. 23. f. 1, 2, 3.

30. Mya margaritifera. M. testa ovata, anterius coarctata; cardinis dente primario conico, umbonibus decorticatis. Linn. Syst. Nat. ed. 12. p. 1112. Linn. Gmel. p. 3219.

Shell oval, compressed on the fore part; primary tooth of the hinge conic, umbones decorticated.

Mya testa ovali-oblonga, apertura sinuata, natibus decorticatis. Mull. Zool. Dan. Prodr. 2961.

List. Anim. Angl. App. t. 1. f. 1. Conch. t. 149. f. 4. Knorr. Vergn. 4. pl. 25. f. 2. Schröt. Flussconch. t. 4. f. 1. Born. Test. p. 21. Penn. Br. Zool. 1812. pl. 46. f. 2. Da Cost. Brit. Conch. pl. 15. f. 3. Chemn. Conch. 6. t. 1. f. 5. Encyclop. Method. pl. 249. f. 5. Donov. Brit. Shells, t. 73. Mont. Test. Brit. p. 33. Linn. Trans. 8. p. 40.

The $M$. margaritifera is a strong oblong-oval shell, covered with a thick, black epidermis. It is always more or less decorticated about the hinge, and frequently worm-eaten; the epidermis is concentrically striated, and rather overlaps the margin. The inside is of a bluish green colour, and pearly lustre; the hinge has a prominent tooth in one valve, which locks into a corresponding sulcus in the opposite valve; the muscular depressions are very strong and rugged, particularly the one next the hinge.

This shell is confined to the rapid rivers of northern climates. It is found within the Arctic circle, in Lap- 
land, Sweden, Norway, Saxony, and England. Mr. Montagu mentions it as common in the rivers of Devonshire which take their rise from the mountains of Dartmoor, and adds that it is not uncommon in the northern parts and in Wales.

It is this shell which occasionally produces pearls, as has been already observed, in the general observations to the genus Mya. The shell represented in the upper figure of pl. 23, has been selected for the purpose of showing the usual situation of the pearls in these shells, though they are sometimes found more towards the centre.

\section{WRINKLED GAPER. \\ Pl. 24. $f .1,2,3$. Mrs. MAWE.}

31. Mya corrugata. M. testa rhombea, vividi; umbonibus rugosis. Linn. Gmel. p. 3221. Mull. Hist. Verm. p. 214.

Shell rhombic, green; umbones wrinkled.

Testa ovali viridescente, umbonibus corrugatis, sive rugosis. Chemn. Conch. 6. pl. 3. f. 22. a. b.

Schröter Flussconch. t. 9. f. 3. Encyclop. Method. pl. 248. f. 6.

This shell is of a grass-green colour, remarkably corrugated near the hinge, and radiated down the sides. It is thin, pellucid, and whitish, beneath the epidermis; the inside is marked with fine radiated striæ; the teeth of the hinge resemble those of the $M$. Pictorum. It inhabits the rivers of Coromandel, and is from threequarters, to an inch and a half broad. 
RADIATED GAPER.

32. Mya radiata. M. testa cequivalvi, pellucida, tenuissime transversim striata, viridi flavicante, livido-radiata; valvis altero latere latissimis, altero angustissimis. Linn. Gmel. p. 3220.

Shell of equal valves, pellucid, finely striated transversely, yellowish green with livid rays; valves very broad on one side, and very narrow on the other.

Chemn. Conch. 6. t. 2. f. 7. Encyclop. Method. pl. 248. f. 5.

$\beta$. Musculus latior subfuscus, caruleis lineis radiatus. List. Conch. t. 152. f. 7.

This shell has much the habit of the $\boldsymbol{M}$. Batava, but is broader, thinner, and more fragile. It is of a green colour, decorticated about the hinge, and is regularly rayed from hinge to margin. The primary tooth of the hinge is crenated; the inside clay coloured. Inhabits the rivers of Malabar.

Lister has figured a brownish shell, with blue radiate lines, which appears to be a variety of this species.

\section{ROUGH GAPER.}

33. Mya rugosa. M. testa ovali, rugosa, extrinsecus virescente, intus margaritacea; cardinis dente primario crenulato, laterali longitudinali, alterius duplicato. Linn. Gmel. p. 3222.

Shell oval, wrinkled, on the outside greenish, within pearly; primary tooth of the hinge crenulated, lateral teeth long, in one valve double. Chemn. Conch. 10. pl. 170. f. 1649.

This shell is described only by Chemnitz. It is about an inch long, and an inch and three-quarters broad. It is prettily wrinkled on the outside, and is found in the rivers on the coast of Coromandel. 


\section{KNOBBED GAPER.}

34. Mya nodosa. M. testa ovali, tenera, virescente, natibus nodulosis. Linn. Gmel. p. 3222.

Shell oval, thin, greenish; umbones knobby.

Chemn. Conch. 10. pl. 170. f. 1650.

This is a green, fresh-water shell, smooth in every part, except near the hinge, where a few knobs, or protuberances, appear. Its country is not mentioned.

\section{SPURIOUS GAPER.}

35. Mya spuria. M. testa rhombea, viridi; umbonibus glabris. Linn. Gmel. p. 3222.

Shell rhombic, green; umbones smooth.

Schröt. Conch. 2. pl. 7. f. 5. Favanne Conch. t. 62. f. 11. Encyclop. Method. pl. 249. f. 3.

This is a green shell, resembling in shape the $\boldsymbol{M}$. corrugata, but is nearly twice as large, and smooth about the hinge. We have Schröter's authority for its specific distinction. It inhabits the rivers of Tranquebar.

ANGULAR GAPER.

36. Mya syrmatophora. M. testa ovata, depressa ; cardinis margine ad dentem primarium mucrone subulato, altero dilatato. Linn. Gmel. p. 3222.

Shell oval, depressed; margin of the hinge with an-awl shaped projection near the primary tooth, that of the other valve dilated.

Gron. Zooph. pl. 18. f. 1. 2.

This species is about two inches and a quarter long, and two inches broad. Gronovius describes it as having marginal teeth on each side, with parallel duplicatures. It is nearly of a triangular shape. Inhabits the rivers of Guinea. 
ROUNDISH GAPER.

37. Mya suborbicularis. M. testa suborbiculari, valvula alterius dente primario solitario, alterius duplicato, dentibus lateralibus lamellatis. Linn. Trans. 8. p. 41.

Shell roundish, a single primary tooth in one valve, a double one in the other, lateral teeth laminated.

Mont. Test. Brit. p. 39. item. Suppl. pl. 26. f. 6.

This is a yellowish-white shell, frequently covered with a brown epidermis, and faintly striated transversely; the inside glossy white.

Mr. Montagu, to whom we are indebted for the knowledge of this species, discovered it at Plymouth, in hard lime-stone. He adds, that it is sometimes dredged up, free of any extraneous substance, in Salcomb Bay, Devonshire. It very strongly resembles the Tellina cornea, but is not a fresh-water shell.

\section{VARIABLE GAPER.}

38. Mya variabilis. M. testa subrhombea, gibbosa, umbonibus longitudinaliter corrugatis, cardinis dentibus duobus, apice divergentibus, foveis linearibus invicem insertis. Linn. Trans. 10. p. 327. t. 24. f. $4,5,6,7$.

Shell somewhat rhombic, gibbous, umbones longitudinally wrinkled; hinge with two teeth diverging at the apex, and inserted into corresponding linear cavities.

This is one of the seven new species of Testacea, described and figured by Dr. Maton, in the tenth volume of the Linnæan Transactions. It is striated transversely, and the longitudinal wrinkles disappear towards the middle of the shell. The outside is brown; the inside pearly, and bluish. The margin is somewhat angular before, and forms a straight line at the hinge. The shell is about an inch long, and rather 
less in breadth. Young shells are smaller, of a purple colour within, with prominent wrinkles diverging from the apex, nearly to the margin.

Dr. Maton describes this shell as varying so extremely in its structure and contour, according to its several stages of growth, that if he had not been able to compare them in their intermediate ages, he should probably have been led to consider them as distinct species; a mistake which has often originated, as the Doctor very justly remarks, from the want of similar opportunities.

It is a fresh-water shell, and inhabits the Rio de la Plata, in South America.

\section{LIPPED GAPER.}

39. Mya labiata. M. testa subovali, valvis occlusissimis, alterius margine labii instar prominente. Linn. Trans. 10. p. 326. t. 24. f. 1, 2, 3. Shell suboval, valves shut close, with one margin projecting like a lip.

A strong shell, with a green epidermis, transversely striated, the fore part is somewhat beaked; the inside is pearly and shining. The hinge has a solid, projecting tooth, in one valve, which is rather spoon-shaped, and fits into a triangular cavity in the opposite valve; the umbones are very slightly prominent.

This shell described with the above by Dr. Maton, was also received, through the medium of the Right Hon. Sir Joseph Banks, from the æstuary of the Rio de la Plata. The specimen from which the characters were taken, measures about an inch in length, and rather more than half an inch in width. Its most striking characteristic is the inequality of its valves, part of the margin of one valve, projecting over the corresponding part of the other, so as, exactly to re- 
semble a lip. In this particular it bears some resemblance to the following species, which derives its trivial name from the inequality of its valves.

\section{UNEQUAL-VALVED GAPER.}

40. Mya inæquivalvis. M. testa subtriangulari; umbonibus incurvatis, gibbis. Linn. Trans. 8. p. 40. t. 1. f. 6.

Shell somewhat triangular; umbones convex and curved inwards.

Walker Test. Minut. Rar. pl. 3. f. 85. Encyclop. Method.pl. 230. f. 4. a. b. Mont. Test. Brit. p. 38. item. Suppl. pl. 26. f. 7.

This is a small species, which seldom equals half an inch in breadth. It is thick, rough, of a dirty white colour, and has dissimilar valves, the upper one being smaller and not so deep as the other. The lower valve projects, on the fore part, into a beak, and is strongly striated concentrically; the upper valve is marked also in the same manner, and has besides a few distant longitudinal striæ. It is generally covered with a brown epidermis. There is a strong triangular tooth in one valve, which fits into a notch in the other. There are no lateral teeth.

Single valves of this shell are common on the Sandwich shore, but perfect shells are seldom obtained unless dredged from the deep. Mr. Montagu noticed it on the coasts of Cornwall and Devonshire, and procured live specimens in Salcomb Bay.

Bruguiere has placed this shell in a new genus, under the name of Corbula. 


\section{GREAT GAPER.}

Pl. 25. $f$. 1. Mrs. Maw E.

41. Mya Glycimeris. M. testa utrinque hiante, crassissima, lamellata, oblongo-ovato, transverse striato-rugosa; cardinis dente primario crussissimo. Linn. Gmel. p. 3222.

Shell gaping at both ends, very thick, lamellated, of an oblong oval, with transverse wrinkled striæ; hinge with a very thick primary tooth.

List. Conch. t. 414. f. 258. Gault. Test. pl, 90. f. A. Born. Mus. p. 20. pl. 1. f. 8. Chem. Conch. 6. pl. 3. f. 25. Donov. Brit. Shells. t. 142. Linn. Trans. 8. p. 34. Mont. Test. Brit. Suppl.p. 19.

This is a very large shell, gaping greatly at both ends, and often covered, externally, with unequal waved ridges, distributed in the form of bands; it is of a yellowish, or reddish fawn colour, on the outside, and whitish within ; the hinge is strongly united by cartilage, and there is a thick tooth in one valve, which fits into a corresponding cavity in the other. The anterior, or truncated end of the specimen figured in pl. 25., is partly decomposed at the edge, where particles of the shell are formed into small globular bodies, like those calcareous concretions called Oolites.

This shell is about five inches long, and ten broad. It is found in the Mediterranean, and on the coasts of Spain, and the South of France, but never, we believe, in England, though Donovan has admitted it among the British Testacea. It is considered as an ambiguous species, connecting the Mye with the Solenes, it is placed therefore at the end of the genus.

It will be proper to observe in this place, that the Mya Perna, of Linnæus, is a muscle; and that the Mya Vulcella, is an oyster. The Mya oblonga, of Gmelin, is the Mactra hians; the Mya Gaditana, is the Mactra Listeri; and the Mya australis, is also a Mactra. The Mya byssifera, is the Mytilus rugosus. 


\section{Genus 2.}

\section{SOLEN.}

\section{GENERIC CHARACTER.}

Animal Ascidia.

Testa bivalvis, oblonga, utroque latere hians.

Cardo. Dens subulatus, reflexus, sæpe duplex ; non insertus tesłæ oppositæ.

Animal an Ascidia.

Shell bivalve, oblong, open at both ends.

Hinge with an awl-shaped reflex tooth, often double; not inserted in the opposite valve.

\section{GENERAL OBSERVATIONS.}

THE soft animal contained within the Solen, or Razorshell, has at one extremity, a muscular subcylindrical foot, and at the other a short double tube. It lives constantly buried in the sand, and never, of its own accord, comes entirely upon the surface. It is capable of moving only in a perpendicular direction, and the form of its shell, which is long and slender, is admirably calculated for such a purpose. The hole which the common species of our coasts make, is two or three feet in depth; the animal descends to the bottom, on the ebbing of the tide, and returns towards the surface as it flows. They may be seen near low water mark, 
with their bodies protruding from their shells, in search of food, but upon the approach of any one to disturb them, they immediately shrink back, and sink into the sand. They leave, on the top, a small dimple, which marks their place, and betrays them to the fishermen. A slight pinch of salt, laid upon their holes, is sufficient to make them come to the surface; and this, though often repeated, will always succeed. It has been asserted, however, as a remarkable fact, that if the animal be once handled, and afterwards suffered to retire, it can never be raised again by a similar application. They contrive to move in their perpendicular direction with great celerity, and this operation is effected by means of their foot, which is fleshy, moderately long, and nearly round. With this foot, the animal is able to bore a hole in the sand, for the passage of its shell; but the precise manner in which this is managed, though described by some authors, is likely to remain a mystery, while sand continues opaque, and Solens work in the dark.

These fish are eaten in Italy, in France, and sometimes in England. The Irish eat them during Lent. They are collected in three different ways-by enticing them to the surface with salt; by digging them out of the sand with a shovel, or by striking them with a bearded dart, while their necks are protruded in search of food.

It may be observed that the ancients, who were not backward in discovering what was fit to eat, were fond of Solens. Athæneus directs them to be boiled or fried; or, what is still better, to roast them on live coals till they gape. 


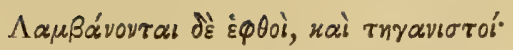

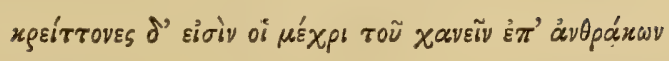
ơ $\pi \tau \omega ́ \mu \varepsilon v o เ$.

Athen. Lib. 3. p. 90.e.

The same author, in page 86 , quotes a commendation of Sophron, who not only praises them as great delicacies, but says that they are particularly grateful to widows. 
POD RAZOR.

Pl. 26. f. 1, 2. Mr. SowERBY.

1. Solen Siliqua. S. testa lineari recta; cardine altero bidentato. Linn. Syst. Nat. ed. 12. p. 1113. Linn. Gmel.p. 3223.

Shell linear, straight; hinge with a double tooth in one valve. List. Hist. An. Angl. t. 5. f. 37.-Conch. t. 409. f. 255. Plan. Conch. t. 3. f. 2. Gualt. Test. pl. 95. f. c. Knorr. Vergn. 6. pl. 7. f. 1. Penn. Brit. Zonl. ed. 1812. v. 4. p. 171. pl. 48. f. 1. Da Cost. Brit. Conch. p. 253. pl. 17. f. 5. Encyclop. Method. pl. 222. f. 2. b.c. Mont. Test. Brit. p. 46. Linn. Trans. v. 6. pl. 14. f. 10. \& v. 8. p. 43.

B. List. Conch. t. 413. f. inf. Chem. Conch. 6. pl. 4. f. 29.

A pod-shaped shell, covered with an olive-green epidermis, and striated transversely; the strixe turn across the shell, increasing from the hinge, till they reach the extremity, so as to form a triangular figure, with a pointed apex ; there is a furrow along the back, on each side of the cartilage. The inside is white, with two teeth in one valve, and one in the other; there are, besides, two remote central laminæ. The shell is straight, truncated at one end, and rounded, and turning rather outwards at the other. It measures eight inches, and sometimes more, from end to end.

This is a common shell on the different European shores, where it is collected for the sake of the fish, as has been already observed in the general observations.

The variety referred to Lister and Chemnitz, is not a straight, but a curved shell, and was named, by Dr. Solander, Solen incurvatus. 
CARMARTHENSHIRE RAZOR.

2. Solen Novacula. S. testa lineari recta, cardinibus unidentatis. Linn. Trans. 8. p. 44.

Shell linear, straight; hinge with a single tooth in each valve. Mont. Test. Brit. p. 47.

As this is evidently a new shell, and described only by Mr. Montagu, it will be but just to mark its specific difference in his own words.

"Solen with a straight sub-cylindric shell, in every respect like the Siliqua, except in the hinge, in which it is essentially different, being furnished with one strong, blunt, curved tooth, in each valve, at one end, destitute of lateral laminæ: these teeth turn contrary ways, and, when closed, clasp or hook into each other. This species may possibly have been confounded with the foregoing from its external similitude, for we do not find it noticed by any conchologist. It is found on the sandy shores of Carmarthenshire, near Laugharne, together with the Siliqua of a large size. We have taken it full an inch long, and eight inches broad; but it is extremely rare."

\section{SHEATH RAZOR.}

Pl. 27. f. 1.

3. Solen Vagina. S. testa lineari recta, extremitate altera marginala, cardinibus unidentatis. Linn. Syst. Nat. ed. 12. p. 1113. Linn. Gmel.p. 3223.

Shell linear, straight, one end margined; hinge with a single tooth in each valve.

Lister Conch. t. 410. f. 256. Penn. Brit. Zool. 1812. v. 4. p. 171. pl. 49. f. 1. Chem. Conch. 6. pl. 4. f. 27? Linn. Trans. 6. pl. 14. f. 11. Pult. in Hutch. Dorset. p. 28. pl. 4. f. 8. Donov. Brit. Shells. pl. 110.

This is a perfectly straight shell, covered with an 
orange-yellow epidermis, and often stained, in parts, of a dark brown colour, by the mud in which it is found. It is marked like the Siliqua, but without a furrow running down the back, on each side the cartilage, as in that shell. One end has a strong margin. Inside white, with a single horizontal tooth in each valve, sliding upon one another, when the shell is closed.Full-grown specimens are about five inches from end to end.

This was reckoned a scarce species in England, by Mr. Montagu, till some time previous to the appearance of his supplementary publication on the Natural History of British Shells, when he discovered a bed of them in a sand-bank, near the salt stone, in the estuary of Kingsbridge, Devonshire. Their habitations are known by a small hole on the surface, and they bury themselves to the depth of two feet, or more, beneath the sand. They have never been scarce on the shore at Sandwich, where the author has formerly picked up a considerable number in a few days.

This shell is the true Solen Vagina of Linnæus, who has particularly noticed its margined end. His references are, however, to the following shell, which cannot be considered as a variety only, since it never deviates from its particular characteristic distinction. 
TRLNCATED SOLEN.

Pl. 26. $f$. 3, 4. \& Pl. 27. f. 2. (Var. $\beta$.$) Dr. Соомв в.$

4. Solen truncata. S. testa lineari recta, extremitate altera truncata, cardinibus unidentatis.

Shell linear, straight, one end truncated; hinge with a single tooth in each valve.

Gualt. Test. t. 95. f. D. Knorr. Vergn. 1. pl. 28. Chem. Conch. 6. pl. 4. f. 28. Encyclop. Method. pl. 222. f. 1.b. Barbut's Shells, pl. 2. f. 4. ß. Rumph. Mus. pl. 45. f. M. Gualt. Conch. pl. 95. f. E. D'Argenville Conch. pl. 28. f. $\boldsymbol{K}$. Favanne Conch. pl. 55. f. B. 1.

This shell may be immediately distinguished from the preceding species, by its truncated end, which is so perfect, that it appears as if pared down by art, till the teeth are seen close to the end of the shell. There is not the vestige of a margin, in any of the many specimens which the author has had an opportunity to examine. The var. $\beta$. is shorter than the other, and somewhat tapering towards its rounded end.

It is found in the American and Indian Seas, and measures from three to seven inches, from end to end.

\section{SLENDER RAZOR.}

\section{Pl. 2\%.f. 3. Linn æan Society's Cabinet.}

5. Solen linearis. S. testa lineari recta, cylindrica, tenuissima ; cardine unidentato, extremitate quasi truncata.

Shell linear, straight, cylindrical, very thin; hinge with a single tooth in each valve, and nearly truncated.

Chem. Conch. 11. t. 198. f. 1931, 1932.

This is a very delicate shell, of a fine violet colour. The teeth, of which there is one in each valve, slide upon each other, when the shell is closed, the same as in the 
S. Vagina. The specimen figured by Chemnitz, from Spengler's Museum, measures two inches; the subject represented in $\mathbf{P l}$. 27. is three inches and a quarter, from end to end.

Inhabits the Indian Seas.

SWORD RAZOR.

Pl. 28. f. 1, 2.

6. Solen Ensis. S. testa lineari subarcuata; cardine altero bidentato. Linn. Syst. Nat. ed. 12. p. 1114. Linn. Gmel.p. 3224.

Shell linear, somewhat curved ; hinge with a double tooth in one valve.

List. An. Angl. App. pl. 2. f. 9. item Conch. t. 411. f. 257. D'Argenville Conch. pl. 24. f. 1. Penn. Brit. Zool. 1812. v. 4. pl. 48. f. 2. Da Cost. Brit. Conch. p. 237. Chem. Conch. 6. t. 4. f, 30. Encyclop. Method.pl. 223. f. 2. Schröt. Conch. 2. pl. 7. f. 7. Pult. in Hutch. Dorset. p. 28. pl. 4. f. 3. Donov. Brit. Shells. pl. 50. Mont. Test. Brit. p. 48. Linn. Trans. 8. p. 44.

The Solen Ensis is a thin, brittle shell, prettily mottled, on the outside, with brown and green. It is always curved, and most so in young shells. The inside is bluish white, and the hinge consists of a single tooth in one valve, which is inserted between two others in the opposite valve, with a prominent continuation, part of the way down the cartilage in both valves.

This species is found in the Mediterranean, and upon the northern coasts. It is not a common species in England, but is occasionally found upon our shores, and particularly at Sandwich, where many specimens have been collected at different times. 
TRANSPARENT RAZOR.

Pl. 28. $f$. 3.

7. Solen pellucidus. S. testa lineari subarcuata, dente alterius valvula bifido. Linn. Trans. 8. p. 44.

Shell linear, somewhat arched, with a bifid tooth in one of the valves.

Penn. Brit. Zool. 1812. v. 4. p. 137. pl. 49. f. 2. Chem. Conch. 11.p. 205. pl. 198. f. 1940. Donov. Brit. Shells. pl. 153. Mont. Test. Brit.p. 49.

We are indebted to Pennant for our knowledge of this fragile and transparent shell. He found it at Red Wharf, in Anglesey, and describes it as a somewhat arched and oval shell, with a hinge consisting of a sharp double tooth on one side, receiving a single one from the opposite, with a process in each valve, pointing towards the cartilage of the hinge. It is a very tender shell, covered with a shining epidermis, of a light greenish brown' colour. It seldom measures more than an inch from end to end.

Mr. Montagu found this shell in Cornwall, and some specimens have been obtained, but very rarely from Sandwich. The few that occur on the Sandwich shore, have been found at low water, in the mud, near the mouth of the haven. 
PEASCOD RAZOR.

Pl. 28. f. 4, 5. Mr. Sow ER B.

8. Solen Legumen. S. testa lineari-ovali, recta, cardinibus mediis bidentatis, alterius bifido. Linn. Syst. Nat. ed. 12. p. 1114. Linn. Gmel. p. 3224.

Shell linear-oval, straight; teeth in both valves double; in one valve bifid.

List. Conch. t. 420. f. 264. Gualt. Test. t. 91. f. A. Adans. Seneg. t. 19.

f. 3. Born Mus.pl. 2. f. 1, 2. Penn. Brit. Zool. 1812. v. 4. pl. 49.

f. 3. Da Cost. Brit. Conch. p. 238 . Chem. Conch. 6. t. 5. f. 32-34.

Encyclop. Method. pl. 225. f. 3. Pult. in Hutch. Dorset. pl. 4. f. 4.

Donov. Brit. Shells. pl. 58. Mont. Test. Brit. p. 50. Linn. Trans.

8. p. 45.

This is a delicate white shell, very finely striated concentrically, and covered with a yellowish epidermis. It is broader at one end than the other, and the narrow end is rounded, like the human nail, and inclines a little outwards. The inside is white, and the hinge, which is placed towards the middle of the shell, consists of two teeth in each valve; on one side they are erect, thin, and pointed, on the other they are thick, broad, and diverging. There is a white ridge, running from the bifurcation of the teeth, towards the middle of the shell, and another, in a contrary direction, from the edge of the hinge, towards the narrow end. It is found of various sizes, measuring from one inch and a half, to four inches, from end to end.

Inhabits the Mediterranean Sea, and Atlantic Ocean. In England the species was long considered as very rare, but it has been since found, on some shores, abundantly. Montagu met with it on the coast of Carmarthenshire, nearly an inch from hinge to margin, 
and four inches from end to end. At Tenby, it is one of the common species, and is also plentiful in Biddeford Bay, on the coast of North Devon.

\section{KIDNEY RAZOR.}

\section{Pl. 29. $f$. 1, 2. Mrs. MAwE.}

9. Solen Cultellus. S. testa ovali-oblonga, subarcuata. Linn. Syst. Nat. ed.12. p. 1114. Linn. Gmel. p. 3224.

Shell oblong-oval, somewhat arched.

Rumph. Mus. pl. 45. f. F. Petiven Gaz. pl. 1\%. Gualt. t. 9n. f. E. Chem. Conch. 6. pl. 5. f. 36, 37. Encyclop. Method.pl. 223. f. 4.

The S. Cultellus is finely striated concentrically, and covered with a brown epidermis, beneath which the shell is of a dirty white, with tawny marks. It is spotted within in the same manner, and there are two teeth in one valve, and one in the other. It is rounded at both ends, and is very brittle.

This species is found on the sandy shores of Amboyna and Tranquebar. It occurs of different sizes, from one to four inches from end to end.

\section{ANTIQUATED RAZOR.}

Pl. 29. f. 3. Dr. Соомве.

10. Solen antiquatus. S. testa ovali-oblonga, utrinque rotundata ; cardine altero bidentato.

Shell oblong-oval, rounded at both ends; hinge with two teeth in one valve.

Adans. Seneg. t. 19. f. 3. Penn. Brit. Zool. 1812. v. 4. p. 174. pl. 49. f. 4. Schröt. Flussconch. t. 9. f. 17. Chem. Conch. 6. pl. 6. f. 45. Donov. Brit. Shells. pl. 114. Mont. Test. Brit. p. 52. Linn.Trans. 8. p. 46.

This shell is of a whitish colour, covered with a yellowish-brown epidermis, and strongly striated concen- 
trically; two faint lines, without colour, diverge, in a slight degree, from the hinge to the margin. The shell gapes considerably at both ends; it is white within, and has two erect teeth in one valve, receiving one between them from the opposite side. These teeth, however, are so deciduous, that we seldom meet with a shell quite perfect. It is one inch long, or from hinge to margin, and two inches broad.

This, which is the S. coarctatus of Gmelin, is a rare species, and was first figured by Pennant, who found it at Weymouth. Mr. Montagu mentions it from Looe in Cornwall.

BRITTLE RAZOR.

Pl. 29. f. 4, 5. Dr. Соомв Е.

11. Solen fragilis. S.testa ovali-oblonga, tenui, alba, epidermide obscure viridescente superinduta, cardine altero bidentato.

Shell oblong-oval, thin, white, and covered with a dark greenish epidermis ; hinge with two teeth in one valve.

Chem. Conch. 11. pl. 198. f. 1939. (Solen bidens). Pult. in Hutch. Dorset. pl. 4. f. 5 .

A thin, delicate, white shell, covered with a strong green epidermis, except about the hinge, which is in most specimens quite bare. In the middle it is somewhat depressed, and is rounded at both ends. The principal characteristic is a strong red line, which passes from the hinge towards the margin, declining in colour as it proceeds. In the specimen under notice, faint indications of two other lines, which are perfectly white, may be perceived, in one valve, diverging from the same point. The inside is white, and the hinge, which is placed in the middle of the shell, has two teeth on one side, and one on the other. 
This shell is an inhabitant of warm climates. In the catalogue of Dr. Pulteney's shells, it is said to have been found at Weymouth, in Dorsetshire, and on Studland beach, in the same county.

\section{STRIGILATED RAZOR.}

Pl. 30. $f$. 1. Mrs. Mawe.

12. Solen strigilatus. S. testa ovali, oblique striata. Linn. Syst. Nat. ed.12. p. 1115. Linn. Gmel. p. 3225.

Shell oval, obliquely striated.

Lister. Conch. t. 416. f. 260. Bonan. Recr. 2. f. 77. Gualt. Test.pl. 91. f. C. Knorv. Vergn. 6. pl. 5. f. 4. Chem. Conch.6. pl. 6. f. 41, 42. Encyclop. Method. pl. 224. f. 3.

ß. Chem. Conch. 6. pl. 6. f. 43, 44. item 11.pl. 198. f. 1938. (S. Sanctæ Marthæ.)

This is a strong ventricose shell, round at one end, and somewhat truncated at the other. It is of a reddish colour on the outside, with two white rays diverging from the umbo to the margin, and numerous distinct striæ, passing in a curvilinear direction over the shell ; a few of these striæ cross the others at one end. The inside is white, the hinge towards the middle of the shell, and the teeth three in number, two in one valve, and one in the other. This species is subject to vary considerably; some are entirely white, without rays, and fewer striæ. Others, though coloured, are small, and also without rays, but are striated.

Inhabits the Mediterranean, the Atlantic, and the Indian Seas. 
DUCK-BILL RAZOR.

Pl. 30. $f .2,3,4$. Mr. Jennings.

13. Solen anatinus. S. testa membranacea inflata pilosa, cardinis costa falcata. Linn. Syst. Nat. ed. 12. p. 1115. Linn. Gmel. p. 3225. Shell memibranaceous, inflated and hairy; hinge with a crooked rib. Rumph. Mus. pl. 45. f. 0. Argenville Conch. pl. 22. f. $\boldsymbol{R}$. Born Test. p. 23. Chem. Conch. 6. pl. 6. f. 46-48. Encycl. Method. pl. 228. f. 3. a. b.

This is a very singular shell, pellucid, white, and thin as paper. It is much inflated, and one end resembles the beak of a duck. The hairiness mentioned by Linnæus, may exist in some states of the shell, but it has not been visible in any specimens seen by the author. There is a spoon-shaped tooth in each valve, with a curved rib running towards the interior of the shell. A delicate suture is continued a little way from the apex of the shell, which often cracks.

The $S$. anatinus inhabits the sandy shores of the Indian Ocean.

\section{RAYED RAZOR.}

Pl. 31. $f$. 1, 2. Mrs. Mawe.

14. Solen radiatus. S. testa ovali, recta, lavi; costa transversali adnata, depressa. Linn. Syst. Nat.ed. 12. p. 114. Linn. Gmel. 3225.

Shell oval, straight, and smooth, with a transversal depressed rib.

List. Conch. t. 422. f. 266. Rumph. Mus. t. 45. f. E. Gualt. Test. t. 91.

f. B. Knorr. Vergn. 1. pl. 6. f. 5. Barbut's Shells. pl. 2. f. 6.

Chem. Conch. 6. pl. 5. f. 38 - 40. Encycl. Method. pl. 225. f. 2.

A thin smooth species, gaping at both ends, and originally covered with a green epidermis, which falls off, and leaves a delicate violet shell, finely striated concentrically, and marked with four white rays, diverging 
from the apex to different parts of the margin. It is marked within, the same as on the outside, and has two teeth in each valve, with a strong, white, depressed rib, running obliquely across the shell. It is sometimes found with two white rays instead of four. Large specimens measure four inches from end to end.

Inhabits the Indian Ocean, and is found at Amboyna.

\section{GUINEA RAZOR.}

15. Solen Guineensis. S. testa alba, glabra, subpellucida, ventricosa, utrinque hiante.

Shell white, smooth, subpellucid, ventricose, gaping at both ends.

Chem. Conch. 11. pl. 198. f. 1937.

This shell is described only by Chemnitz. It is strong, smooth, and white, and resembles Adanson's Tagal, tab. 19. f. 1., but seems to be a thicker shell, with a broad hinge, and a strong rib running across the inside. The teeth are not visible in the figure represented by Chemnitz.

Inhabits the coast of Guinea.

\section{LARGEST RAZOR. \\ Pl. 31. f. 3.}

16. Solen maximus. S. testa lineari-ovali, alba, subdiaphana, utrinque hiante et rotundata; intus costa transversali a cardine ad marginem decurrente.

Shell linear oval, white, subdiaphanous, gaping, and rounded at both ends ; a transversal rib within, running from hinge to margin.

This is a flat, white shell, covered with a yellowishgreen epidermis, striated concentrically, and very glossy. From the hinge, which has two teeth in one

YOL. I. 
valve, and one in the other, there runs a strong rib, which spreads as it proceeds across the shell, and is lost near the margin; the upper part of the muscular depression is ridged, from the teeth towards the end of the shell. The specimen represented in the plate measures two inches from hinge to margin, and nearly five inches from end to end.

\section{GREAT RAZOR.}

17. Solen magnus. S. testa lineari-ovali, recta, arcuato-striata, cardinibus lateralibus bidentatis. Linn. Gmel. p. 3227. S. maximus.

Shell linear-oval, straight, with arched stria; hinges lateral with two teeth.

Chem. Conch. 6. pl. 5. f. 35. S. maximus.

This shell was considered by Chemnitz as the largest of the Solens, and named accordingly ; but the preceding species being considerably larger, it was thought proper to give to that the name of maximus, and to alter this to magnus.

The $S$. magnus is described as thin, pellucid, and white, when stripped of its yellowish epidermis; it is rounded, and gaping at both ends, and the teeth of the hinge do not shut into each other. It is an inch and a quarter from hinge to margin, and four inches broad.

Inhabits the shores of Nicobar, and is a very rare species. 
INFLECTED RAZOR.

Pl. 32. f. 1, 2. Dr. Соомв Е.

18. Solen inflexus. S. testa ovato-oblonga, utrinque hiante, margine subarcuata; cardine altero bidentato, costa transversali prominente.

Shell oblong-oval, gaping at both ends, margin somewhat arched; hinge with two teeth in one valve, transversal rib prominent.

This species, which does not appear to have been hitherto described, is of a whitish colour, finely striated concentrically, and, when recent, covered with an orange-brown epidermis. The margin is plain and inflected, and the valves, when closed, touch only at two points, the inflected part, and the hinge. There is a very faint depression running obliquely from the apex of the shell to the inargin, the impression of which is visible within. The inside is white; the hinge has two teeth in one valve, and one in the other. The transversal rib is not flattened, as in some of the preceding species, but prominent and well defined.

The specimen is in the possession of Dr. Coombe, but its country is unknown.

\section{LITTLE RAZOR.}

19. Solen minimus. S. testa lineari-ovali, recta, cardinibus lateralibus bidentatis, alterius bifido. Linn. Gmel. p. 3227.

Shell linear-oval, straight; hinges lateral, double toothed, one of them bifid.

Chem. Conch. pl. 5. 31. a.b.

This is a white, diaphanous, fragile shell, covered with a yellowish epidermis; it is rounded and gaping at both ends. The inside has two teeth in each valve, 
and a transversal rib running from the hinge to the margin. It is an inch broad, and half as long.

Inhabits Tranquebar, and is a miniature representation of the $S$. maximus.

\section{MOLINI'S RAZOR.}

20. Solen Macha. S. testa ovali-oblonga, anterius truncata; cardine altero bidentato. Linn. Gmel. p. 3226.

Shell oblong-oval, truncated before; hinge with two teeth in one valve. Molini Hist. Nat. Chil. p. 178.

We have Molini's authority only for this species, which he describes as of a brown colour varied with blue. It is six or seven inches from end to end, and inhabits the shores of Chili, where it buries itself in the sand, and contains pearls.

\section{GREEN RAZOR.}

21. Solen virens. S. testa ovato-oblonga, umbonibus tumidis. Linn. Gmel. p. 3226.

Shell oblong-oval, with tumid umbones.

This is described by Gmelin as a very brittle, diaphanous shell, with unequal valves; it is of a white colour with a greenish outside, and resembles in shape the Mya Pictorum; the tip and base are hardly closed; the hinge has two approximate teeth in one valve, but none in the other.

Inhabits Java. 
VIOLET RAZOR.

Pl. 32. f. 3. Mrs. MaWE.

22. Solen Diphos. S. testa ovali, recta, lavi; umbonibus prominentibus. Linn. Syst. Gmel. p. 3226.

Shell oval, straight, and smooth; umbones prominent.

Valent. Mus. t. 13. f. 5. Chem. Conch. 6. pl. 7. f. 53, 54. Item 11. pl. 198. f. 1933. (Solen Diphos Chinensis).

In the recent state, this shell is covered with a greenish epidermis; but, in cabinets, it is generally seen without its native covering, and is of a violet colour, with numerous rays diverging from the apex to the margin; it gapes at both ends, is rounded behind, but projecting into a beak before; the inside is wholly violet, but on the outside, the violet is mixed with white. Two white rays are figured by Chemnitz, crossing the shell obliquely from the apex; but these rays were not remarkable in our specimen. The hinge has two teeth in one valve, and one in the other.

Inhabits the Indian Ocean.

The variety described by Chemnitz, under the name of Solen Diphos Chinensis, is a rounder shell, with two very conspicuous white rays.

\section{ROSE-COLOURED RAZOR.}

23. Solen roseus. S. testa rosea, aquivalvi; cardinis dente subbifido, fovece alterius valva inserto. Linn. Gmel. p. 3227.

Shell rosy, of equal valves; hinge with a somewhat bifid tooth, inserted into a cavity in the opposite valve.

Chem. Conch. 6. pl. 7. f. 55.

This shell is of an oblong-oval shape, and, beneath its greenish epidermis, is of a faint rose colour, both within 
and on the outside. It resembles a Tellen, but is open at both ends. Length an inch and a quarter; breadth two inches and a quarter.

Inhabits the Red Sea.

STRIATED RAZOR.

24. Solen striatus. S. testa aquivalvi, transversim striata; cardinis dente unico. Linn. Gmel. p. 3227.

Shell of equal valves, transversely striated; hinge with a single tooth.

Chem. Conch. 6. pl. 7. f. 57, 58.

This shell is of an oval shape, diaphanous, very fragile, and finely striated transversely; it is of a rose colour without and within, with white rays diverging from the apex to the margin; both ends are open.

Inhabits the Nicobar Islands; is five eighths of an inch long, and about an inch broad.

\section{ZIG-ZAG RAZOR.}

25. Solen castrensis. S. testa aquivalvi, glaberrima, lineis triangularibus insignita; cardine unidentato.

Shell of equal valves, very smooth, and marked with triangular lines; hinge with a single tooth.

Chem. Conch. 11.pl. 198. f. 1935, 1936.

A thin, pellucid, white shell, of an oval shape, gaping at both ends, and very singularly marked with zig-zag lines of a purple colour. The lines appear on the inside, as well as withont. The shell is about three quarters of an inch long, and an inch and a half broad.

Inhabits the coast of Guinea. 
DOUBLE-RAYED RAZOR.

Pl. 33. $f$. 1. Mrs. MaWE.

26. Solen biradiata. S. testa ovali, aquivalvi, utrinque hiante; cardine utroque bidentato.

Shell oval, of equal valves, and gaping at both ends; hinge with two teeth in each valve.

This species is of a dull purple colour, mixed with brown, and has two white rays passing obliquely from the apex to the margin. It is, when recent, covered with a strong green epidermis, the remains of which are seen on the margin of the figure. The inside, in young specimens, is nearly white, but, in full-grown shells, excepting the muscular depressions, it is orangecoloured. The shell is open at both ends, and has two bifid teeth in each valve.

VARIABLE RAZOR.

Pl. 33. $f$. 2, 3. Mrs. MAWE.

27. Solen vespertinus. S. testa ovali-oblonga, spadiceo-radiata; cardinis sinistra valve dente solitario, duplici alterius inserto. Linn. Gmel. p. 3228.

Shell oblong-oval, with carnation rays; hinge with a single tooth in one valve, inserted between two other teeth in the opposite valve.

Born Mus. Test. pl. 2. f. 6, 7. Penn. Brit. Zool.ed. 1812. v, 4. pl. 50. f. 2. Chem. Conch. 6. pl. 7. f. 59, 60. Encycl. Method. pl. 228. f. 2. Pult. in Hutch. Dorset. p. 29. pl. 5. f. 1. Donov. Brit. Shells. pl. 41. f. 2. Montagu Test. Brit. p. 54. Linn. Trans. 8. p. 47.

An oblong-oval shell, striated concentrically, rounded at one end, and somewhat truncated at the other; it is of a pale straw colour, with carnation rays, diverging from the umbo to all parts of the shell; gapes more before than behind. The inside is yellowish white and 
glossy; the teeth are erect, two in one valve and one in the other.

This species, which is the Tellina variabilis of some authors, is subject to vary in colour, from purple to orange, and pale yellow; the rays also differ in strength, and number, some shells having the strongest rays near the beak, and others being striated on the inner margin. They vary in size from an inch to two inches, and more, in breadth.

Inhabits the Mediterranean, and the Atlantic Ocean ; it is also found in England, on the Dorset coast, at Poole and Weymouth. Mr. Montagu met with it at Falmouth in Cornwall, and, of a small size, at Kingsbridge in Devonshire; live specimens, however, are to be taken only by dredging.

SANGUINE RAZOR.

Pl. 33. $f$. 4, 5. Mrs. MawE.

28. Solen sanguinolentus. S. testa ovali, glaberrima; cardine calloso, bidentato. Linn. Gmel.p. 3227.

Shell oval, very smooth; hinge callous, with two teeth.

List. Conch. t. 397. f. 236. Knorr. Vergn. 4. pl. 3. f. 4. Chem. Conch. 6. pl. 7.f. 56. Encyclop. Method. pl. 227. f. 1.

A smooth, oval shell, of a red colour, particularly about the apex; it is rounded behind, produced, and gaping before; the inside is red, with a few faint indications of rays; the hinge has a single tooth on one side, which shuts between two others in the opposite valve. The length, or from hinge to margin, an inch and a quarter; the breadth two inches.

Inhabits the coast of Jamaica, and some other of the West-India Islands. 
SPOTTED RAZOR.

29. Solen occidens. S. testa transverse striata, ad nates g.labra, albo rubelloque radiata, cardine utroque bidentato, foveola intermedia. Linn. Gmel.p. 3228.

Shell transversely striated, smooth at the apex, with rays of a white and reddish colour; hinge having two teeth in each valve, with an intermediate cavity.

Chem. Conch. 6. pl. 7. f. 61. I2.7

This shell is finely striated transversely, and partially spotted with red and white; it is obliquely rayed from the apex to the margin; one end is rounded, the other somewhat truncated; both ends gape; the inside is white. It is about two inches and a half in length, and four inches in breadth.

Inhabits the Western Ocean.

\section{SPENGLER'S RAZOR.}

30. Solen Spengleri. S. testa natibus bipartitis; cardinis dente primario rotundato, accessoriis longis angustis; altero curvato. Linn. Gmel. p. 3228.

Beaks of the shell two-parted, primary tooth of the hinge rounded, accessary ones long and narrow, one of them curved.

Speng. Catal. Rais. pl.1. f.8, 9.

A species described only by Spengler. It is rounded at both ends; is about an inch from hinge to margin, and two inches and a half from end to end. 


\section{AMETHYSTINE RAZOR.}

Pl. 34. f. 1. Mrs. MawE.

31. Solen Amethystus. S. testa oblongo-ovata, compressa, transversim striata, utrinque hiante; cardine altero bidentato, dentibus lateralibus nullis.

Shell oblong-oval, compressed, transversely striated, and gaping at both ends; hinge with two teeth in one valve; no lateral teeth.

Knorr. Vergn. 6. pl. 12. f. 2. Chem. Conch.6. pl. 10. f. 93 . Tellina Gari.

An oblong-oval shell, of a dull purple colour, with deeper rays of the same; one end is rounded, the other somewhat truncated; both ends gape; it is striated, transversely, the striæ on the rounded end, distant; the middle of the shell is interlined. The striæ are waved over a faint ridge, which runs obliquely from the apex to the margin, on the fore part of the shell. Inside purple and white; hinge with a notched tooth in one valve, received between two others in the opposite valve; one of the two teeth is frequently wanting. An inch and a quarter long, or from hinge to margin, and two inches and a half broad.

Inhabits India.

The same reason which placed the Tellina variabilis among the Solens, will also authorise the removal of this shell to the same genus. Several specimens have been examined, and all of them are found to close in the middle, but to gape at each end. Chemnitz has referred it to the Tellina Gari, but that shell is particularly distinguished by Linnæus, as being striated obliquely, as well as transversely, which is not the case with the subject under our present consideration. It is well represented by Chemnitz. 


\section{VARIEGATED RAZOR. \\ Pl. 34. $f$. 2, 3, 4. . Mrs. MAWE.}

32. Solen variegatus. S. testa oblongo-ovata, anterius truncata, hiante ; cardine altero bidentato.

Shell oblong-oval, truncated before, and gaping; hinge with two teeth in one valve.

This elegant little shell is stained with purple and orange colour, in a singular manner. The purple passes from the umbo more than half way down the shell, and then turns forwards to cover the truncated end. In the inside, the boundary of this stain is particularly apparent. Faint and narrow rays of purple pass also from the apex to the margin, on the rounded end of the shell, which, except from this interruption, is entirely of an orange colour. The hinge has two teeth in one valve, and one in the other. The shell is thin and pellucid, and gapes at the truncated end.

\section{MINUTE RAZOR.}

Pl. 34. f. 5, 6.

33. Solen minutus. S. testa ovali, valvularum angulis utrisque serratis. Linn. Syst. Nat.ed. 12. p. 1115. Linn. Gmel. p. 3226.

Shell oval; angles of the valves serrated.

Chem. Conch. 6. pl. 6. f. 50, 51. Encyclop. Method. pl. 234. f. a. b. Mont. Test. Brit. p. 53. pl. 1. f. 4. Linn. Trans. 8. p. 47. Penn. Br. Zool. 1812. v. 4. p. 175.

This species is particularly remarkable for two rows of spines, which run from the apex to the anterior margin of the shell ; the valves are dissimilar, the under valve projecting in a slight degree over the other, except at the truncated end. It is a white shell, trans- 
versely striated, or rather wrinkled, with a single tooth in one valve inserted into a corresponding cavity in the opposite valve. The specimens found in England are not more than a quarter of an inch from hinge to margin, and half an inch in breadth; but they have been found of double those dimensions, on some of the European shores.

Mr. Montagu found the $\boldsymbol{S}$. minutus burrowed in hard lime stone, at Plymouth, but it is very rare as a British species. It inhabits Norway and Greenland.

SCALE-LIKE RAZOR.

34. Solen squammosus. S. testa suborbiculari; cardinis dentibus duobus bifidis, ab umbone divergentibus. Linn. Trans. 8. p. 48.

Shell somewhat orbicular; hinge with two bifid teeth, diverging from the umbo.

Mont. Test. Brit. p. 565. Penn. Br. Zool.v. 4. p. 175.

A very thin, pellucid, white shell, extremely flat, of a somewhat circular shape, and in appearance like the scale of a fish. The outside is covered with minute punctures; the inside is smooth, white, and glossy. The teeth, which are two, are thin and erect.

Mr. Montagu, who has added this species to the list of British Testacea, has found a single valve only, on sand in Salcomb Bay, Devonshire. It was three eighths of an inch long, and half an inch broad. 
35. Solen Pinna. S. testa depresso-subovata; valvulisad cardinem rectis. Linn. Trans. 8. p. 48.

Shell somewhat oval, depressed ; valves, from the hinge, straight.

Mont. Test. Brit. p. 566. pl. 15. f. 3. Penn. Br. Zool. 1812. v. 4. p. 175.

This is a thin, brittle, pellucid, white shell, depressed and strongly wrinkled concentrically: one valve is rather concave, the other convex; both valves are connected by a cartilage, which runs in a straight line from the hinge to the extremity of the shell, giving it the appearance of an oval, divided in its longer diagonal. The inside is white, and has a blunt tooth in each valve, standing by the side of each other when the valves are closed, but not inserted; the largest tooth is in the concave valve.

Mr. Montagu, to whom conchology is so much indebted, has also discovered this shell, and given it the trivial name of Pinna, from the circumstance of the valves being connected, along one side of the shell, like the species of that genus. It is about the size of half the thumb nail, divided lengthwise. It was taken alive, by dredging, at Torcross in Devonshire.

In concluding the descriptive account of the species belonging to the genus Solen, it must be noticed that the S. crispus of Gmelin, p. 3228. No. 22, is the Pholas crispata, before described by him in its proper place, p.3215. No. 6, with a reference to Lister, which reference he has repeated in the genus Solen. 


\section{Genus 3. \\ TEL L INA. \\ GENERIC CHARACTER.}

Animal Tethys.

Testa bivalvis, anterius hinc ad alterum latus flexa.

Cardinis dentes (utplurimum) tres; laterales plani alterius testæ.

Animal a Tethys.

Shell bivalve, the anterior part curved to one side.

Hinge usually with three teeth; lateral teeth, in one of the valves, flat.

\section{GENERAL OBSERVATIONS.}

THE shells of this genus are, with one or two exceptions, of equal valves. That part of the Linnæan definition, which relates to the anterior part being curved to one side, must be taken with some limitation, since, in many species of the genus, this flexure is not visible; but the striæ, where this is wanting, are generally seen to diverge on the same part of the shell. Several of the species are deficient in lateral teeth.

There is so little apparent difference between some of the Tellens, and shells of other genera, especially those of Solen, and Venus, that it is sometimes difficult to decide to what particular genus they properly belong. This similitude was the cause of great confusion among both ancient and modern conchologists, till Linnæus affixed his scientific characters to the genus, and determined the species. Still, however, in the opinion of the French, there is room for improvement, since from the Linnæan 
Tellens they have formed three new genera, namely, Pandora, Capsa, and Lucina.

The animals inhabiting this genus differ but very little from those which occupy the shells of the genus Cardium and Venus. They are provided, before, with two simple and very long siphons, one of which (the largest) serves for the passage of the food, and the other for that of the excrements. They have, besides, a linguiform muscle, which projects from the hind part of the shell, and serves for a foot. These animals form the genus Peronca of Poli, who has given elaborate anatomical figures of them, in his splendid work on the Testacea of the Two Sicilies. What locomotion they possess is effected by opening and shutting the valves, at the same time lengthening and contracting their foot, by which means they accomplish their purpose, and move as far through the mud, or sand, as their limited powers of exertion will permit, or their wants require. 


\section{*. Shells oval and thickish.}

\section{TOOTHED TELLEN.}

1. Tellina gargadia. T. testa subrotunda, compressa, anterius rugosa, rima dentata. Linn. Syst. Nat. ed. 12. p. 1116. Linn. Gmel. p. 3228.

Shell roundish, compressed, and wrinkled on the fore part; valves toothed on the slope.

Petiv. Gaz. pl. 18. Rumph. Mus. t. 43. f. N. Favanne Catal. No. 1539. t. 6. Chem. Conch. 6. pl. 8. f. 63, 64. a. b.

A small, roundisk, white shell, with a slight flexure before; the anterior half transversely wrinkled; the fente is open, and the marginal slope thin, and set with about seven erect teeth; the inside is yellowish, and the middle tooth of the hinge cleft. Length an inch and a quarter; breadth rather more.

Inhabits the Indian Ocean, and is a rare shell.

\section{CATS-TONGUE TELLEN.}

Pl. 40. f. 2, 3. Mr. Strong.

2. Tellina Lingua-felis. T. testa subovata, scabra; squamulis lunatis quincuncialibus. Linn. Syst. Nat. ed. 12. p. 1116. Linn. Gmel. p. 3229.

Shell somewhat oval, rough; set with lunate scales disposed in a quincunx order.

Petiv. Gaz. t. 17. Rumph. Mus. t. 45. f. G. Gualt. Test. pl. 76. f. B. Knorr. Vergn. 2. pl. 2. f. 1. Favanne Conch. pl. 40. Chem. Conch. 6. pl. 8. f. 65. Encyclop. Method. pl. 289. f. 6. Martyn Univ. Conch. 4. pl. 138.

This is a very delicate species, rough, like shagrin, on the surface, and rayed, and striped with pink ; the scales are erect, and acute, and the fore part of the 
shell is sloping, and angular; the inside is white, and the middle tooth of the hinge is notched; lateral teeth, on both sides, acute, and inserted into the opposite margin. Length from one inch to two, breadth rather more.

Inhabits the Indian Ocean.

The figures of this shell by Knorr, and Martyn, are very beautifully drawn.

\section{STRIPED TELLEN.}

Pl. 35. f. 2, 3. Mrs. A. Schutz. Var. $\beta$. pl. 36. f. 2. Dr. Соомве.

3. Tellina virgata. T. testa ovali, striis transversis, recurvatis, anterius angulata; dentibus lateralibus, prominulis. Linn. Syst. Nat. ed. 12. p. 1116. Linn. Gmel. p. 3229.

Shell oval, with transverse recurved striæ, angular before; lateral teeth rather prominent.

Rumph. Mus. t. 45. f. G. Gualt. Test. pl. 86. f. G. Knorr Vergn. 2. t. 21 . f. 4. and 4. pl. 25. f. 1. Argenv. Conch. t. 22. f. G. Favanne Conch.t. 49. f. F. Chem. Conch. 6. pl. 8. f. 66-72. Encyclop. Method. pl. 288. f. 2, 3, 4 .

A flattish shell, concentrically striated, and marked with red rays on a yellow ground; the inside yellowish, and often rayed like the outside; the hinge has two teeth in one valve, and a cleft tooth in the other; remote teeth pointed. This shell is subject to vary considerably in colour; the variety $\beta$. pl. 36. f. 2 . is a striking instance, being rayed with rose colour on a white ground. The usual measure is about one inch and a half from apex to margin, and two and a half broad.

Inhabits the Indian and Atlantic Seas, and is not uncommon.

The figure in Gualtieri, pl. 89. f. E, referred to by VOL. I. 
Gmelin as a variety of this species, is too unlike the shell to be quoted.

\section{FRECKLED TELLEN.}

Pl. 36. $f .3$.

4. Tellina interrupta. T. testa oblonga, crassiuscula, antice angulata, rostrata, inflexa, dentibus lateralibus prominulis.

Shell oblong, thickish, angular before, beaked, and turned inwards; lateral teeth rather prominent.

List. Conch. t. 399. f. 238. Chem. Conch. 6. pl. 8. f. 73. Encyclop. Method.pl. 288. f. 7.

This shell, which is the T. interrupta of Dr. Solander, is strongly striated transversely, and covered, except at a few intervals, with interrupted lines of tawny, or brown, freckles. The beak is inflected, and wrinkled. The inside is glossy and yellow, with a white margin.

Inhabits the Indian and American Seas.

It is perfectly distinct from the $\boldsymbol{T}$. virgata, though considered as a variety of that shell by Chemnitz. It has not been noticed by Gmelin.

\section{ANGULAR TELLEN.}

\section{Pl. 43. f. 1. LinNaAn Societry's Cabinet.}

5. Tellina angulata. T. testa subovata, striis transversis, recurvatis, anterius angulata; dentibus lateralibus nullis. Linn. Syst. Nat. ed. 12. p. 1116. Linn. Gmel. p. 3329.

Shell somewhat oval, angular before, with transverse recurved striæ; no lateral teeth.

List. Conch. t. 406. f. 252. Chem. Conch. 6. 1. 9. f. 75. Encyclop. Method. pl. 290. f. 3. Schröt. Conch. 2. p.643. pl. 7. f. 8.

This species is distinguished by its abrupt slope on the hind part of the shell; it is of a white colour, rounded before, and faintly striated transversely ; the inside is 
white, and the lateral teeth are wanting. It inhabits the Indian Ocean, and is usually about an inch and a half long, and two inches broad.

The figure in Lister, pl. 388. f. 235., referred to by Gmelin, is not this shell; and figure 74, in pl. 9. of Chemnitz, may be considered as a variety of the $\boldsymbol{T}$. angulata, but not so characteristic of the species as f. 75.

\section{VARYING TELLEN.}

6. Tellina Gari. T. testa ovali, striis transversis recurvatis; dentibus lateralibus obsoletis. Linn. Syst. Nat. ed. 12. p. 111\%. Linn. Gmel. p. 3229.

Shell oval, with transverse recurved striæ; lateral teeth obsolete.

Rumph. Mus. pl. 45. f. D. Knorr Vergn. 6. t. 12. f. 2. Chem. Conch. 6. pl. 10. f. 92. Schröt. Conch. 2. p. 644. pl. 7. f. 9.

ß. Chem. Conch. 6. pl, 10. f. 94.

This species varies in its colours, like the $\boldsymbol{T}$. virgata, and somewhat resembles that shell in shape, but is of a smaller size, and narrower. It is a little inflected before, and has transverse wrinkles, crossed in the middle by perpendicular, or rather oblique, striæ. The pre- vailing colour is cinereous, with, or without, brown rays; sometimes it is white with blue rays, and sometimes bluish, spotted with white, and rayed with red; it occurs also of a reddish-white with red rays. The variety noticed by Chemnitz, pl. 10. f. 94. is a rough shell, with diverging striæ: his figure 93., is a Solen, see the Amethystine Razor.

This shell was first discovered by Rumphius; it inhabits the Indian Ocean. 


\section{BRITTLE TELLEN.}

7. Tellina fragilis. T. testa ovata, alba, gibba, striis transversis recurvatis; natibus flavescentibus. Linn. Syst. Nat. ed. 12. p. 1117. Linn. Gmel. p. 3230.

Shell oval, white, gibbous, with transverse recurved striæ; beaks yellowish.

Chem. Conch. 6. pl. 9. f. 84.

This is a white shell, with decussated striæ; the hinge has two teeth in one valve, and a single cleft tooth in the other; both valves are without lateral teeth. It is about three quarters of an inch long, and an inch broad.

Inhabits the European Ocean, and Caspian Sea.

This is a very different shell from the $\boldsymbol{T}$. fragilis, of Pennant, which shell is the Mya pratenuis, of Montagu.

\section{RUGGED TELLEN.}

\section{Pl. 41. $f$. 2, 3. Linnean Society's Cabinet.}

8. Tellina rugosa. T. testa ovata, rugis transversis undulatis; cardinis dentibus lateralibus duobus, primario in sinistra valva unico fisso, in altero duobus. Linn. Gmel. p. 3230.

Shell oval, with transverse waved wrinkles; hinge with two lateral teeth; left valve with a single cleft primary tooth, the other valve with two.

Born. Mus. Test. pl. 2. f. 3, 4. Chem. Conch. 6. pl. 8. f.62. Encyclop. Method.pl. 270. f. 1.

A whitish shell, with rugged, waved striæ, and angulated beak; the inside is white, and there are two teeth at the hinge in each valve; there is a cleft tooth in one 
valve, and strong lateral teeth in the other. The usual length about an inch and a half; breadth two inches. Inhabits the Indian and American Seas.

The specimen figured in pl. 41. is remarkahle for its waved striæ, which are not so conspicuously undulated in larger shells.

\section{INFLATED TELLEN.}

9. Tellina inflata. T. testa rotundata, crassa, tota nivea, gibba; stviis longitudinalibus subtilissimis. Linn. Gmel. p. 3230.

Shell rounded, thick, gibbous, and quite white; finely striated longitudinally.

Chem. Conch. 6. pl. 9. f. 76.

This shell is very slightly produced before, but not pleated. It has a bifid tooth in one valve, and remote lateral teeth; the longitudinal striæ are very fine, and best seen with a lens. It is described only by Chemnitz, and its country is not mentioned.

\section{PELLUCID TELLEN.}

10. Tellina crystallina. T. testa subtriangulari, alba, pellucida, antice inflexa, transversim costala.

Shell subtriangular, white, pellucid, transversely ribbed, and angular before.

Chem. Conch. 11. pl. 199. f. 1947, 1948.

This is a small, white shell, distinctly ribbed, and curved, or angular, on the fore part. It is described by Chemnitz, from a specimen in Spengler's Cabinet, and is about three quarters of an inch long, and an inch broad. 


\section{MULTANGULAR TELLEN.}

11. Tellen multangula. T. testa ovata, subventricosa, incequivalvi, decussatim striata, anterius sinuata; cardinis dente primario in sinistra valva solitario fisso, in altera duobus. Linn. Gmel. p. 3230.

Shell oval, of unequal valves, somewhat ventricose, with decussated striæ, and grooved before; hinge with a single primary cleft tooth in the left valve, and two in the other.

Chem. Conch. 6. pl. 9. f. 77.

This is a rough, inflated shell, of a whitish ash colour, thickly striated transversely, and crossed, with finer striæ, longitudinally; it is about an inch and three quarters long, and two inches and a half broad.

Inhabits the shores of Tranquebar.

\section{PAPER TELLEN.}

12. Tellina papyracea. T. testa tenui, ovata, ventricosa, transversim striata, anterius plicato-rugosa; cardinis dentibus lateralibus nullis, primariis duobus. Linn. Gmel. p. 3231.

Shell thin, oval, ventricose, and transversely striated, with pleated wrinkles on the fore part; hinge without lateral teeth, but with two primary teeth.

Chem. Conch. 6. pl. 9. f. 78. Encyclop. Method. pl. 290. f. 14.

A brittle, white shell, rounded at one end, and somewhat truncated and wrinkled at the other, with a considerable flexure in the middle; smooth and white within. Measures an inch in length, and an inch and a . half in breadth.

Inhabits the Coast of Guinea, but is very rare. 


\section{GIBBOUS TELLEN.}

13. Tellina gibbosa. T. testa subtrigona, ventricosa, subtiliter transversim striata; cardinis dente laterali valido. Linn. Gmel. p. 3231.

Shell somewhat triangular, ventricose, finely striated transversely; hinge with a strong lateral tooth.

Gualt. Test. pl. 77. f. Q.

A heart-shaped shell, of a whitish green colour, much inflated, and bending inwards on both sides; hinge with a single primary tooth. Length three quarters of an inch, breadth the same. Described only by Gualtieri.

\section{UNEQUAL-SIDED TELLEN.}

14. Tellina inæquilatera. T. testa aquivalvi, subrotunda, alba, striis versus marginem nonnullis transtersis. Linn. Gmel. p. 3231.

Shell of equal valves, roundish, white; with a few transverse striæ towards the margin.

Gualt. Test. pl. 88. f. $C$.

This is an obscure species, described by Gualtieri, but very indifferently defined.

\section{KNORR'S TELLEN.}

15. Tellina Knorrii. T. testa splendide rubra, margine violacea. Linn. Gmel.p. 3231.

Shell bright red, with a violet margin.

Knorr Verg $\boldsymbol{~}$. 5. pl. 21. f. 5.

This species, which has been named after its discoverer, is an inch and a quarter long, and two inches broad. Its country is not mentioned. 
MINUTE TELLEN.

16. Tellina pusilla. T. testa ovata, ventricosa, tenui, transverse slviata; cardine in altera valva edentulo, in altera dente primario duplici. Linn. Gmel. p. 3231.

Shell oval, ventricose, thin, transversely striated; hinge in one valve toothless, in the other a double primary tooth.

Schröt. Flussconch. pl. 4. f. 7. a. b.

A very small, brittle shell, of a dirty white colour. Inhabits the European rivers.

\section{OBLIQUE TELLEN.}

\section{Pl. 41. $f$. 4,5. Linnean Society's Cabinet.}

17. Tellina obliqua. T. testa ovali, glaberrima, lineis interruptis purpurascentibus insignita; dentibus lateralibus prominulis.

Shell oval, very smooth, and marked with interrupted purple lines; lateral teeth rather prominent.

This species is prettily marked with short, irregular purple lines, that appear on the inside, as well as without; the hinge has two teeth in one valve, and one in the other, besides the remote teeth; the margin is plain. It is an inch long, and an inch and a quarter broad.

It is arranged among the Tellens, in the Linnæan Society's collection of Shells, under the name of Obliqua : resembles the Venus Meroe, but has not a denticulated margin. 


\section{SPOTTED TELLEN.}

18. Tellina maculata. T. testa subovata, crassiuscula, decussatim striata, maculis irregularibus. Adams in Act. Soc. Linn. 3. p. 252. Item 8. p. 48.

Shell sub-oval, thickish, with decussated striæ, and irregular spots.

This species, which was found at Tenby, in South Wales, by the late Mr. Adams, has been admitted on his authority into the excellent descriptive catalogue of British Testacea, with which Dr. Maton, and Mr. Rackett, have enriched the eighth volume of the Linnæan Transactions.

RIVER TELLEN.

Pl. 47. f. 6.

19. Tellina amnica. T. testa oblique subovata, transversim sulcata. Maton in Act. Soc. Linn. 3. p. 44. pl. 13. f. 37, 38. ('T. rivalis), and 8. p. 60.

Shell obliquely sub-oval, transversely grooved.

Testa subcordiformi, transversim sulcata, umbone obtuso. Linn. Gmel. p. 3242. Mull. Zool. Dan. Prodr. $296 \%$.

Gualt. Test. pl. 7. f. C. C. Chem. Conch. 6. pl. 13. f. 134. Donov. Brit. Shells, t. 64. f. 2. Pult. in Hutch. Dorset. pl. 7. f. 2. a. Mont. Test. Brit. p. 86. Cardium amnicum.

A convex shell, somewhat heart-shaped, transversely grooved, and of a shining horn colour. The inside is bluish-white; the hinge is not in the middle of the shell; there are two teeth in one valve, and one in the other, besides the lateral teeth, which are strong and conspicuous. Length about a quarter of an inch, breadth three eighths of an inch.

Inhabits the Thames, and other European rivers. Was first distinguished as British by Dr. Maton, who found it in the River Avon. 
**⿻一丿火 Shells oval and compressed.

FOLIACEOUS TELLEN.

Pl. 36. $f$. 1. Dr. Соомве.

20. Tellina foliacea. T. testa ovali, pube scabra, rima serrata. Linn. Syst. Nat. ed. 12. p. 1117. Linn. Gmel. p. 3232.

Shell oval, angular compartment rough, fente serrated.

Rumph. Mus. t. 45. f. $\boldsymbol{K}$. Argenville Conch. pl. 22. f. E. Favanne

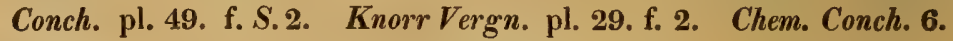
pl. 10. f. 95. Encyclop. Method.pl. 287. f. 4.

A very flat shell, of a fine orange colour, delicately, but distinctly, striated transversely. One end is rounded, the other truncated and angular, with rough longitudinal striæ; the upper edge, from the apex, is toothed. The hinge has a bifid tooth in one valve, and a plain tooth in the other; lateral teeth slight, and near the hinge. Length two inches, breadth rather more than three.

Inhabits the Indian Ocean, and was first described by Rumphius.

\section{WHITISH TELLEN.}

21. Tellina albida. T. testa ovali lavi; nymphis prominentibus. Linn. Mus. Lud. Ulr. 479. No. 23. Linn. Gmel. p. 3231.

Shell oval and smooth; nymphre prominent.

This species, according to Linnæus, is faintly striated transversely. It is the size of an egg, of a reddish white on the outside, and quite white within : the hinge has a distinct suture on each side, marked with minute transverse red striæ; in each valve there are three teeth.

Inhabits the European Ocean. 


\section{THIN TELLEN.}

Pl. 44. f. 3, 4.

22. Tellina tenuis. T. testa subtriangulari-planiuscula, tenerrima. Linn. Trans. 8. p. 52.

Shell very thin, flat, and subtriangular.

List. Conch.p1. 405. f. 251. Petiver Gaz. t. 94. f. 5. Da Cost. Brit. Conch. p. 210. Chem. Conch. pl. 12. f. 117. Pult. in Hutch. Dorset. p. 30. pl. 5. f. 3. Donov. Brit. Shells, pl. 19. f. 2. Mont. Test. Brit. p. 59. Linn. Trans. 8. p. 52. Penn. Brit. Zool. 1812.4. pl. 51. f. 2.

A very thin, brittle, depressed shell, finely striated -transversely, and somewhat angular before. It varies greatly in colour, being white, or red, or flesh-coloured, or yellow, or variegated with different colours, disposed in zones, over the surface of the shell; the hinge has a single bifid tooth in each valve. Length about half an inch, breadth three quarters.

Inhabits the European Seas, and is very common on many of the sandy shores of Great Britain.

This is a distinct species from the $\boldsymbol{T}$.planata, of Linnæus, with which it has sometimes been confounded. It was discovered by Lister, who has given a very good figure of the shell. 


\section{SEMI-STRIATED TELLEN.}

Pl. 45. f. 4 .

23. Tellina fabula. T. testa ovata, compressa, inflexa, anterius subrostrata; valva altera lavi, altera oblique substriata, striis reflexis. Linn. Gmel. p. 3239.

Shell oval, compressed, inflected, a little produced before; one valve smooth, the other with oblique reflected strix.

Gronov. Zooph. pl. 18. f. 9. Pult. in Hutch. Dorset. p. 30. pl. 12. f. 3. and f. 3. a. Donov. Brit. Shells, pl. 97. Mont. Test. Brit. p. 61. Linn. Trans. 8. p. 52.

A thin, white shell, not in shape unlike the $\boldsymbol{T}$. tenuis, but more produced before. It is distinguished immediately by its valves, one of which is quite plain, while the other is marked obliquely with almost imperceptible striæ. Specimens have occurred, though very rarely, striated on both sides. The hinge has three teeth in one valve, and two in the other. Length half an inch, breadth three quarters of an inch.

Inhabits the European and American Seas, and is found on some of the sandy shores of England and Wales. Many very fine specimens have been collected at Sandwich in Kent, where it was first discovered by the late Mr. Boys, mixed with $\boldsymbol{T}$. tenuis. 
FLAT TELLEN.

24. Tellina planata. T. testa ovata, compressa, transversin substriata, laevi; marginibus acutis. Linn. Syst. Nat. ed. 12. p. 1117. Linn. Gmel. p. 3232.

Shell oval, compressed, transversely substriated, smooth; margins acute.

Gualt. Test. pl. 89. f. G. Rugenf. Conch. pl. 3. f. 28. Born Test. pl. 2. f. 9.

A very flat shell, pellucid, and of a flesh colour; slightly curved, with very sharp margins.

This species has been confounded with the $\boldsymbol{T}$. tenuis; but it is evident, from his references, that Linnæus meant a different shell. Gmelin's T. complanata, p. 3239, is this shell.

\section{SHARP-EDGED TELLEN.}

\section{Pl. 44. f. 1.}

25. Tellina acuta. T. testa ovata, compressa, longitudinaliter subtilissime striata ; marginibus acutis.

Shell oval, compressed, very finely striated longitudinally; margins sharp.

This is a flat, thin, pellucid shell, of a white colour, with a tinge of yellow near the apex, but not perceptibly rayed. The surface is marked longitudinally with extremely fine striæ; the beak is slightly curved, and the angle is determined by a concavity running from the apex to the margin, in the upper shell; the margins are very sharp-edged. The hinge has two teeth in one valve, and one in the other; there is but one lateral tooth. 
The shell is two inches long, and three and a quarter broad.

Inhabits the West Indies.

This species greatly resembles the $\boldsymbol{T}$. planata. The figure in Gualtieri, to which Linnæus has referred, is very like our present subject, but it is broader in proportion to its length, and the margin is somewhat inflected.

\section{RAYED TELLEN.}

Pl. 38. f. 2, 3. Dr. СоомвE.

26. Tellina radiata. T. testa oblonga, longitudinaliter subtilissime substriata, nitida, sutura anali canaliculata. Linn. Syst. Nat. ed. 12. p. 1117. Linn. Gmel. p. 3232.

Shell oblong, very finely striated longitudinally, polished ; suture behind the beaks channelled.

List. Conch. t. 393. f. 240. Gualt. Test. pl. 89. f. 1. Argenville Conch. pl. 22. f. A. Knorr Delic. Nat. pl. B. 3. f. 8. - Vergn. 1. pl. 19. f. 1. and 4. pl. 2. f. 2. 4. Rugenf. Conch. 1. pl. 8. f. 22. Chem. Conch. 6. pl. 11. f. 102. Encyclop. Method. pl. 289. f. 2.

This is a highly polished, oblong shell, rayed with red on a white ground; it varies in colour, being sometimes without rays, and sometimes banded with yellow. The beak is slightly inflected, and the margin smooth, blunt, and somewhat incurved. The inside is white, or yellowish, and often stained near the margin, like the rays on the outside; the hinge has two teeth in one valve, and one in the other; the lateral teeth are remote. The size of the shell varies from one inch in breadth, to more than three. 
Inhabits the American Seas, and is not uncommon in the West Indies.

The shells quoted by Gmelin, as varieties, must be rejected, except Knorr's figure, which is our yellow variety, pl. 38. f. 3.

\section{RED TELLEN.}

Pl. 44. $f$. 2. Dr. Соомв Е.

27. Tellina sanguinea. T. testa ovato-oblonga, anterius angulata, subrostrata, transversim striata ; cardinis dentibus lateralibus acutis.

Shell oblong-oval, angular and somewhat beaked before, transversely striated; hinge with pointed lateral teeth.

A thin shell, of a red colour, strongly striated transversely, and crossed by almost imperceptible longitudinal striæ; it is of an oblong oval shape, very slightly inflected at the beak. The inside is reddish-white; the hinge has two teeth in one valve, and one in the other; the lateral teeth are sharp-pointed.

This shell is in the cabinet of Dr. Coombe. It is allied, in shape, to the $T$. lanceolata, of Chemnitz.

\section{BEAKED TELLEN.}

Pl. 37. f. 3. Dr. Соомв .

28. Tellina rostrata. T. testa oblonga, antice angulato-rostrata; angulis subdentatis. Linn. Syst. Nat. ed.12. p. 1118. Linn. Gmel. p. 3232.

Shell oblong, with an angular beak before; the angles slightly toothed.

List. Conch. pl. 382. f. 225. Petiver Amboin. pl. 17. f. 20. Rumph.

Mus. pl. 45. f. L. Gualt. Test. pl. 88. f. T. Argenville Conch. pl. 22. f. O. Favanne Conch. pl. 49. f. B. Knorr Vergn. 4. pl. 2. f. 3. 5.

Chem. Conch. 6. pl. 11. f. 105. Encyclop. Method.pl. 289. f. 1.

A thin, compressed, oblong shell, with a remarkably produced, angular beak ; the upper part is of a polished 
rose colour, near the margin it is of a dull green; the surface is striated transversely, and the margin is incurvated towards the beak; the inside is rose-coloured; the teeth, at the hinge, are bifid, and the lateral teeth are remote.

Inhabits the Indian Ocean.

The references of Gmelin to Lister, pl. 395. f. 242. to Gualtieri, Test. pl. 86. f. D. to Born Test. pl. 2. f. 12. and to Chemnitz, 6. pl. 10. f. 96. must be rejected, as not belonging to this species. Figure 104, however, of Chemnitz, may be admitted as a variety.

\section{SMOOTH TELLEN.}

Pl. 41. $f$. 1. Linn efan Society's Cabinet.

29. Tellina lævigata. T. testa ovata, lavigata, dentibus lateralibus marginatis, pube striato-scabra, nymphis inflexis. Linn. Syst. Nat. ed. 12.p. 1117. Linn. Gmel. p. 3232.

Shell oval, smooth; lateral teeth margined, angular division with rough strix; sutures inflected.

List. Conch. t. 387. f. 234. Chem. Conch. 6. pl. 12. f. 111 . Schröt. Conch. 2. p. 649. pl. \%. f. 10.

A thin, smooth, sub-oval shell, marked with almost imperceptible transverse and longitudinal strix; on the outside, white, or yellowish, with faint red rays : the inside pale red, flesh-coloured, or white; two primary teeth in each valve, the lateral teeth near the hinge. Length two inches, breadth two inches and a half.

Inhabits the European and Indian Seas.

Linnæus refers to Rumphius, pl. 45. f. 1. for the species, but his figure appears to be a variety of $T$. lingunfelis. Lister discovered the shell. 


\section{THREE-BANDED TELLEN.}

30. Tellina trifasciata. T. testa ovata, laviuscula, sanguineo-trivadiata, pube rugosa. Linn. Syst. Nat.ed. 12. p. 1118. Linn. Gmel. p. 3233. Shell oval, rather smooth, with three red rays, angular division rough. Chem. Conch. 6. pl. 12. f. 114. a. b.

A roundish, or rather subtriangular, shell, truncated at one end, finely striated transversely, and marked, distinctly, with three red rays, which are deeper, and narrower, at the apex, than the margin; the inside is white, and is also rayed, but not so strongly as without; the lateral teeth are strong. It is about three quarters of an inchlong, and rather more than an inch broad.

Is said to inhabit the European Ocean.

Is not figure 115 of Chemnitz, quoted by Gmelin as a variety of this shell, a distinct species?

Lister's figure, to which Linnæus has referred for this shell, is the $\boldsymbol{T}$. Ferröensis; and Donovan, in pl. 60. of his British Shells, has retained the same misnomer, for the last-mentioned species. The $\boldsymbol{T}$. trifasciata is not an English shell.

\section{DONAX TELLEN.}

\section{Pl. 45. f. 5. Linneran Society's Cabinet.}

31. Tellina donacina. T. testa ovata, compresso-planiuscula, laviuscula, anterius obtusissima. Linn. Syst. Nat.ed. 12. p.1118. Linn. Gmel. p. 3234.

Shell oval, rather flat, smoothish, and very blunt before.

Gualt. pl. 88. f. N. Pult. in Hutch. Dorset. p. 29. pl. 12. f. 3. b. Mont. Test. Brit. p. 58. Item Suppl. pl. 27. f. 3. Linn. Trans. 8. p. b0. pl. 1. f. 7 .

This is an oval shell, semipellucid, and of a yellowish white colour, marked with many red rays, diverging

VOL. I. 
from the apex to the margin. It is shaped like a Donax, and is very minutely striated transversely: the hinge is placed towards one end, and has two teeth (one of which is bifid) in one valve, and a single tooth in the other. It is about half an inch long, and an inch broad.

This species, which was first noticed by Gualtieri, inhabits the Mediterranean. It is also a British shell, and was found on Sandwich Flats, by Mr. Boys. Dr. Pulteney has since met with it at Weymouth, and Mr. Montagu on the Cornish and Devonshire Coasts. Is not this shell figured by Lister in pl. 385?

\section{TRUNCATED TELLEN.}

32. Tellina truncata. T. testa ovali, compressn, substriata; parte antica truncata, suturaque distincta. Linn. Gmel. p. 3234.

Shell oval, compressed, somewhat striated, truncated before.

This species is admitted on the authority of Gmelin, but from his own confession of the resemblance it bears to the $\boldsymbol{T}$. incarnata, of Linnæus, there is reason to believe that it may prove a variety only of that shell.

It inhabits Java.

\section{TRIANGULAR TELLEN.}

33. Tellina trilatera. T. testa plana, anterius truncata, flava, vertice albo; cardinis dente primario et laterali solitariis. Linn. Gmel. p. 3234 .

Shell flat, yellow, and truncated before; umbo white; hinge with a single primary and lateral tooth.

Chem. Conch. 6. pl. 10. f. 85.

A yellowish shell, concentrically striated, except about the apex, which is very smooth, and white; the 
fore part is obtuse, and, towards the inferior margin, slightly corrugated. Length an inch and three quarters, breadth two inches and a quarter.

Described and figured by Chemnitz, from a specimen in Spengler's Museum.

\section{OBLONG TELLEN.}

34. Tellina oblonga. T. testa oblonga, fragili, flavicante; cardinis dente primario, in altera valva, solitario, in altera duplici. Linn. Gmel. p. 3234.

Shell oblong, brittle, yellowish; hinge with two primary teeth in one valve, and one in the other.

Chem. Conch. 6. pl. 10. f. 87.

A very thin, egg-shaped shell, somewhat inflected at one end; the hinge not placed in the middle; the margins plain. Length about three quarters of an inch, breadth rather more than an inch.

Inhabits the European Ocean. Described only by Chemnitz.

\section{SPENGLER'S TELLEN.}

\section{Pl. 3\%. f. 2. Dr. Соомве.}

35. Tellina Spengleri. T. testa alba, transversim striata, utrinque bifariam uncinata; valva altera extrorsum, altera introrsum arcuatum flexa. Linn. Gmel. p. 3234.

Shell white, transversely striated, with a row of spines running towards each end in both shells; one valve bending outwards, the other inwards.

Lister Conch. pl. 398. f. 237. Spengler Besch. Berl. Naturf. 1. p. 38\% pl. 9. f. 1. 3. Chem. Conch. 6. pl. 10. f. 88-90. Encyclop. Method.pl. 287.f. 5. a.b.

A long, narrow, white shell, with a rosy tip, strongly striated transversely, and ridged with teeth, or spines, 
running from the hinge to each end; beak angular, inflected, and waved; margins plain and blunt. Inside white, with a stain of yellow under the hinge; two primary teeth in one valve, and one in the other, lateral teeth remote. Length three quarters of an inch, breadth two inches and a half.

Inhabits the shores of the Nicobar Islands, and is found in different parts of the Indian Ocean.

This shell was first figured by Lister, from a worn specimen, without the spines. Chemnitz in fig. 88. has represented the shell with great fidelity.

\section{CARNATION TELLEN.}

Pl. 45. f. 1.

36. Tellina Ferröensis. T. testa oblongo-ovata, compressa, albo rubelloque radiata, subtiliter transversim striata; cardinis dentibus lateralibus nullis. Linn. Gmel. p. 3235.

Shell oblong-oval, compressed, rayed with white and reddish, finely striated transversely; hinge without lateral teeth.

Lister Anim. Angl. App. t. 1. f. 8. Conch. t. 394. f. 241. Petiv. Gaz. t. 94. f. 9. Penn. Brit. Zool. 1812. 4. pl. 50. f. 3. Dn Costa Brit. Conch. p. 209. t. 14. f. 1. (T. radiata) Born Test. pl. 2. f. 5. (T. angulata) Chem. Conch. 6. pl. 10. f. 91. Donov. Brit. Shells, pl.60. (T. trifasciata) Mcnt. Test. Brit. p. 55. Linn. Trans. 8. p. 49.

An oblong shell, truncated at one end, and rounded at the other ; the surface finely striated transversely, and marked with red and white rays; striæ waved over the ridge which rums from the apex to the angular margin; inside white, or rose-coloured; hinge with two teeth in each valve; lateral teeth wanting. Length from half an inch to an inch, breadth from one inch to two. 
Inhabits the Northern Ocean, and is found, though rather sparingly, on the shores of Great Britain. Single valves occur at Sandwich; at Tenby it is not uncommon; it has been found at Poole and Weymouth in Dorsetshire, at Scarborough in Yorkshire, and on several parts of the Coast of South Devonshire. Lister discovered the species.

\section{BLUSHING TELLEN.}

\section{Pl. 42. f. 1. Mrs, Mawe.}

37. Tellina operculata. T. testa inaquivalvi, oblonga, rosea, subtiliter decussatim striata; valva altera convexa, altera fere plana. Linn. Gmel. p. 3235.

Shell of unequal valves, oblong, and rose-coloured, finely decussated; one valve convex, the other almost flat.

Chem. Conch. 6. pl. 11.f. 97. Knorr Vergn. 6. pl. 12. f. 1.

A pale rose-coloured shell, covered, when recent, with a green epidermis, a portion of which often adheres to the margin; the surface is very finely striated, both transversely and longitudinally ; the beak is produced and angular, the valves are dissimilar, one being convex, the other nearly flat, and somewhat smaller; the margins are flexuous and acute. The inside is rosy, and the hinge has two teeth (one of which is notched) in one valve, and one in the other; there are no lateral teeth. Length about an inch and a half, breadth three inches.

Inhabits the Indian Ocean, but is a rare shell. 
WHITE TELLEN.

38. Tellina alba. T. testa ovali, incquivalvi, decussatim striata, antice inflexa et angulata; cardinis dente primario bifidn.

Shell oval, with unequal valves, decussated, inflected and angular before; primary tooth of the hinge bifid.

Chem. Conch. 6. pl. 11. f. 98. Linn. Gmel. p. 3235. No. 32. Var. $\beta$.

This shell is given by Gmelin as a variety only of $\boldsymbol{T}$. operculata, but it is clearly a distinct species, of a different shape and colour. The $\boldsymbol{T}$. alba, has a very slight tinge of yellow; the striæ on the surface are strong, and the slope, from the hinge to the beak, is rather concave, than convex. The hinge has two teeth in one valve, and one in the other; the lateral teeth are obsolete. Length an inch and three quarters, breadth two inches and three quarters.

First described and figured by Chemnitz.

\section{GLASSY TELLEN.}

39. Tellina Hyalina. T. testa ovali oblonga, inaquivalvi, plana, pellucida, glabra, subtilissime decussatim striata, margine acutissimo, cardinis dentibus lateralibus nullis. Linn. Gmel. 1). 3235.

Shell oblong oval, with unequal valves, flat, pellucid, and smooth, with very delicate decussated strix, margin very sharp, hinge without lateral teeth.

Chem. Conch.6. pl. 11. f. 99.

A very brittle, pellucid shell, perfectly white, with the hinge placed towards one end; there are two teeth in one valve, and one in the other. Length an inch and a quarter, breadth two inches and a quarter. Inhabits the Indian Ocean. Gmelin refers to Schröter, Einl. in Conch. 3. p. 6. No. 14, for a variety of this shell. 


\section{IANCE-SHAPED TELLEN.}

Pl. 43. f. 2. Dr. Соомв E.

40. Tellina lanceolata. T. testa ovali, tenuissima, pellucida, albida, transversim striata, anterius acuminata; cardinis dentibus lateralibus in altera valva nullis. Linn. Gmel. p. 3236.

Shell oval, very thin, pellucid, transversely striated, and sharp pointed before; hinge without lateral teeth in one valve.

Chem. Conch. 6. pl. 11.f. 103.

A white shell, sometimes reddish, rounded at one end, and lancet-shaped at the other; slightly inflected at the beak. Length three quarters of an inch, breadth an inch and a quarter.

Inhabits India, but is very rare. Described only by Chemnitz.

\section{OPALINE TELLEN.}

41. Tellina opalina. T. testa ovali, pellucida, lucis reflexione et refractione variante, costa in utraque valva alba a cardine ad marginem exteriorem procedente. Linn. Gmel.p. 3236.

Shell oval, pellucid, varying in different positions of light; a white rib in each valve, proceeding from the hinge to the outer margin.

Chem. Conch. 6. pl. 12 . f. 107.

A thin, white, diaphanous species, finely striated transversely, and reflecting from its surface, different colours, like the interior of pearlaceous shells. A white rib running from apex to margin, occasions the fore part of the shell to be angular, but not inflected; hinge with two teeth in one valve, and one in the other. Length an inch, breadth an inch and a half.

Inhabits the Indian Ocean. 
Chemnitz described this shell from a specimen in Spengler's Cabinet, and Gmelin has quoted Schröter for a variety, under the title of Tellina papyracea alba Spengleri.

\section{SCARLET TELLEN.}

42. Tellina coccinea. T. testa ovali, pellucida, coccinea, subtiliter transversim striata. Linn. Gmel. p. 3236.

Shell oval, pellucid, scarlet, finely striated transversely.

Chem. Conch. 6. pl. 12. f. 109.

In this species there is a calosity near the hinge, like what we meet with among the Solens; the inside is scarlet and white. Length seven eighths of an inch, breadth an inch and a quarter.

Inhabits the Mediterranean.

\section{CHALKY TELLEN.}

43. Tellina calcarea. T. testa ovali, tenui, alba; cardinis dente primario in altera valva fisso, alterius fovec inserto. Linn. Gmel. p. 3236.

Shell oval, thin, white; hinge with the primary tooth, in one valve, cleft ; in the other, inserted into a cavity.

Chem. Conch. 6. pl. 13. f. 136.

An oval shell, smooth, and very fragile, marked with fine transverse striæ, angular and inflected before, plain and rounded behind. Length three quarters of an inch, bread th rather more than an inch.

Inhabits the sea round Ireland. 


\section{LISTER'S TELLFN.}

44. Tellina pectinata. T. testa rotundata, plana, tenui, subfusca, longitudinaliter striata. Linn. Gmel.p. 3236.

Shell rounded, flat, thin, brownish, longitudinally striated.

List. Conch. pl. 300, f. $13 \%$.

This is an obscure species, figured only by Lister, who described it as of a yellowish colour, and channelled on each side from the beak. Length two inches and a quarter, breadth two inches and a half.

Among Lister's notes, it is mentioned as an East Indian shell.

\section{NARROW TELLEN.}

45. Tellina angusta. T. testa planiuscula, rubra, albo-radiata, altero fine acuminata, altero rotundata. Linn. Gmel. p. 3236.

Shell flattish, red with white rays, one end pointed, the other rounded.

List. Conch. pl. 383. f. 226.

A narrow shell, rather less than half an inch long, and an inch broad.

MADAGASCAR TELLEN.

Pl. 39.f. 2, 3. Mr. JENNINGS.

46. Tellina Madagascariensis. T. testa ovali, altero fine subacuminata. Linn. Gmel. p. 3237.

Shell oval, somewhat pointed at one end.

List. Conch. pl. 386. f. 233.

A thick, heavy, compressed shell, of a flesh colour, with a rosy tip and margin. One end is rounded, the 
other produced, and inflected; a ridge in one valve, runs from the apex to the anterior margin; in the other valve a sulcus; fine longitudinal striæ cover the surface of the shell; the margins very obtuse. The inside is a fine rose colour; the muscular depressions very strong; the hinge has a single primary tooth in each valve, one of which is notched: there is a small approximate lateral tooth in one valve, but none in the other. Length two inches and a quarter, breadth three inches and three quarters.

Inhabits Madagascar.

We are indebted for the knowledge of this species, to Dr. Lister, who has given a good figure of the shell, with the following note. "This large Tellen is of a cornelian colour, very smooth, and very thick and ponderous, in those of this growth and bigness, but the lesser are thin and light, and prettily fasciated, at least some of them." It is a rare shell.

\section{FLAT STRIATED TELLEN.}

Pl. 39. f. 1. Dr. Соомв Е.

47. Tellina punicea. T. testa ovali, plana, aquilatera, punicea, densissime transversin striata. Linn. Gmel. p. 3239.

Shell oval, flat, with equal sides, thickly striated transversely, and of a light red colour.

Born Test. pl. 2. f. 8. Pult. in Hutch. Dorset. pl. 7. f. 5. Donov. Brit. Shells, pl. 123. Mont. Test. Brit. p. 57. Linn. Trans. 8. p. 51. Penn. Brit. Zool. 1812. 4. p. 179.

A flat shell, densely striated transversely, and very delicately crossed longitudinally, of a light red colour, with whitish bands, and a tinge of yellow at the tip; in small specimens the red is much deeper, and the longitu- 
dinal striæ invisible; one end of the shell is rounded, the other somewhat angular and inflected. The inside is very smooth and stained, more or less, of a rose colour; the primary teeth of the hinge bifid, the remote teeth prominent. Length an inch and a quarter, breadth two inches and a quarter.

Dr. Pulteney first described this as a British shell. It has been found between Weymouth and Portland in Dorsetshire, by Mr. Bryer. It is called T. lata by Dr. Pulteney, and T. incequistriata, by Mr. Donovan.

\section{DEPRESSED TELLEN.}

\section{Pl. 45. f. 3. Mr. Sowerby.}

48. Tellina depressa. T. testa incequilatera, depressa, minutissime striata. Linn. Gmel. p. 3238.

Shell with unequal sides, depressed, and very minutely striated.

Gualt. Test. pl. 88. f. L. Chem. Conch. 6. pl. 10. f. 96. Pult. in Hutch. Dorset. pl. 5. f. 2. Donov. Brit. Shells, pl. 163. Mont. Test. Brit. p. 56. Linn. Trans. 8. p. 51. Penn. Brit. Zool. 1812. 4. p. 179.

A thin, flat, oval shell, of a light orange, or yellow colour ; one end rounded, the other produced, angular, and rather inflected; finely striated transversely; umbones acute, margin very sharp. Inside light orange, hinge with two teeth in one valve, and three in the other; one tooth remote. Length an inch, breadth an inch and a half. Foreign specimens larger, and red coloured.

Inhabits the European seas, and is the T. squalida of Dr. Solander. It was first noticed as British by Dr. Pulteney, who described it under the name of $\boldsymbol{T}$. squa- 
lida, from a few specimens found near Poole, and at Weymouth, in Dorsetshire. Mr. Donovan found it, in plenty, upon the sands on the south-east side of Tenby, Pembrokeshire ; and Mr. Montagu, in Cornwall and Devonshire.

\section{PURPLE TELLEN.}

49. Tellina purpurascens. T. testa utrinque purpurascente. Linn. Gmel. p. $323 \%$.

Shell entirely purple.

List. Conch. pl. 391. f. 230.

This shell, which is figured by Lister, is an inch and a half long, and two inches broad. Gmelin refers to Gualtieri, pl. 77. f. L. and M. for varieties of this species, but they are evidently distinct.

\section{ROUGH TELLEN.}

50. Tellina aspera. T. testa altero fine acuminata, intus lutescente, exterius radiata, et striis transversis aspera. Linn. Gmel.

Shell pointed at one end, radiated, and roughly striated transversely; yellowish within.

This shell is described only by Gmelin, who says that it is an inch and three quarters long, and three inches broad. Its country is not mentioned. 


\section{SUBCUNEATED TELLEN.}

51. Tellina triangularis. T. testa subcuneata, albida, transverse striata. Linn. Gmel. p. $323 \%$.

Shell somewhat wedge-shaped, whitish, transversely striated.

List. Conch. p. 401. f. 244.

This is a thin species, described by Lister, who has added a variety, f. 245. of the same plate, which, from its shape, has more the appearance of a distinct species.

\section{BROAD TELLEN.}

52. Tellina lata. T. testa alba incequilatera, altero fine subacuminata. Linn. Gmel. p. 3237.

Shell white with unequal sides, a little pointed at one end.

List. Conch. pl. 407. f. 253.

This species is something like the $\boldsymbol{T}$. depressa; it is an inch and a quarter long, and two inches and three quarters broad.

Inhabits the Norwegian Ocean.

\section{JAMAICA TELLEN.}

53. Tellina Jamaicensis. T. testa crassa, rostro extus purpurascente. Linn. Gmel.p. $323 \%$. Shell thick, beak purplish on the outside.

List. Conch. pl. 408. f. 254.

An oval shell, rounded at one end, and rather produced at the other, with an incurvated margin. Figured only by Lister.

Inhabits Jamaica. 
WHITISH TELLEN.

54. Tellina albicans. T. testa albida, fascia candida ; intus flava. Linn. Gmel. p. 3238.

Shell whitish, banded; within yellow.

Gualt.pl. 77. f. $\boldsymbol{H}$.

Gualtieri has figured this species, but has not mentioned its country.

\section{REDDISH TELLEN.}

55. Tellina rufescens. T. testa rufescente luteo maculata, decussatim striata. Linn. Gmel. p. 3238.

Shell reddish spotted with yellow, with decussated striæ.

Gualt. Test. pl.85. f. C.

This shell, which is figured only by Gualtieri, is three quarters of an inch long, and an inch and a quarter broad.

\section{BANDED TELLEN.}

56. Tellina fasciata. T. testa inaquilatera, subtilissime transversim striata, candido et subalbido alternatim fasciata. Linn. Gmel. p. 3238.

Shell with unequal sides, finely striated transversely, alternately banded with bright and dull white.

Gualt. Test. pl. 89. f. B.

One end of this shell is somewhat pointer. It is about an inch long, and an inch and a half broad. Its country is not mentioned. 
57. Tellina striata. T. testa incequilatera, utrinque rotundata, ex roseoalba, pellucida. Linn. Gmel. p. 3238.

Shell with unequal sides, rounded at both ends, rosy white, pellucid.

Gualt. Test. pl. 89. f. C. Mont. Test. Brit. p. 60.

A smooth shell, minutely striated concentrically, of a rosy white on the outside, and within. There are two teeth at the hinge, and a strong remote lateral tooth on each side, in both valves. Length an inch and a quarter, breadth two inches.

Inhabits the European Ocean, and has been found in England by Mr. Bryer, between Weymouth and Portland, in Dorsetshire. The reference to Chemnitz, adopted by Mr. Montagu, has not been noticed, from a firm persuasion that the shell quoted in his Conchology, vol. 6. pl. 12. f. 117. is a representation of the $\boldsymbol{T}$. tenuis.

\section{ROSY TELLEN.}

58. Tellina rosea. T. testa costis, tenuibus a cardine ad marginem decurrentibus. Linn. Gmel. p. 3238.

Shell rosy, with thin ribs running from the hinge to the margin.

KnorrVergn. 5. pl. 9. f. 3.

This shell, which is described by Knorr, is an inch long, and an inch and a half broad. Its country is unknown. 
ADANSON'S TELLEN.

59. Tellina Adansoni. T. testa albida, cardine violaceo. Linn. Gmel. p. 3239.

Adans. Seneg. pl. 17. f. 9. Poron.

This shell was discovered by Adanson on the African shore, where it occurs abundantly, in the sinuosities of the rocks, filled with sand. It is a very small species, not being more than the eighth of an inch long.

\section{RETICULATED TELLEN.}

60. Tellina cancellata. T. testa tenui, sordide alba, sulcis numerosis tenuissimis longitudinalibus rugas transversas decussantibus. Linn. Gmel.p. 3239.

Shell thin, dirty white, with numerous fine longitudinal grooves, crossing the transverse wrinkles.

Adams. Seneg. pl.17. f. 12 . Pirel.

This shell, described by Adanson, is very thin and brittle, but not transparent. It is externally marked with about a hundred extremely fine grooves, which are crossed by many ridges, giving the shell the appearance of fine net-work. It is an inch broad, and rather less in length.

Inhabits the sandy shores of the island of Goree.

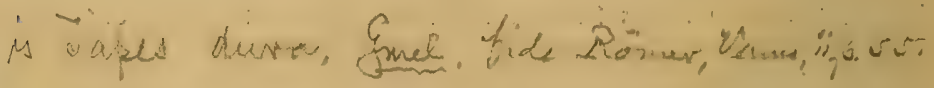




\section{FASICATED TELLEN.}

61. Tellina strigosa. T. testa albicante fasciata, glabra, ad marginem rugosa; cardinis dentibus in valva dextra duobus, in sinistra tribus. Linn. Gmel.p. 3239.

Shell with whitish bands, smooth, and wrinkled at the margin; hinge with two teeth in one valve, and three in the other.

Adans. Seneg. pl. 17. f. 9.

This shell, externally, bears some resemblance to the T. Madagascariensis, but differs essentially in the teeth. It is rounded behind, and rather produced and plaited before. The colour of the bands which cross the shell, in young specimens, is yellow; in old ones, grey-violet. Length about an inch and a half; breadth two inches and a half, but subject to considerable variation in size.

Inhabits the sandy shores of Macao, one of the Molucca islands.

\section{SNOWY TELLEN.}

Pl. 46. $f$. 1. Mrs. MaWE.

62. Tellina nivea. T.testa ovata, compressa, anterius subangulata, cardinis dente primario in altera valva solitario, fisso, duplici alterius inserto.

Shell oval, compressed, somewhat angular before; hinge with a solitary, cleft, primary tooth, in one valve, inserted between two others in the opposite valve.

This is a smooth, delicate shell, perfectly white, and of an oval shape, rounded at one end, and rather produced, and angular, at the other; besides the primary teeth, mentioned in the specification, there is one rather remote. Length an inch and an eighth; breadth an inch and five eighths.

Inhabits the American Ocean.

VOL. I. 


\section{SULCATED TELLEN.}

Pl. 47. $f$. 1. Mrs. MaW E.

63. Tellina sulcata. T. testa subovali, plana, transtersim sulcata, anterius angulato-inflexa; cardinis dentibus primariis duobus bifidis, lateralibus prominulis.

Shell somewhat oval, flat, transversely sulcated, angular and inflected before; primary teeth two, cleft; lateral teeth prominent.

A flat, straw-coloured shell, transversely grooved, rounded behind, and produced before into an angular, inflected, undulated beak; margins plain. Inside strawcoloured, the same as without; hinge with two cleft teeth in one valve, and one in the other. Length rather less than an inch; breadth about an inch and threeeighths.

This shell resembles the $\boldsymbol{T}$. crystallina of Chemnitz, Conch. 11. pl. 199. f. 1947, 1948, but differs in the colour, and shape of the beak. Its country is unknown.

\section{ANGULAR TELLEN.}

64. Tellina angulosa. T. testa ovali, planiuscula, transversim striata, antrorsum inflexo-angulata; cardinis dente primario bifido; lateralibus remotis. Linn. Gmel.p. 3244.

Shell oval, flattish, transversely striated, the fore part angularly inflected; hinge with a cleft primary tooth; lateral teeth remote.

Chem. Conch. 10. pl, 170. f, 1654, 1655.

This shell inhabits America, and is about an inch long, and two inches broad. It resembles the preceding species in some particulars, but is a different shell. 


\section{LASKEY'S TELLEN.}

65. Tellina Laskeyi. T. testa ovato-oblonga, lavi ; valvula alterius dente primario solitario, alterius duobus approximatis subbifidis, dentibus lateralibus nullis.

Shell oblong-oval, smooth; in one valve a solitary primary tooth, in the other two approximate teeth, a little cleft; lateral teeth wanting.

Mont. Test. Brit. Suppl. p. 28. pl. 28. f. 3. Penn. Brit. Zool. 1812. 4. p. 178.

A purplish-white shell, covered, when recent, with an olive-yellow epidermis; one end rounded, the other obtusely pointed, like the Donax Trunculus. The inside is clouded with purple, and the margin is channelled, from the teeth almost to the end of the longest side. Length half an inch; breadth three quarters.

Inhabits the Frith of Forth, in Scotland. Discovered by $\mathrm{Mr}$. Laskey, and described and figured by $\mathrm{Mr}$. Montagu. 
66. Tellina balaustina. T. testa dilatato-orbiculata, laviuscula; vailvula altera dentibus lateralibus. Linn. Syst. Nat. ed. 1812. p. 1119. Linn. Gmel. p. 3239.

Shell dilated-orbicular, smoothish, with lateral teeth in one valve.

A whitish shell, nearly round, but rather broader than long, marked with obsolete red rays. It is the size of a lupine seed.

Inhabits the Miditerranean.

We are not acquainted with this shell, which Linnæus compares to the flower of the pomegranate.

\section{RASP TELLEN.}

Pl. 35.f. 1. Mr. JENNINGS.

67. Tellina scobinata. T. testa lenticulari, scabra, squamis lunatis, quincuncialibus. Linn. Syst. Nat. ed. 12. p. 1119. Linn. Gmel. p. 3240.

Shell lenticular, rough, with lunate scales disposed in a quincunx order. List. Conch. pl. 302. f. 143. Rumph. Mus. pl. 43. f. E. Petiver Amboin. pl. 18. f. 7. Gualt. Test. pl. 76. f. E. Knorr Vergn. 6. pl. 37. f. 3. Chem. Conch. 6. pl. 13. f. 122-124. Encyclop. Method. pl. 291. f. 4. $a-d$.

A white, or fiesh-coloured shell, with a pale yellow apex; angular and slightly inflected on the fore part, and every where covered, except at the apex, with rough scales, resembling a baker's rasp. Inside pale yellow; hinge with two primary teeth in one valve, 
and one in the other; lateral teeth strong and prominent. Length two inches; breadth two and a quarter.

Inhabits the Indian Ocean.

This shell was first described by Lister, who has represented the species much better than either Rumphius, or Petiver.

\section{SMOOTH TELLEN.}

Pl. 37. $f$. 1. Mr. Jennings.

68. Tellina lævis. T. testa suborbiculata, compressa, albida; cardinis dente primario fisso.

Shell somewhat orbicular, compressed, and whitish; primary tooth of the hinge cleft.

List. Conch. pl. 266. f. 102. Born Test. pl. 2. f. 11. Chem. Conch. 6. pl. 12. f. 112.

This shell has been considered the same as the following species, or $\boldsymbol{T}$. Remies of Linnæus, though they differ very essentially. The $\boldsymbol{T}$. lavis is rounded at one end, and somewhat angular, and inflected, at the other ; the surface is smooth, or very finely, and almost imperceptibly striated transversely. The shell is white both within and without, but sometimes tinged with straw colour, disposed in bands on the outside, and uniform within. The hinge has two teeth in one valve, and one in the other; lateral teeth strong, one near the hinge, the other remote. Length of large specimens two inches and a half; breadth three inches and a quarter. Inhabits the West Indies, and was first noticed by Lister. 
WAVED TELLEN.

Pl. 38.f. 1. Mr. Jennings.

69. Tellina Remies. T. testa suborbiculata, compressa, rugosa. Linn.

Syst. Nat. ed.12. p. 1119. Linn. Gmel. p. 3239. Shell somewhat orbicular, compressed, and wrinkled. Rumph. Mus. pl. 42. f. I. Chem. Conch. 6. pl. 12. f. 113.

This shell is regularly marked with transverse, waved ridges; it is strong, nearly orbicular, and uniformly white, unless accidentally stained; the fore part is slightly angular and inflected; the hinge the same as in the preceding species. Length about two inches and a half; breadth rather more.

Inhabits the Indian and American Ocean. The American specimens are said to be sometimes yellowish, and less wrinkled.

Linnæus has referred, by mistake, to pl. 43 of Rumphius, instead of 42 , and Gmelin has repeated the error.

\section{LATTICE TELLEN.}

Pl. 42. f. 2, 3.

70. Tellina reticulata. T. testa lentiformi, compressa, reticulata. Linn. Syst. Nat.ed. 12.p. 1119. Linn. Gmel.p. 3240. Shell of a lens-shaped, compressed, and reticulated.

Rumph. Mus. pl. 43. f. E. Chem. Conch.6. pl. 12. f. 118. Encyclop. Method. pl. 292. f. 2. Pult. in Hutch. Dorset. pl. 5. f. 4. Mont. Test. Brit. p. 66. Linn. Trans. 8. p. 54. pl. 1. f. 9. Penn. Brit. Zool. 1812. 4. p. 181.

A suborbicular and rather compressed shell, of a whitish colour; the surface marked with transverse ridges, and crossed, in the interstices, with numerous 
minute longitudinal striæ, which require a lens to detect them; the inside is yellow; the hinge has two small primary teeth, with a deep, linear hollow, terminating at the base of one of the prominent lateral teeth. Length an inch and a quarter; breadth rather more.

Inhabits the Indian Ocean, and has also been found, though rarely, in England. Dr. Pulteney, who first described it as British, under the name of $\boldsymbol{T}$. proficua, met with it on the north shore at Poole, and at Weymouth, in Dorsetshire.

\author{
THREAD-GIRDLED TELLEN.
}

Pl. 42. f. 4, 5. Mr. Sower BY.

71. Tellina Radula. T. testa lentiformi, convexa, transversim striata ; margine anteriore juxta cardinem rectiuscula. Act. Soc. Linn. 8. p. 54.

Shell of a lens-shaped, convex, transversely striated; anterior margin near the hinge, alinost straight.

Petiver Gaz. pl. 93. f. 18. Favanne Conch. pl. 48. f. 3. Donov. Brit. Shells, pl. 130. Mont. Test. Brit. p. 68. pl. 2. f. 1, 2. Penn. Brit. Zool. 1812. 4. p. 181.

A white shell, with a brown epidermis, nearly orbicular, and covered with close set, rough, concentric striæ; there is a small, oblong, heart-shaped depression on the anterior margin, close to the beak; and a slight furrow running from the posterior part of the apex, in each valve, and meeting at the margin, where it is a little inflected. Inside chalky-white; margin whiter than the rest, and slightly puckered; hinge with two small primary teeth in each valve; no lateral teeth. 
Length about an inch and a quarter; breadth rather more.

Inhabits the European seas, and has been found abundantly, by Mr. Montagu, on the coast of Cornwall, particularly at Falmouth; it is also to be met with on parts of the coast of South Devon, and in Carmarthenshire, about Laugharne.

This shell was first figured by Petiver, under the name of "Thread-girdled White Cockle." It is the Venus borealis of Donovan.

\section{ROUGH TELLEN.}

72. Tellina scabra. T. testa subquadrata, alba, tumida, antice inflexa, transversim striata, rugosa; cardinis dente primario unico.

Shell squarish, white, tumid, inflected before, and transversely striated; hinge with a single primary tooth.

Chem. Conch. 11. pl. 199. f. 1943, 1944.

This species resembles the $T$. Radula in having a rough, transversely striated exterior, and a similar furrow behind; but it differs in having but one primary tooth, and in being provided with two strong lateral teeth. It is smooth, and white, within. Length about an inch and a half; breadth the same. 


\section{PRICKLY TELLEN.}

73. Tellina muricata. T. testa suborbiculata, compressa, alba, longitudinaliter dense striata, striis imbricatis, cardinis dentibus primariis duobus.

Shell suborbicular, compressed, closely striated longitudinally, striæ imbricated; hinge with two primary teeth.

Chem. Conch. 11. pl. 199. f. 1945, 1946.

A roundish shell, covered with imbricated, rough striæ, and strongly serrated from the apex, to the posterior margin. Inside white, and striated; hinge with two primary teeth, and two strong lateral ones, inserted into opposite cavities.

\section{OBSOLETE TELLEN.}

74. Tellina fausta. T. testa suborbiculata, striis transversis minutissimis obsoletis. Act. Soc. Linn. 8. p. 53. pl. 1. f. 8.

Shell suborbicular, with minute, obsolete, transverse stria.

Pult. in Hutch. Dorset. pl. 5. f. 5. Donov. Brit. Shells, pl. 98. Mont. Test. Brit. p. 64. Penn. Brit. Zool. 1812. 4. p. 181.

A thickish, milk-white shell, somewhat diaphanous, smooth, and depressed; margins rounded on both sides; very smooth and yellowish within; primary tooth of the hinge bifid; lateral teeth strong, that in the right valve more solid and remote than the other. Length an inch and a quarter; breadth an inch and three eighths.

This is a very rare British shell, dredged up at Weymouth, under the inspection of the late Duchess Dowager of Portland, and first described by Dr. Pulteney. It does not appear to be the species figured by Lister, Born, and Chemnitz, though all those authors have been referred to for this shell. 
THICK TELLEN.

Pl. 40. f. 1.

75. Tellina crassa. T. testa subrotunda, depressa, sulcis transversalibus numerosissimis. Act. Soc. Linn. p. 55.

Shell roundish, depressed, with numerous transversal furrows.

List. Conch. pl. 299. f. 136. Penn. Brit. Zool. 4. pl. 48. f. 28. Da Costa Brit. Conch. pl. 13. f. 4. Pult. in Hutch. Dorset. pl. 7. f. 4. Mont. Test. Brit. p. 65. Donov. Brit. Shells, pl. 103.

A thick, strong, suborbicular shell, of a white colour, strongly striated concentrically, and sometimes marked with faint, reddish, longitudinal rays: one valve is more convex than the other; both ends are rounded, but one end is more extended than the other; the apex turns inwards. The inside is white, or yellowish, or blushing; hinge with two small primary teeth; one lateral tooth in the shallow valve, and two in the deep valve; the strong tooth nearest the hinge. Length an inch and three quarters; breadth two inches and an eighth; seldom much larger, but often smaller.

Inhabits the British shores, but is not common in a live state, or with both valves perfect. It is found on the Devonshire, and Cornish coasts, at Weymouth, and in Wales; single valves are not uncommon upon the Sandwich shore.

This shell was first figured, very admirably, by Lister, who procured his specimen from Guernsey. Gmelin has erroneously called it a Venus. See Syst. Nat. p. 3288. It is the Pectunculus depressior of Da Costa, and the $\boldsymbol{T}$. rigida of Dr. Pulteney, and Mr. Donovan. 
MILKY TELLEN.

76. Tellina lactea. T. testa lentiformi, gibba, alba, pellucida, lavi. Linn. Syst. Nat.ed.12. p. 1119. Linn. Gmel. p. 3240.

Shell lens-shaped, gibbous, white, pellucid, smooth.

Gualt. Test. pl. 71. f. D. Chem. Conch. 6. pl. 13. f.125. Pult. in Hutch. Dorset. pl. 5. f. 9. Mont. Test. Brit. p. 70. pl. 2. f. 4. Linn. Trans. 8. p. 56. Penn. Brit. Zool. 1812.4. p. 182.

A thin, convex, orbicular, white shell, marked with obsolete, transverse stria, and a few antiquated ridges. Inside white; hinge furnished with two very small teeth in one valve, and one in the other; a deep furrow runs from the apex, by the side of the teeth, in each valve. Length about three quarters of an inch; breadth the same.

Inhabits the Mediterranean, and is found, though not commonly, on several parts of the shores of Great Britain. Live shells are very rare in England.

\section{ROUND TELLEN.}

77. Tellina rotundata. T. testa subconvexa, orbiculari, valvulis bidentatis, dente altero bifido, altero divergente. Act. Soc. Linn. 8. p. 56.

Shell orbicular, and somewhat convex; two teeth in each valve, one bifid, the other rather diverging.

Pult. in Hutch. Dorset. pl. 5. f. 8. Mont. Test. Brit. p. 71. pl. 2. f. 3. Penn. Brit. Zool. 1812. 4. p. 182.

A subdiaphanous, white shell, marked with nearly obsolete, transverse striæ; the apex is small, and turned a little on one side. Inside white and very smooth. Length an inch.

Inhabits the British shores, at Poole in Dorsetshire, and on the Western coasts, but is rarely found 
perfect. It is very like the Venus undata, but has not, like that shell, three teeth in one valve. It is the $\boldsymbol{T}$. undata of Dr. Pulteney.

\section{CROOKED TELLEN.}

Pl. 47. f. 7, 8.

78. Tellina flexuosa. T. testa subgloboso-tenerrima, sinu ab umbone ad marginem decurrente. Act. Soc. Linn. 8. p. 56.

A very thin, somewhat globular shell, with a furrow running from the umbo to the margin.

Donov. Brit. Shells, pl. 42. f. 2. Mont. Test. Brit.p. 72. Penn. Brit. Zool. 1812. 4. p. 183.

This is a very small, brittle, snow-white shell, with a crooked margin, and a remarkable furrow running from behind the apex to the posterior margin of the shell, where it forms a flexure. The hinge has an obsolete tooth. Length about three eighths of an inch.

Inhabits the south coast of Devonshire, and is found, abundantly, in the sand of Falmouth harbour. It has also been found at Tenby. This species is the Venus sinuosa of Donovan. It was discovered by Mr. Montagu. 
FLESH-COLOURED TELLEN.

Pl. 40. f. 4, 5. Dr. Соомве.

79. Tellina carnaria. T. testa suborbiculata, levi, utrinque incarnata, oblique striata, striis hinc reflexis. Linn. Syst. Nat.ed.12. p. 1119. Linn. Gmel. p. 3240.

Shell somewhat orbicular, smooth, flesh-coloured (or rosy) within and without, and marked with oblique, reflected striæ.

List. Conch. pl. 339. f. 176. Born Test. pl. 2. f. 14. Chem. Conch. 6. pl. 13. f. 126. Donov. Brit. Shells, pl. 47. Mont. Test. Brit. p. 73. Linn. Trans. 8.p. 57. Penn. Brit. Zool. 1812.4. p. 183.

A light rose-coloured, orbicular shell, somewhat compressed, and marked with numerous, very fine, reflex striæ, running obliquely on the anterior margin, and in an undulating manner on the posterior margin; the intermediate striæ pass obliquely from the apex to the fore part of the shell. Inside smooth and glossy, with two teeth in one valve, and one in the other; lateral teeth remote. Length near an inch; breadth the same.

Inhabits the American Ocean, and has been found in England, but not recently. 


\section{POLYGONAL TELLEN.}

80. Tellina polygona. T. testa alba, transversim striata, orbiculari, antrorsum angulata; cardinis dentibus lateralibus nullis, primario exporrecto, duplicato, alterius duobus. Linn. Gmel. p. 3244.

Shell white, transversely striated, orbicular, the fore part angular; hinge without lateral teeth; primary tooth projecting and double; in one valve two teeth.

Chem. Conch. 10. pl. 170. f. 1650-1653.

Mont. Test. Brit. Suppl. p. 27. pl.28. f. 4. Penn. Brit. Zool. 1812.4. p. 185.

This species, which is not only angular before, but in the middle of the shell, is described by Chemnitz, under the name of $\boldsymbol{T}$. Guinaica. Mr. Montagu has also referred a small, rare, British shell, taken off Cramond Island, in the Frith of Forth, to the same species.

Foreign specimens inhabit the Indian Ocean, and are an inch and a half in breadth; the British shell is not more than a third the size.

\section{DECUSSATED TELLEN.}

Pl. 43. $f$. 2, 3. Linnean Society's Cabinet.

81. Tellina decussata. T. testa suborbiculata, delicatissime decussatim striata; intus alba, cum lituris brunneis, vel purpureis variegata.

Shell suborbicular, with very delicate decussated striæ; within white, variegated with brown, or purple streaks.

This is a whitish shell, with a faint rosy tip; it is rounded at both ends, but the fore part is produced, like the $\boldsymbol{T}$. crassa; the surface is finely striated transversely, and crossed by delicate longitudinal striæ: the inside is white, marked with zig-zag lines of a red 
brown, purple, or pale rose colour; the lines do not extend, in the specimens we have had an opportunity to examine, to the margin of the shell. Length an inch; breadth near an inch and a quarter.

Its country is not known.

\section{HEART-SHAPED TELLEN.}

Pl. 43. $f .4$, 5. Linnean Society's Cabinet.

82. Tellina cordiformis. T. testa suborbiculata, extus albida, intus favescente, longitudinaliter densissime, transversim subtilissime striata; cardinis dentibus primariis binis, lateralibus oblongis.

Shell suborbicular, on the outside whitish, within yellow, densely striated longitudinally, and very finely transversely; hinge with two primary teeth, lateral teeth oblong.

Chem. Conch. 11. pl. 199. f. 1941, 1942.

This species, which is of a dull, yellowish-white colour on the outside, and deep yellow within, is admirably figured by Chemnitz. It is a strong shell, and very convex. Length near an inch and a half; breadth rather more.

It is named $\boldsymbol{T}$. demissa, in the late Dr. Pulteney's Cabinet of Shells, now in the Linnean Society's Museum. 
Pl. 45. f. 6, 7. Mr. Sow ERBY.

83. Tellina bimaculata. T. testa triangulo-subrotunda, latiore, lavi, albida; intus maculis duabus sanguineis oblongis. Linn. Syst. Nat. ed. 12. p. 1120. Linn. Gmel. p. 3240.

Shell triangularly rounded, broad, smooth, and whitish, with two oblong red spots on the inside.

Da Costa Brit. Conch. p. 213. Chem. Conch. 6. pl. 13. f. 127. Encyclop. Method. pl. 290. f. 9. Pult. in Hutch. Dorset. pl. 5. f. 7. Donov. Brit. Shells, pl. 19. f. 1, 2. Mont. Test. Brit.p. 59. Linn. Trans. 8. p. 57. Penn. Brit. Zool. 1812. 4. p. 183.

ß. Chem. Conch. 6. pl. 13. f. 132. Encyclop. Method. pl. 290. f. 10.

This is a whitish, subdiaphanous shell, indistinctly striated transversely, and marked within with two oblong red spots, or lines, which are continued more than half-way down the shell ; the hinge has a double primary tooth in the centre; the lateral teeth are strong and remote. Length half an inch; breadth five eighths of an inch.

Inhabits the European and American seas, and has been noticed as English, by Da Costa, from the coasts of Hampshire and Lancashire, and by Dr. Pulteney, and Mr. Bryer, who found it on the shore, between Weymouth and Portland.

This species is subject to variation; sometimes it is uniformly purple, or white, and sometimes rayed with several red lines, in which state it is the var. $\beta$. of Chemnitz. 
SOLID TELLEN.

Pl. 46. f. 2.

84. Tellina solidula. T. testa subglobosa, anterius subangulata. Act. Soc. Linn. 8. p. 58.

Shell subglobose, and somewhat angular before.

Bonan. Recr. 2. f. 44. Mus. Kirch. 2. f. 43. Lister Anim. Angl. pl. 4. f. 25. - Conch. pl. 405. f. 250. Petiv. Gaz. pl. 94. f. 6. Da Cost. Brit. Conch. pl. 12. f. 4. Chem. Conch. 6. pl. 12. f. 110. Pult. in Hutch. Dorset. pl. 8. f. 4. Mont. Test. Brit. p. 63. Penn. Brit. Zool. 1812. 4. p. 184. pl. 52. f. 2.

A very strong, convex shell, nearly orbicular, but projecting into a short, compressed beak, at one end: the surface is smooth, and either plain, or variegated with concentric bands of red, yellow, or whitish colours. The inside, which is smooth, is either red, white, or yellow, and generally of a deeper tint than the outside: the hinge has two small teeth in each valve. Length near an inch; breadth rather more.

Inhabits the European ocean, and is common on the sandy shores of Great Britain, buried a few inches beneath the surface.

This species was mistaken by Pennant, for the $\boldsymbol{T}$. carnaria of Linnæus, and Gmelin has referred it to the $\boldsymbol{T}$. incarnata of that celebrated naturalist; but we have reason to suppose the $\boldsymbol{T}$. incarnata of Linnæus to be the same as $\boldsymbol{T}$.tenuis. 
BALTIC TELLEN.

85. Tellina Balthica. T.testa subrotunda lavi, extus incarnata. Linn. Syst. Nat.ed.12. p. 1120. Linn. Gmel. p. 3241.

Shell roundish, smooth, and flesh-coloured on the outside.

Chem. Conch. 6. pl. 13. f. 128.

A thin, brittle, pellucid, compressed shell, of a somewhat triangular shape; white within, and flesh coloured, or rosy, on the outside; hinge the same as in $T$. carnaria. It is the size of a lupine seed.

Inhabits the Baltic sea.

PEA TELLEN.

86. Tellina pisiformis. T. testa subglobosa, lavi, intus incarnata, oblique substriata; striis anterius angulo acuto reflexis. Linn. Syst. Nat.ed.12. p. 1120. Linn. Gmel. p. 3241.

Shell subglobular, smooth, within carnation, somewhat striated obliquely, striæe reflected into an acute angle on the fore part.

A white shell, with a purple tip; the striæ are hardly visible to the naked eye; primary tooth of the hinge simple, lateral teeth rather prominent. It is the size of a pea.

Inhabits the European ocean, at the mouths of rivers. 


\section{OBLIQUELY STRIATED TELLEN.}

\section{$P l$. 46. f. 6. Mr. SOW ERBY.}

87. Tellina divaricata. T. testa subglobosa, alba, bifariam oblique striata. Linn. Syst. Nat. ed.12. p. 1120. Linn.Gmel.p. 3241. Shell somewhat globular, white, and obliquely striated two ways. Bonan. Mus. Kirch. 2. f. 104. List. Conch. pl. 301. f. 142. Petiver Gaz. pl. 156. f. 26. Favanne Conch. pl. 48. f. E. Chem. Conch. 6. pl. 13. f. 129.

A strong shell, rather globular, and generally of a whitish colour, rarely blue, or cinereous; the striæ, on the surface of the shell, are thin, waved, and diverging both ways; the margin is crenated, and without any flexure; there is a double primary tooth at the hinge, but no lateral teeth. Length near an inch; breadth rather more.

Inhabits the Mediterranean and American seas.

\section{TOOTHED TELLEN.}

Pl. 46. f. 7. Mrs. Mawe,

88. Tellina dentata. T. testa subglobosa, alba, margine dentata, bifariam oblique striata.

Shell somewhat globular, white, margin toothed, obliquely striated two ways.

This shell, though resembling the precering species in several respects, is certainly distinct, and differs in the following particulars. The upper part of the margin is strongly dentated, particularly the posterior edge; the rest of the circumference is serrated; the concentric striæ are somewhat raised from the surface of the 
shell, and, like the margin, have serrated edges; the waved striæ, on the surface, are finer, and closer than in the $\boldsymbol{T}$. divaricata. The umbones are prominent, and turn inwards.

This elegant shell is in the cabinet of Mrs. Mawe.

\section{DIGITAL TELLEN.}

89. Tellina digitaria. T. testa subglobosa, pallida, cincta siriis obliquis uniformibus. Linn. Syst. Nat. ed.12. p. 1120, Linn. Gmel. p. 3241. Shell subglobose, pale, and girded with oblique uniform striæ.

Chem. Conch. 6. pl. 2. f. 120, 121. Encyclop. Method.pl. 292. f. 5, 6.

A small species, smooth on the inside, and varying in colour, sometimes being reddish-orange, and sometimes pointed with waved, red, spots; the striæ inclined towards the outer margin, like the lines at the ends of the fingers, (whence its trivial name) which gives it the appearance of being spirally striated. It is about the size of a pea.

Inhabits the Mediterranean, American, and (very rarely) the Indian seas.

\section{HORN-COLOURED TELLEN.}

Pl. 46. $f$. 3.

90. Tellina cornea. T. testa globosa, glabra, colose corneo, sulco transversali. Linn. Syst. Nat. ed. 12.p. 1120. Linn. Gmel. p. 3241.

Shell globose, smooth, of the colour of horn, and transversely sulcated.

List. Anim. Angl. pl. 2. f. 31.-App. pl. 1. f. 5. - Conch. pl. 159. f. 14. Gualt. Test. pl. 7. f. C. Argenv. Conch.pl. 27. f. 9. Penn. Brit. Zool. 1812. 4. pl.52. f. 3. Da Costa Brit. Conch. pl. 13. f. 2. Chem. Conch. 6. pl.13. f. 133. a. b. Maton in Act. Soc. Linn. 3. pl. 13. f. 39, 40. Pult. in Hutch. Dorset. pl. 7. f. 2. Donov. Brit. Shells, pl. 95. Mont. Test. Brit. p. 86. Linn. Trans. 8. p. 59.

A thin, globose, horn-coloured shell, concentrically 
striated, and covered, when recent, with a thin epidermis ; the inside is smooth, glossy, and of a bluish-white; the primary teeth of the hinge are very minute, the lateral teeth remote and prominent. It is, commonly, about the size of a large pea.

Inhabits the rivers, ponds, and ditches, of Europe. The largest are found in the Thames, and in great abundance, es pecially at the Red-house, opposite the end of Mill-bank, where, at low water, any quantity may be procured, from half to three quarters of an inch in breadth. Mr. Montagu has removed this, and the following shell, to the genus Cardium.

\section{LAKE TELLEN.}

\section{$P l$. 47.f. 5. Mr. SoWERBY.}

91. Tellina lacustris. T. testa rhombea, planiuscula, glabra, umbone acuto. Linn. Gmel. p. 3242.

Shell rhombic, flattish, smooth, with an acute umbo.

Mull. Verm. p. 204. No. 388. Chem. Conch. 6. pl. 13. f. 135.

Encyclop. Method. pl. 292. f. 3. Mont. Test. Brit. p. 89. Linn.

Trans. 8. p. 60. Penn. Brit. Zool. 1812.4. p. 184.

A smooth, thin, pellucid, horn-coloured shell, often covered with a dark brown epidermis; it is broader than long, and the valves near the margin are depressed; the umbo, or apex, is small, but so remarkably prominent, as to give the shell a heart-shaped appearance when seen sideways; the hinge has a simple primary tooth in one valve, and a cleft tooth in the other, with lateral teeth in both valves. It is about the size of a pea.

Inhabits the lakes and marshes of Europe. It was discovered, as a British shell, by Mr. Swainson, and 
has since been found, abundantly, by Mr. Monțagu, in a small pond near the village of Wedhampton, in Wiltshire. It differs from $\boldsymbol{T}$. cornea in its subrhomboidal shape, projecting umbones, and compressed margin.

\section{SPANISH TELLEN.}

92. Tellina Iberica. T. testa globosa, lcevi, nitida, margine dentata. Linn. Gmel. p. 3243.

Shell globular, smooth and polished, with a toothed margin.

Bonan. Recr. pl. 2. f. 33. - Mus. Kirch. 2. f. 32.

A small, thin shell, of a russet brown colour, sometimes yellowish-brown mixed with black. It has a projecting apex, and is about five eighths of an inch broad.

Inhabits the shores of Spain. The $\boldsymbol{T}$. Adriatica of Gmelin, for which he has referred to Bonanni, Recreat. pl. 2. f. 34. is only the interior view of the same shell.

\section{SINUOUS TELLEN.}

93. Tellina sinuosa. T. testa subglobosa, aquivalvi, aquilatera; stviis transversis rarioribus. Linn. Gmel.p. 3243.

Shell subglobular, of equal valves, and equal sides, with a few transverse stria.

Gualt. Test. pl. 77. f. D. E.

A shell about the size of a marble, of a whitish, or reddish colour, and very faintly striated.

Gualtieri's figure D. resembles the $\boldsymbol{T}$. lactea. 
FRENCH TELLEN.

94. Tellina Gallica. T. testa trigona, pectinata. Linn. Gimei. p. 3244. A triangular, pectinated shell. Argenv. Conch. pl. 27. f. 11.

A thickish shell, striated, or rather sulcated, longitudinally ; the hinge has a solitary primary tooth. It is about three quarters of an inch broad.

Inhabits the river Marne, in France.

\title{
SENEGAL TELLEN.
}

95. Tellina Senegalensis. T. testa trigono-globosa, crassa, dura, lavi, sulcis transversis exarata. Linn. Gmel. p. 3244.

Shell of a triangular globose shape, thick, strong, and smooth, with transverse grooves.

Adans. Seneg. pl. 17. f. 14. (Tofar.)

A white, or flesh-coloured shell, sometimes red, rayed with white.

Inhabits Africa.

\author{
MATON'S TELLEN. \\ Pl. 46. $f .4,5$. Dr. Maton.
}

96. Tellina limosa. T. testa aquivalvi, ovata, transversim striata, intus purpurea; umbonibus acutiusculis, prominentibus. Maton in Act. Soc. Linn. 10. p. 328. pl. 24. f. 8, 9, 10.

Shell of equal valves, oval, transversely striated, and purple within; umbones sharpish, and prominent.

This is a smooth, brittle shell, with a green epidermis ; the margin is entire; the hinge has two primary teeth in one valve, and one in the other; the lateral 
laminæ are crenated. Young shells are paler, thinner, and somewhat diaphanous. Length half an inch, breadth three quarters.

Inhahits the South American rivers.

We are indebted to Dr. Maton for our knowledge of this singular shell, and for the use of his specimen, from which our figure has been engraved and coloured. There are three different views of a shell, in the Encyclop. Method. pl. 302. f. 2. a. 2. b. and 2. c. which resemble this but not sufficiently to pronounce them the same. The peculiarity which at once distinguishes this species from others of the genus Tellina, is the crenated lateral laminæ, which are plainly to be seen with the assistance of a lens. The French have arranged shells of this description in a new genus, under the name of Cyclas. 


\section{******* Shells Plano-conver.}

\section{UNEQUAL-VALVED TELLEN.}

Pl. 47. f. 2, 3, 4. Mr. Sowerby.

97. Tellina inæquivalvis. T. testa oblongo-rostrata, valvula altera plana, Linn. Syst. Nat. ed. 12. p. $1118 . \quad$ Linn. Gmel. p. 3233.

Shell oblong, beaked, one valve flat.

Chem. Conch. 6. pl. 11. f. 106. a.b. c. d. Encyclop. Method. pl. 250. (Pandora) Donov. Brit. Shells, pl. 41. f. 1. Mont, Test. Brit. p. 75. Linn. Trans. 8. p. 50. Penn. Brit. Zool. 1812. 4. p. 178.

A smooth, pellucid, milky shell, with one valve flat, and the other convex; one end is rounded, the other produced into an obtuse beak; the dorsal suture is straight; there are two teeth at the hinge, but no lateral teeth. Length, (of large specimens, three quarters of an inch; breadth an inch and a half.

Inhabits the Mediterranean and Norwegian seas, and has been admitted among the British species, by Mr. Donovan, on the authority of a specimen from Guernsey. Mr. Montagu suggests, in the supplement to his British Testacea, that his Solen Pinna may be the young of this species; but the figure which that naturalist has given, and which is undoubtedly correct, will hardly justify the conjecture. The Author has before him a young $\boldsymbol{T}$. incequivalvis, not more than a quarter of an inch long, and five eighths broad, exactly proportioned like the largest specimens.

The French naturalists have constituted of this shell a new genus, under the name of Pandora of which this, the $\boldsymbol{P}$. margaritacea, is the only species. 
The want of similitude between this and other Telline is so obvious, that it will justify the innovation. It stands among the Solenes, in the tenth edition of the Syst. Nat., whence, in a future edition, Linnæus removed it to its present situation,

Gmelin's T. Bornii, p. 3231. No. 15, is the T. Ferröensis; his $T$. complanata, p. 3239. No. 60 . is the true $T$. planata, p. 3232. No. 19 ; but his reference to Chemnitz, for that shell, must be rejected. $T$. vitrea, $p$. 3255. No. 34, is a variety of our T. tenuis. T. alata, p. 3236. No. 40. is a Mytilus. T. rhomboides, p. 3237. No. 50. is the Venus decussata; the specification is abridged from Lister's Animalium Anglia, p. 171. who says, ad ostium fluminis Tees, ripâ Eboracensi, satis frequenter reperiuntur. Gmelin has omitted the word ostium, which is essential. $T$. vinacea, p. 3238, No. 51. is a Donax. T. zonata, p. 3238. No. 52. is the $T$. tenuis. T. fuminalis, fluminea, and fluviatilis, p. 3242. No. 79, 80, and 81 . are placed, with more propriety, by Chemnitz, in the genus Venus. T. purpurata, p. 3243. No. 86, and $T$. purpurascens, p. 3237. No. 45, are not distinct, species. 


\section{Genus 4.}

\section{CARDIUM. \\ GENERIC CHARACTER.}

Animal Tethys.

Testa bivalvis, subrequilatera, æquivalvis.

Cardo dentibus mediis binis alternatis; lateralibus remotis, insertis.

Animal a Tethys.

Shell bivalve, nearly equilateral, and of equal valves. Hinge with two primary teeth, alternating with the opposite; lateral teeth remote, and inserted.

GENERAL OBSERVATIONS.

Bruguiere observes, that Langius, who is the first Testaceological writer upon whose nomenclature any dependance can be placed, has described all the shells of this genus, under the collective title of Concha cordiformes. D'Argenville, afterwards, adopted the denomination of this author, and gave the name of heart to every shell bearing any external resemblance to that organ.

But the generic character of Langius is insufficient, since it does not apply to every species of the genus; and that of D'Argenville is excessive, since it not only includes the Cockles, but also such shells of the genus Chama, Arca, and even Venus, as have any tendency to the shape of a heart.

This genus, such as Linnæus has left it in the twelfth edition of his Systema Natura, is founded on the num- 
ber and situation of the teeth of the hinge; and although it includes none but analogous species, yet the number, owing to the researches of subsequent authors, and the consequent advancement of the study, is augmented to more than double the number described by Linnæus. There are, generally, four teeth in each valve, two of which are situated close to the apex of the shell, and are called by Linnæus cardinal teeth; the other two, or lateral teeth, are remote, and all four lock into corresponding cavities in the opposite valve. Nearly all the species of this genus are longitudinally ribbed.

It must be observed, that we find in authors, the most exact in other respects, a singular abuse of terms in their designation of the ribs of cockles. Almost every one, not excepting Linnæus, has called them sulci, which signifies grooves, and is in direct contradiction to the fact, the ribs being a raised, not a depressed surface. Baron Born was the first to rectify this error, who, regardless of preceding authorities, was determined to make the just distinction between ribs and furrows. It will be proper to remark that, in the following specifications, in conformity with Baron Born's correction, we have constantly substituted costa for sulcus, wherever Linnæus has used the latter word improperly.

The animal inhabiting the Cockle, has two very short tubes, which project from the anterior, and upper part of the body; the lower tube is the longest, and is provided with a pendent valve, by which it may be closed; both tubes are crowned with about thirty filaments, disposed in two rows, of which those of the outer row are conical, and stronger than the others. There is a fleshy limb, shaped like an arm, with an elbow in the middle, which proceeds from the body of the animal, and which 
can be projected considerably beyond the moath of the shell; the fore part of this fleshy arm, when extended, forms nearly a right angle with the mouth of the shell, and is the organ by means of which the animal executes its confined progressive motions.

Cockles generally bury themselves in the sand, near the coasts, except the spiny species, which are capacitated, by nature, to defend themselves from the attacks of other marine animals, without having recourse to the same precaution. Those which seek their safety in the sand place themselves so, that the two tubes are turned towards the surface, for the purpose of a ready communication with the water, whence they derive their nourishment. But it is sometimes necessary for them to change their situations, to leave their old apartments, or to bury themselves in a new one; and this is effected, according to the observations of M. Reaumur, in the following manner: When the animal wishes to sink into the sand, it lengthens its fleshy arm, at the same time diminishing its extremity, so that it becomes as it were pointed. With this it makes a hole, and buries the arm in the sand, continuing its mining operations with the pointed end; and by repeatedly lengthening and contracting this muscular appendage, it in a short time works the shell below the surface. When on the contrary the animal would return to the light, it is only necessary to press its lengthened arm, with firmness, against the sand, and the shell will rise in proportion to the power exerted from beneath; by repeating this motion, the shell will soon be disengaged, and the animal will effect its purpose. By the same means the animal is enabled to move both forwards and backwards, but in a very limited degree. 
Cockles are found in all the known seas, and we meet with many species in a fossil state.

Poli, in his Testacea of the two Sicilies, has constituted a new genus of these shells, under the name of Cerastes, and has given some very accurate anatomical details of the animal, in pl. 26. No. 5, and following. 
Pl. 48. Mr. Sowerby. Pl. 51. $f$. 1. Dr. Соombe.

1. Cardium aculeatum. C. testa subcordata, costis convexis linea exaratis, exterius aculeato-ciliatis. Linn. Syst. Nat. ed. 12. p. 1122. Linn. Gmel. p. 3247.

Shell somewhat heart-shaped; ribs convex, and marked with a line; spiny on the outside.

Testa subcordata obliquata, costis convexis linea exaratis, spinosis aculeatis. Brug. Encyclop. Method. Hist. Nat. tom. 6. p. 216.

List. Conch. pl. 321. f. 158. Bonan. Recr. 2. f. 96. Mus. Kirch. f. 97, 98. Gualt. Test. pl. 72. f. A. Seba Mus. 3. pl, 86. f. 4. Knorr Vergn. 6. pl. 3. f. 1. Argenv. Conch. pl. 23. f. B. Favanne Conch. pl. 52. f. A. Penn. Brit. Zool. 4. pl. 50. f. 37. Chem. Conch. 6. pl. 15. f. 155-15\%. Encyclop. Method. pl. 298. f. 1. Donov. Brit. Shells, pl. 6. Mont. Test. Brit. p. 77. Linn. Trans. 8. p. 62.

ß. Sowerby, Brit. Miscel. p. 65. pl. 32.

A strong, convex shell, of a tawny, or yellowish brown colour, with transverse bands of a different shade; the ribs are about twenty in number, strong, convex, grooved down the middle, and furnished with slit spines on one side the shell, and tubercles on the other. The inside is whitish, or flesh-coloured, with flat ribs corresponding with the furrows on the outside; the hinge has two primary teeth in one valve, and one in the other; the lateral teeth are strong, and prominent. It varies in size, and the young shells are much thinner, and have longer spines. In this state it is the variety $\beta$, or $\mathrm{Car}$ dium spinosum, of Mr. Sowerby.

Inhabits the European and Mediteranean seas, and was first figured as a British shell by Pennant, who says it is found in Scotland, off the Hebrides and 
Orknies. Mr. Montagu has met with it on the coast of South Devonshire, particularly on Dawlish Warren, and at Tor-cross.

Fig. 1. pl. 51. is the exotic variety of this species. It is of a tawny colour, and more closely set with spines and knobbs, than our shell. It inhabits the Indian ocean, and is well figured by Chemnitz, vol. 6. pl. 15 . f. 157.

\section{THORNY COCKLE.}

Pl. 49. f. 1, 2.

2. Cardium echinatum. T. testa subcordata, costis exaratis, linea ciliata, aculeis inflexis plurimis. Linn. Syst. Nat. ed. 12. p. 1122. Linn. Gmel. p. 3247.

Shell somewhat heart-shaped, ribs lineated down the middle, spines for the most part inflected.

Testa cordato-ovata, subaquilatera, costis confertis, linca exaratis, aculeis inflexis numerosis. Brug. Ency. Meth. Hist. Nat. 6. p. $21 \%$.

List. An. Aug. pl. 5. f. 33. - Conch. pl. 324. f. 161. Bonan. Recr. 2. f. 90. Seba Mus. 3. pl. 86. f. 3. Murray in Amoen. Acad. pl. 2. f. 19. Muller Zool. Dan. p. 46. pl. 13. f. 12. and pl. 14. f. 1-4. Da Costa, Brit. Conch. p. 176. pl. 14. f. 2. Chem. Conch. 6. pl. 15. f. 158. Encyclop. Method. pl. 298. f. 3. Pult. in Hutch. Dorset. pl. 6. f. 2. Donov. Brit. Shells, pl. 107. f. 1. Mont. Test. Brit. p. 78. Linn. Trans. 8. p. 63.

A smaller shell than the preceding, of a dull whitish, or yellowish-brown colour, with nineteen longitudinal ribs, set with white, enameled spines, some erect, and others inflected ; intermediate furrows deep, and transversely striated. The inside white, with flat ribs ; hinge with four teeth in each valve, two approximate, and two remote; each of the remote, or lateral teeth, in one valve, have an interior depression, which receives the 
point of the opposite tooth. Length about two inches; breadth about two and a quarter.

Inhabits the Northern ocean, and is common on most of the British shores. Live shells are seldom taken, except by dredging.

The C. echinatum was first noticed by Lister, whose figure is very accurate. The Linnæan reference to Gualtieri, pl. 72. f. B. is wrong, that shell is a young specimen of the $C$. aculeatum. The $C$. ciliatum Linn. Gmel. p. 3248. No. 10. is the C.echinatum in a young state.

\section{FRINGED COCKLE.}

\section{Pl. 49. f. 3, 4. Mr. Soweriy.}

3. Cardium ciliare. C. testa subcordata, costis elevatis triquetris, extimis aculeato-ciliatis. Linn. Syst. Nat. ed. 12. p.1122. Linn. Gmel. p. 3248.

Shell somewhat heart shaped; ribs raised and triangular, with thin spines at the end.

List. Conch. pl. 325. f. 162. Gualt. Test. pl. 72. f. C. Knorr Vergn. 6. pl. 5. f. 5. Penn. Brit. Zool. 1812. 4. pl. 53. f. 2. Chem. Conch. 6. pl. 17. f. 171, 172. Encyclop. Method.pl. 298. f. 4. Pult. in Hutch. Dorset. pl. 4. f. 1. Donov. Brit. Shells, pl. 32. f. 2. Mont. Test. Brit. p. 79, Linn. Trans. 8. p. 64.

A very thin, orbicular shell, of a white, or yellowish colour, with about nineteen sharp ribs, crowned with flat triangular spines; the furrows are smooth, flat, and glossy. Length seven eighths of an inch; breadth an inch.

Inhabits the European and Mediterranean seas. It is rare in England, but has been found on the Dorset coast, by Dr. Pulteney, and in Cornwall and Devonshire, by

vOL. I. 
Mr. Montagu. Mr. Donovan mentions it from the Orknies. The C. ciliare of Chemnitz, 11. pl. 200. f. 1951, does not sufficiently accord with the above, to be placed among the synonyms.

TUBERCULATED COCKLE.

Pl. 50. f. 1, 2. Mr. SowerBY.

4. Cardium tuberculatum. C. testa subcordata, costis obtusis, nodosis, transversim striatis. Linn. Syst. Nat. ed. 12. p. 1122. Linn. Gmel. p. 3248.

Shell somewhat heart-shaped, ribs obtuse, knotty, and transversely striated.

List. Conch. pl. 329. f. 166. Gualt. Tcst. pl. 71. f. M. Seba Mus. 3. pl. 36. f. 7. Chem. Conch. 6. pl. 15. f. 173. and pl.19. f. 191 . Pult. in Hutch. Dorset. pl. 2. f. 2. Donov. Brit. Shells, pl. 107. f. 2. Mont. Test. Brit. p. 79. and p. 568. Linn. Trans. 8. p. 64.

A strong, rust-coloured, banded shell, the size and shape of the C.echinatum; the ribs are remote, obtuse, and, as well as the furrows, are strongly striated transversely : the sides, and extremity of the shell, are somewhat knotty.

Inhabits the Mediterranean, and British sea, where it was first noticed, on the Dorset coast, by Dr. Pulteney, and has been since found at the mouth of the $\mathrm{Ex}_{\mathrm{x}}$, in Devonshire, by Mr. Montagu. It greatly resembles the C. echinatum, but is longer in proportion to its breadth, and has never been found with spines. 
MARBLED COCKLE.

Pl. 50.f. 3. Mrs. MAWE.

5. Cardium medium. C. testa subcordata, subangulata, valvis angulatis, sulcatis, striatis. Linn. Syst. Nat. ed.12. p.1122. Linn. Gmel. p. 3246.

Shell somewhat heart-shaped, subangular, the valves angular, grooved, and striated.

Testa subcordata, antice utrinque carinata, costis longitudinalibus convexis, transversim dupliciter striatis. Brug. Encyc. Meth. Hist. Nat. 6. p. 213.

List. Conch. pl. 316. f. 153. Bonan. Recr. 2. f. 94. — Mus. Kirch. 2. f. 91. Gualt. Test. pl. 83. f. B. Knorr Vergn. 2. pl. 29. f. 5. and 5. pl. 20. f. 5. Spengler Conch. pl. 1. f. $k$. Chem. Conch. 6. pl. 16. f. 162-164. Encyclop. Method. pl. 96. f. 1. Donov. Brit. Shells, pl. 32. f. 1. Mont. Test. Brit. p. 83. Linn. Trans. 8. p. 61. Penn. Brit. Zool. 1812. 4. p. 186.

A strong, heart-shaped shell, waved, and angular, or truncated, before; of a whitish colour, marbled or spotted with red, and dark brown; sometimes variegated with other colours; the ridges are numerous, and covered with very close set, curved striæ, which, when magnified, have the appearance of cat-gut, and give a roughness to the surface of the shell; inside generally white, but sometimes of a deep red; hinge with a single, erect, incurvated, primary tooth; lateral teeth strong, and prominent. About the size of a walnut.

Inhabits the Indian and American ocean, and also the coasts of the Antilles. It is figured in Donovan's British Shells, from a specimen found at Hartlepole, Durham, by the Rev. T. Rackett. 


\section{PIGMY COCKLE.}

6. Cardium exiguum. C. testa subcordata, subangulata, costis recurvato-imbricatis. Act. Soc. Linn. 8. p. 61.

Shell somewhat heart-shaped, subangular; ribs recurved and imbricated. Testa oblongiuscula, inaqualiter costata, subfusca. Linn. Gmel. p. 3255. List. Conch. pl. 317. f. 154. Walker Minut. Rarior. f. 83. Donov. Brit. Shells, pl. 32. f. 3. Pult. in Hutch. Dorset. pl. 2. f. 11. Mont. Test. Brit. p. 82. Penn. Brit. Zool. 1812. 4. p. 186.

A very small shell, about the size of a currant, of a white or ochreous colour, with twenty tuberculated ribs, and transversely striated furrows; inside white.

Inhabits the British shores, and was first found by Mr. Boys at Sandwich; also by Dr. Maton, and Mr. Montagu in Falmouth Harbour.

\section{KNOTTY COCKLE.}

7. Cardium nodosum. C. testa rotundata, compressa; costis 24, tuberculis numerosis, obtusis. Act. Soc. Linn. 8. p. 66.

Shell round, and compressed ; ribs 24, tubercles numerous, blunt. Mont. Test. Brit. p. 81. Penn. Brit. Zool. 1812. 4. p. 189.

A flat, somewhat orbicular shell, of a reddish white colour. The inside is white and glossy, the margin is strongly toothed. Diameter of the shell, about three quarters of an inch.

Inhabits the coast of Devonshire, and was discovered amongst some sand, from Falmouth Harbour, by $\mathrm{Mr}$. Montagu. 
RED COCKLE.

8. Cardium rubrum. C. testa rotundata, convexa; cardinis dentibus primariis fere obsoletis, lateralibus manifestis. Act. Soc. Linn. 8. p. 66. Shell round, convex: hinge with the primary teeth nearly obsolete, lateral teeth apparent.

Mont. Test. Brit. p. 83. Walker Minut. Rarior. $n^{0} .86$ ? Penn. Brit. Zool. 1812. 4. p. 189.

A minute species, about the eighth of an inch broad; smooth, pellucid, of a red colour, and rounded at both ends. Inside of a glossy red, with a plain margin.

Inhabits the British ocean. Was found at Sandwich by Mr. Boys, and on the Devonshire coast, at Falmouth, and particularly about Kingsbridge, by Mr. Montagu.

WAVED COCKLE.

9. Cardium arcuatum. C. testa orbiculari, transverse arcuatim striata. Act. Soc. Linn. 8. p. 67.

Shell orbicular, with transverse, arched strix.

Mont. Test. Brit. p. 85. pl. 3. f. 2. Penn. Brit. Zool. 1812. 4. p. 190.

A thin, brittle, semi-pellucid shell, of a white colour, marked with very fine arched, or waved, transverse striæ, and a few irregular concentric furrows. Inside rather glossy, with a slightly crenated margin; hinge with a single primary tooth in each valve; diameter nearly half an inch.

Inhabits Falmouth Harbour, but is not common.

This elegant species was discovered by Mr. Montagu, and resembles the Tellina divaricata. 


\section{PEA COCKLE.}

10. Cardiun discors. C. testa suborbiculari, maximè convexa, valvulis obliquè striatis. Act. Soc. Linn. 8. p. 67.

Shell somewhat orbicular, very convex; valves obliquely striated.

Mont. Test. Brit. p. 84. Penn. Brit. Zool. 1812. 4. p. 190.

A smooth, white shell, with oblique striæ running in acute angles, but so delicate as scarcely to be discerned by the naked eye; the hinge has a single primary tooth in each valve; lateral teeth remote. Size of a small pea.

Mr. Montagu is doubtful if this be an English shell, he having found but one dead specimen in the sand of Falmouth Harbour.

\section{LENGTHENED COCKLE.}

11. Cardium elongatum. C. testa angulato-subovali, compressa; costis 21 , rotundatis, leviter rugosis. Act. Soc. Linn. 8. p. 67.

Shell subangular, suboval, and compressed; ribs 21 , rounded, and faintly wrinkled.

Mont. Test. Brit. p. 82. Penn. Brit. Zool. 1812. 4. p. 190.

A small shell, about a quarter of an inch in diameter, of a yellowish-white, or light red colour, with the posterior side rather produced, and angular.

Discovered by Mr. Montagu, in Salcomb Bay, Devonshire. 
MICROSCOPIC COCKLE.

12. Cardium muricatulum. C. testa cordata, opaca, alba, margine muricato. Act. Soc. Linn. 8. p. 68.

Shell heart-shaped, opaque, white; margin spiny.

Mont. Test. Brit. p. 85. Walker Test. Minut. Rarior. f. 84. Penn. Brit. Zool. 1812. 4. p. 190.

A minute microscopic species, found in the sea sand of the Island of Sheppy, in Kent, where it is not uncommon.

\section{BANDED COCKLE.}

13. Cardium fasciatum. C. testa suborbiculari, pellucida; costis 27 , lavis, complanatis.

Shell suborbicular, pellucid; ribs 27 , smooth, and flattened.

Mont. Test. Brit. Suppl. p. 30. pl. 2\%. f. 6. Penn. Brit. Zool. 1812. 4. p. 190.

This is a small species about three eighths of an inch in diameter, slightly tuberculated at the shorter side, of a reddish white colour, with a few brown stripes, which also appear on the inside of the shell.

Discovered by Mr. Montagu on the Cornish and Devonshire coasts. 
14. Cardium muricatum. C. testa subcordata, sulcata, lateribus muricata. Linn. Syst. Nat. ed. 12. p. 1123. Linn. Gmel. 3250.

Shell somewhat heart-shaped, grooved, and prickly at the sides.

Testa cordato-ovata, subobliqua, cortis 36, lateribus lamelloso muricatis, marginibus utrinque sanguieneis. Brug. Encyc. Meth. Hist. Nat. 6. p. 233.

List. Conch. pl. 322. f. 159. Knorr Vergn. 4. pl. 14. f. 5. Chem. Conch. 6. pl. 17. f. 177.

ß. List. Conch. pl. 326. f. 163. Chem. Conch. 6. pl. 17. f. 178.

An oblong shell, of a cinereous, white, or yellowish colour, mixed, or spotted with red, the anterior side edged with scarlet; the ribs are thirty-six in number, on twelve of which the spines lean towards the posterior side of the shell, the rest recline in a contrary direction; the margin is denticulated, but the teeth are largest, and most open, at the anterior edge. The inside is white, with a tinge of scarlet at the anterior edge, and, sometimes, one or two brown, or orange stains near the hinge; the principal primary tooth pointed, and somewhat incurvated; the lateral teeth as usual. Length about two inches and a quarter; breadth, two inches.

This is one of the prettiest shells of the American ocean, both on account of the colours with which it is variegated, and the regular reclined disposition of the spines with which it is covered. It is found on the coasts of Jamaica, and St. Domingo. 


\section{IMBRICATED COCKLE.}

\section{Pl. 52. f. 1, 2. Mrs. Mawe.}

15. Cardium isocardia. C. testa cordata, costis squamis fornicatis, imbricatis. Linn. Syst. Nat. ed. 12. p. 1122. Linn. Gmel.p. 3249.

Shell heart-shaped, ribs with arched, imbricated, scales.

Bonan. Recr. 2. f. 95. - Mus. Kirch.2. f. 93. List. Conch. pl. 323.

f. 160. Rumph. Mus. pl. 48. f. 9. Petiver Gaz. pl. 152. f. \%. Rugenf. Conch. 1. pl. 5. f. 56. Born Test. p. 39. Vignette. Chem. Conch. 6. pl. 17. f. 174-176. Encyclop. Method. pl. 297. f. 4.

A strong, heart-shaped shell, of a whitish colour, spotted, or clouded, with brown; it has about thirtyfive longitudinal ribs, covered with erect, arched, hollow scales, placed one above the other, like the tiles of a house; inside white, purple in the middle; sometimes yellow; margin strongly denticulated; hinge with two primary teeth in each valve, one of which is very strong, erect, conical, and slightly incurvated; lateral teeth, in one valve, deeply excavated, to receive the points of their antagonists.

Inhabits the East Indies, the Persian Gulf, and the Red Sea; also the American ocean, on the coasts of Jamaica, and other West Indian islands. 


\section{GREENISH COCKLE.}

16. Cardium glaucum. C. testa cordata, subantiquata, antice glauca, costis viginti, postice retrorsum imbricatis, natibus violaceis. Poiret Voy. in Barbar. 2. p. 13. Linn. Gmel. p. 3253. Brug. Encyc. Meth. Hist. Nat. 6. p. 221.

Shell heart-shaped, somewhat worn, greenish before; ribs twenty, with imbricated scales turned backwards; umbones violet.

This is a small, heart-shaped shell, less than an inch in length, with twenty, or twenty-one, convex, longitudinal ribs; it is white, except the anterior part, which is greenish, and the tips, which are violet; the inside is brown before, and violet at the hinge; the posterior edges are white.

This is a very common species in the Mediterranean, particularly on the coasts of Languedoc, where it is so common, that Bruguiere is astonished it has escaped detection. It agrees with the $\boldsymbol{C}$. virgineum of Linnæus, in every thing except in the longitudinal ribs, which are wanting in the Linnæan shell. Poiret found it on the coast of Algiers.

MOTTLED COCKLE.

Pl. 52. f. 3. Mrs, MAWE.

17. Cardium maculosum. C. testa ovata, subcordata, maculis brunneis insignita: costis 48.

Shell oval, somewhat heart-shaped, and speckled with brown; ribs forty-eight.

Encyclop. Method.pl.298. f. 6 .

This shell is of an oval shape, and of a white colour, mottled with brown, or tawny; it has forty-eight deli- 
cate longitudinal ribs, four or five of which, on the anterior part of the shell, are finely tuberculated. The inside is white, marked with light purple, under the summit : the margin is serrated; the hinge has four teeth in each valve. Length an inch and an eighth; breadth an inch.

Country unknown.

From its shape and colour, this shell might be taken for the young of the $C$. magnum; but that it is decidedly different from that species, may be inferred from the number and appearance of the ribs. It is well figured in the Encyclopédie Méthodique; but the specimen in that work is larger than ours, being an inch and three quarters long, and an inch and a half broad.

\section{TOOTHED COCKLE.}

Pl. 53. $f .1$, 2. Linnean Society's Cabinet.

18. Cardium ringens. C. testa rotunda, ventricosa, alba; marginis dentibus profundis, anterioris roseis. Linn. Gmel, p. 3254.

Shell round, ventricose, white ; margin deeply toothed, and rosy, on the fore part.

Testa rotundata, longitudinaliter costata, margine antico profunde serrata, hiante. Brug. Encyc. Meth. Hist. Nat. 6. p. 225.

List. Conch. pl. 330. f. 167. Petiver Mus. p. 36. $n^{0} .836$. Knorr Vergn. 4. pl. 14. f. 3. Favanne Conch. pl. 52. f. F. Chem. Conch. 6. pl. 16. f. 170. Encyclop. Method. pl. 296. f. 3.

A strong shell, with the eight anterior ribs deeply cut like the teeth of a saw; the colour is white, except a rosy blush on the teeth, and, sometimes, on the apex of the shell. The inside is white, with a tint of pale rose colour on the anterior margin; there are four teeth in each valve; two primary teeth, the largest of which is 
erect, and somewhat incurvated, and two lateral teeth, of which one is more remote than the other.

Inhabits the coasts of Guinea, according to Petiver, and was found by Adanson, near the mouth of the Niger.

\section{PROMINENT COCKLE.}

19. Cardium ventricosum. C. testa subcordata, ventricosa, costis angulatis, postice transversim sulcatis, ano ovato, plano. Brug. Encyc. Meth. Hist. Nat. 6. p. 228.

Shell somewhat heart-shaped, ventricose, ribs angular, transversely grooved behind; below the beak, oval and plain.

List. Conch. pl. 328. f. 165. Born Test. pl. 3. f. 5. Encyclop. Method. pl. 299. f. 1.

This shell is very properly distinguished, by Bruguiere, from the following, with which it has hitherto been confounded. It is never so long in proportion to its breadth, as the $C$. magnum, and it grows even to a larger size. It has about thirty-three longitudinal ribs, the seven anterior of which, are flat and imbricated, the twenty-one following are convex, and round, on one side, and angular on the other; the five last, or posterior ribs, are large, convex, but little raised, and without the scaly striæ which cross the others. The margin is crenated; the shell is of a ferruginous colour spotted with brown, and sometimes banded with the same. The inside is reddish at the edges, and near the summit.

Inhabits, according to Lister, the coast of Campeachy. Bruguiere says it is rare in collections, and adds, that he owes to Lamarck the opportunity of describing the shell. 
GREAT COCKLE.

$P l$. 53. $f$. 3. Mr. Jennings.

20. Cardium magnum. C. testa oblonga, costis angulatis, latere serratis.

Linn. Syst. Nat. ed. 12. p. 1123. Linn. Gmel. p. 3250.

Shell oblong, with angular ribs, serrated on the side.

Cardium elongatum. C. testa oblonga, subaquilatera, costis 40 longitudinalibus, utrinque crenato-striatis, posticis striis retrorsum imbricatis. Brug. Encyc. Meth. Hist. Nat. 6. p. 228.

List. Conch. pl. 331. f. 168. Seba Mus. 3. pl. 86. f. 2. Born Test. pl. 3.

f. 6, 7. Chem. Conch. 6. pl. 17. f. 179. Encyclop. Method. pl. 297.

f. 3. Favanne Conch. pl. 52. f. F. Martin Univ. Conch. 2. pl. 80.

This is an oblong, oval shell, with forty longitudinal ribs, according to Bruguiere, but our specimens have only thirty-four. It grows to a very large size, some having been found six inches long and of other dimensions in proportion; the anterior ribs are serrated, the middle ones flattish at top, and the posterior ribs imbricated; the ground colour of the shell is white, with spots, or stains, of yellow, orange, brown, or purple. The inside is white, with a yellow mark reaching from the apex towards the middle of the shell; some are quite white within.

Inhabits the American ocean, and is common on the coasts of Jamaica, and other West India islands. 
20. Cardium lavigatum. C. testa obovata, striis obsoletis longitudinalibus. Linn. Syst. Nat.ed.12. p. 1123. Linn. Gmel. 3251. Shell obovate, with obsolete longitudinal striæ.

List. Anim. Angl. pl. 5. f. 32. - Conch. pl. 332. f. 169. Petiver

Gaz. pl. 93. f. 10. Penn. Brit. Zool. 4. pl. 51. f. 40. Da Costa Brit. Conch. pl. 13. f. 6. Pult. in Hutch. Dorset. pl. 7. f. 6. Donov. Brit. Shells, pl. 54. Mont. Test.Brit. p. 80. Linn. Trans. 8. p. 65. B. Chem. Conch. 6. pl. 18. f. 185, 186.

A strong, smooth, yellowish-white shell, obsoletely ribbed longitudinally, and covered, when recent, with a dark green epidermis : the inside is white, with a crenated margin; length two inches and a quarter; breadth nearly an inch. Young shells are very smooth, and sometimes variegated with rose colour.

Inhabits the coasts of Great Britain.

B. Figure 2. pl. 54. is a variety of our C. lavigatum, of a longer shape, ribbed in the same manner, and prettily mottled with yellow. It inhabits the Indian seas, and is figured by Chemnitz. It is distinguished by Bruguiere, under the name of $\boldsymbol{C}$. biradiatum. Our specimen is not rayed within-side. 


\section{CITRON COCKLE.}

Pl. 54. $f$. 3. Linnean Society's Cabinet.

21. Cardium citrinum. C. testa obovata, lavi, striis obsoletis, margine interiore serrato. Linn. Syst. Nat. ed. 12. p. 1123. Linn. Gmel. p. 3251. C. serratum.

Shell obovate, smooth, with obsolete striæ; margin serrated within. Gualt. Test. pl. 82. f. A. Chem. Conch. pl. 18. f. 189.

A thin, smooth, convex, yellowish shell, with faint longitudinal striæ, sometimes not to be perceived without the help of a lens; the anterior margin is strongly stained of an orange colour. The inside is white and orange, and the margin is crenated.

Inhabits the Mediterranean, the Indian ocean, the coast of South America, and the shores of the West India islands.

It is constituted a distinct species from the C. lavigatum, by Linnæus, under the name of $C$. serratum, and occurs in Chemnitz, and the Linnæan Society's Cabinet, under the more appropriate title of $\boldsymbol{C}$. citrinum.

\section{OBLONG COCKLE.}

\section{Pl. 55. f. 1. Linnean Society's Cabinet.}

22. Cardium oblongum. C. testa flavicante, oblonga, turgida, costata, anterius glabra, cordata, margine crenata. Linn Gmel.p. 3254.

Shell yellowish, oblong, turgid, ribbed, smooth before, heart-shaped, margin crenated.

Chem. Conch. 6. pl. 19. f. 190. Born Test. pl. 3. f. 8. Favanne Conch. pl. 53. f. $L$.

This shell is described, by Bruguiere, under the name 
of $\boldsymbol{C}$. serratum, together with our British C. lavigatum, which he considers as the same species; that they are distinct, however, will be evident on comparison, as the C. oblongum is longer in proportion to its breadth, and is more conspicuously ribbed. It has thirty ribs, is of a uniform yellowish, or rust colour; and is about three inches long, and nearly two inches and a half broad.

Inhabits the Mediterranean, and warmer climates, but is never found in the British seas.

YELLOW COCKLE.

23. Cardium flavum. C. testa subovata, sulcata, latere anteriore scabro, posteriore dentato. Linn. Syst. Nat. ed. 12. p.1123. Linn. Gmel. p. 3251.

Shell somewhat oval, grooved; the anterior margin rough, the posterior toothed.

Schröt. Einl. in Conch. 2. pl. \%. f. 11. a. b.

The C. Alavum, according to the description of Schröter, is of an oblong-oval shape, with twenty-seven ribs, five or six of which, on the anterior part of the shell, are spinous, and twelve or thirteen, on the posterior side, are tuberculated; the intermediate ribs are smooth, and rounded. The margin is crenated, and the valves close every where, except before, where they are a little open. The apex, and anterior part of the shell, are white, the rest is of a sulphur yellow colour; the inside is white, except under the apex, which is reddish yellow.

Inhabits the coast of Coromandel, near Tranquebar.

M. Schröter observes, that the yellow colour of this shell is very superficial, since those specimens which 
have not been taken at sea, but have been for some time lying on the shore, exposed to the sun, are quite white.

\section{BANDED COCKLE.}

Pl. 55. $f$. 2, 3. Linnean Society's Cabinet.

24. Cardium rusticum. C. testa antiquata, costis viginti remotis, interstitiis rugosis. Linn. Syst. Nat. ed. 12. p. 1124. Linn. Gmel. p. 3252.

Shell antiquated, with twenty remote ribs, rugged between.

Rugenf. Conch. 1. pl. 12. f. 77, 78. Chem. Conch. 6. pl. 19. f. $19 \%$.

This is a variegated shell, with light bands on a rich brown ground; the bands are sometimes quite white, and sometimes yellowish, brownish, or tending to blue; the ribs are strong, and generally twenty in number, never more than twenty-two. It resembles the common cockle, but the ribs are more convex and distinct, and the grooves are deeper, and rugged. The inside is white, with a crenated margin.

Inhabits the European seas, particularly the Mediterranean. 
COMMON COCKLE.

$P l$ 55. $f .4$.

25. Cardium edule. C. testa antiquata, costis viginti sex, obsolete recurvato-imbricatis. Linn. Syst. Nat. ed.12. p.1124. Linn. Gmel. p. 3252.

Shell antiquated; ribs twenty-six, with obsolete recurved scales.

List. Anim. Angl. pl. 5. f. 34. - Conch. pl. 334. f. 171. Gualt. Test. pl. 71. f. F. Knorr Vergn.6. pl. 8. f. 4. Penn. Brit. Zool. 4. pl. 50. f. 41. Da Costa Brit. Conch. pl. 11.f. 1. Chem. Conch. 6. pl. 19. f. 194. Encyclop. Method. pl. 300. f. 5. Pult. in Hutch. Dorset. pl. 11. f. 1. Donov. Brit. Shells, pl. 124. Mont. Test. Brit. p. 76. Linn. Trans. 8. p. 66.

This well-known shell is of a yellowish-white colour, with from twenty-three to twenty-six flattish ribs; some specimens have equal sides, and others are more or less elongated at the anterior end. The inside is white, and the margin is dentated. It is commonly about the size of a walnut; but Dr. Maton mentions a variety, much larger, from the coast of Essex, called the Ross cockle.

This is a very common species on the sandy shores of Great Britain and Ireland, where it lies buried a little below the surface. Great abundance of the shells are collected, and regularly brought to London, from spring to autumn, for the sake of the fish, which are regarded as a wholesome and agreeable nourishment. Those which come from Selsea, near Chichester, in Sussex, were considered the best in the kingdom. Prodigious quantities of these shell-fish are also consumed in Holland, where their cheapness recommends them to the common people, as a principal article of food during winter.

Donovan has figured a prolonged variety, under the name of $C$. rusticum. See British Shells, pl. 124. f. 2. 


\section{ICELAND COCKLE.}

26. Cardium Icelandicum. C. testa sulcata, costis ad triginta sex, triquetris, lavibus. Linn. Gmel. p. 3252.

Shell grooved, with about thirty-six smooth, triangular ribs.

Testa gibba, longitudinaliter sulcata, costis subtriquetris, acutis, ano obsolete cordato. Brug. Encyc. Meth. Hist. Nat. 6. p. 222.

Chem. Conch. 6. pl. 19. f. 195, 196. Encyclop. Method. pl. 300. f. 8.

A strong shell, of a whitish, or yellowish-brown colour, with from thirty to thirty-six triangular ribs; the grooves are deep, and ridged transversely, especially towards the external edges; the inside is grooved, with a crenated margin. Length two inches; breadth about the same.

Inhabits the coast of Iceland, and was discovered by Chemnitz.

\section{GREENLAND COCKLE.}

27. Cardium Grœnlandicum. C. testa antiquata, glabra, tenui, murina, lineis angulatis ferrugineis picta; margine glabra, striis longitudinalibus obsoletis. Linn. Gmel. p. 3252.

Shell antiquated, smooth, thin, and mouse-coloured, with angular ferruginous lines; margin smooth, striæ longitudinal, and obsolete. Testa cordata, lavi, grisea, decussata, striis lateralibus obsoletis. Brug.

Encyc. Meth. Hist. Nat. 6. p. 222.

Chem. Conch. 6. pl. 19. f. 198. Encyclop. Method. pl. 300. f. 7.

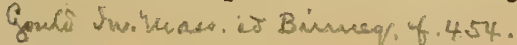

This species, as Chemnitz observes, has externally the appearance of a Venus, and might be taken for a shell of that genus, but for the hinge, which has four teeth, the same as other cockles; but the two primary teeth are very small. The surface is smooth, and marked with very fine, distant, longitudinal strix, diverging 
from the apex to the margin; it is also striated transversely, except towards the lateral edges. It is externally of a mouse grey, with ferruginous zig-zag lines; within, it is flesh-coloured, with a tinge of carnation. Length an inch and a half; breadth rather more.

Inhabits the coast of Greenland.

Chemnitz appears to be the first describer of this, as well as the preceding species. Gmelin might have spared his question, an mera edulis varietas? since it bears not the slightest resemblance to the common cockle.

\section{EQUAL-SIDED COCKLE.}

28. Cardium regulare. C. testa ovata, aquilatera, costis longitudinalibus convexis, notatis lunulis transversis elevatis, antice lamellosis. Brug. Encyc. Meth. Hist. Nat. 6. p. 227.

Shell oval, equilateral, with convex longitudinal ribs, and transverse raised rings; the fore part lamellated.

A white shell, sometimes tinged with yellow round the edges, and within near the summit; it has thirty, or thirty-one, longitudinal ribs, with many smaller ones cutting the others transversely in the middle of the valves, and obliquely on the sides. Length two inches; breadth an inch and three quarters.

Inhabits the coast of the West India Islands.

This species is described only by Bruguiere, who says it is common in the Parisian cabinets. 


\section{PECTINATED COCKLE.}

29. Cardium pectinatum. C. testa subcordata, pectinata. Linn. Syst. Nat.ed. 12. p. 1124. Linn. Gmel. p. 3253.

Shell somewhat heart-shaped, and pectinated.

Gualt. Test. pl. 75. f. $A$. Murr. Fund. Testac. pl. 2. f. 18.

A white shell, with distant striæ, rough upwards; the cavity under the beaks yellow; margins prominent.

Inhabits the Mediterranean.

\section{EARED COCKLE.}

30. Cardium Auricula. C. testa cordata, subrhombea, costis utrinque viginti quatuor; sulcis subtilissime crenulatis, natibus distantibus. Linn. Gmel. p. 3253. Forsk. Faun. Arab. p. 122. No. 52.

Shell heart-shaped, somewhat rhombic, with twenty-four ribs on each side; the grooves very finely crenated; beaks distinct.

Rugenf. Conch. 2. (ined.) pl. 9.

A white pellucid shell, with a toothed margin. Length two inches and a quarter; breadth one inch and three quarters.

Inhabits the shores of Arabia and Egypt. 


\section{ASIATIC COCKLE.}

31. Cardium Lima. C. testa gibba, costis aculeatis, anterioribus tuberculis membranaceis recurvatis ad latera crenatis, sulcis intermediis granulatis. Linn. Gmel. p. 3253.

Shells gibbous; ribs prickly, those before with recurved membranaceous tubercles; intermediate grooves granulated.

Cardium Asiaticum. C. testa cordata, costis obsoletis, longitudinalibus, punctis serialibus subspinosis, antice lamellosis. Brug. Encyc. Meth. Hist. Nat. 6. p. 224.

Chem. Conch. 6. pl. 15. f. 153, 154.

A thin, yellowish-white shell, with from thirty to forty delicate ribs; the apex and interior of the dentated edges are reddish; it is grooved inside. Length two inches; in the breadth rather less.

Inhabits the Indian ocean, and is a very rare shell.

\section{PAPFR COCKLE.}

Pl. 55. f. 5. Mrs. Mawe.

32. Cardium papyraceum. C. testa pellucida, cinerea, striis longitudinalibus tenuibus. Linn. Gmel. p. 3254.

Shell pellucid, and ash-coloured, with thin longitudinal strix.

Chem. Conch. 6. pl. 18. f. 184. Encyclop. Method. pl. 293. f. 2.

A very thin, brittle shell, of a whitish, or ash colour, finely and closely ribbed longitudinally; the margins of the valves are finely toothed; the summits are sometimes marked with purple, and the inside spotted with the same; the hinge is like the other species of the genus. Length an inch and three quarters; breadth nearly the same.

Inhabits the Indian ocean, and is found on the shores of New Holland. 
RIBBED COCKLE.

Pl. 56. f. 1. Dr. Соомв .

33. Cardium costatum. C. testa gibba, aquivalvi, costis elevatis, carinatis, concavis, membranaceis. Linn. Syst. Nat.ed.12. p. 1121.

Shell gibbous, of equal valves, with high, keeled, concave, membranaceous ribs.

List. Conch. pl. 327. f. 164. Rumph. Mus.pl, 48. f. 6. Gualt. Test. pl. 72. f. D. D'Argenville Conch. pl. 26. f. A. Favanne Conch. pl. 52. f. B. Adans. Conch. pl. 18. f. 2. Knorv Vergn. 1. pl. 28. f. 2. Chem. Conch. 6. pl. 15. f. 151, 152. Encyclop. Method. pl. 293. f. 1. $a-c$.

A large, suborbicular shell, of a milk-white colour, except between the middle ribs, where it passes from light tawny to chocolate brown; it is extremely thin, brittle, and transparent, when young, but becomes thick, strong, and opaque in old age; there are eighteen very large channels, proceeding from the apex to the circumference of the shell, forming so many high, sharp-edged, ribs. The inside is grooved to correspond with the ridges on the surface; the teeth are large and strong; the middle is long and pointed. The largest specimens measure four inches in length, and four inches and a half in breadth.

Inhabits the coast of Guinea, and the sandy shores of Senegal, but is very rarely to be obtained perfect. M. Adanson, who has particularly described this shell, says that single valves only are thrown on the shore; the animal, living in very deep water, cannot be dredged up alive, and therefore very few cabinets possess this shell entire, or with similar valves. 
GAPING COCKLE.

\section{Pl. 56. f. 2. Mrs. MAWE.}

44. Cardium apertum. C. testa subcordata, tenuissima, alba, costis obsoletis oarinatis. Gronov. Zooph. pl. 18. f. 5.

Shell somewhat heart-shaped, with very thin, white ribs, obsoletely carinated.

Testa subcordata, tenuissima, alba, antice producta, hiante, costis obsoletis, acutis, muticis. Brug. Encyclop. Method. Hist. Nat. 6. pl. 226.

Chem. Conch. 6. pl. 18. f. 181-183. Encyclop. Method. pl. 296. f. 5. a. $b$.

A very thin, fragile, whitish shell, with numerous worn ribs; round at one end, and produced at the other, where it gapes considerably; the margin is dentated. Inside white, stained with purple towards the middle, and at the open end of the shell; hinge with four teeth in each valve, two at the beak, as in other species, and two lateral, oblong, like those in the genus Mactra. Length an inch and a quarter; breadth an inch and a half; but it grows to a larger size.

Inhabits the seas of Asia and South America; Gronovius says, the coasts of Jamaica. It is a very rare shell, and is referred by Gmelin to $C$. virgineum of Linnæus; but that shell is a doubtful species, certainly not the $C$. apertum, but perhaps the $C$. glaucum of Bruguiere. 
SOLEN COCKLE.

$P l$.56. f. 3. Dr. Соомве.

35. Cardium soleniforme. C. testa transverse ovata, fragili, longitudinaliter striata, utrinque muricata, antice hians. Brug. Encyc. Meth. Hist. Nat. 6. p. 235.

Shell transversely oval, brittle, longitudinally striated; both valves prickly, gaping before.

Solen bullatus. Linn. Syst. Nat. ed.12. p. 1115. Linn. Gmel.p. 3226.

List. Conch. pl. 342. f. 179. Gualt. pl. 85. f. H. Chem. Conch. 6. pl. 6. f. 49, 50. Encyclop. Method. pl. 296. f. 6. a.b.

A thin, oblong-oval shell, rough, with minute spines at each end, produced, and gaping before; the ribs are numerous, rather distant on the gaping end, which is strongly serrated at the margin; the colour is white, stained, almost entirely, with purple. Inside smooth, glossy, and marked with purple and pink; the hinge has three teeth in each valve, one central, and two lateral.

Inhabits the South American ocean, and the coasts of Jamaica, St. Domingo, and Martinique.

\section{PECTEN COCKLE.}

36. Cardium pecteniforme. C. testa rotundata, complanata, costis triangulis, lateralibus muricatis. Born Test. pl. 3. f. 10.

Shell round, flattish; ribs triangular; sides spiny.

Gualt. Conch. pl. 71. f. H. Chem. Conch. pl. 17. f. 180.

An orbicular shell, white, spotted with blackish brown, deeply grooved, and furnished with rough scaly longitudinal ribs; the margin is crenated; the inside 
white, with longitudinal grooves. Length an inch; breadth the same.

Country unknown.

First described by Baron Born.

\section{DONAX COCKLE.}

37. Cardium donaciforme. C. testa subcordata, longitudinaliter sulcata, antice truncata, natibus cancellatis. Brug. Encyc. Meth. Hist.Nat. 6. p. 214.

Shell somewhat heart-shaped, longitudinally grooved, truncated before; beaks channelled.

Chem. Conch. 6. pl. 16. f. 165. Encyclop. Method.pl. 296. f. 2. Scliröt. Einl. in Conch. 3. pl. \%. f. 14.

This species has the form of a Donax; it is broader than long, flat before, and nearly of a triangular shape; the longitudinal ribs are flat, and separated by shallow grooves, like striæ; the anterior end is heart-shaped; it is of a dull white colour, tending to yellow, and marked with brown spots, and streaks; the lateral teeth in one valve are sharp-pointed, in the other obtuse.

Inhabits the Indian ocean.

\section{FURBELOWED COCKLE.}

Pl. 56.f. 4, 5. Mr. Jennings.

38. Cardium fimbriatum. C. testa subcordata, costis utrinque viginti quatuor, margine fimbriato.

Shell somewhat heart-shaped; ribs on both valves, twenty-four; margin fringed.

This new and singular species is about the size of the common cockle, with regular longitudinal ribs, ter- 
minating, at the margin of the shell, in a wide fringe, or furbelow, which is so strongly characteristic, that the species can never be mistaken. The other parts of the shell are smooth, and, in colour and appearance, much like the $C$. edule. The inside is white, the hinge strong, and the lateral teeth prominent.

Country unknown.

This curious shell is one, among many rarities, in the cabinet of Mr. Jennings.

\section{JANUS COCKLE.}

\section{Pl. 5\%. f. 1. Dr. СоомвE.}

39. Cardium Æolicum. C. testa crassa, striis anterioribus longitudina-

libus, posterioribus transversis. Linn. Gmel. p. 3254.

Shell thick; anterior striæe longitudinal, posterior transverse.

Bionan. Recr. f. 91. - Mus. Kirch. 2. f. 89. List. Conch. pl. 314. f. 150. Knorr Vergn. 5. pl. 26. f. 1, 2. and 27. f. 3. Chem. Conch.

6. pl. 18. f. 187, 183. Encyclop. Method. pl. 296. f. 4.

A very convex, irregular shell, somewhat truncated before, of a white colour, variegated with brown and reddish spots and stains. This shell presents three distinct faces; the anterior, which is the smallest, is smooth, protuberant, and shining; the second extends to the middle of the shell, and is striated, or closely and finely ribbed longitudinally ; the third, or posterior face, occupies the rest of the surface, and is marked transversely, and obliquely, with distant raised strix, which feel rough, when rubbed downwards from the apex. The inside is white in the middle, yellowish near the summit, and somewhat flesh-coloured at the 
margin, which is serrated : the hinge resembles the other species of this genus.

Inhabits the Indian seas, and the coasts of China.

\section{ROUGH COCKLE.}

Pl. 57. $f$. 2, 3. Linnean Society's Cabinet.

40. Cardium rigidum. C. testa subcordata, anterius subtruncata, costis rugosis, prominulis.

Shell somewhat heart-shaped, rather truncated before; ribs prominent, and wrinkled.

A small shell, of a whitish colour, with longitudinal grooves, and ribs; the latter covered with a strong; thick, wrinkled epidermis, which adheres very firmly to the shell, but which, when removed, leaves the ribs flattish, and smooth. Inside white; teeth of the hinge strong.

Country unknown.

\section{BROAD COCKLE.}

Pl. 57. f. 4, 5. Linnean Socrety's Cabinet.

41. Cardium latum. C. testa lata, incequilatera, intus alba ; costis magnis planis spinulosis. Linn. Gmel. p. 3254.

Shell broad, of unequal sides, within white; the ribs rather flat and spinous.

Tcsta transverse ovata, costis longitudinalibus muricatis, natibus violaceis. Brug. Encyc. Meth. Hist. Nat. 6. p. 234.

Knorr Vergn. 6. pl. 7. f. 6. Born Test. pl. 3. f. 2. Chem. Conch. 6. pl. 19. f. $192,193$.

A strong shell, of a ferruginous colour, with the shape of a $V$ enus, but the characters of a Cardium; it has flat 
longitudinal ribs, separated by narrow grooves; the margin is crenated. The inside is white, and grooved, and the lateral teeth of the hinge are strong.

Inhabits the Indian ocean, and the Nicobar islands.

The only specimen of this shell in the Linnæan collection is a worn single valve. In its live state, it is described by Chemnitz as of a white colour, spotted and banded with pale yellow, and armed with minute points, which seem hollow, and feel rough when the finger is passed over the shell. Our shell appears to be the same, excepting colour and size, as that of Chemnitz; but Born's specimen differs from both, the hinge in his figure being nearer to the middle of the shell.

\section{FLEXUOUS COCKLE.}

12. Cardium flexuosum. C. testa rotundata, fusca; costis flexuosis, sulcis rugosis. Linn. Gmel. p. 3255.

Shell rounded, brown, ribs flexuous, grooves wrinkled.

List. Conch. pl. 343. f. 180.

An obscure species, about an inch and three quarters long.

\section{DECUSSATED COCKLE.}

43. Cardium cancellatum. C. testa subrubra, tenui, rotundata, decussatim striata. Linn. Gmel. p. 3256.

Shell reddish, thin, rounded, with decussated striæ.

Gualt. Test. pl. 83. f. $B$.

A small species described only by Chemnitz. Not more than half an inch broad. 
RUSTY COCKLE.

44. Cardium rubiginosum. C. testa rubella, inaquilatera; costis convexis, transversim striatis. Linn. Gmel. p. 3256.

Shell reddish, with unequal sides; ribs convex, transversely striated.

Gualt. Test. pl. 83. f. $D$.

A somewhat oval shell, very strongly ribbed, with wide grooves between; margin crenated. Length an inch; breadth an inch and a quarter.

Country unknown.

\section{WHITISH COCKLE.}

45. Cardium albidum. C. testa incequilatera, costata, subalbida, intus purpurea. Linn. Gmel. p. 3256.

Shell of unequal sides, ribbed, whitish; inside purple.

Gualt. Test. pl. 83. f. $H$.

A very small shell, about a quarter of an inch long, with longitudinal ribs, and a serrated margin. Perhaps the young of a larger shell.

\section{GREENISH COCKLE.}

46. Cardium virescens. C. testa incequilatera, oblonga, costis subtilibus, supra duplicatis. Linn. Gmel. p. 3256.

Shell of unequal sides, oblong, with very fine ribs, doubled above.

Gualt. Test. pl. 84. f. $A$.

A thin, brittle, pellucid shell, of a greenish white colour, sometimes variegated with rosy spots. Inside silvery. Length three quarters of an inch. 
STREAKED COCKLE,

47. Cardium lineatum. C. testa cordata, carinata, anterius oblique truncata, tenui, glaberrima, nivea, aureo striata, margine denticulata. Linn. Gmel.p. 3246.

Shell heart-shaped, keeled; the fore part obliquely truncated, thin, very smooth, white, with gilt strix; margin toothed.

Kämm. Lab. Rudolst. p. 210. No. 2. pl. 12. f. 4.

This shell is introduced by Gmelin, on the authority of Kämmerer.

\section{ROSE COCKLE.}

\section{Pl. 57. f. 6. Linnean Society's Cabinet.}

48. Cardium roseum. C. testa cordata, anterius lineis, posterius striis paulo latioribus, conjunctione cordis figuram amulantibus exarata; hinc convexa, illinc concava. Linn. Gmel. p. 3245.

Shell heart-shaped, with lines on the fore part, and broader striæ behind, forming, by their conjunction, the figure of a heart; one part convex, the other concave.

Argenville Conch.pl. 23. f. D. Chem. Conch. 6. pl. 14. f. 147. Encyclop. Method.pl. 294. f. 2. a. b.

This shell resembles the $C$. Cardissa; but the margin is plain, the valves are more concave, and the shell never grows to so large a size. The concavity is streaked and stained with rose colour, and the convex part is dotted with the same on a white ground.

Inhabits, according to Chemnitz, the coasts of the Nicobar Islands, and the entrance of the Gulf of 'Bengal. It is a very rare species. In the Linnean Collection it is named, by Dr. Solander, C. impressum. 


\section{TRIANGULAR COCKLE.}

\section{Pl. 57. $f$. 7, 8. Linnean Society's Cabinet.}

49. Cardium hemicardium. C. testa cordata, subquadrilatera, valvulis carinatis, natibus distantibus. Linn. Syst. Nat. ed. 12. 1121. Linn. Gmel. p. 3246.

Shell heart-shaped, somewhat four-sided, with keeled valves, beaks distant. Testa cordata, subtrilatera, antice carinata, sulcis longitudinalibus punctatis, ano ovato, plano. Brug. Encyc. Meth. Hist. Nat. 6. p. 211.

Rumph. Mus. pl. 44. f. H. Petiver Aquat. Amboin. pl.17. f. 4. Gualt. Test.pl. 83. f. c. KnorrVergn.6. pl. 3. f. 2. Chem. Conch. pl. 16. f. 159-161. Encyclop. Method. pl. 295. f. 2. b. c.

This is a triangular, heart-shaped shell, of a whitish or yellowish cast on the outside, and white and shining within; there are, in some specimens, near the lateral teeth, two brown oblong spots, which, in others, are not to be seen. The ribs, which are twenty-three or four in number, are rather flat, and smooth; those on the posterior part of the shell are tuberculated; the anterior ribs are plain; the intermediate grooves are wrinkled, and marked with excavated dots. The inside is white, and the margin deeply crenated; the hinge has four teeth, which are large and triangular, except the middle one, which is but half the size of the others.

Inhabits the East Indies. Rumphius says the island of Amboina. 
STRAWBERRY COCKLE.

Pl. 58. f. 1, 2. Dr. Соомве.

50. Cardium Fragum. C. testa subcordata, subangulata; costis notatis lunulis elevatis. Linn. Syst. Nat. ed. 12. p. 1123 . Linn. Gmel. p. 3249.

Shell somewhat heart-shaped, subangular; ribs marked with elevated rings.

List. Conch. pl. 315. f. 152. Petiver Aquat. Amb. pl. 18. f. 21. Rumph. Mus. pl. 44. f. G. Gualt. Test. pl. 83. f. E. Born Test. pl. 3. f. 3, 4. Chem. Conch. 6. pl. 16. f. 166, 167. Encyclop. Method. pl. 295. f. 3. $a-e$.

A whitish, or yellowish shell, formed of three unequal planes; the anterior face is raised in the middle, so as to form an obtuse angle; the two posterior faces are round, and their edges describe the segment of a circle. It has on each valve, about twenty-three convex, longitudinal ribs, eleven of which, on the anterior face, are partly covered with little rough scales, the upper part of the shell being smooth; the scales on the posterior face are farther apart, thicker, and more prominent, but not so numerous as those before; the margins of the valves are crenated; the anterior margin is deeply serrated, and does not shut so close as the rest of the shell ; the summits are conic, slightly oblique, and separated from each other by a thread line. The inside is white, with a yellow, or orange band, extending from the summit to the middle of the cavity; there are five teeth in each valve, two at the beak, two lateral, and one long and conical, just before the ligament; all these teeth are articulated into corresponding cavities in the opposite valve.

Inhabits the Indian seas, and, according to Linnæus, is sometimes found in the American ocean.

VOL. I. 


\section{WHITE STRAWBERRY COCKLE.}

$P l$. 58. f. 3. Mr. StRong.

51. Cardium Unedo. C. testa subcordata, costis lunulis coloratis. Linn. Syst. Nat. ed. 12. p. 1123. Linn. Gmel. p. 3250. Shell somewhat heart-shaped; ribs with coloured rings.

Testa subcordata, antice angulata, prominens, costis lunulis elevatis, coloratis. Brug. Encyc. Meth. Hist. Nat. 6. p. 214.

Bonan. Recreat. Class. 3. f. 375. List. Conch. pl. 135. f. 151. Rumph. Mus. pl. 44. F. Gualt. Test. pl. 83. f. A. Knorr Vergn. 2. pl. 29. f. 2. Rugenf. Conch. pl. 3. f. 25. Da Costa, Elem. of Conch. pl. 6. f. 8. Chem. Conch. 6. pl. 16. f. 168, 169. Encyclop. Method. pl. 295. f. 4 .

A white shell, marked with red rings upon the posterior part, and some of the middle ribs, and shaped like the preceding species. It is much larger than the $\boldsymbol{C}$. Fragum, and is without the close imbricated scales peculiar to that shell; it has thirty longitudinal ribs, with smooth and deep corresponding grooves. In other respects it agrees entirely with the preceding species. Inhabits the Indian ocean, the coast of Amboina, and, according to Davila, sometimes that of Jamaica. 
DIANA HEART COCKLE.

Pl. 58. f. 4, 5. Mr. JENNINGS.

52. Cardium retusum. C. testa cordata, valvulis striatis, crenulatis, subcarinatis; ano lunato cordiformi intruso. Linn. Syst. Nat. ed. 12. p. 1121. Linn. Gmel. p. 3245.

Shell heart-shaped, valves striated, crenated, and somewhat keeled; a lunate, heart-shaped hollow behind the beak.

Testa cordata, umbonibus carinatis, sulcis longitudinalibus punctatis, costis granulatis, ano lunari intruso. Brug. Encyc. Meth. Hist. Nat. 6. p. 210.

Rugenf. Conch. 2. pl. 9. f. 20. Born Mus. pl. 3. f. 1, 2. Chem. Conch. 6. pl. 12. 139-142. Encyclop. Method. pl. 294. f. 3. b-d.

A white, shining shell, sometimes straw-coloured, and occasionally spotted with red. It is marked with about twenty-one longitudinal grooves, formed of minute sunk points, which give the shell the appearance of being striated transversely; the ribs are smooth and convex, the largest behind, and tuberculated. The inside is white, and glossy; the margin is crenated; there are three teeth in one valve, and four in the other; the moon-shaped hollow, behind the beaks, is a remarkable character in this shell. Large specimens measure nearly two inches in length and breadth.

Inhabits the East Indies, the Persian Gulf, and the Red Sea. It is a rare shell, and valuable when marked with red spots. 


\section{SPINY-KEELED HEART COCKLE.}

Pl. 59. $f, 1,2$. Mr. Sowerby.

53. Cardium Cardissa. C. testa cordata, valvulis compressis, dentato carinatis, natibus approximatis. Linn. Syst. Nat. ed. 12. p. 1121. Linn. Gmel. p. 3245.

Shell heart-shaped; valves compressed, toothed on the keel; beaks close together.

Testa cordiformi, utrinque compressa, umbonibus carinatis, natibus incurvis, super impositis. Brug. Encyc. Meth. Hist. Nat. 6. p. 208.

List. Conch. pl. 318. f. 155. Rumph. Mus. pl.43. f. E. Gualt. Test. pl. 84. f. B. C. D. D'Argenville, pl. 23. f. 1. Favanne Conch. pl. 51. f. E. 2. Born. Test. pl. 2. f. 17, 18. Chem. Conch. 6. pl. 14. f. 143, 144. Encyclop. Method.pl. 293. f. 6. a.b.

This is a completely heart-shaped shell, remarkable for its elegant form, and the singular flatness of its valves. It is of a whitish colour, sometimes variegated with milky spots, and sometimes, though more rarely, with pale rose colour. The valves are as thin as paper, and edged with a spiny keel; the anterior face of the shell is concave below, and convex above, with a small heart-shaped depression, just beneath the summit, containing the cardinal ligament. There are about thirteen longitudinal ribs on the anterior side, with their corresponding grooves. The posterior face is uniformly convex, except close to the margin, where the valves insensibly flatten; there are twelve ribs on this side, and as many channels, which are flat, finely striated, and armed, except the four exterior, with minute points, which roughen the shell; there are four teeth in each valve.

Inhabits the Indian ocean, the coast of Coromandel, and the Persian Gulf. 


\section{SMOOTH-KEELED HEART COCKLE.}

$P l$ 59. $f$. 3, 4. Mr. Jennings.

54. Cardium humanum. C. testa cordata, valvulis compressis, carinis lavis, umbonibus approximatis.

Shell heart-shaped, valves compressed, keel smooth, beaks close together. List. Conch. pl. 219. f. $158 . \quad K n o r r$ Vergn. 6. pl. 11. f. 1. Born Test. pl. 2. f. 15, 16. Chem. Conch. 6. pl. 14. f. 145, 146. Encyclop. Method.pl, 294. f. 1.a.b.

This shell has been considered by Linnæus, and some subsequent authors, as a variety only of the preceding; but we are disposed to agree with Chemnitz, who has distinguished it specifically on account of its margin, which is always smooth, and its colour, which generally consists of red spots, disposed in a quincunx order, upon a white ground.

Inhabits the same country as the preceding, but is more rare.

The beautiful shell, from which our figure was coloured, formerly belonged to Dr. G. Fordyce, who refused fifty guineas for it. This shell is now in the possession of Mr. Jennings, to whose liberality the Author is greatly indebted for the use of many rare and valuable specimens.

The C. monstrosum of Chemnitz, 6. pl. 14. f. 140, 150. bears too strongly the character of an accidental difformity to be noticed as distinct, till more have been found of the same shape.

Gmelin's variety $\beta$, of $C$. medium, p. 3246 , must be rerejected; it is the $C$. donaciforme, quite a distinct shell. 
His varieties of $\boldsymbol{C}$. aculeatum are not to be trusted; var. $\delta$ is our $C$. ventricosum. C. ciliatum, p. 3248, is the same as $C$. echinatum. C. virgineum is a doubtful species, as described by Linnæus ; and Gmelin has completely confused it, by referring to the $\boldsymbol{C}$. apertum of Chemnitz, 6 . pl. 18. f. 181. for a variety of the shell. C. trilaterum of Gmelin, p. 3253, is not specific. His C. triste is omitted, as doubtful ; it is not in the last edition of the Systema Nature. C. crassum, p. 3254 , is probably a variety of C. oblongum. C. maculatum, p. 3255, is our C. ventricosum. His C. fluviatile is the C. lavigatum. C. Basiliense is doubtful. C. Gaditanum and $C$. Amboinense belong to the genus Arca. C. squamosum, p. 3256, is a young shell of the $C$. Isocardia. $C$. fasciatum is a variety only of C. rusticum. 


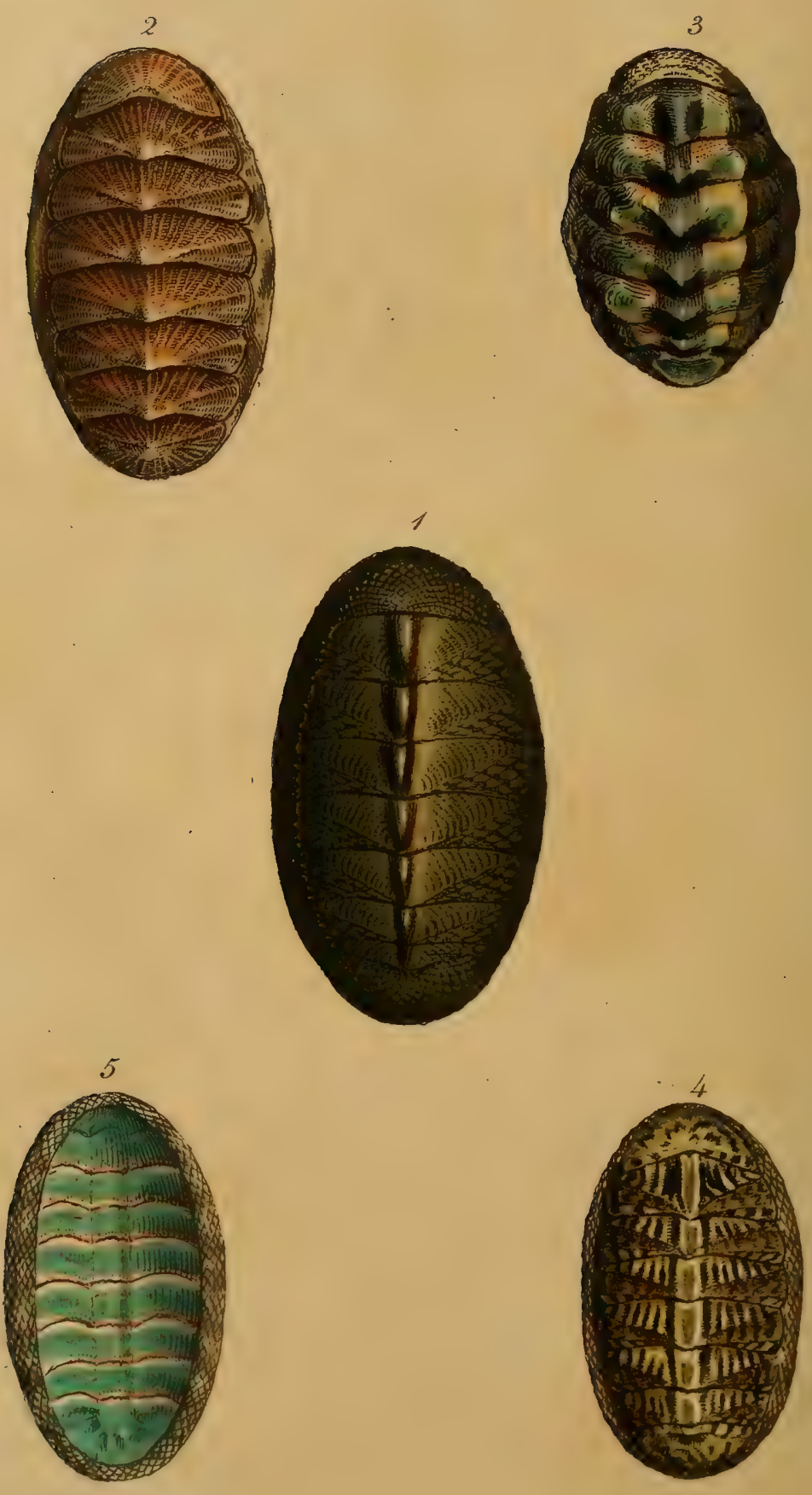


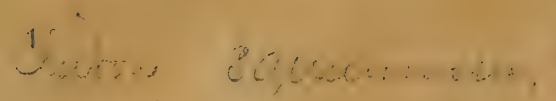

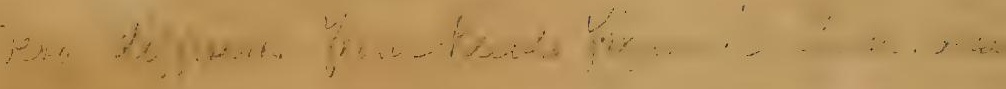

$=2 ; \cos \cdots$

$3 C, v \cos , \quad y$

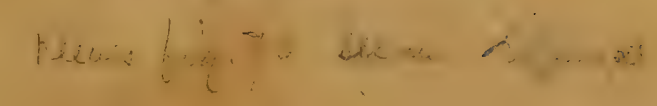

$3 \quad 3 \quad 242,30$ 


CHITOA

PPLQ2。
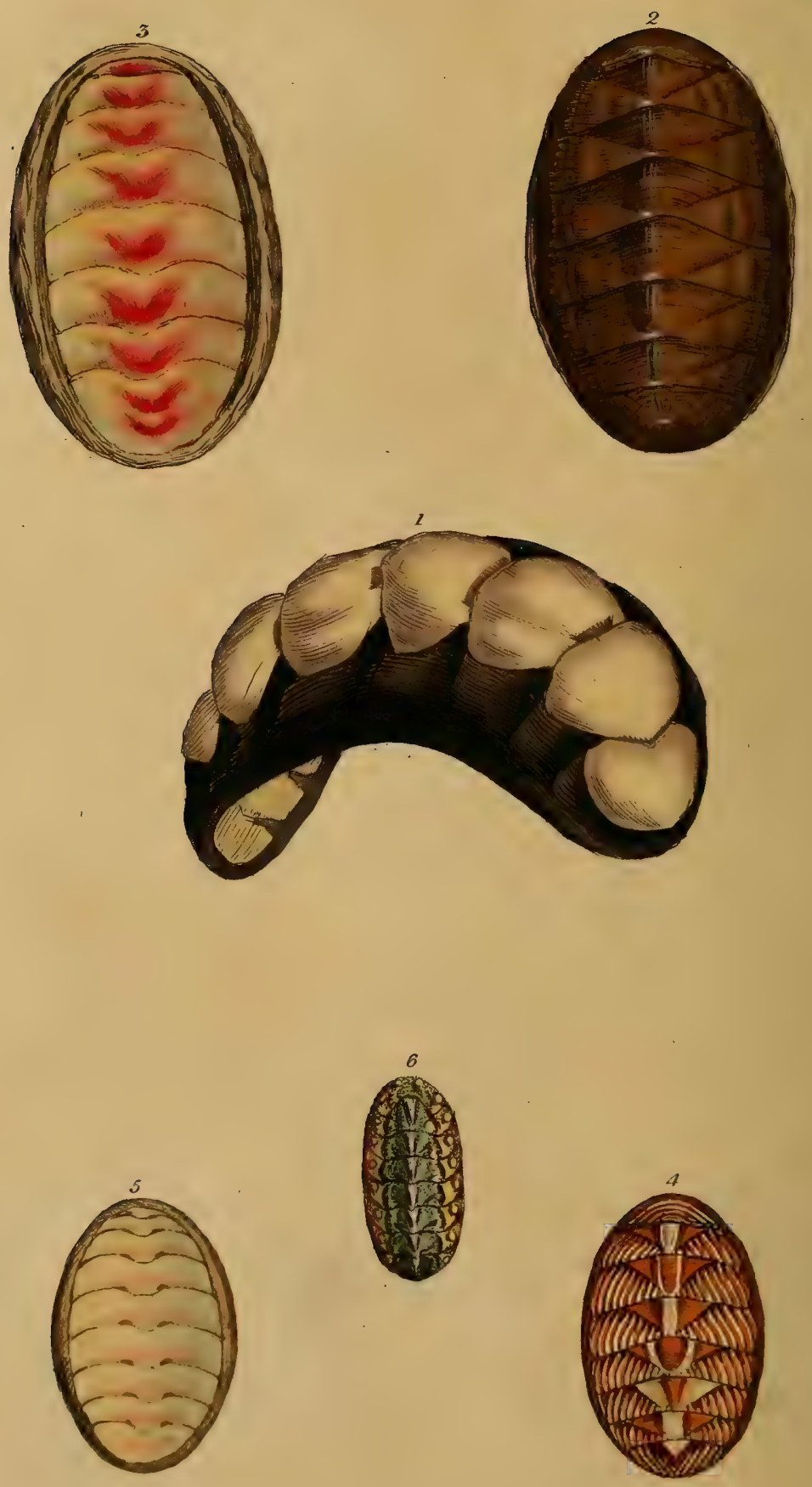
1 Oiling tirnceatir. Wres:

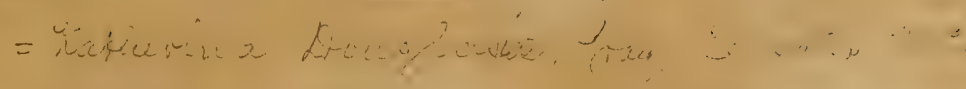

2.3. e vastanesce. Liver.

4.5. C. lineatus, Irvo

$6 \therefore 4+200$, 


istos Ane

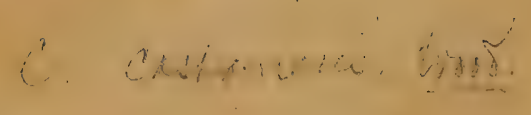

(1. quatiluatas, Viman!

c. cinomero, di.

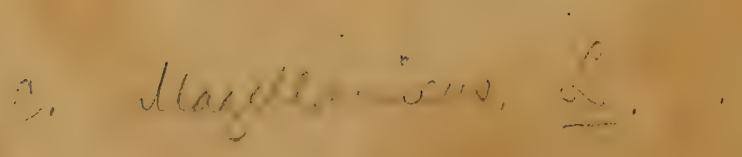



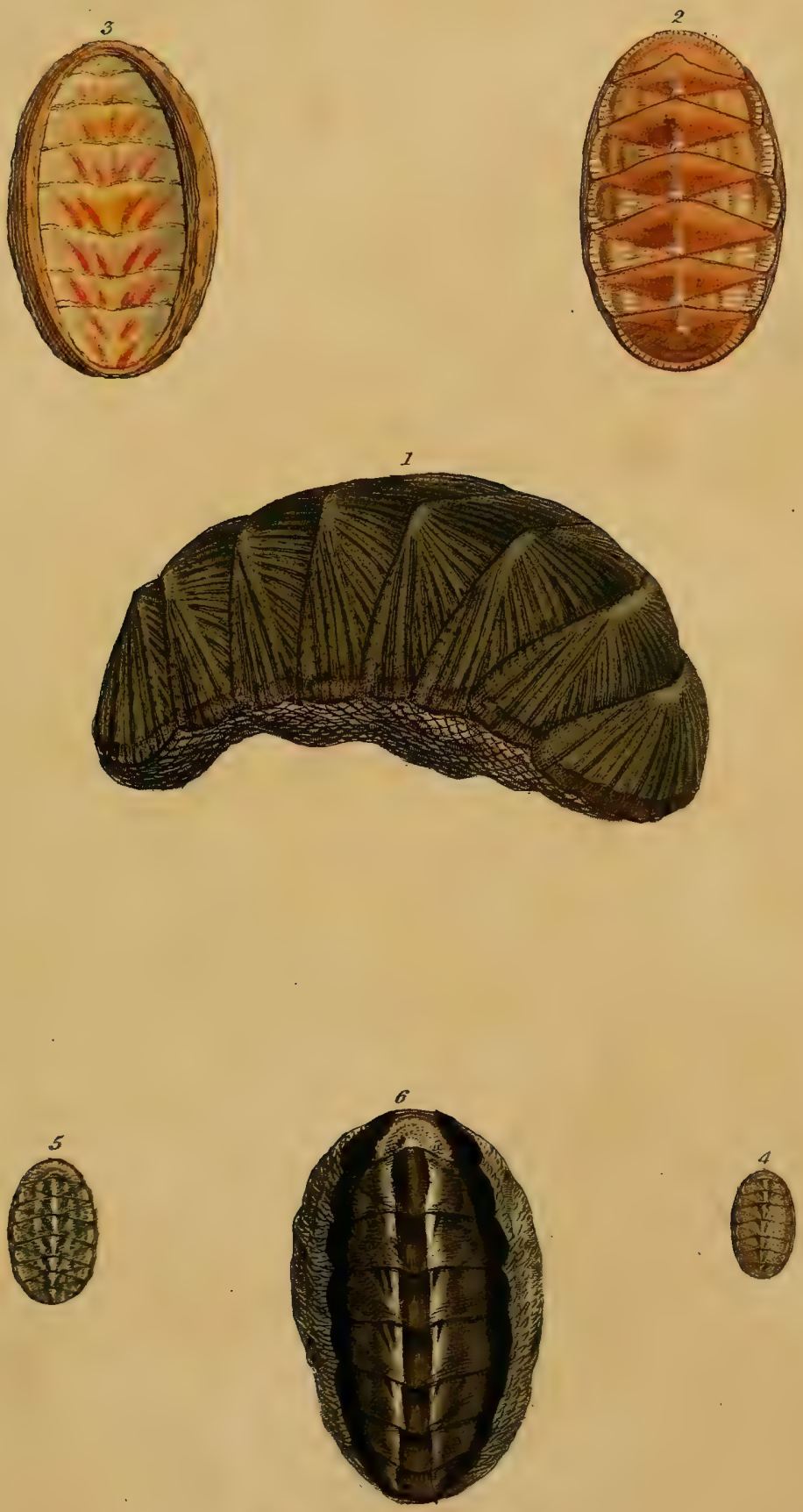



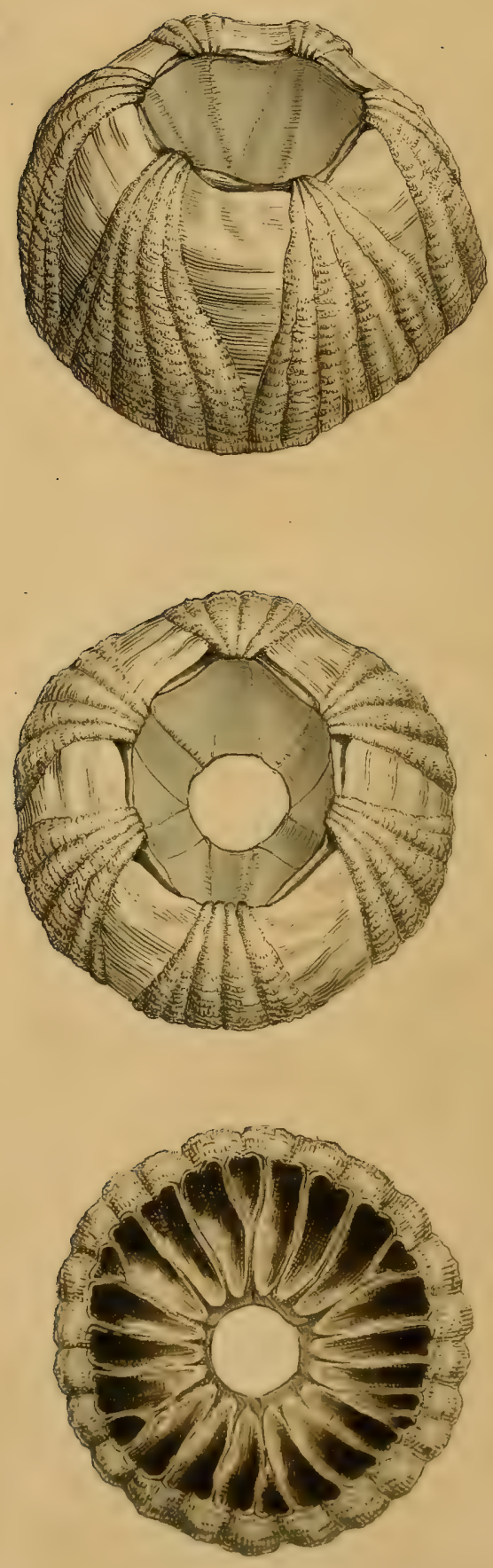




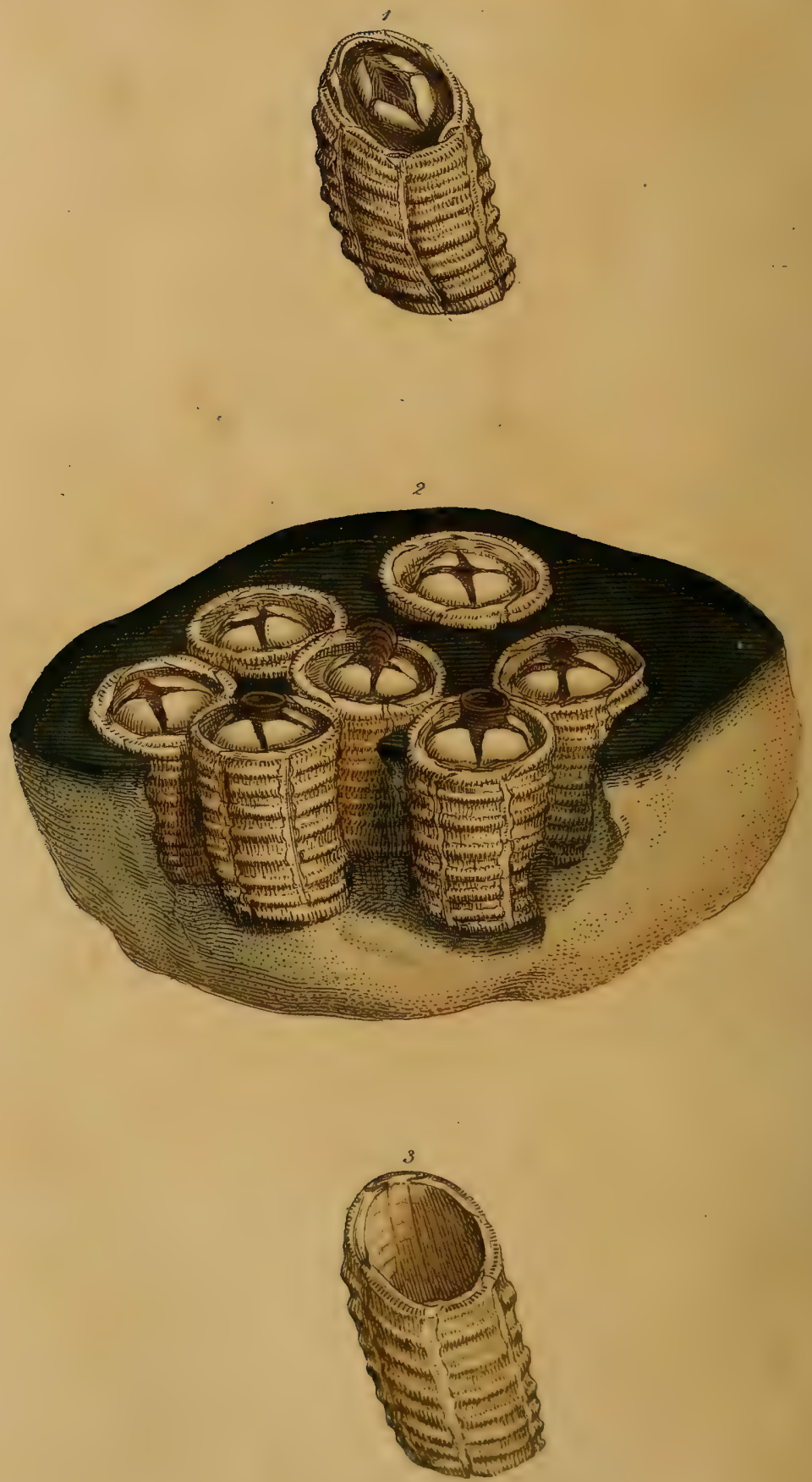





\section{$\mathbb{Z} \mathbb{I} \mathbb{P} \cdot \mathbb{A}$ 舟。}

$\mathbb{P} \mathbb{Z}$ 。5.
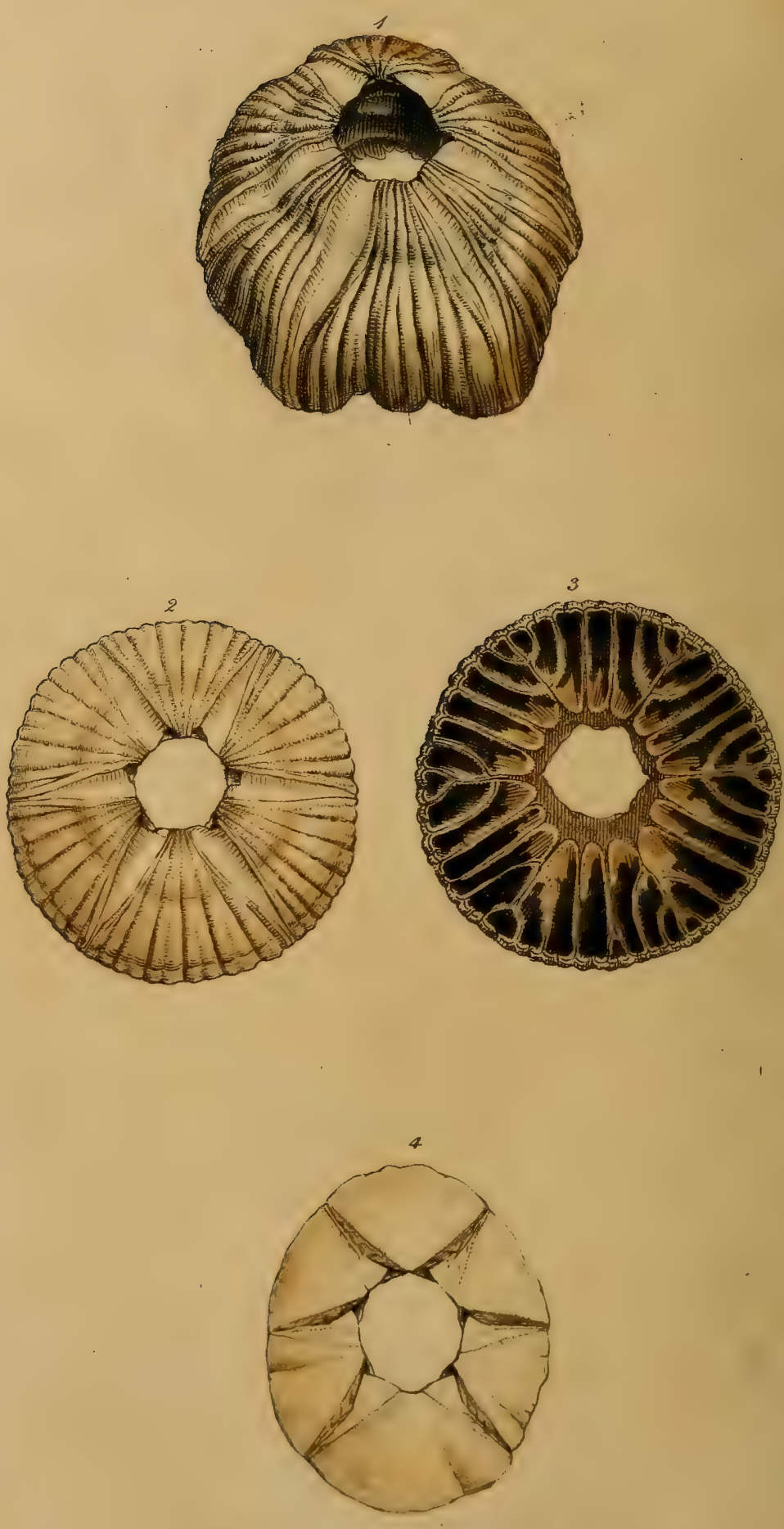


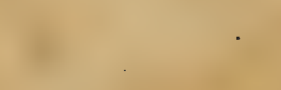




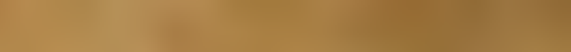





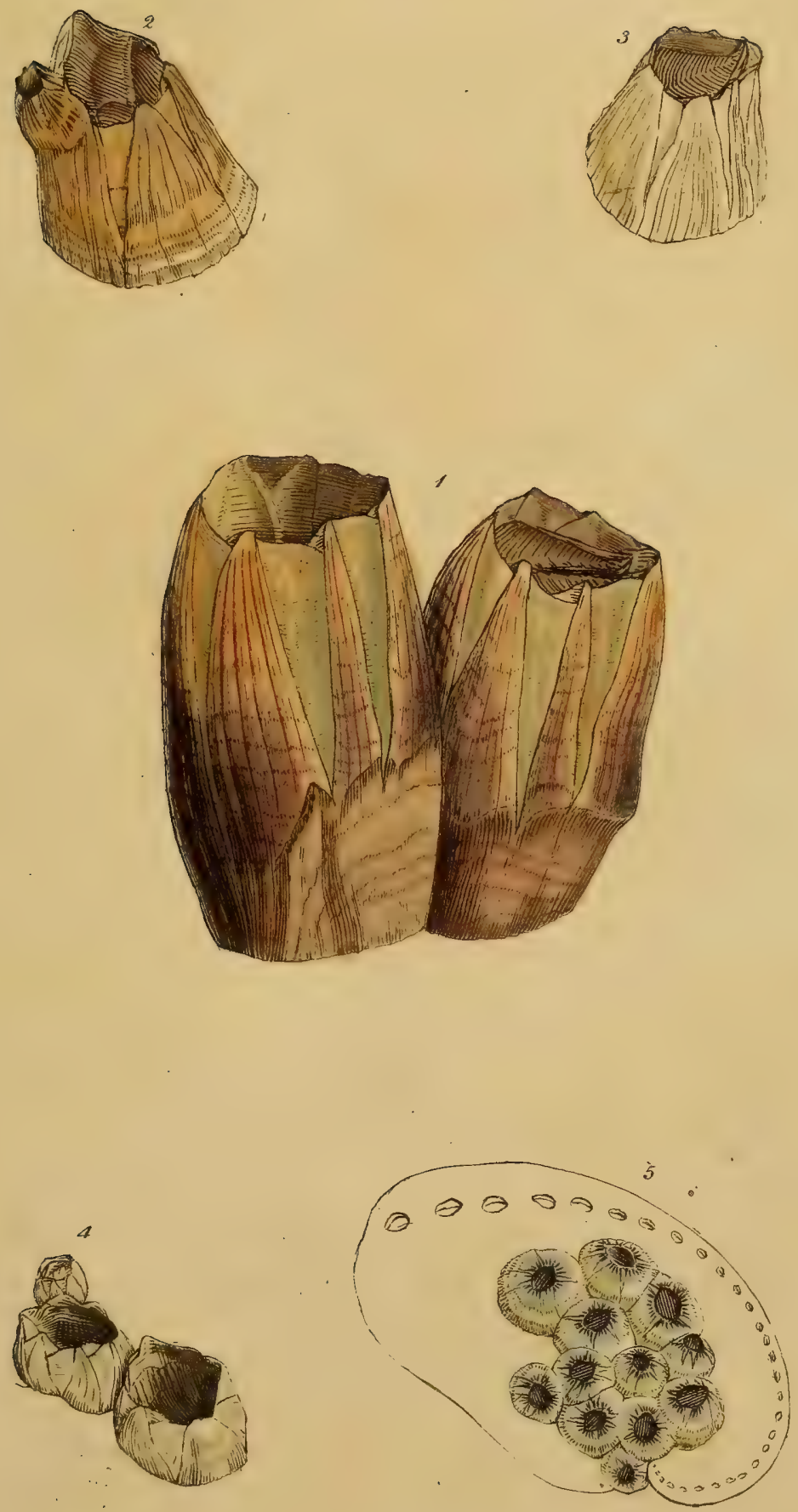




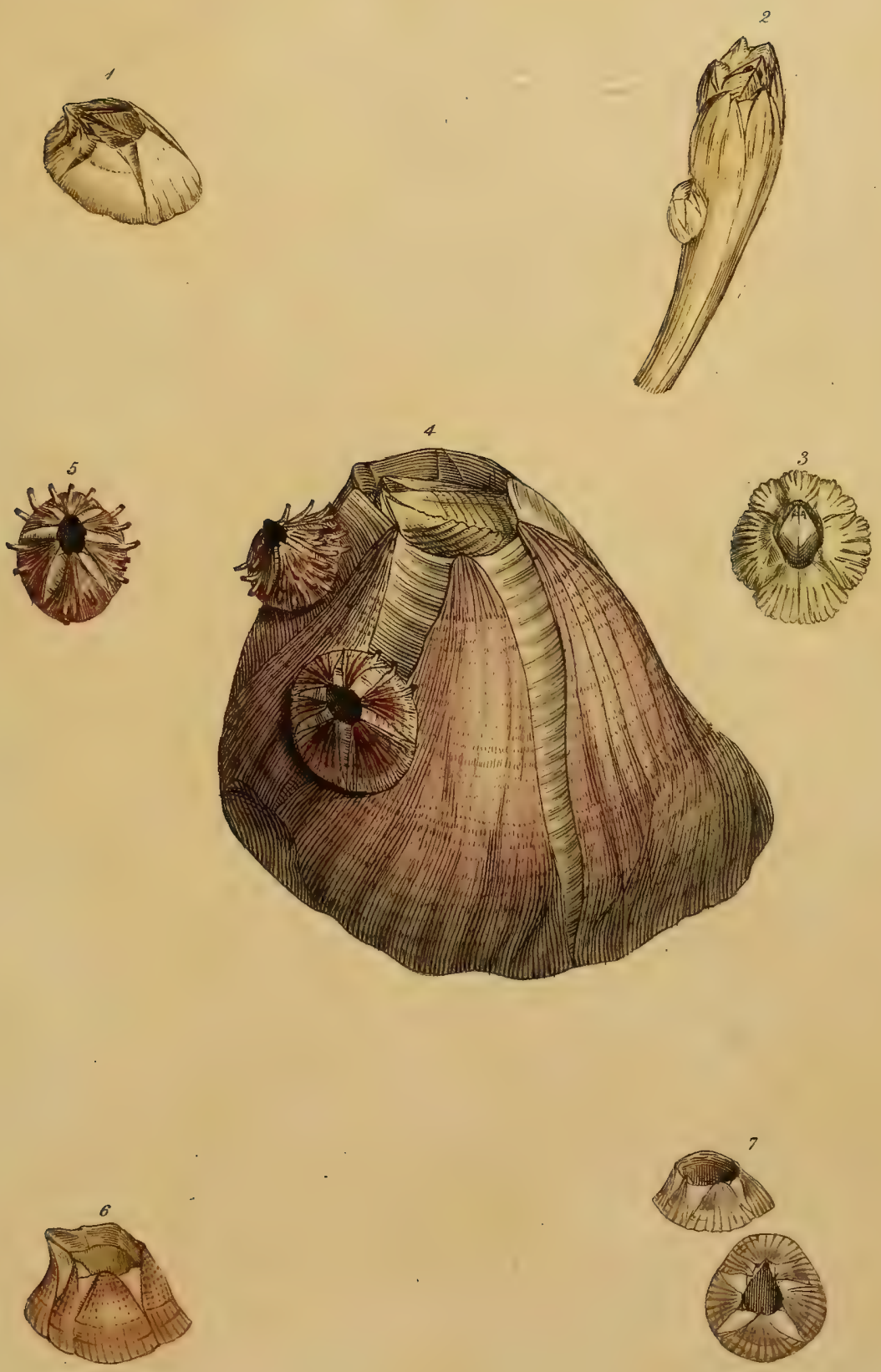



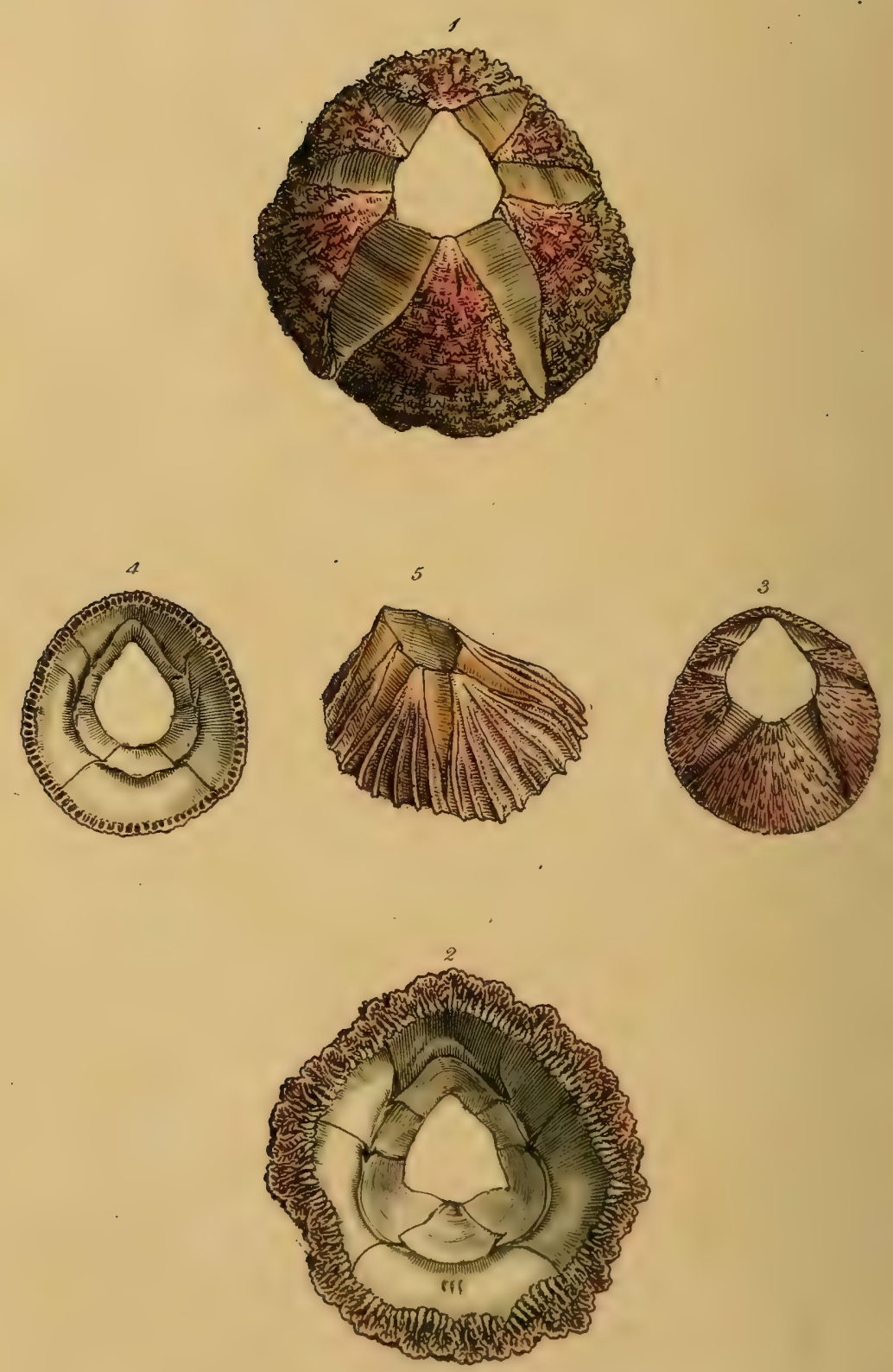




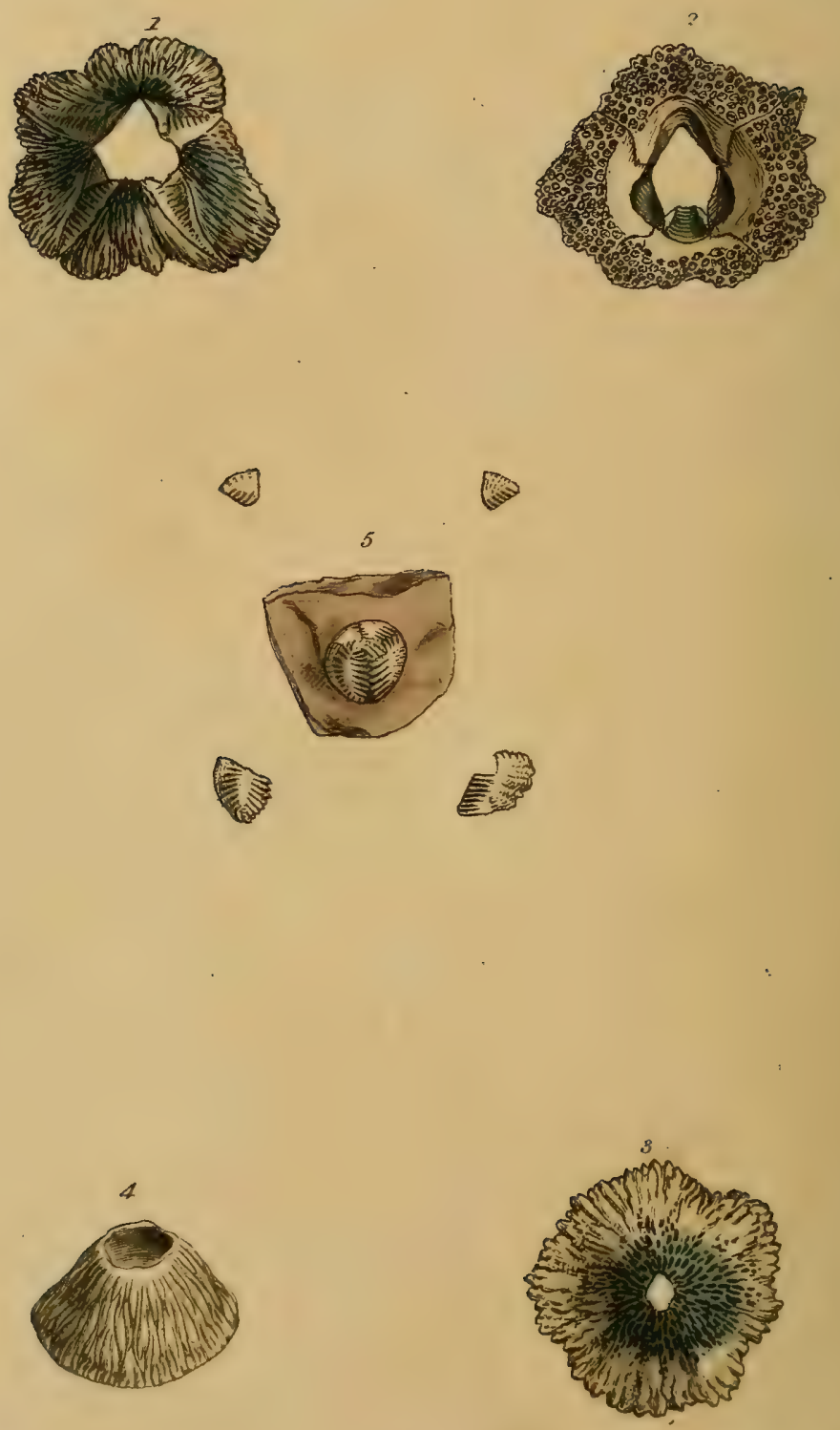



ZTHAPS.

PPILallo.
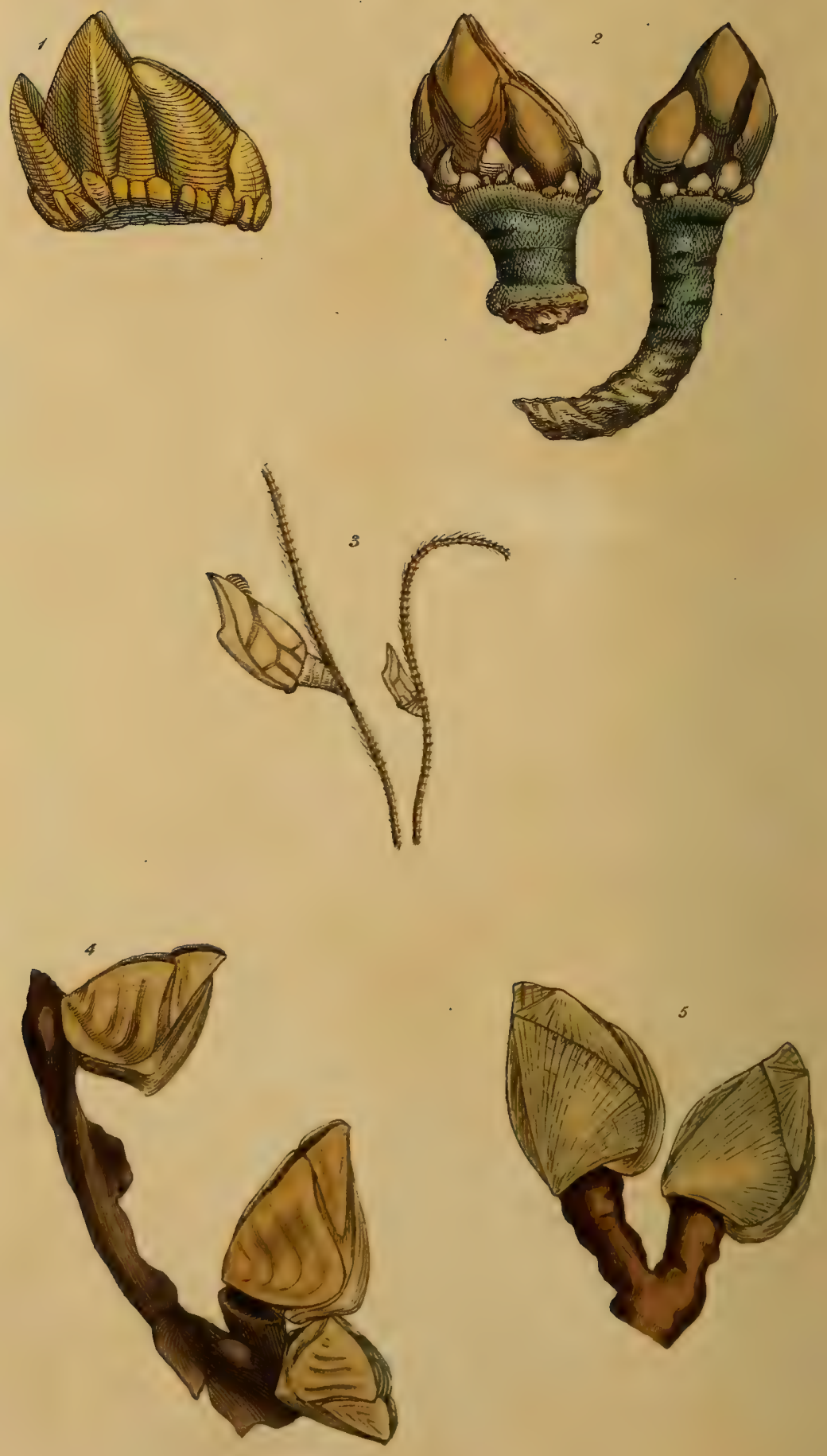




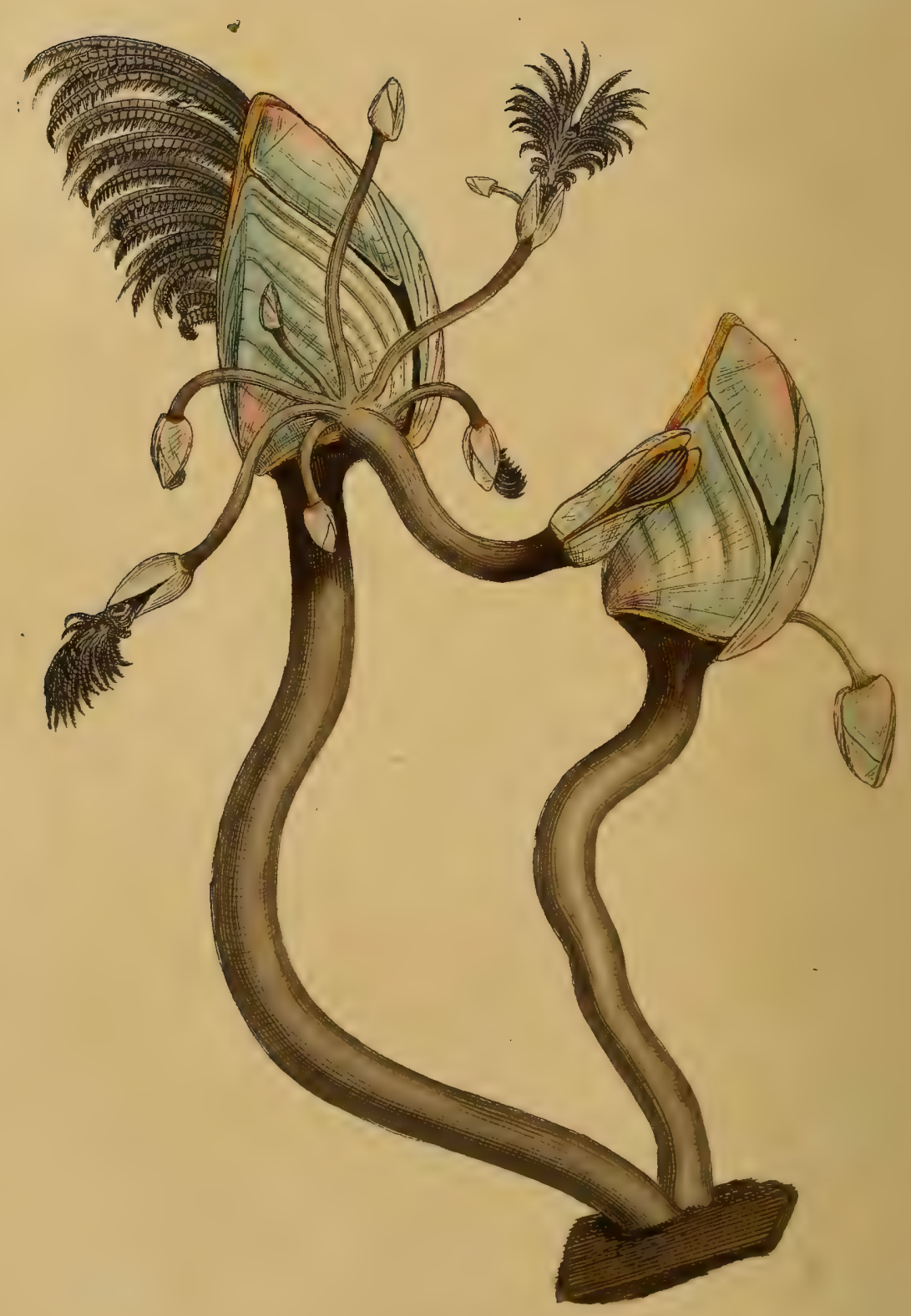




IZPAS.

PI.1\%
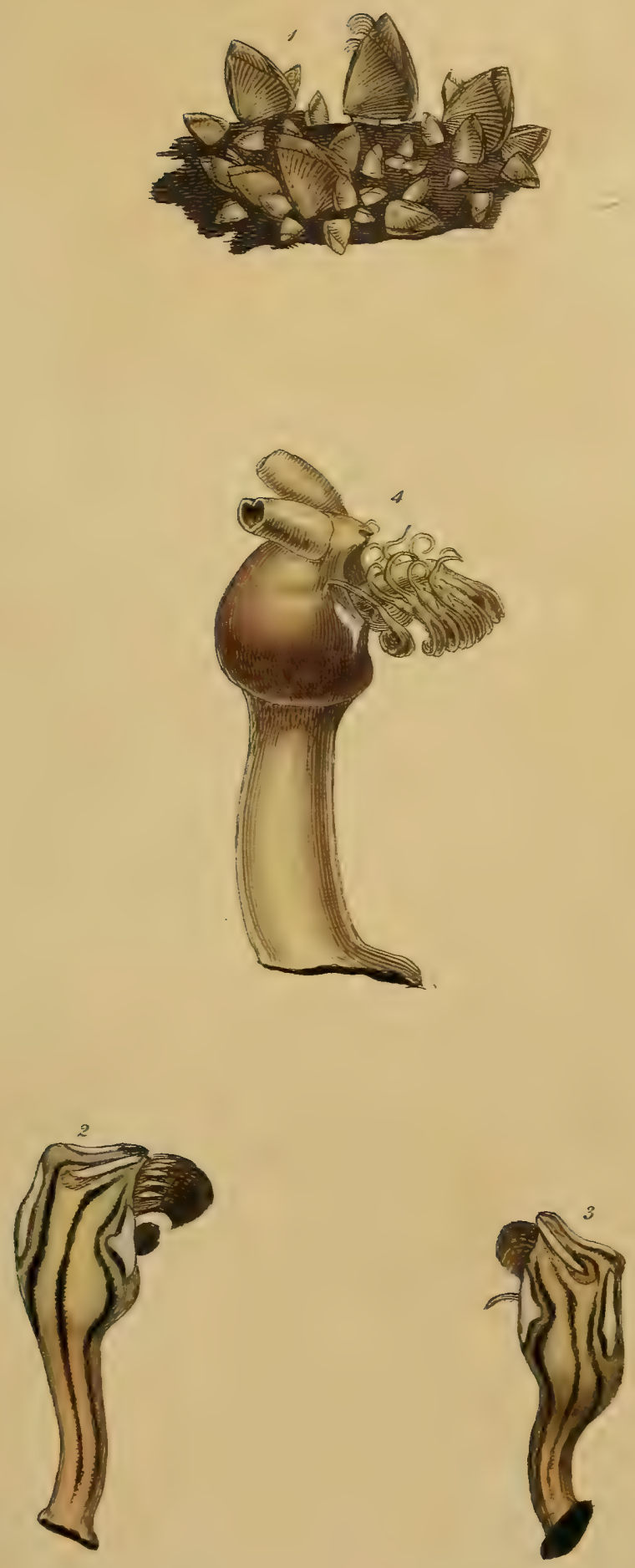



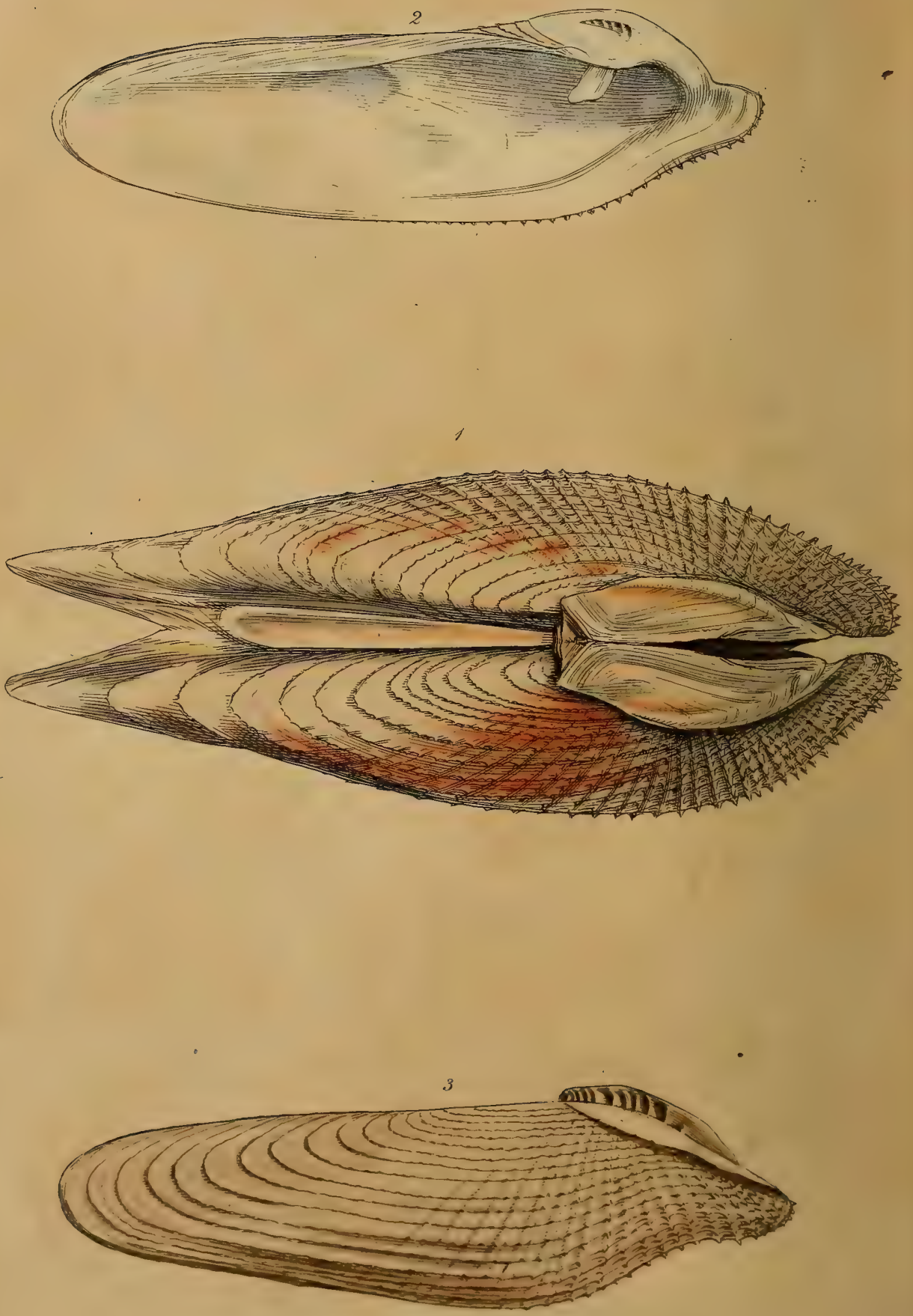
1.23 Plu da duale $=$

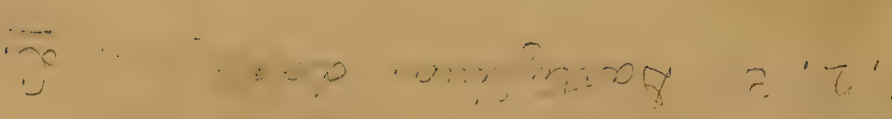

81 


14

$\therefore \quad \because \quad, \quad, 78$

$\cdots+\ldots, 2$ ande

$\therefore$ Eaw a car cand 

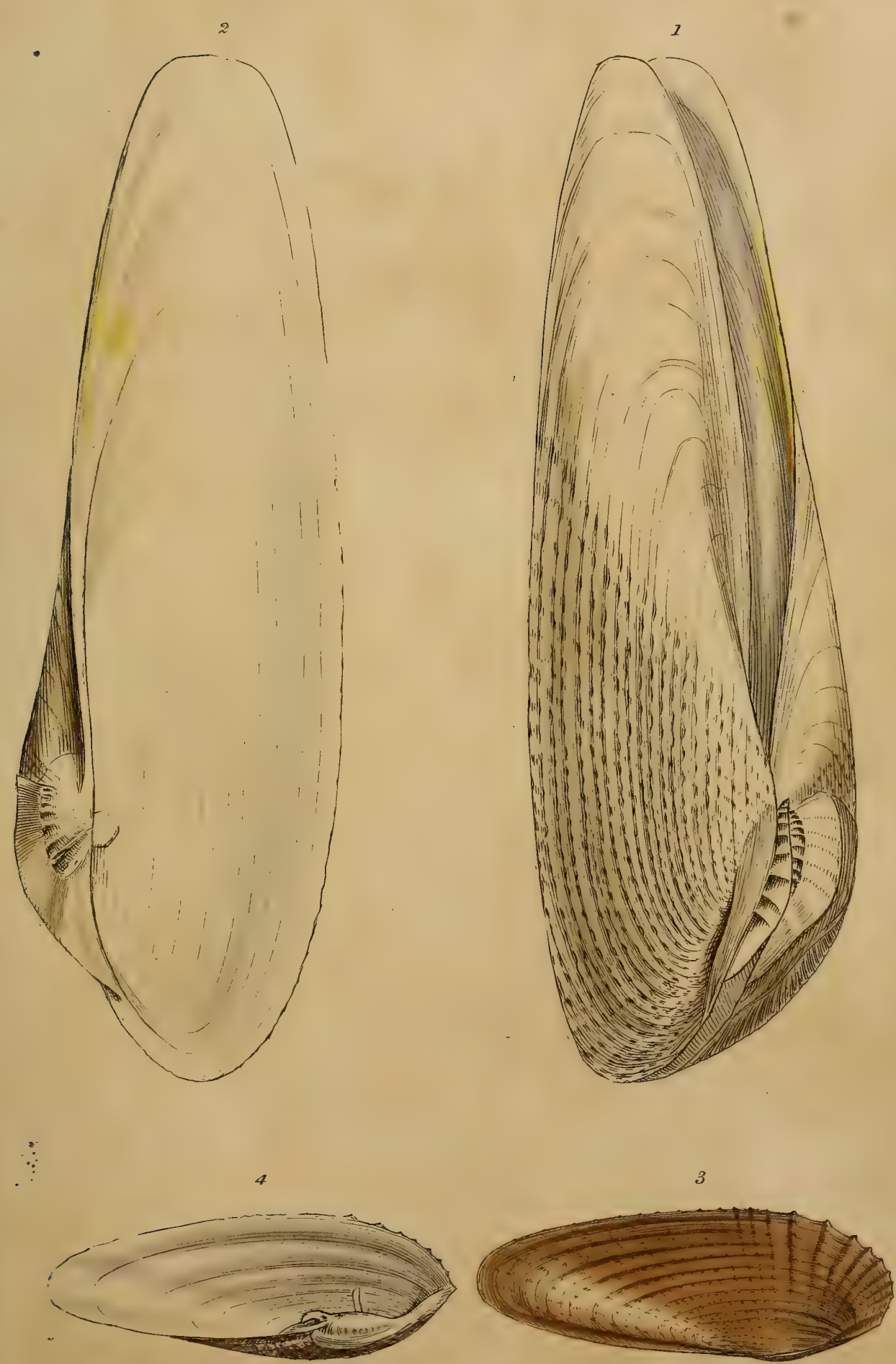




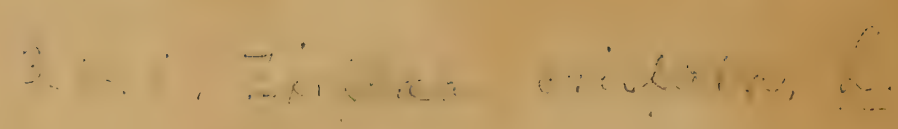



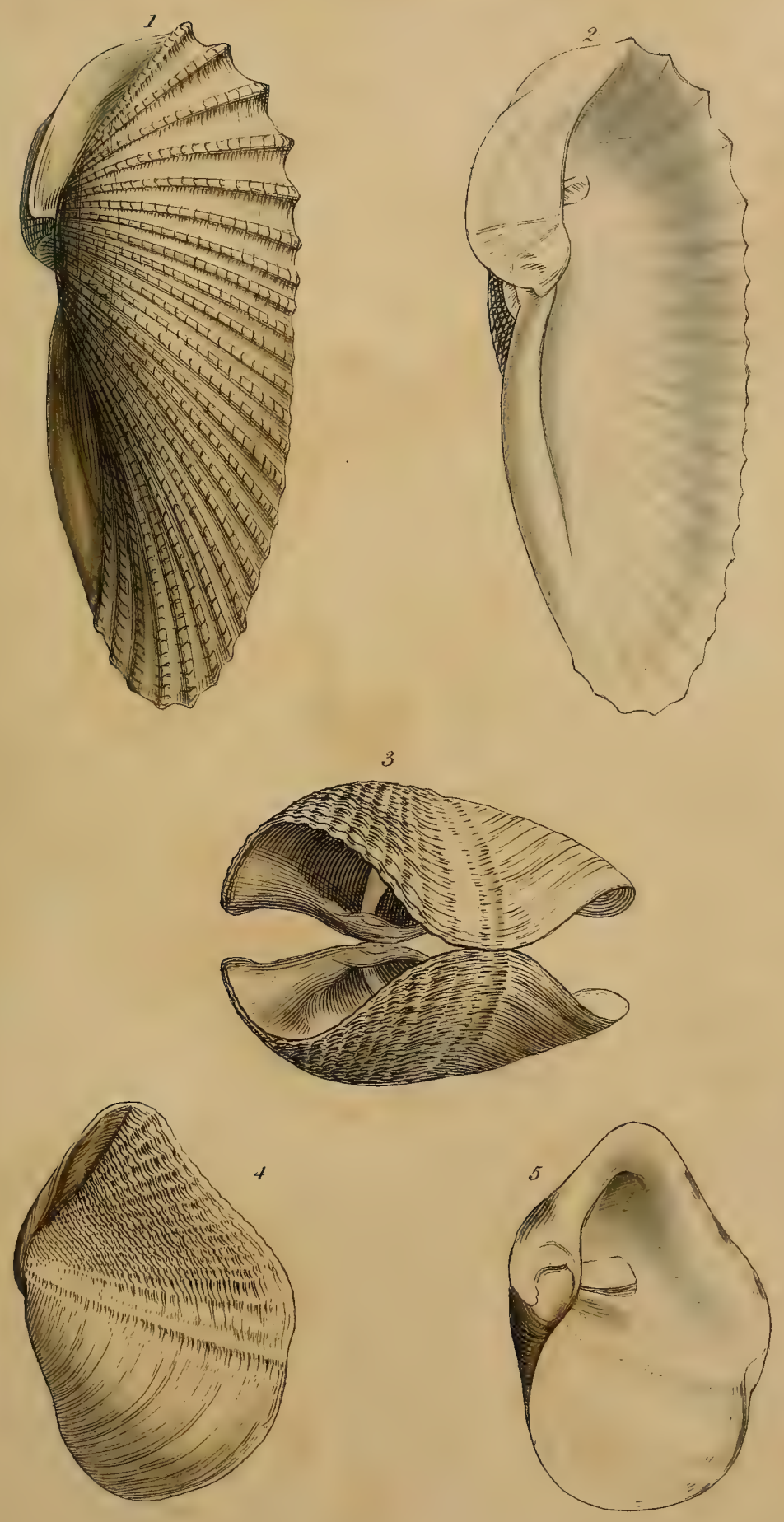



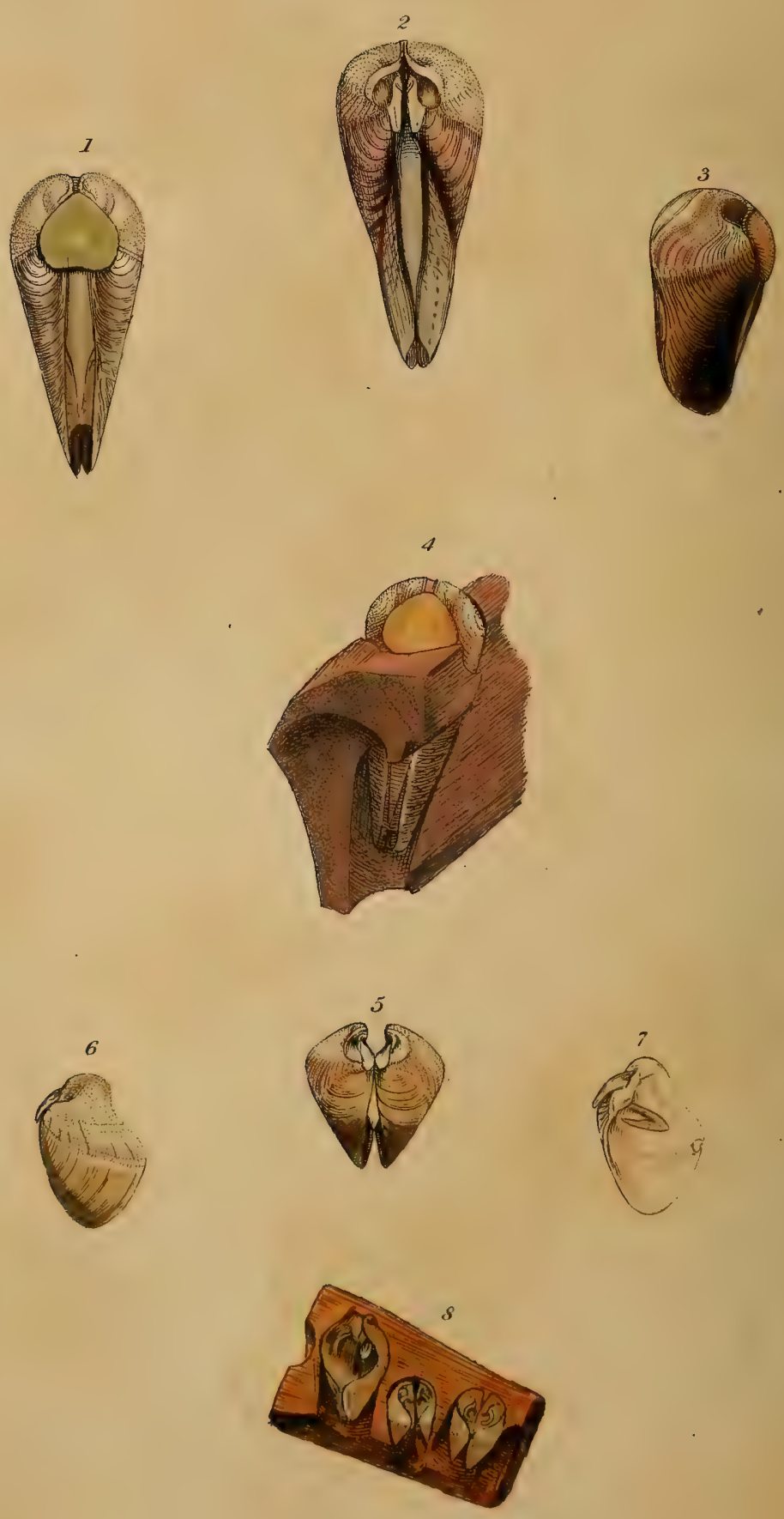
16

$1,2,3,4,8$. Wartesios

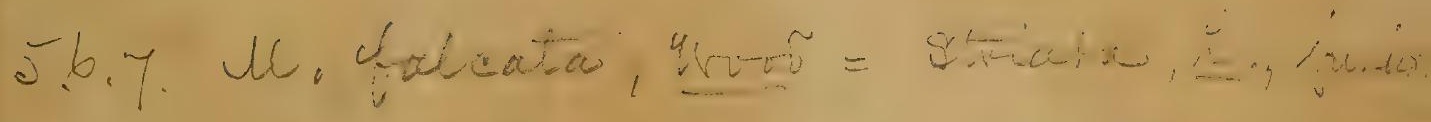
teiso iryou,, $1 \leq$ 


diyo are 


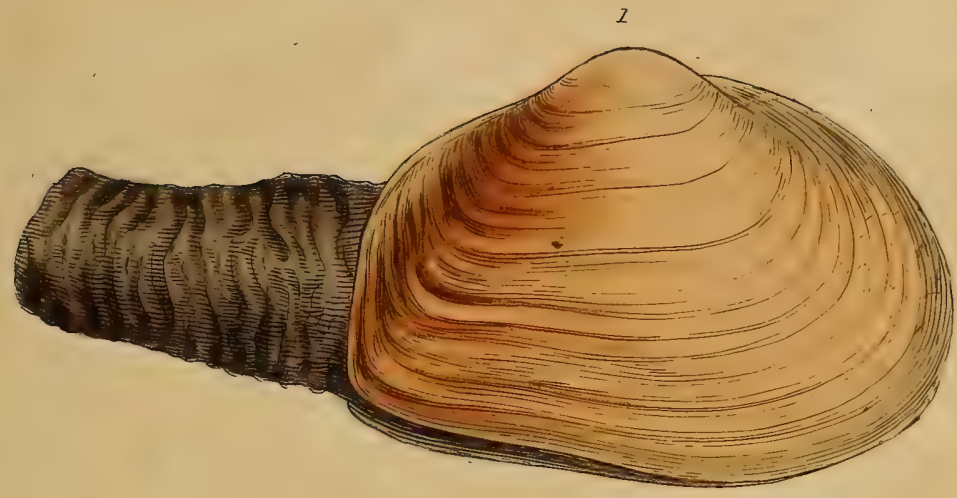

2
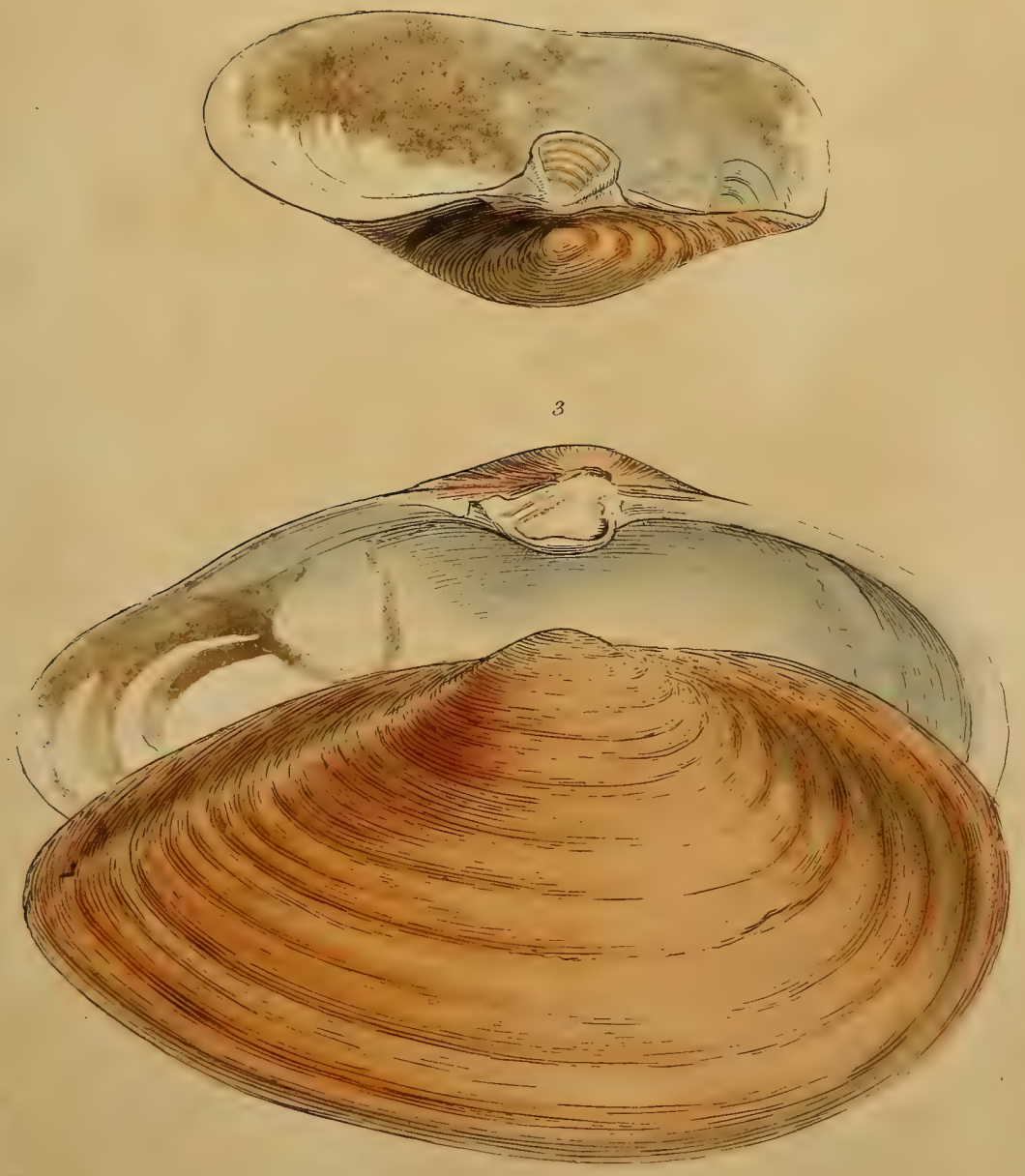



MYA.
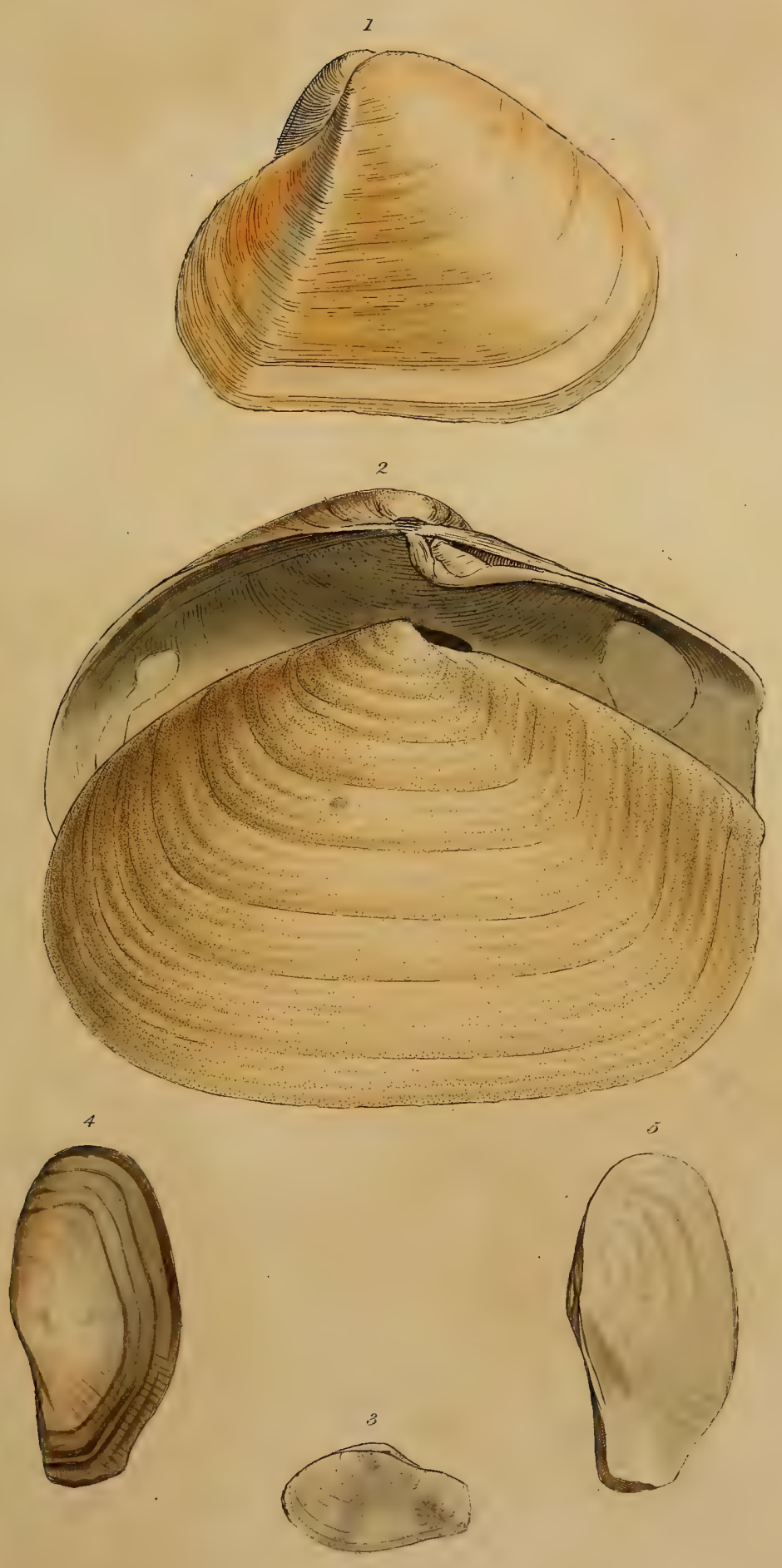


MIIYA 。
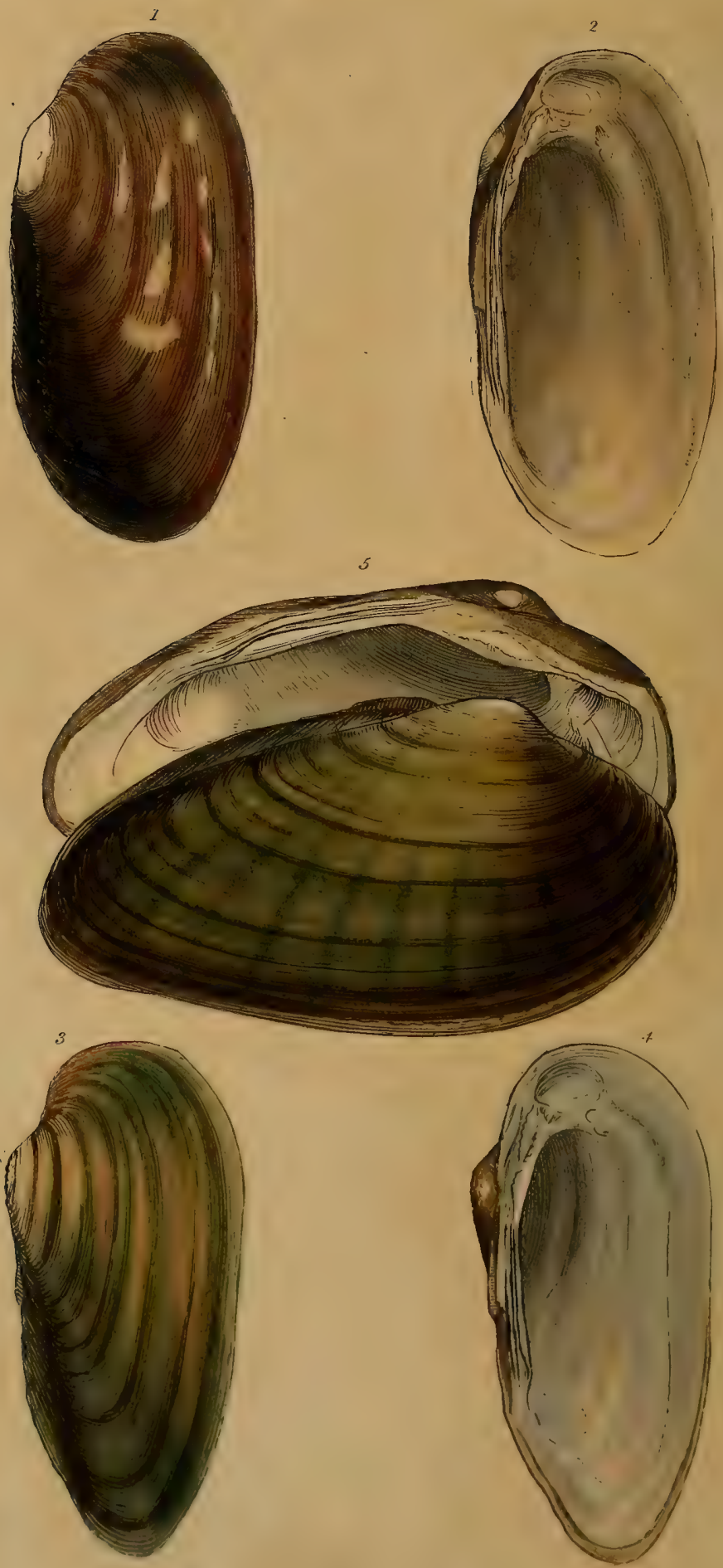
$1=$

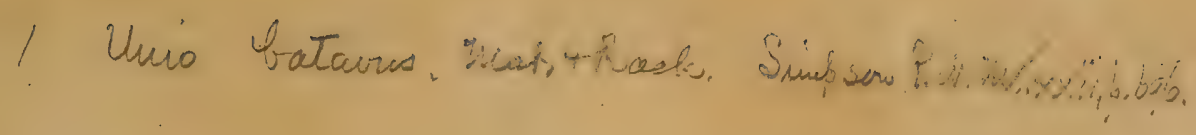

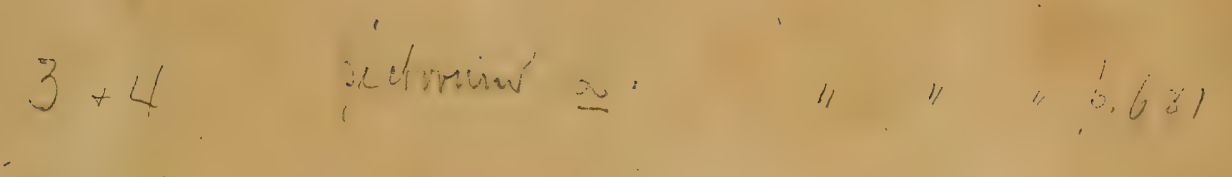

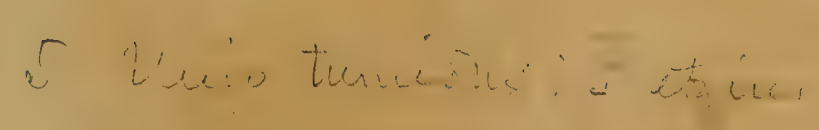

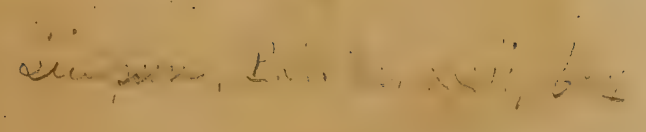






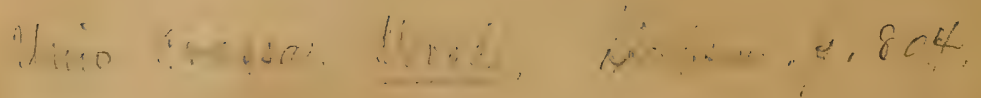




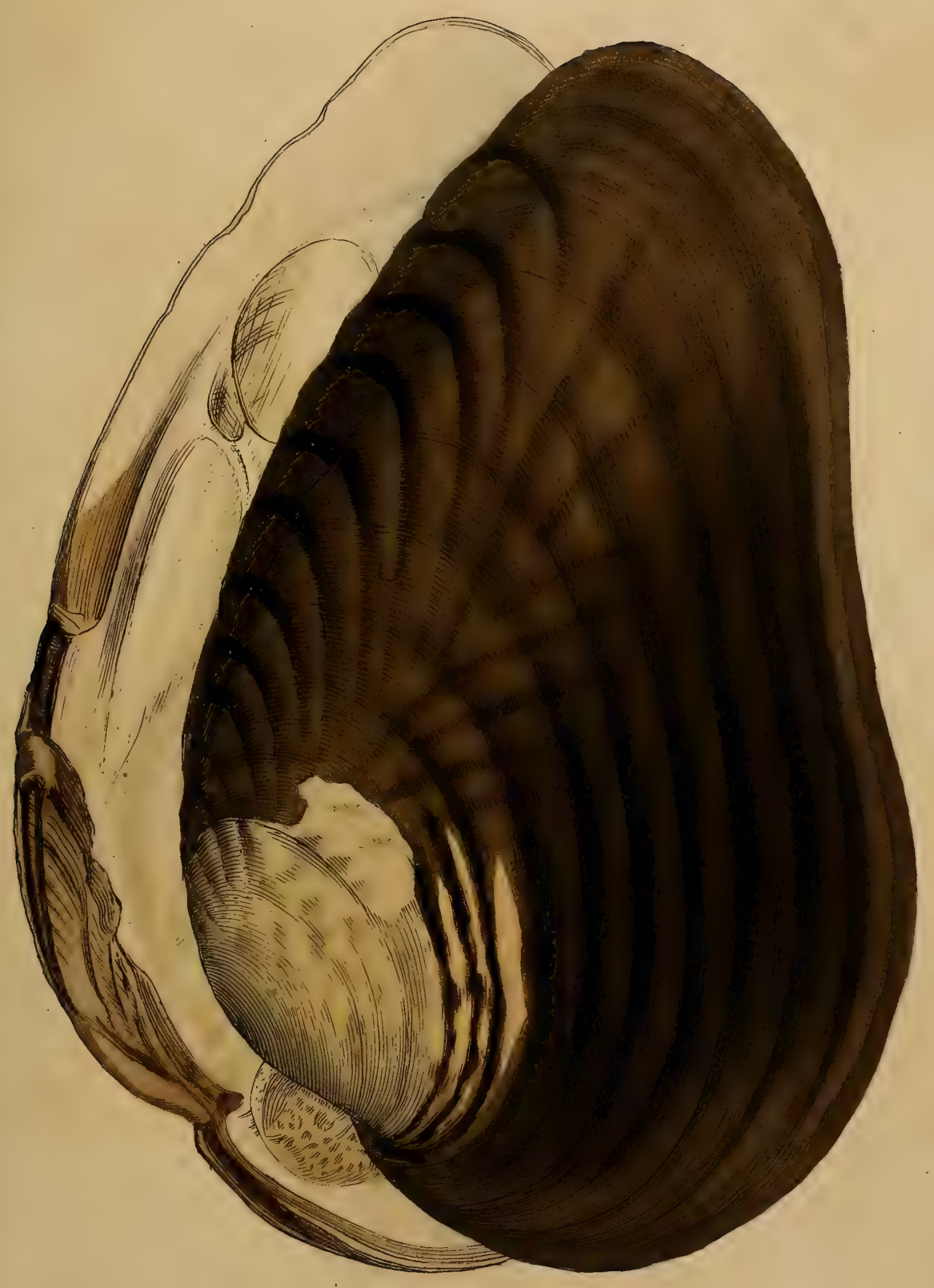






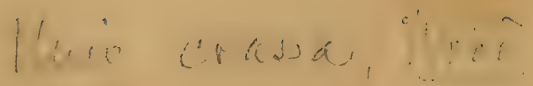

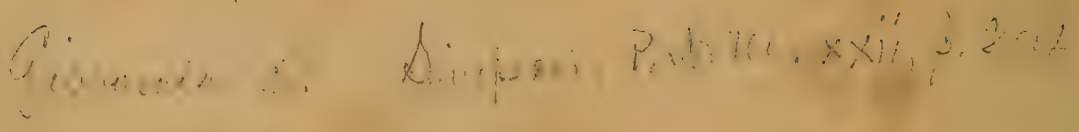




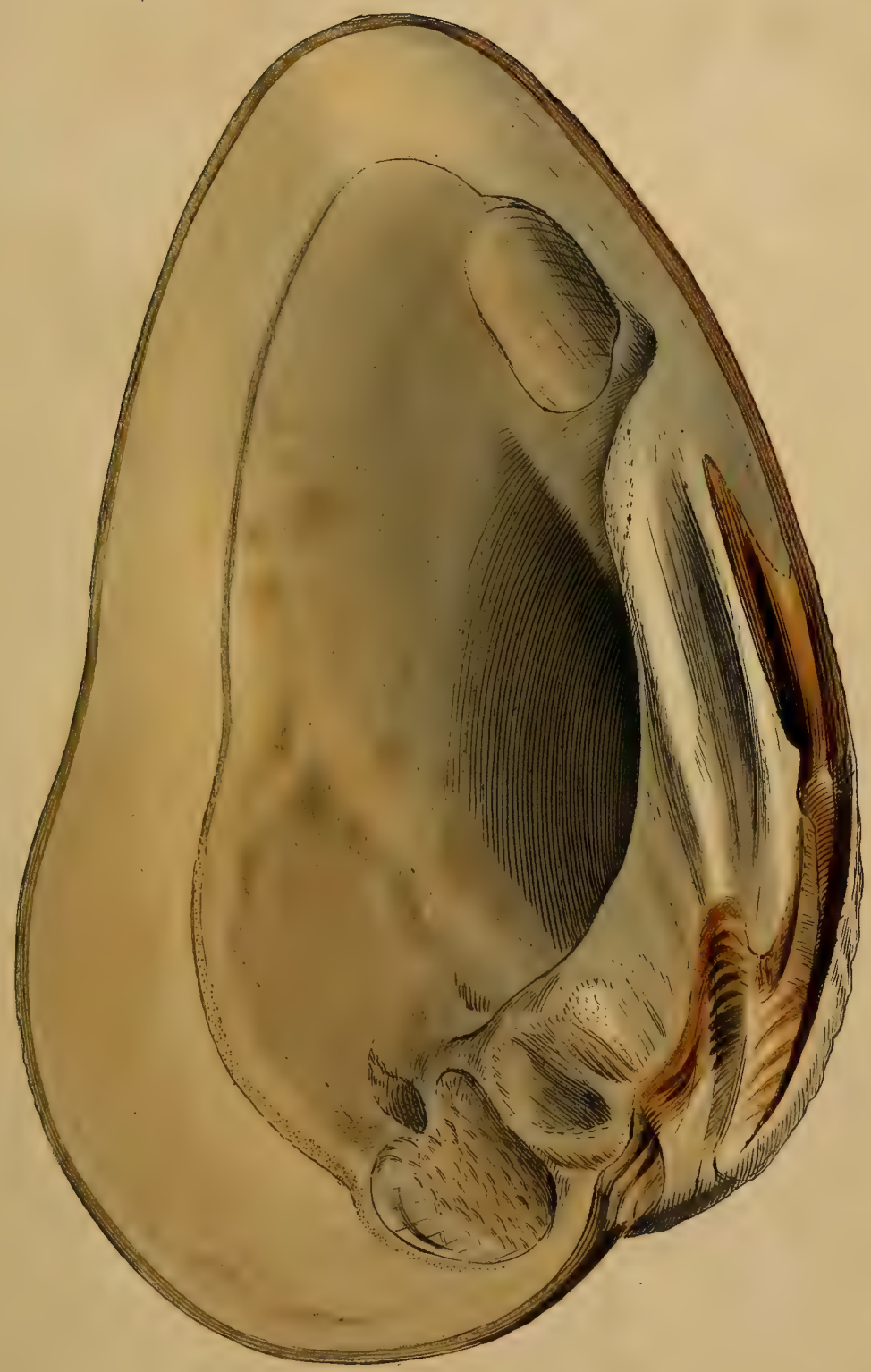




$\therefore 2$

$\therefore \quad \therefore \quad \therefore$.

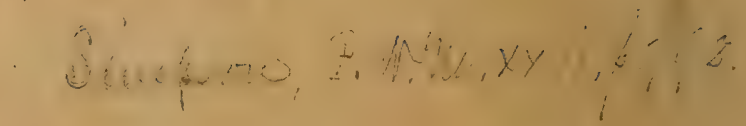

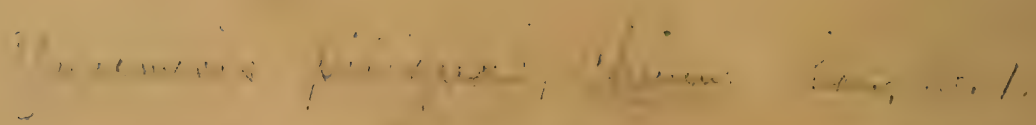

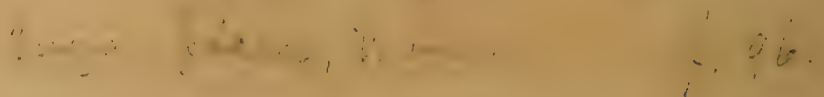

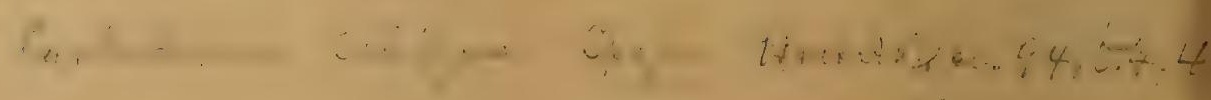



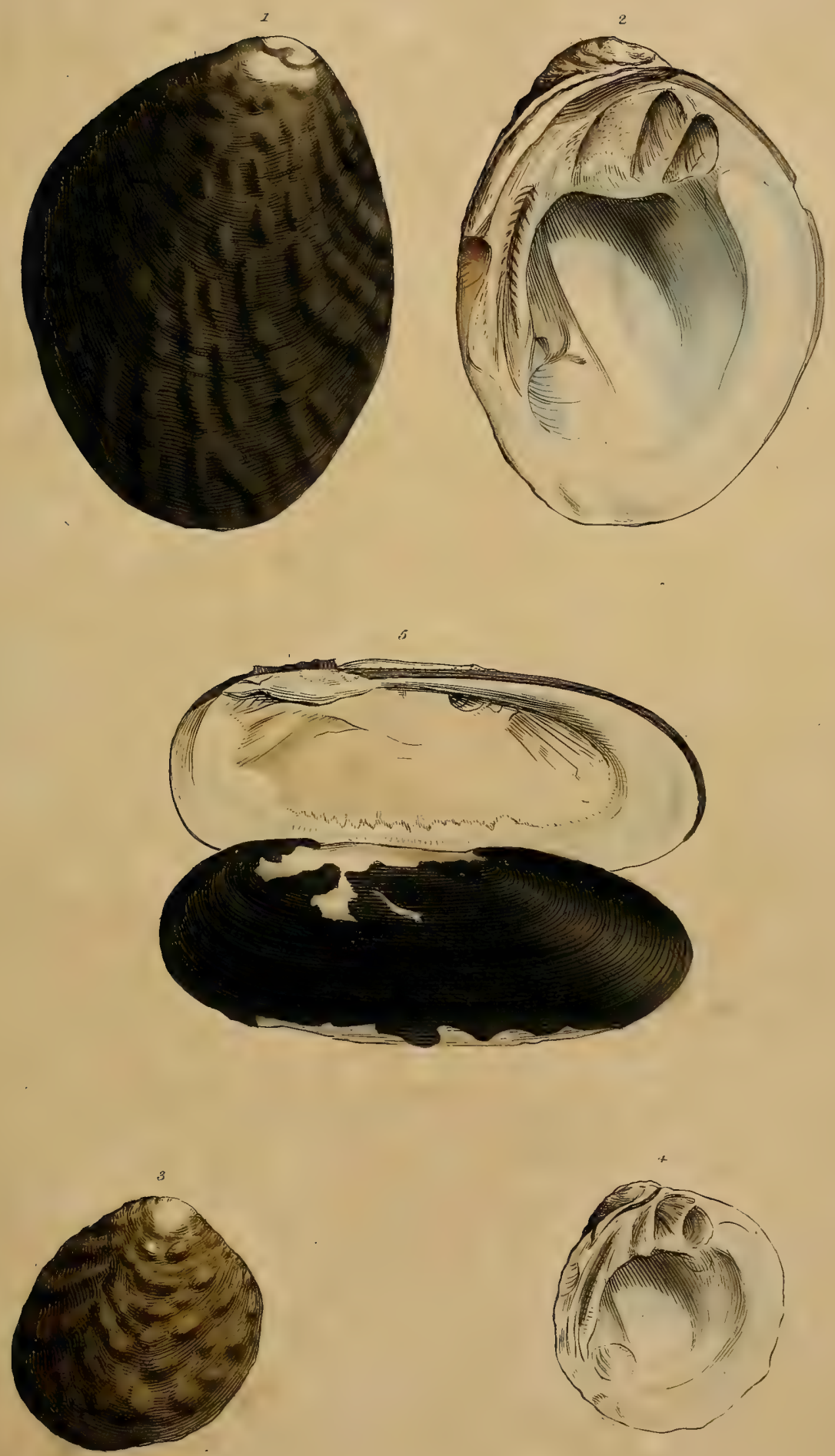



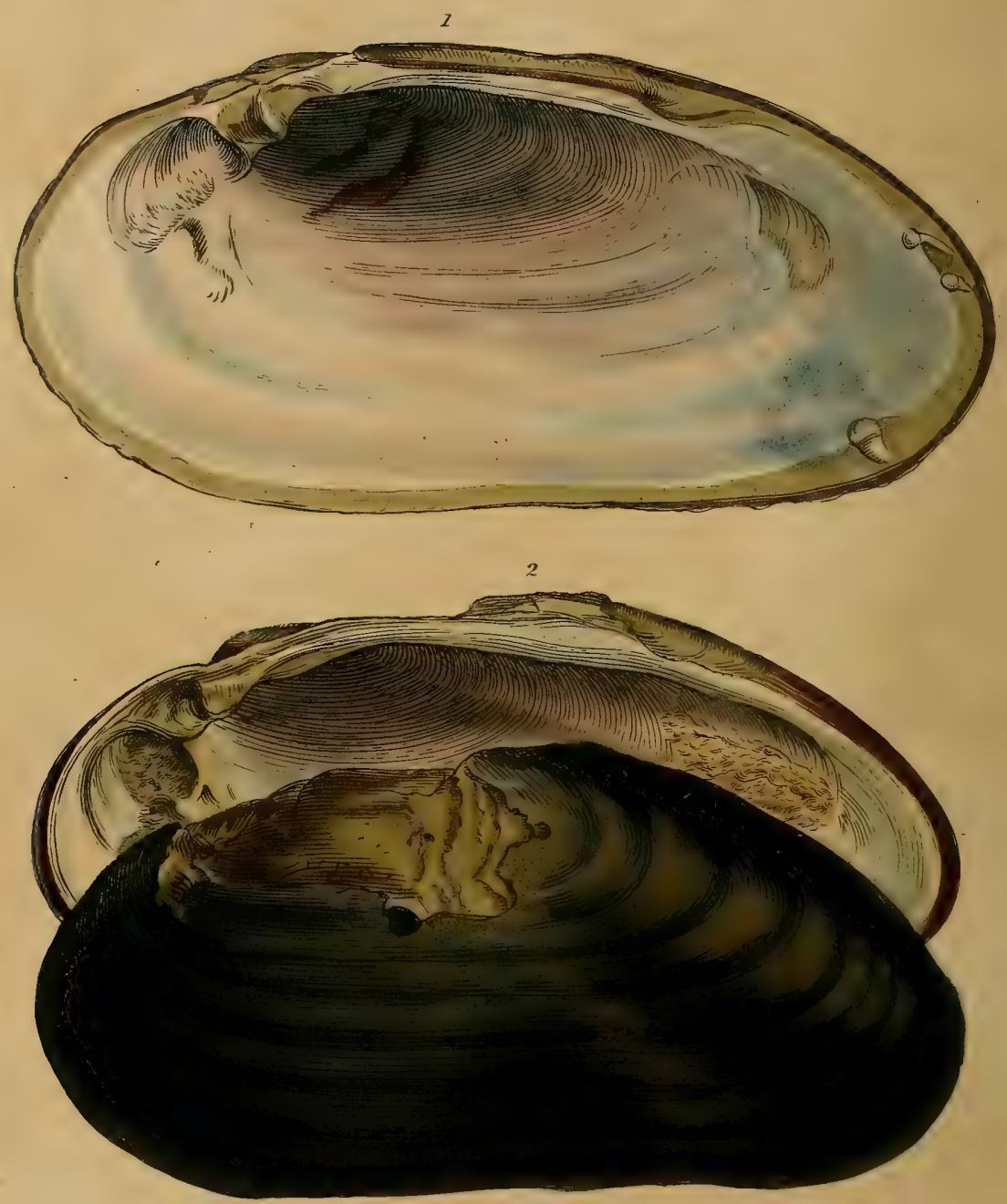

3

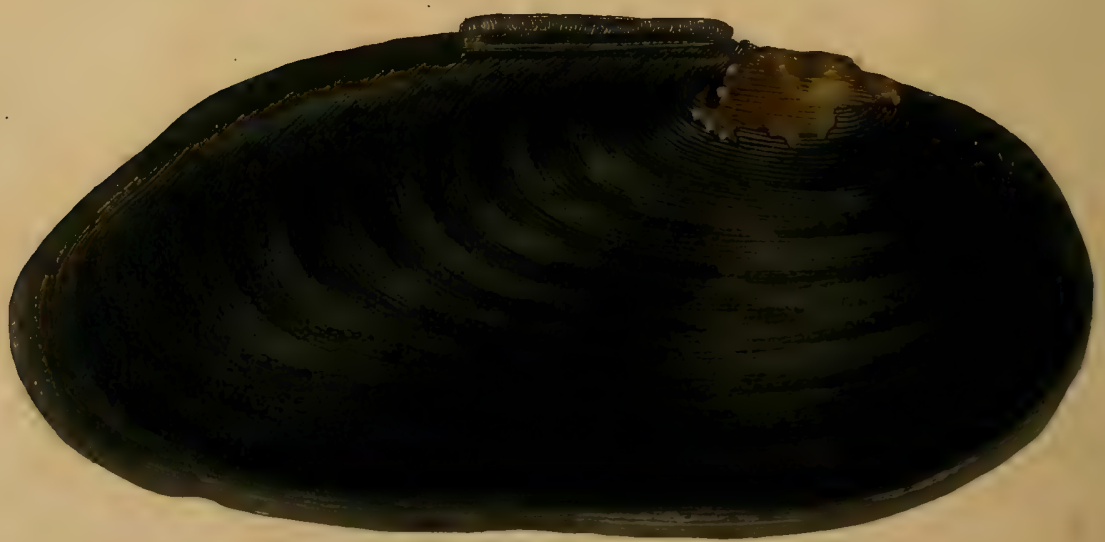




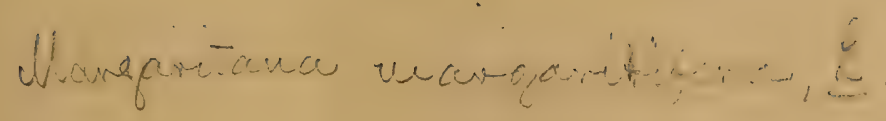

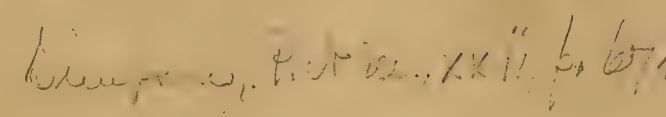




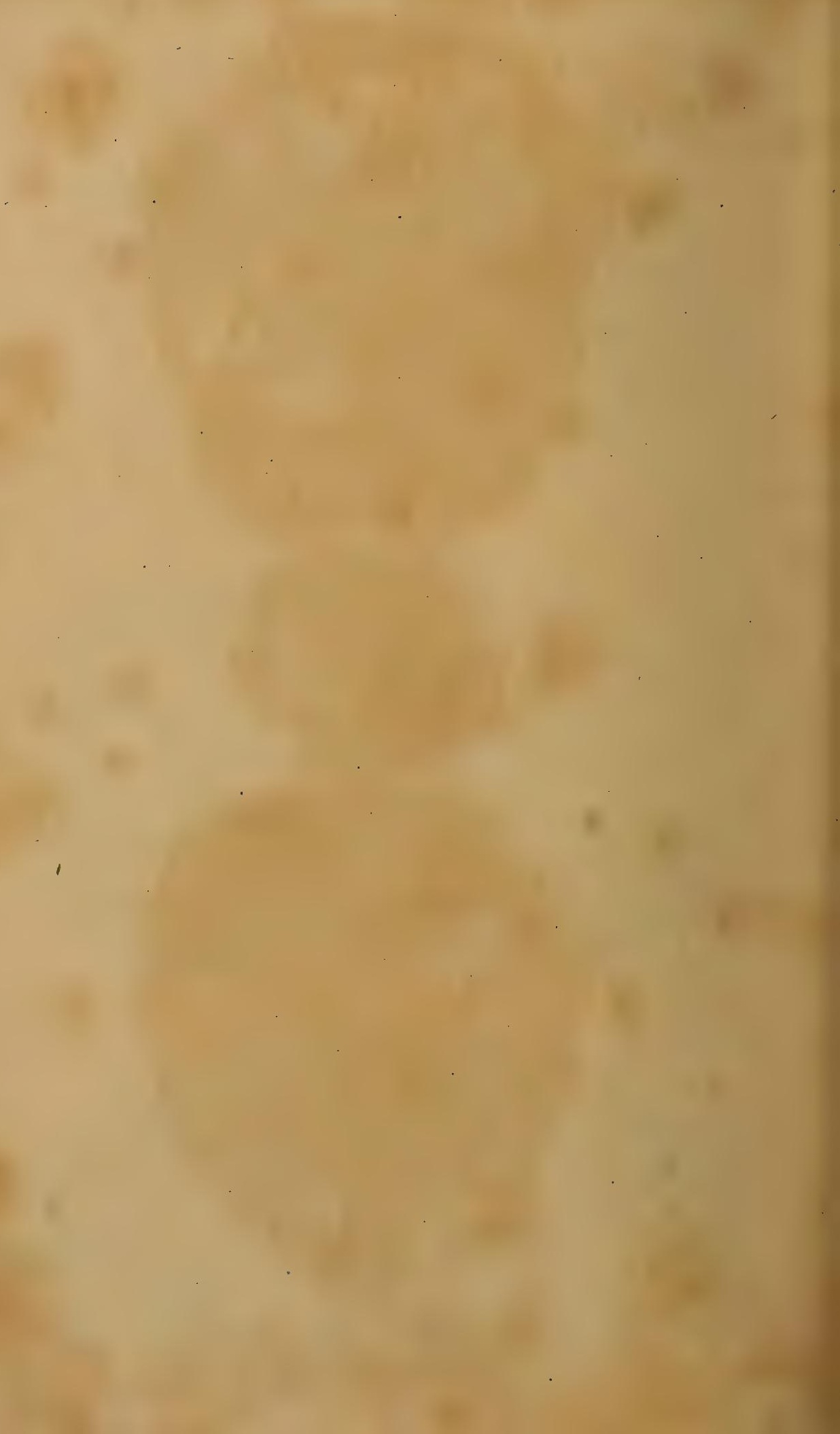



MMYAA
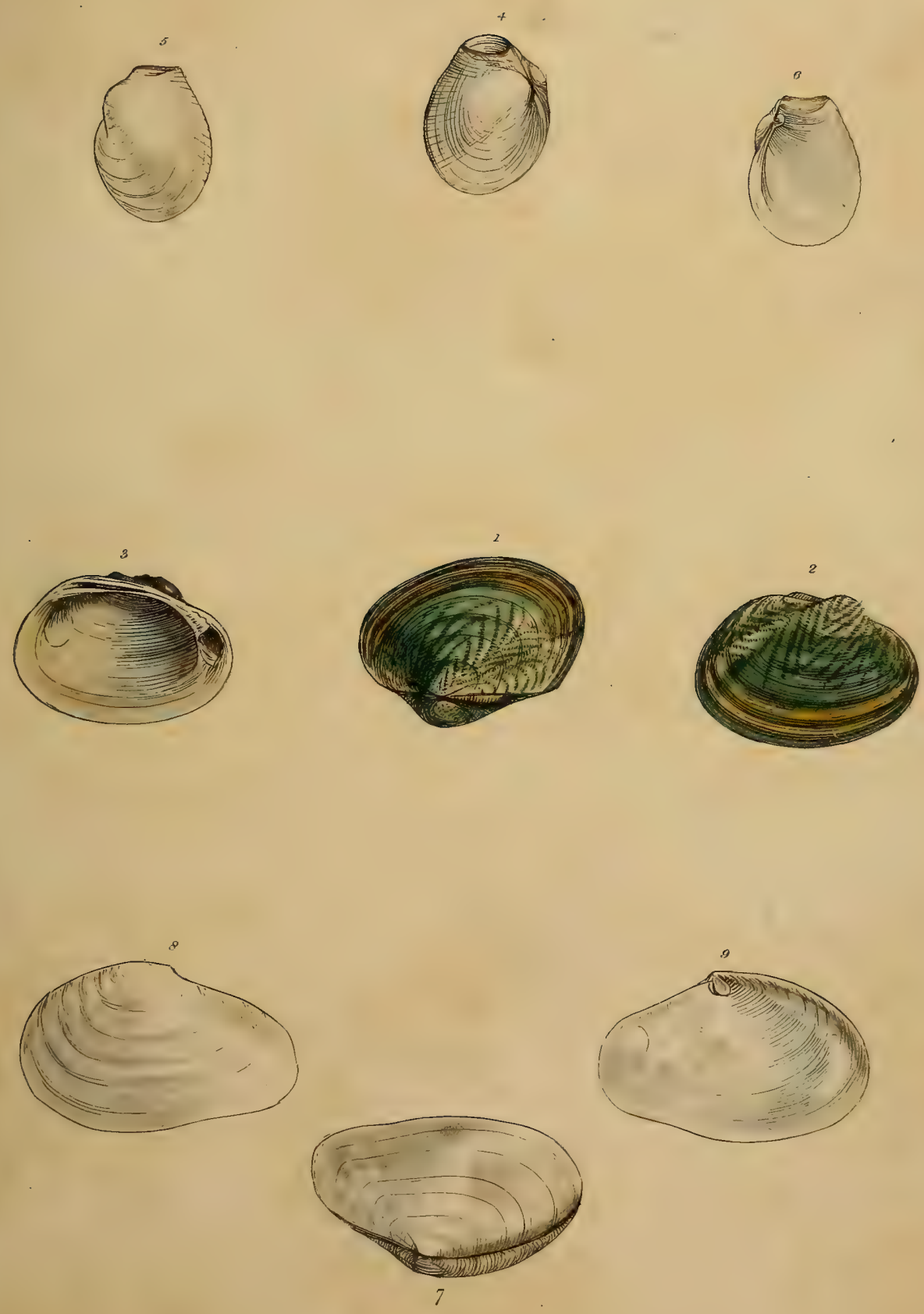




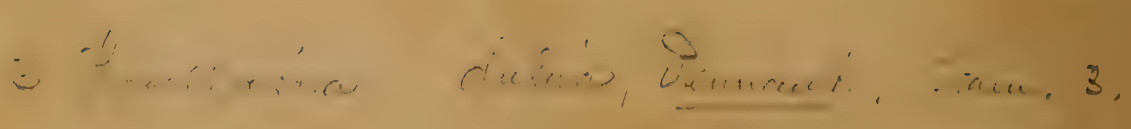




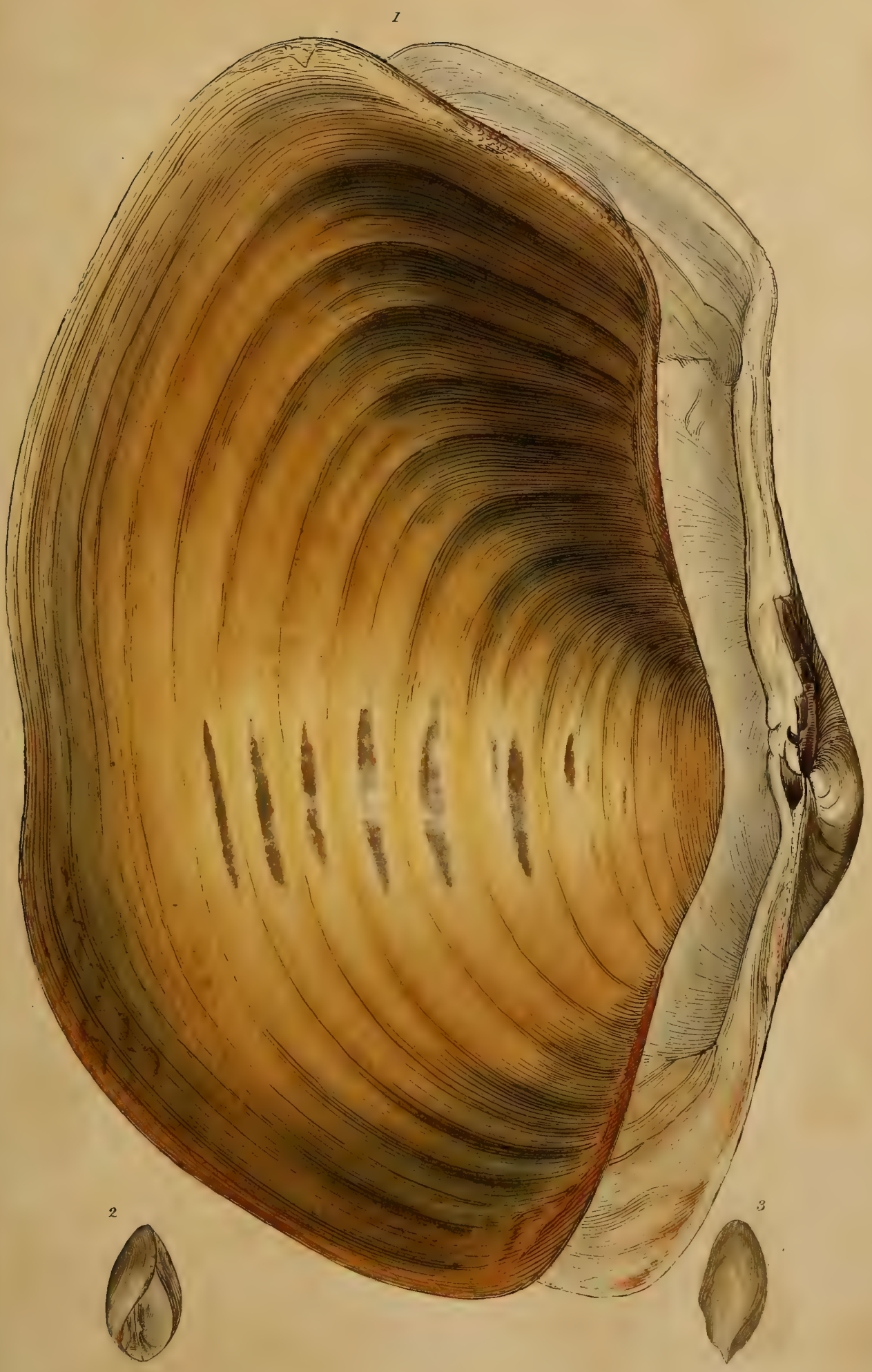





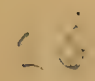

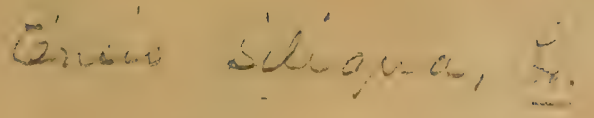

$\therefore: i$

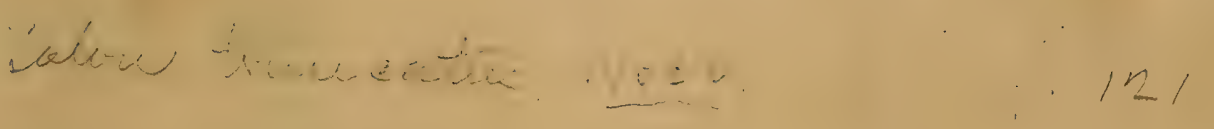



SOMTEN.
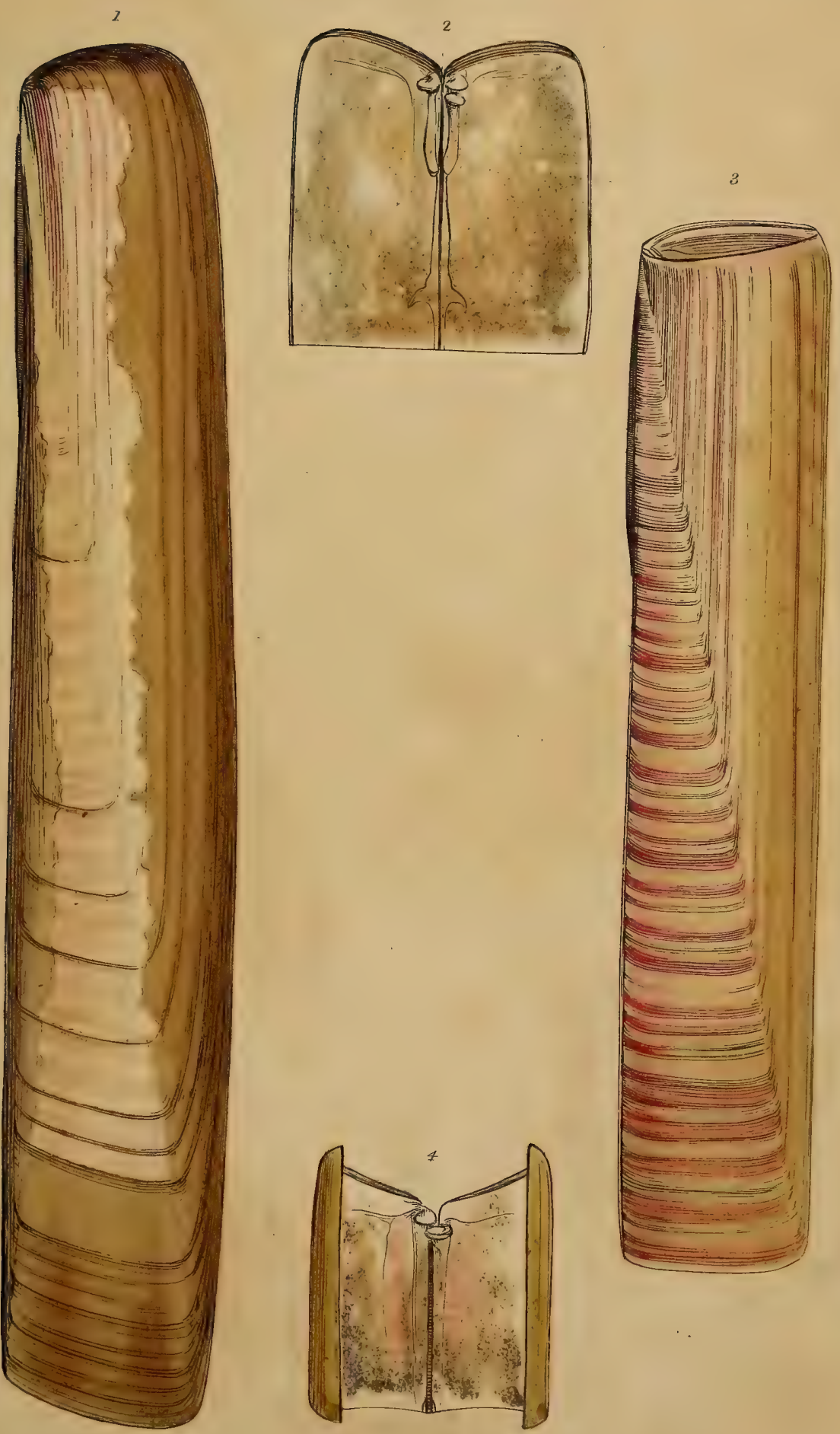

-

N -

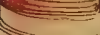

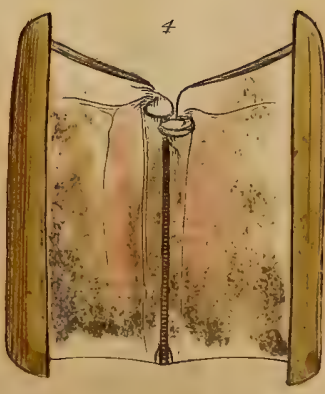

Nis

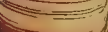

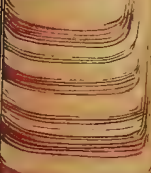

$+x=$

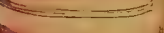

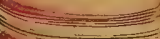
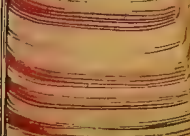

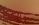
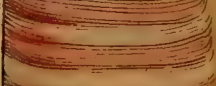

D

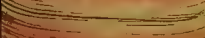

$x=-1$.

$-$ 



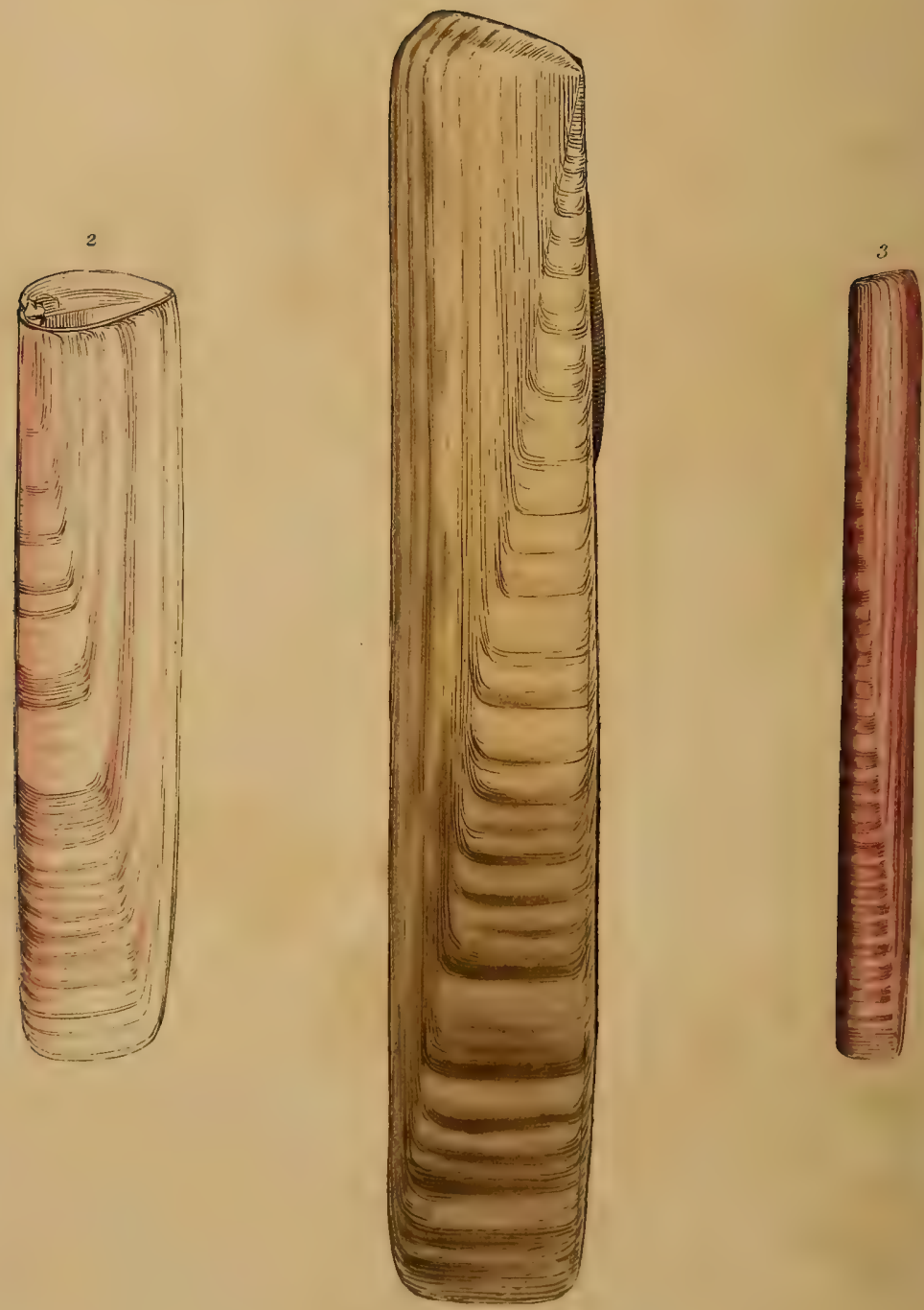
$2 \%$

1. Solew zuacinas: d.

1.19.

i. truvucatus 1reas, w.

tis i i

s. Linea, it,

10.121 


$$
\begin{aligned}
& 1.01 \\
& 101
\end{aligned}
$$





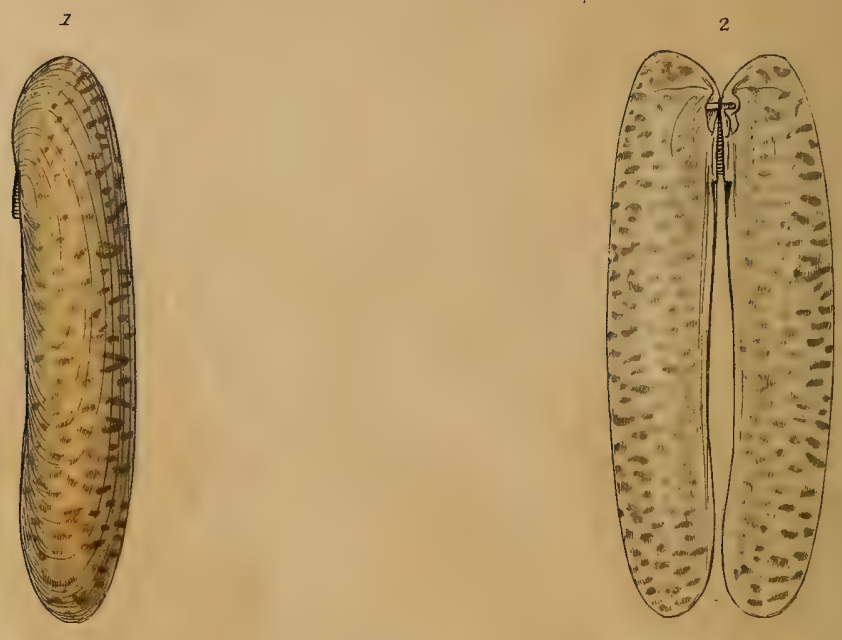

3
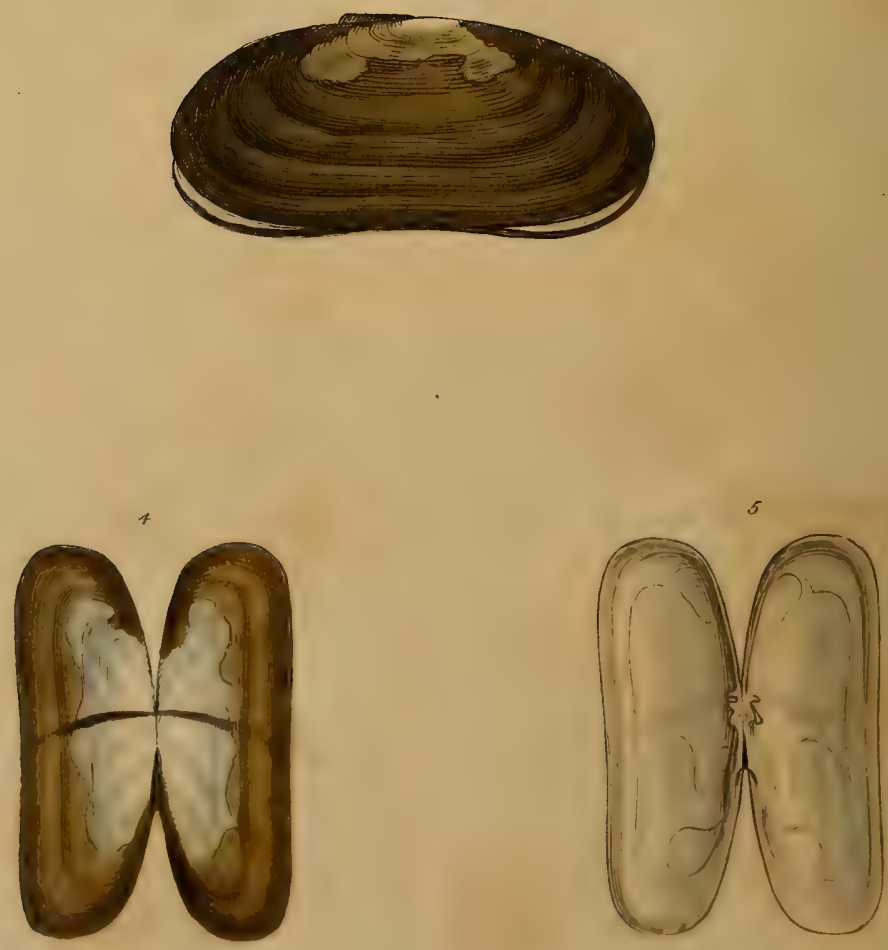



$$
-
$$



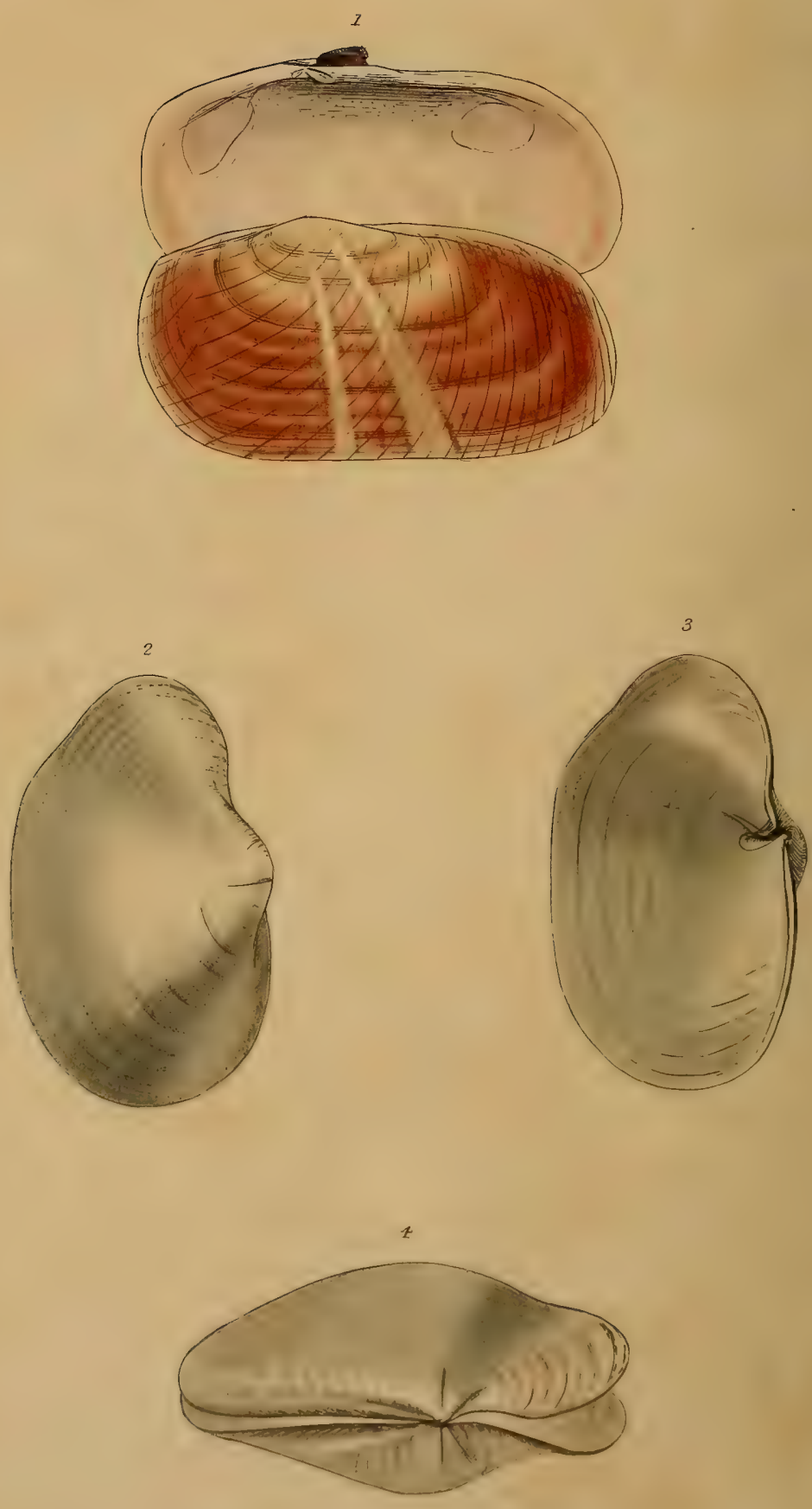
30.

Madia strigillata 2

$f .12$

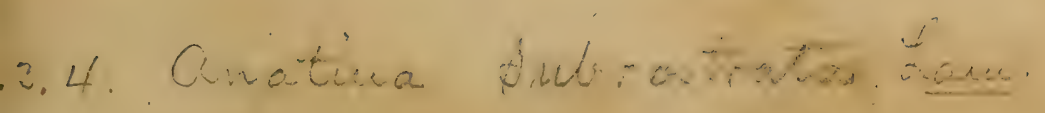



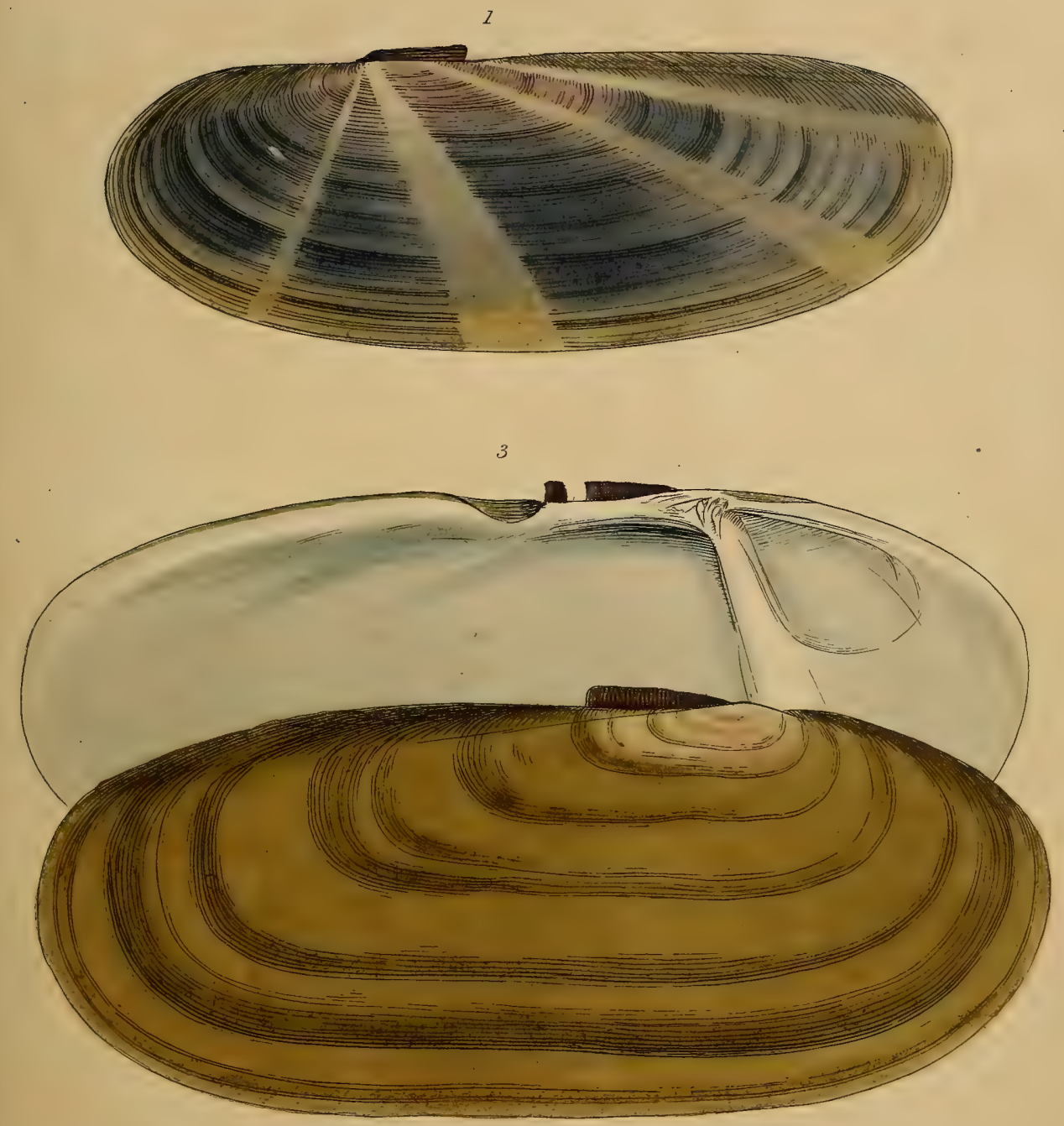

2

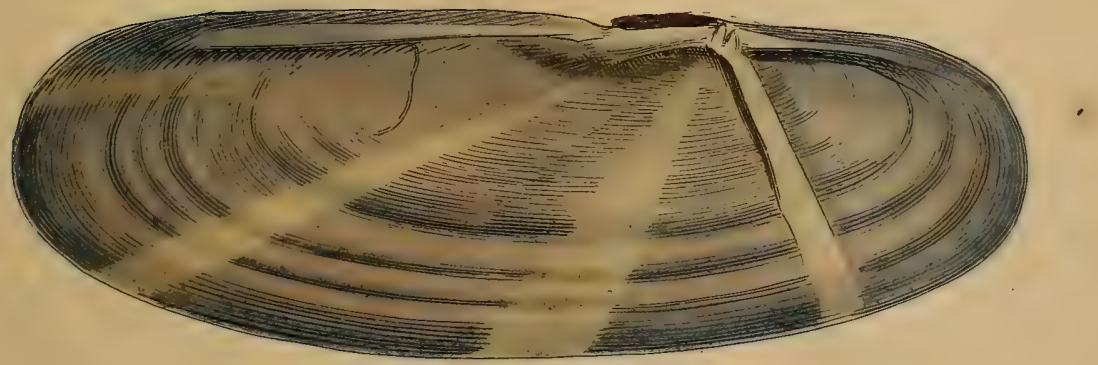





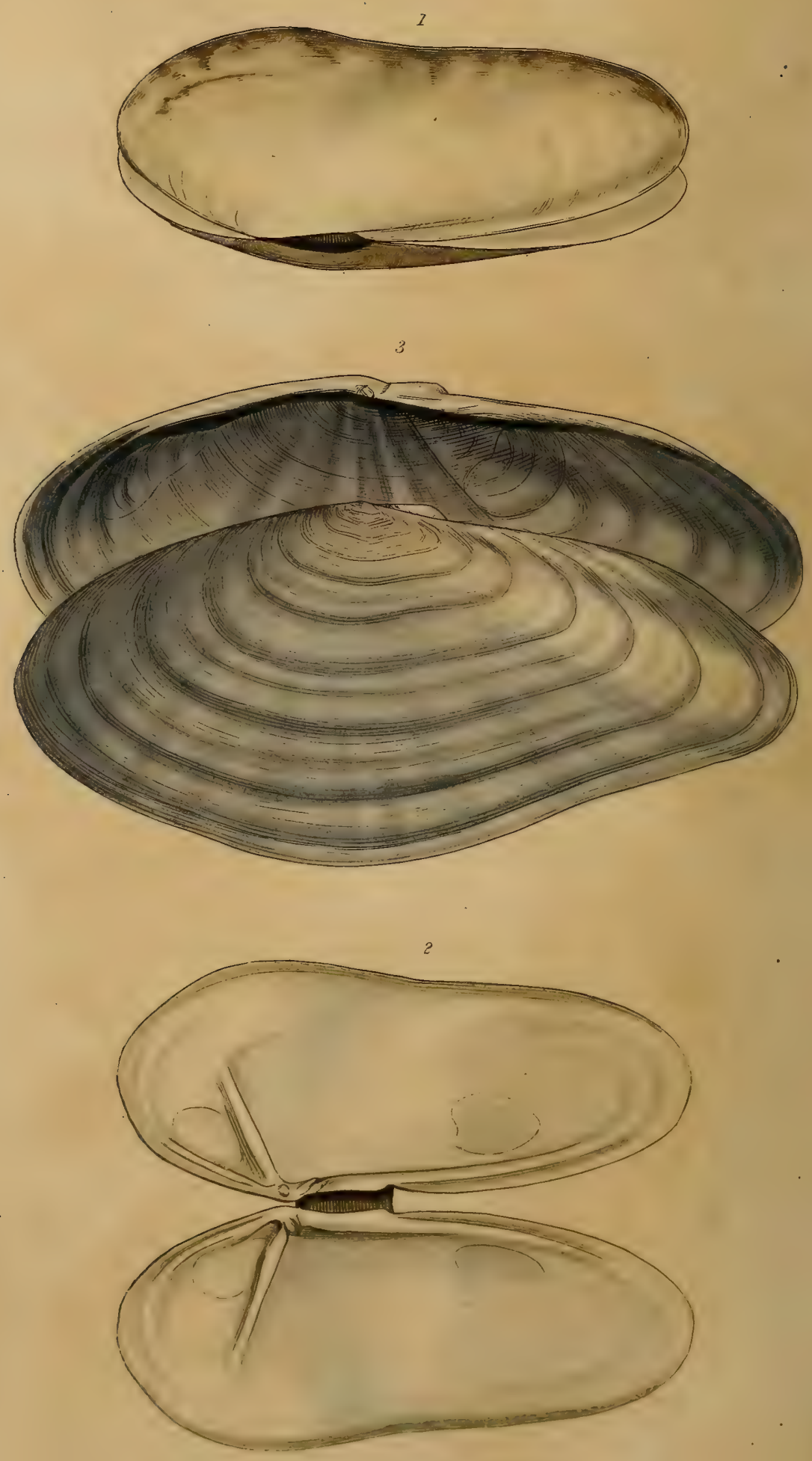



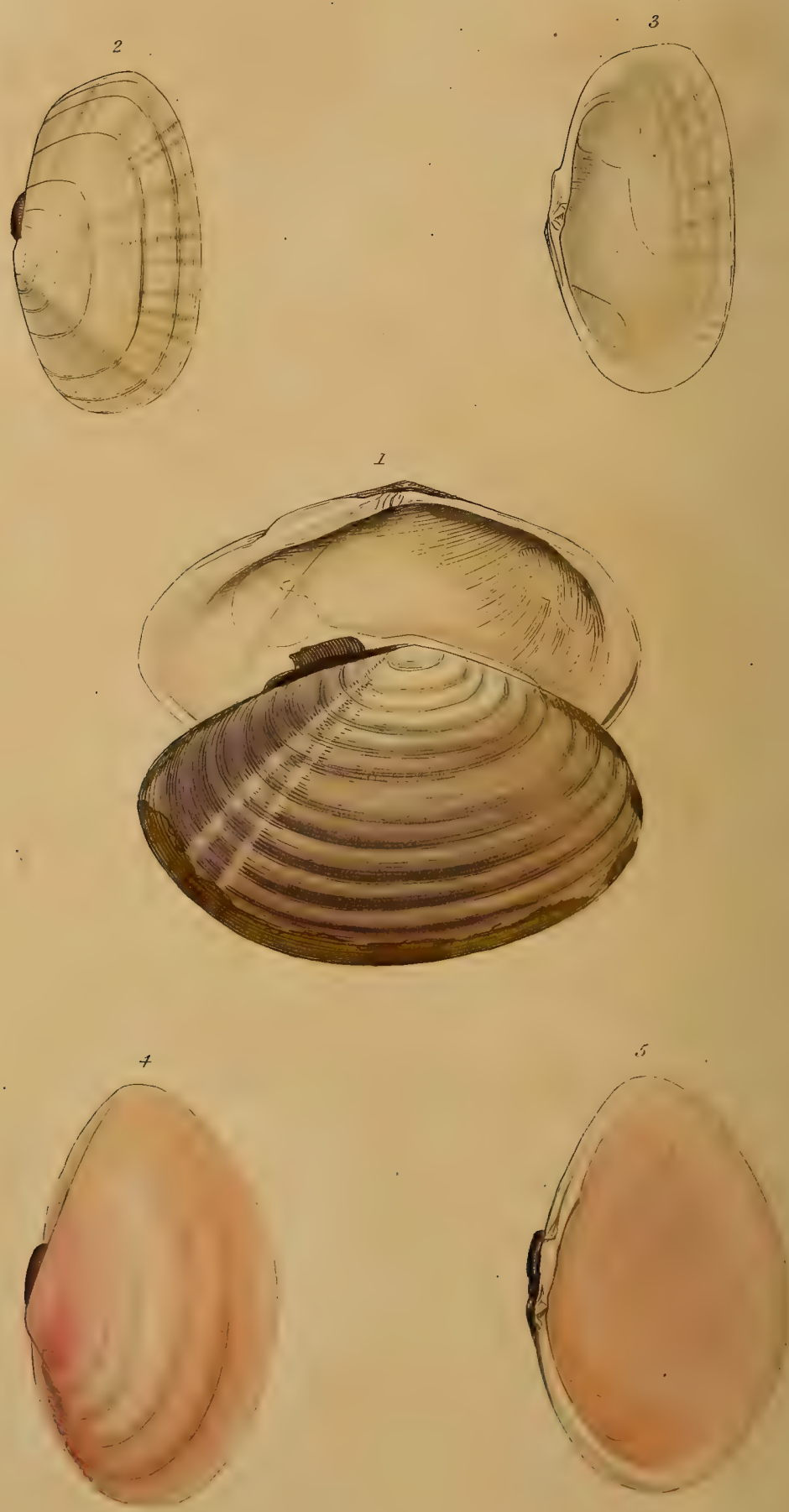
34

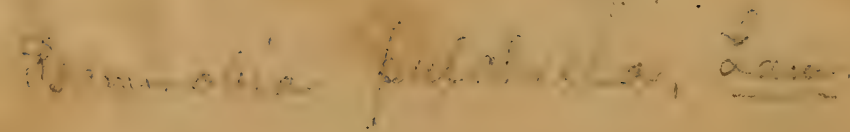

6,138

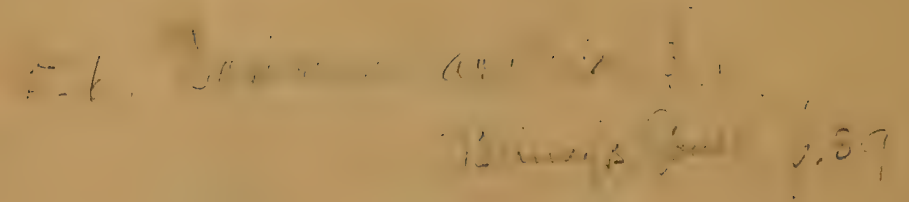



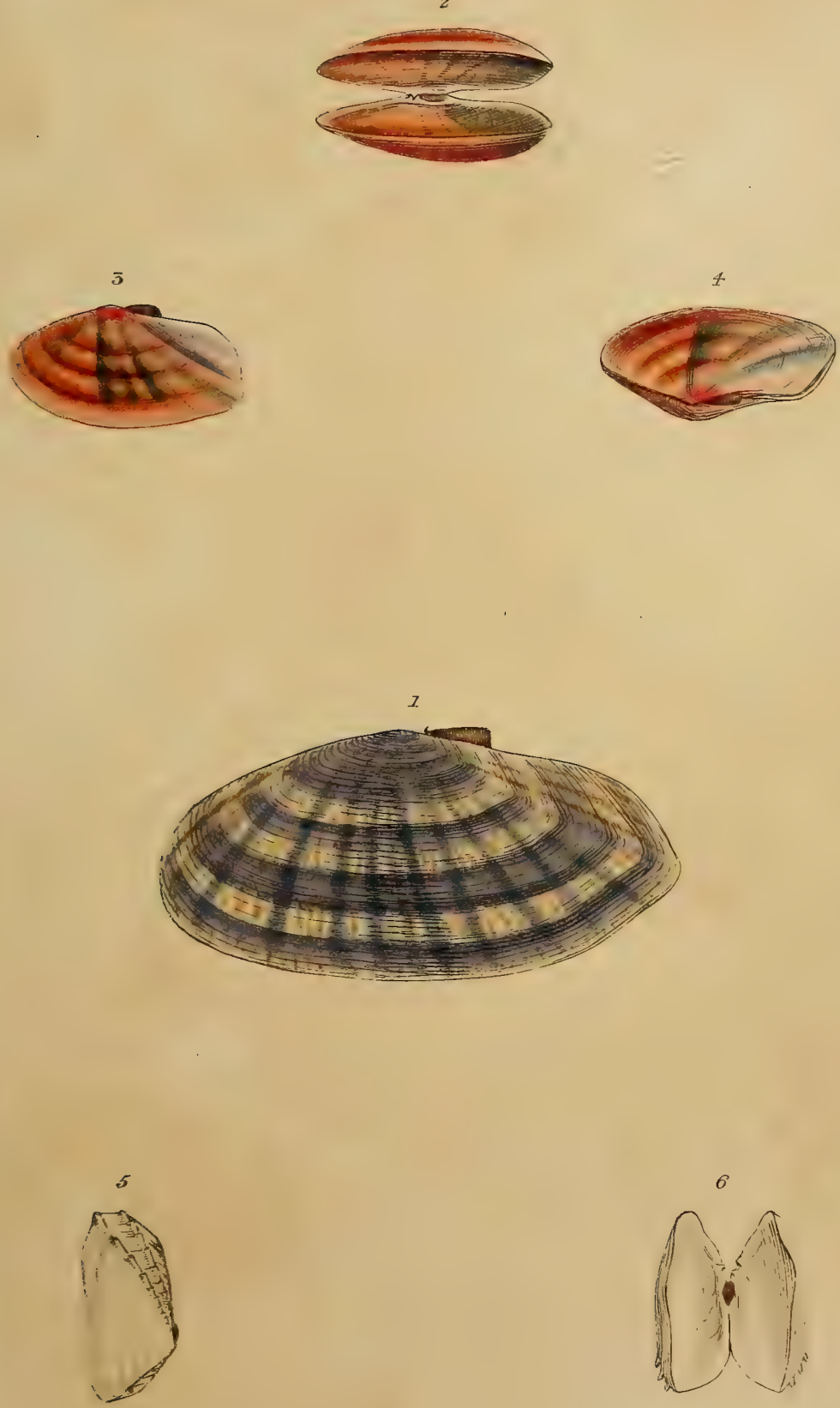
-3. 35

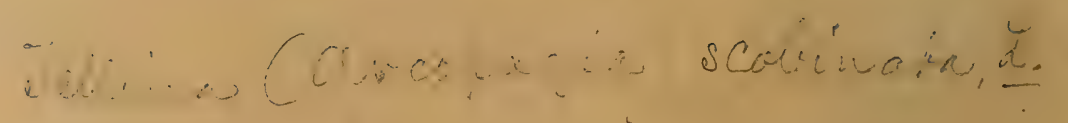

$2+\infty \quad(i+1) \quad v_{0} 3$ 

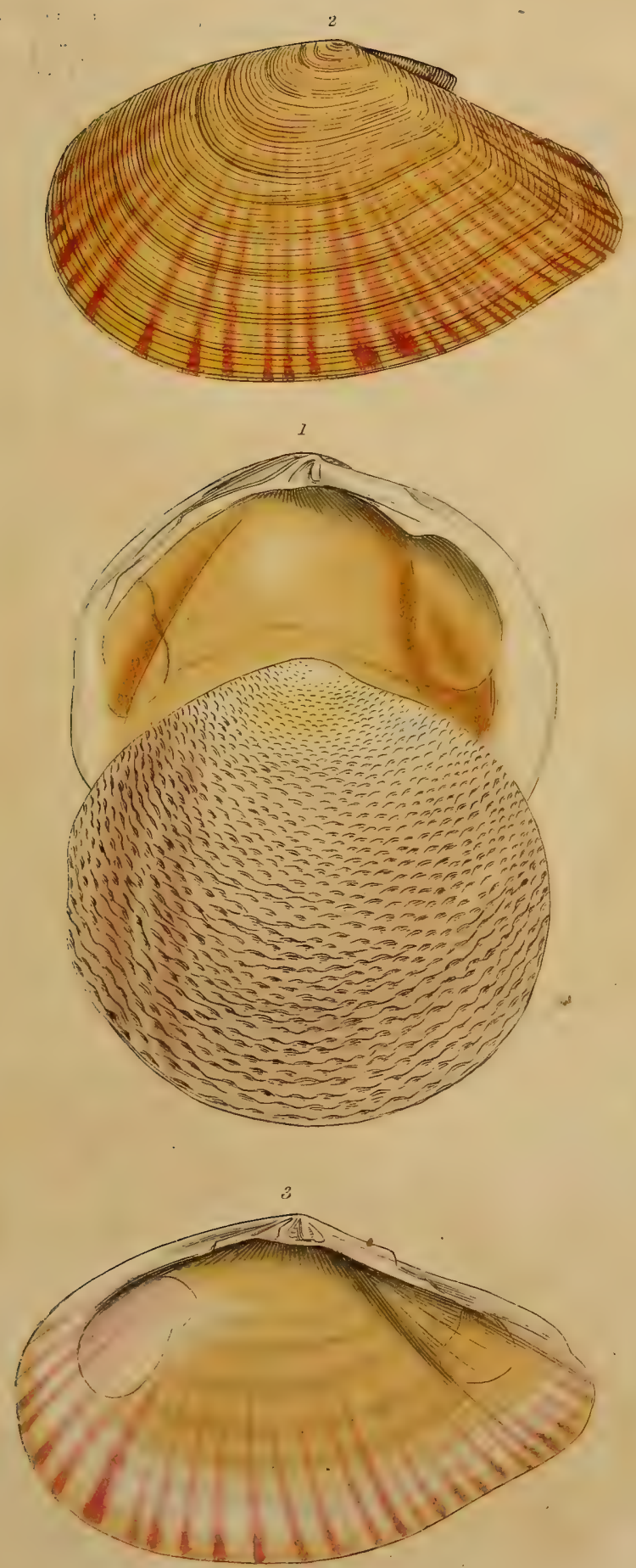

,

(and

..

$\therefore$ 
v., 30.

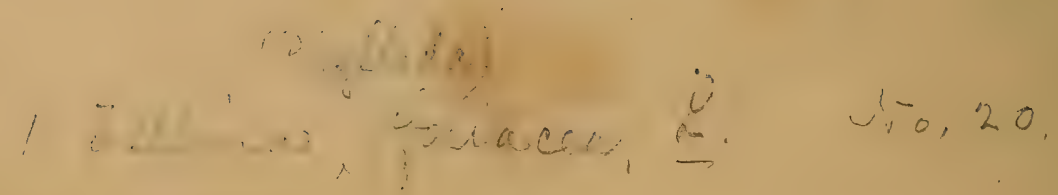

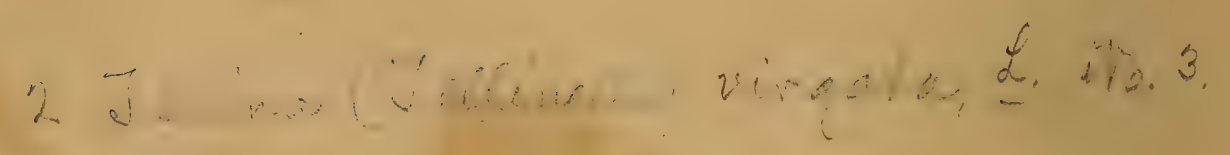

$3 \quad$ " intermect" thace tint

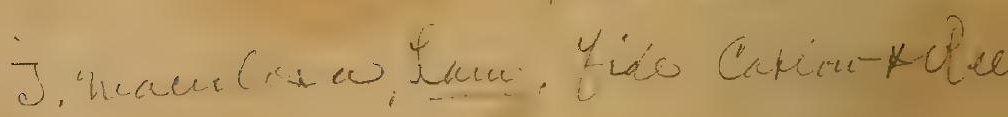



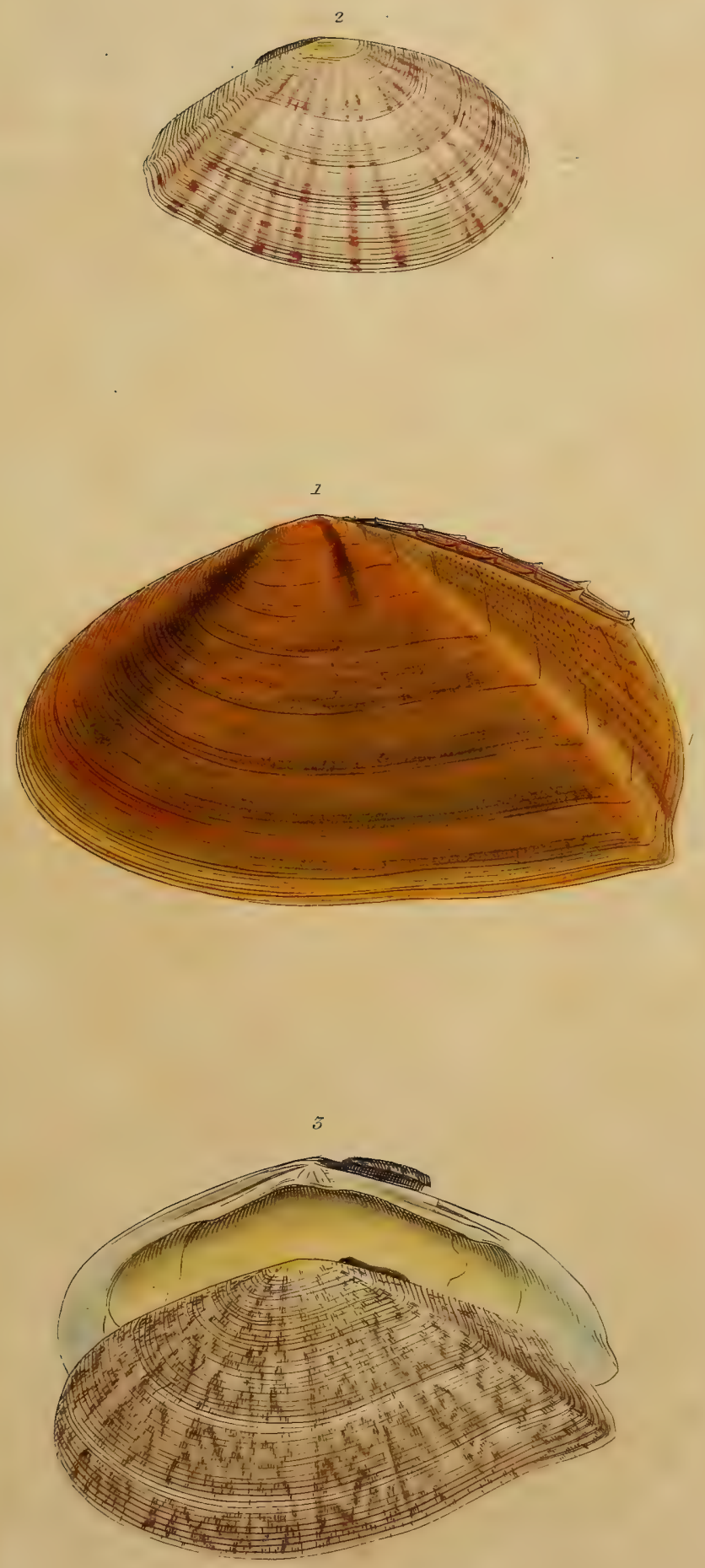




$$
0
$$




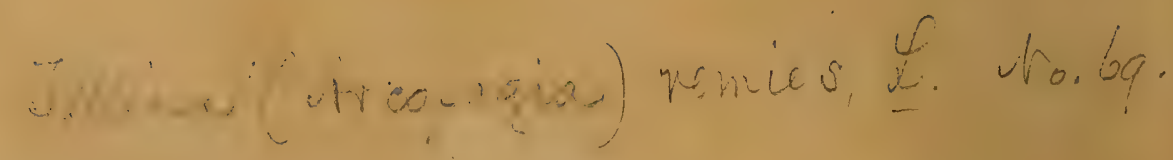

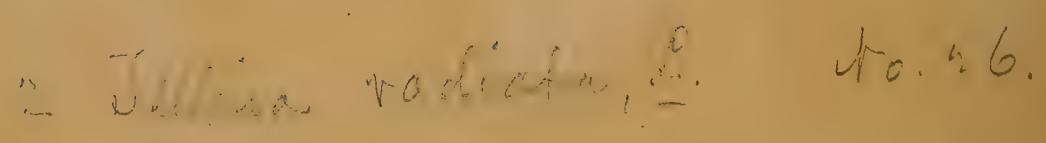

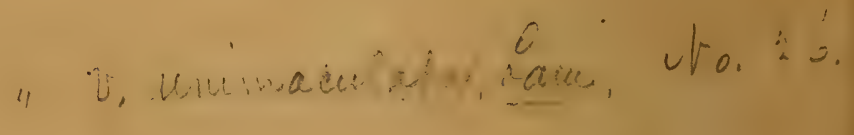



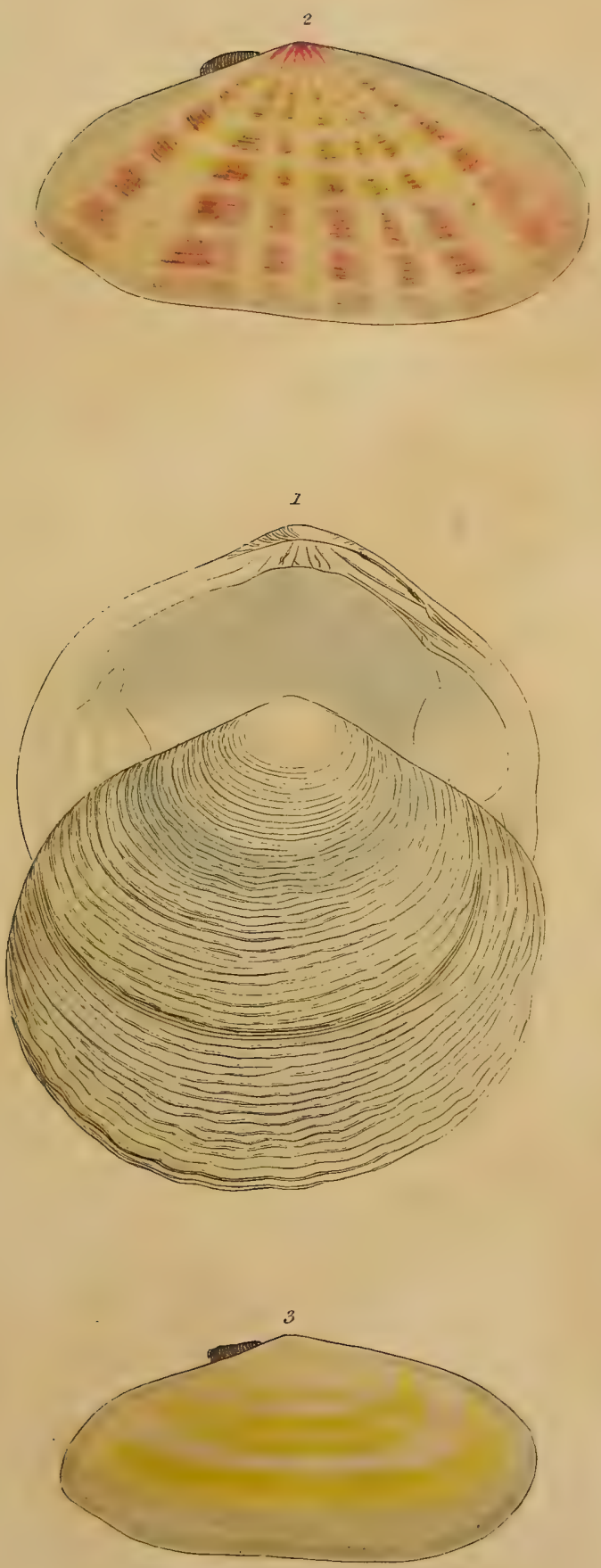


v.t. 36

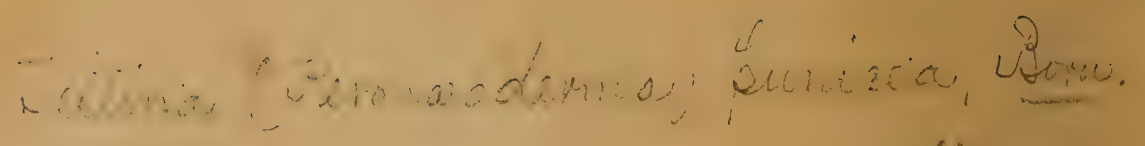
Uio. Ln

Sa..., 2 i

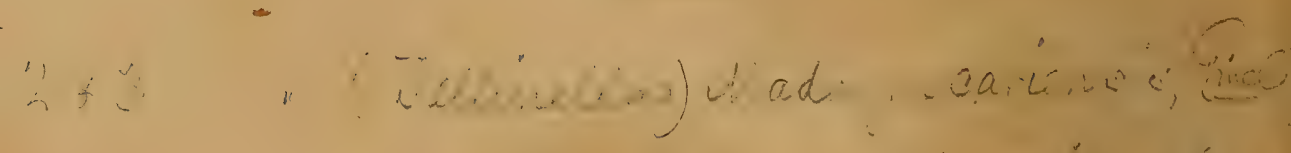

16. $4:$

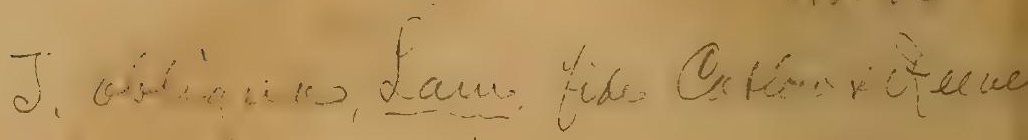



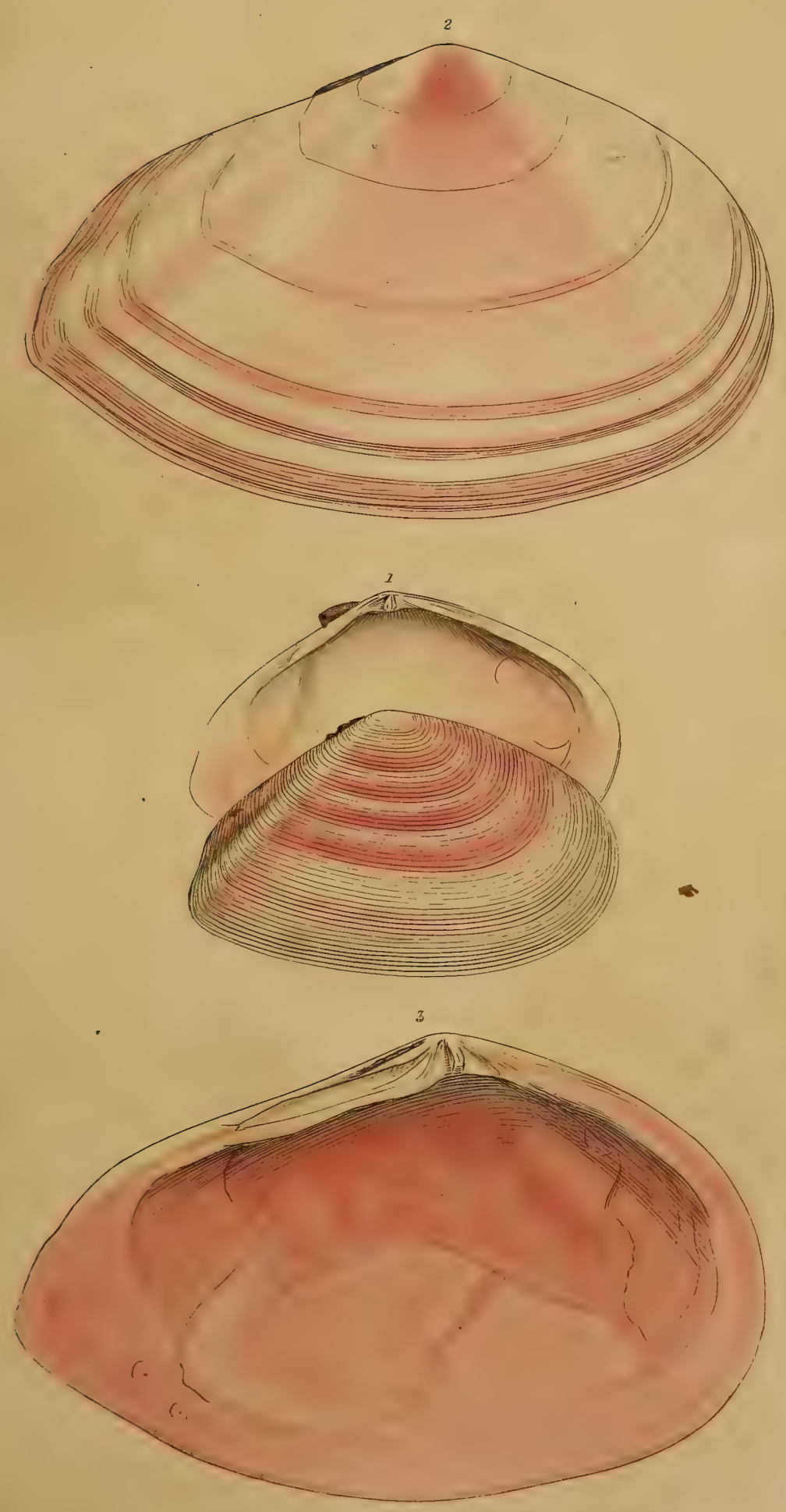



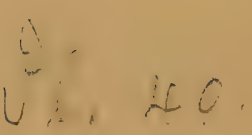

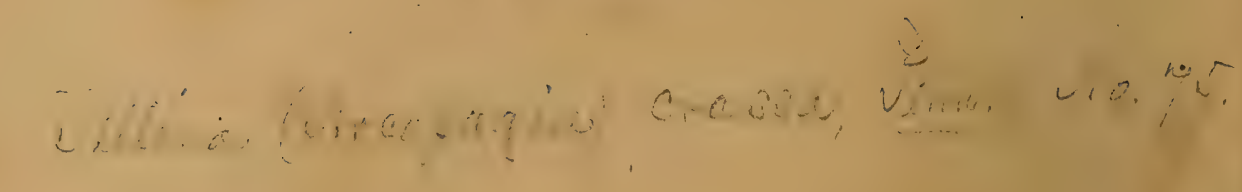

$$
\begin{aligned}
& 430 \text { " }
\end{aligned}
$$

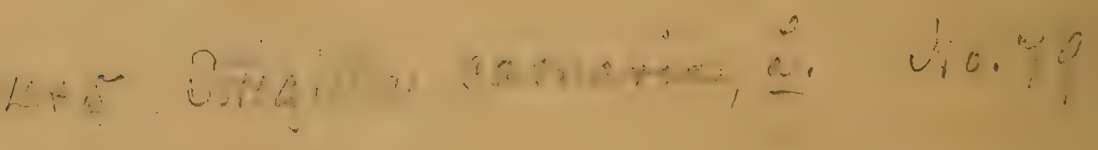



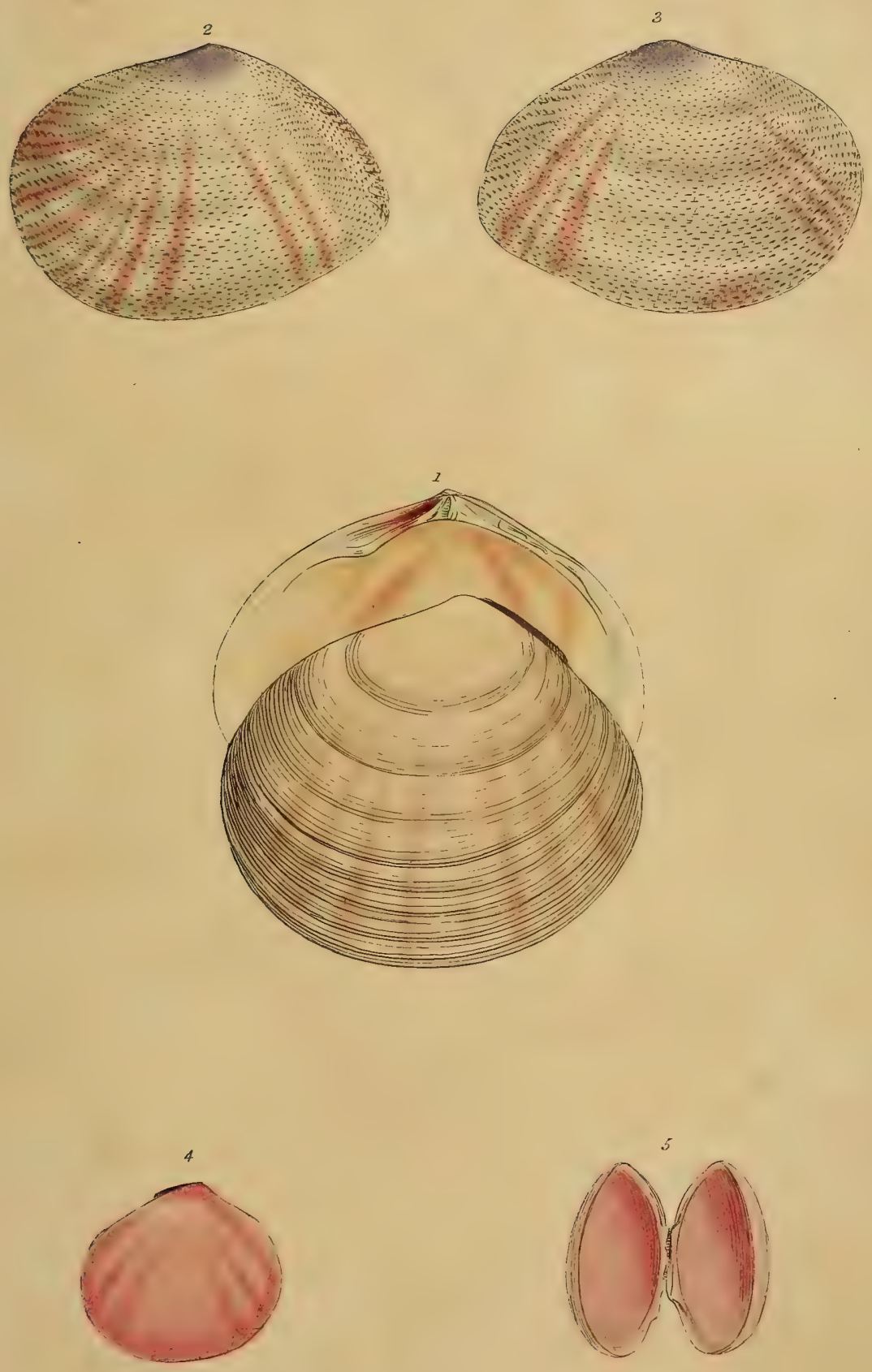



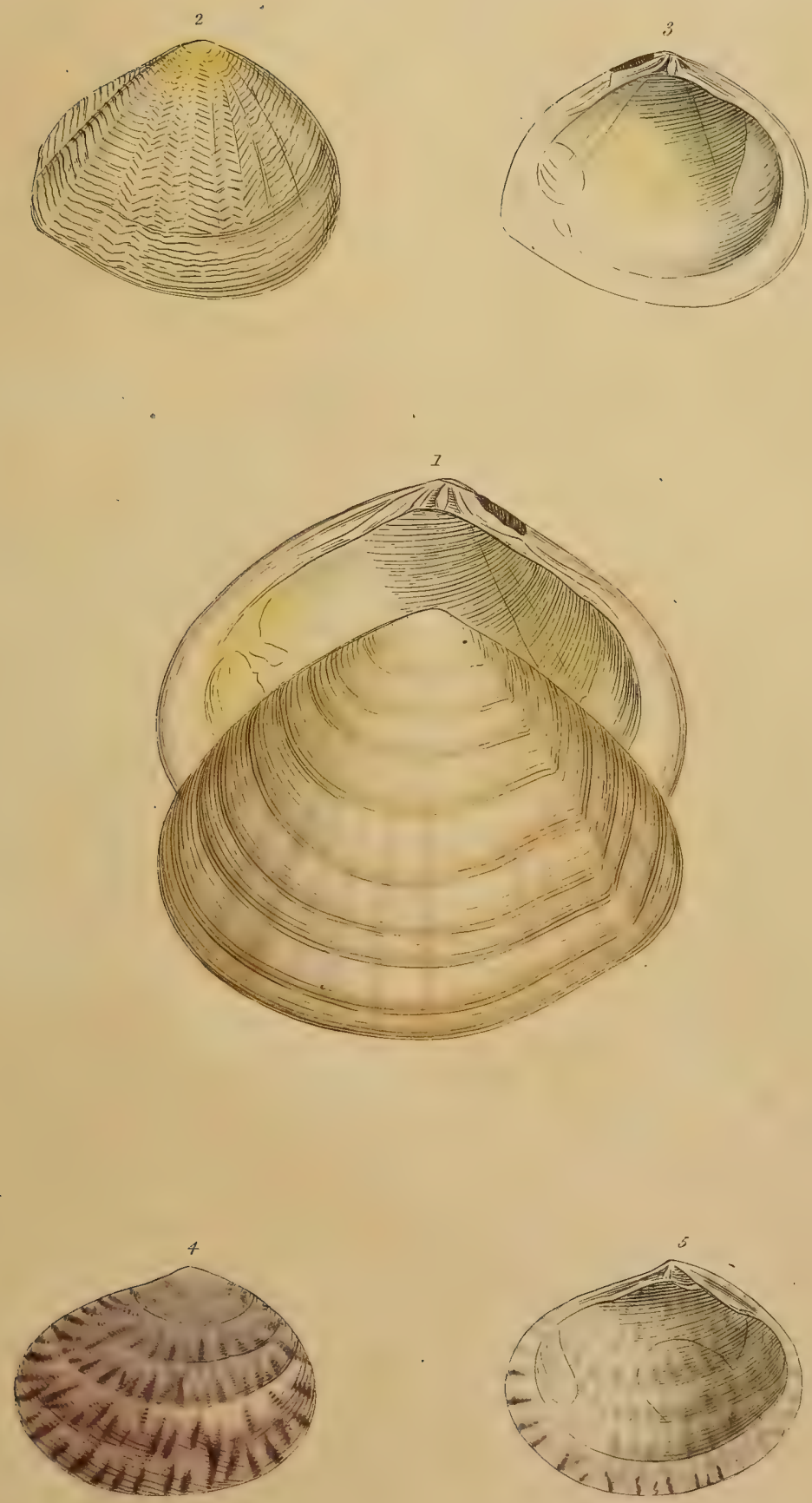



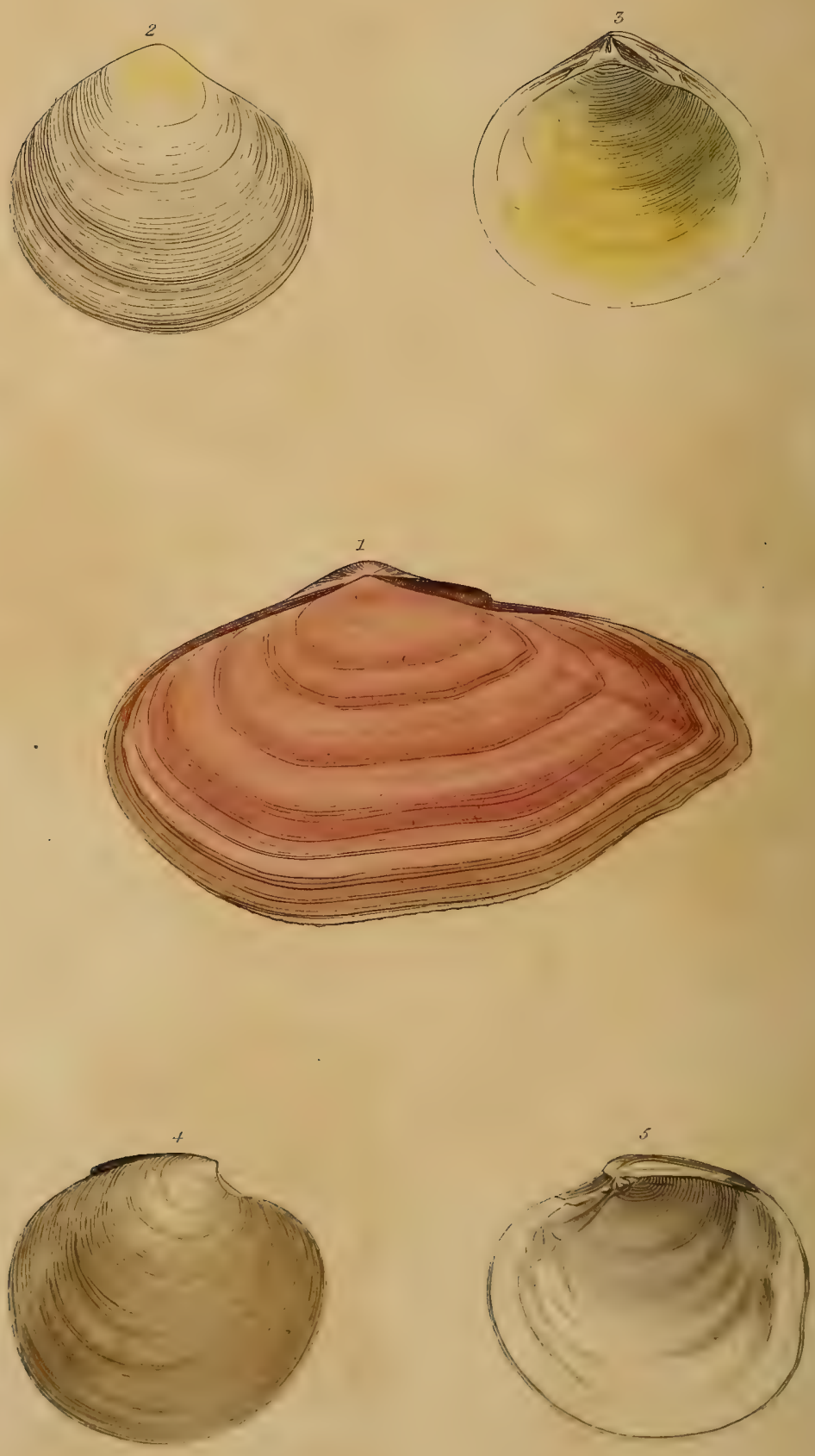




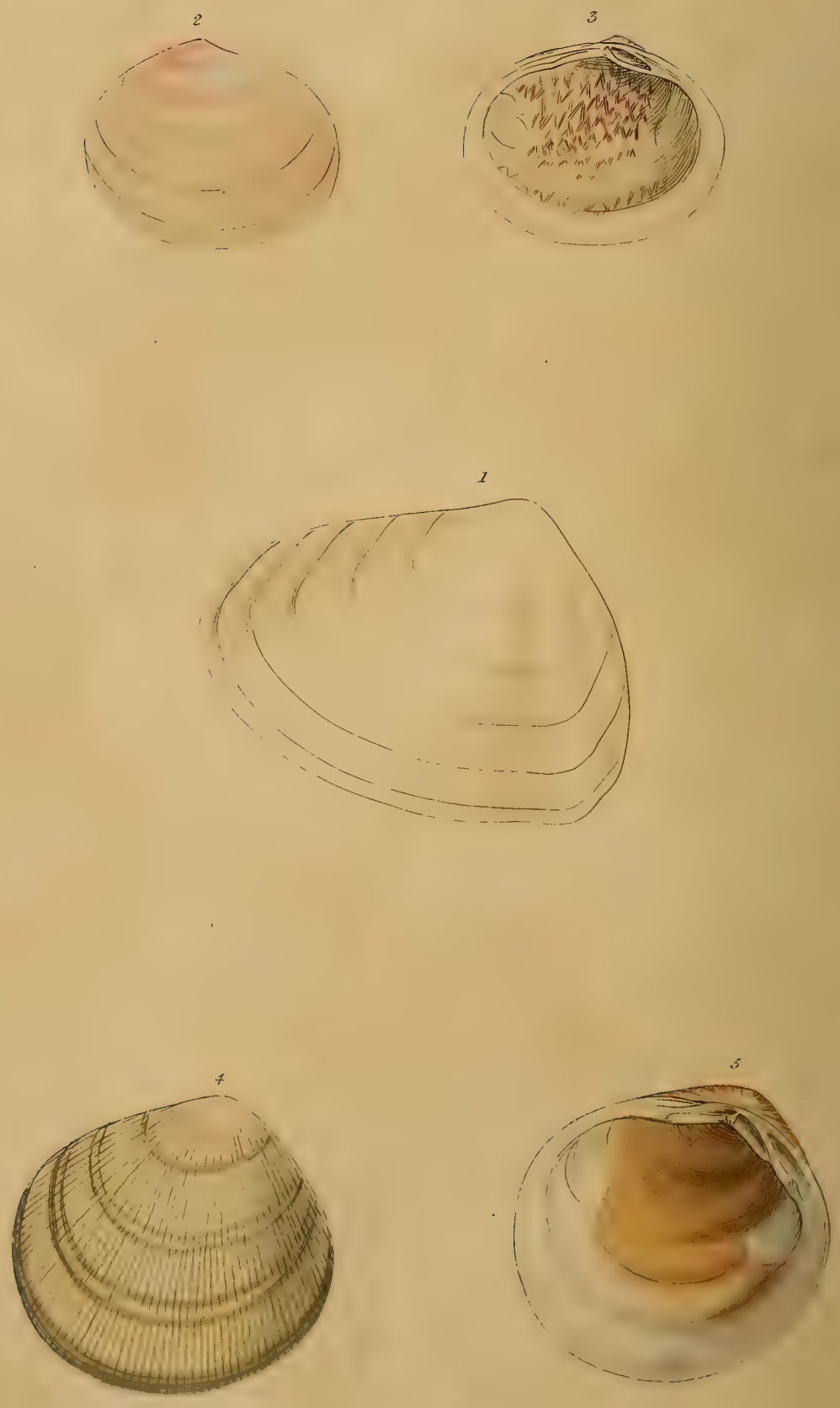
.

.

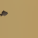

-. 


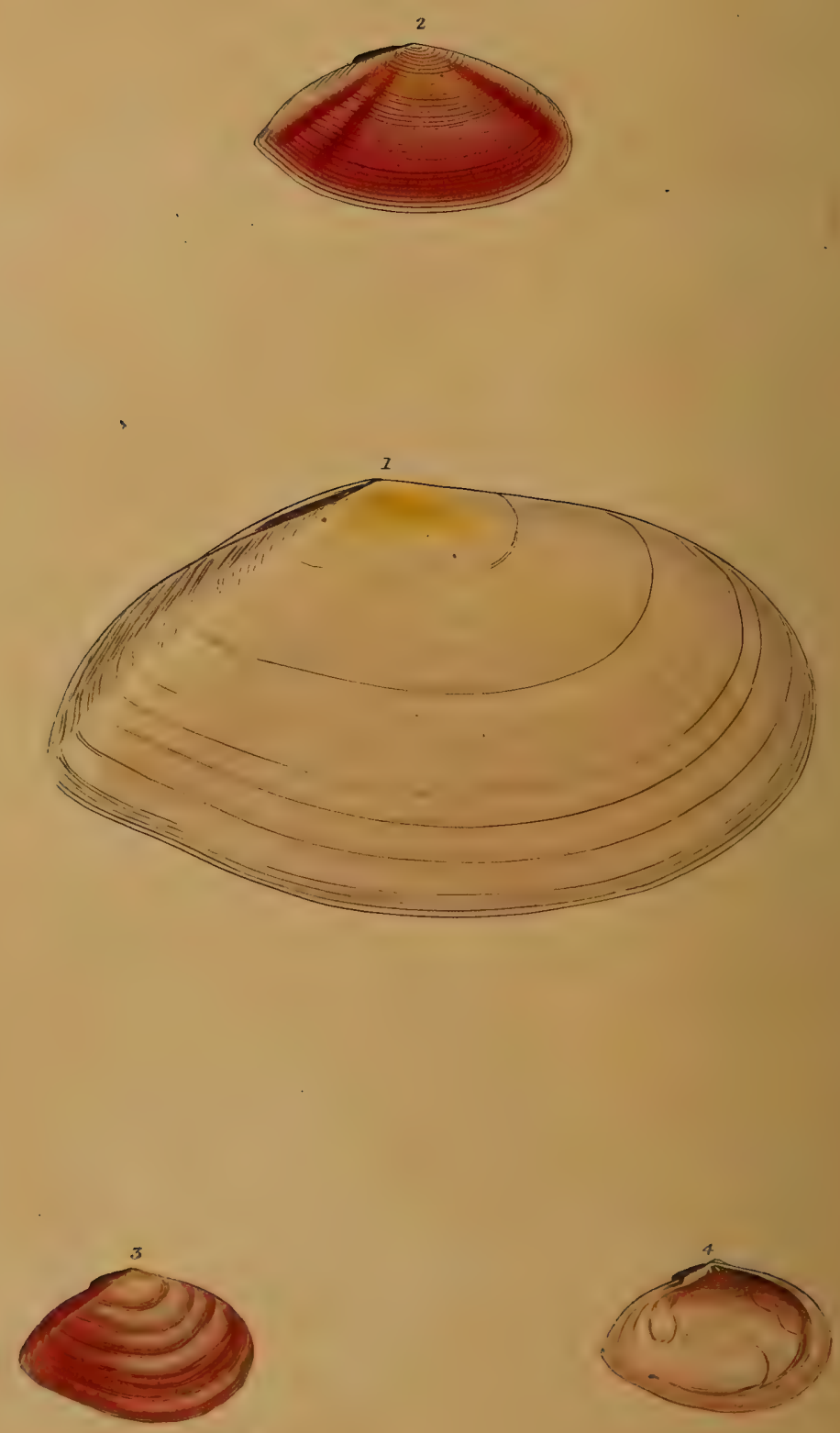



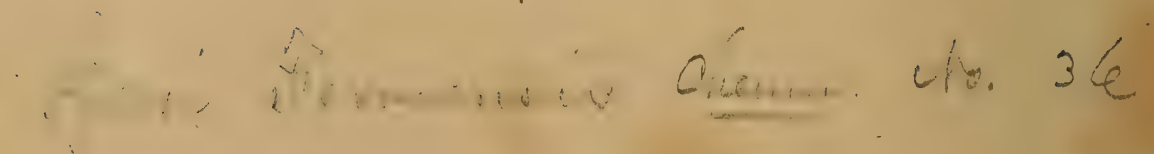

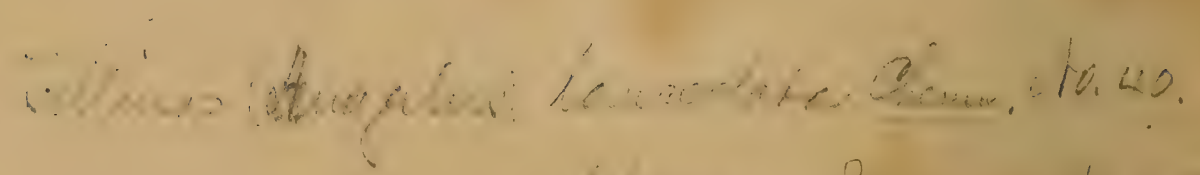

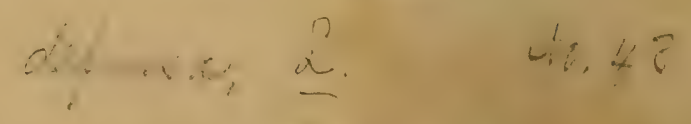

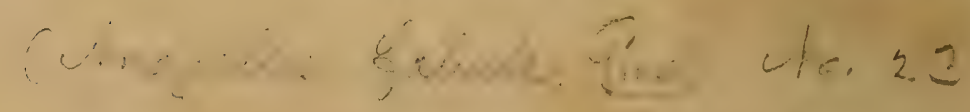

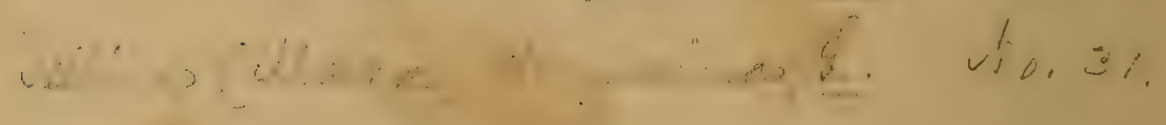

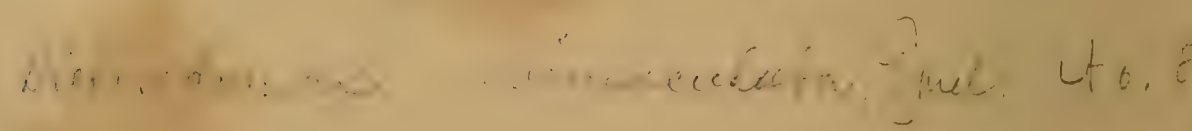



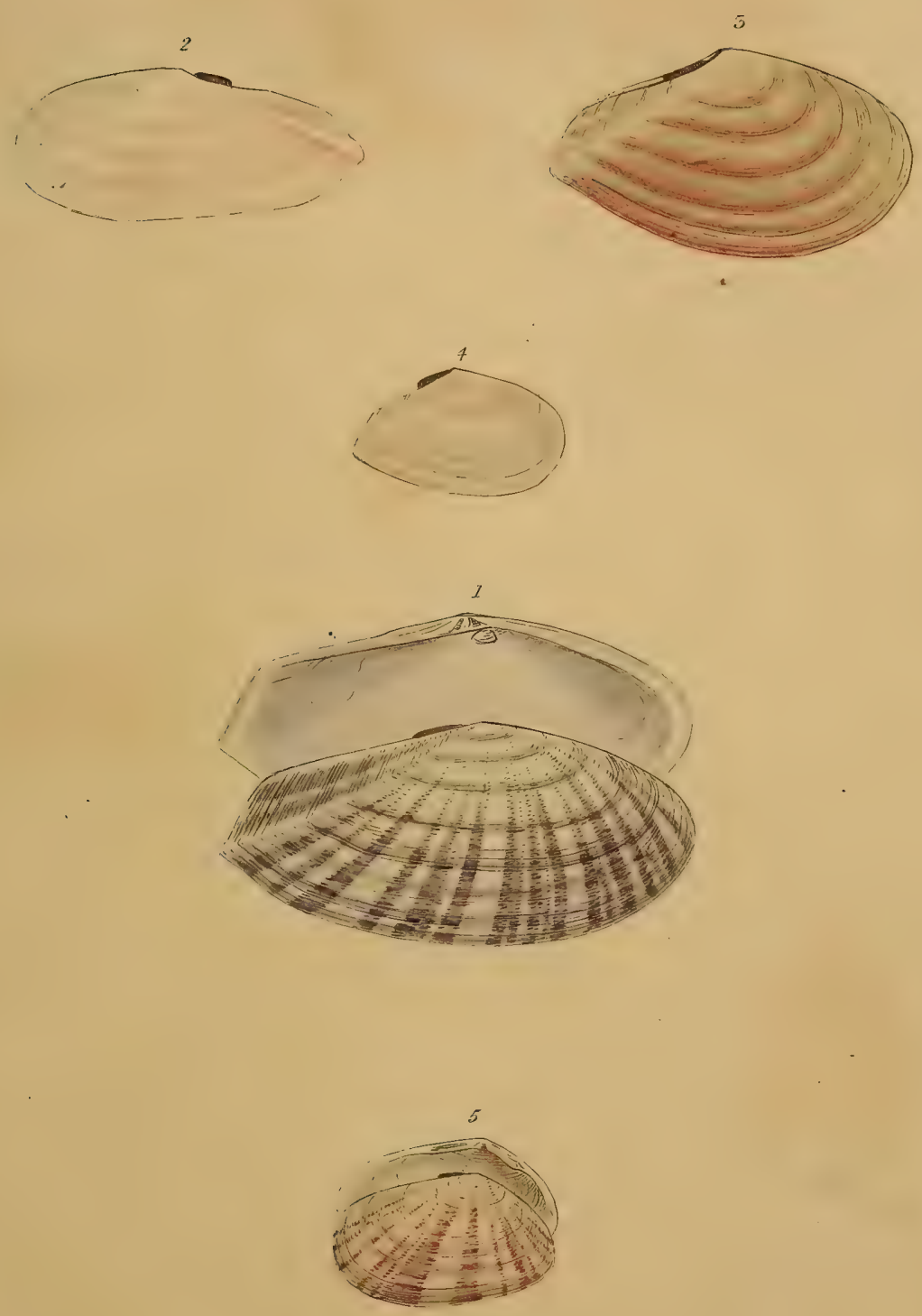

,
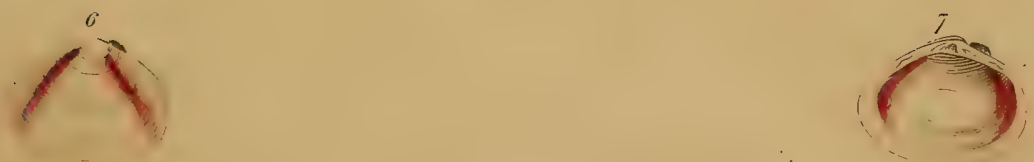



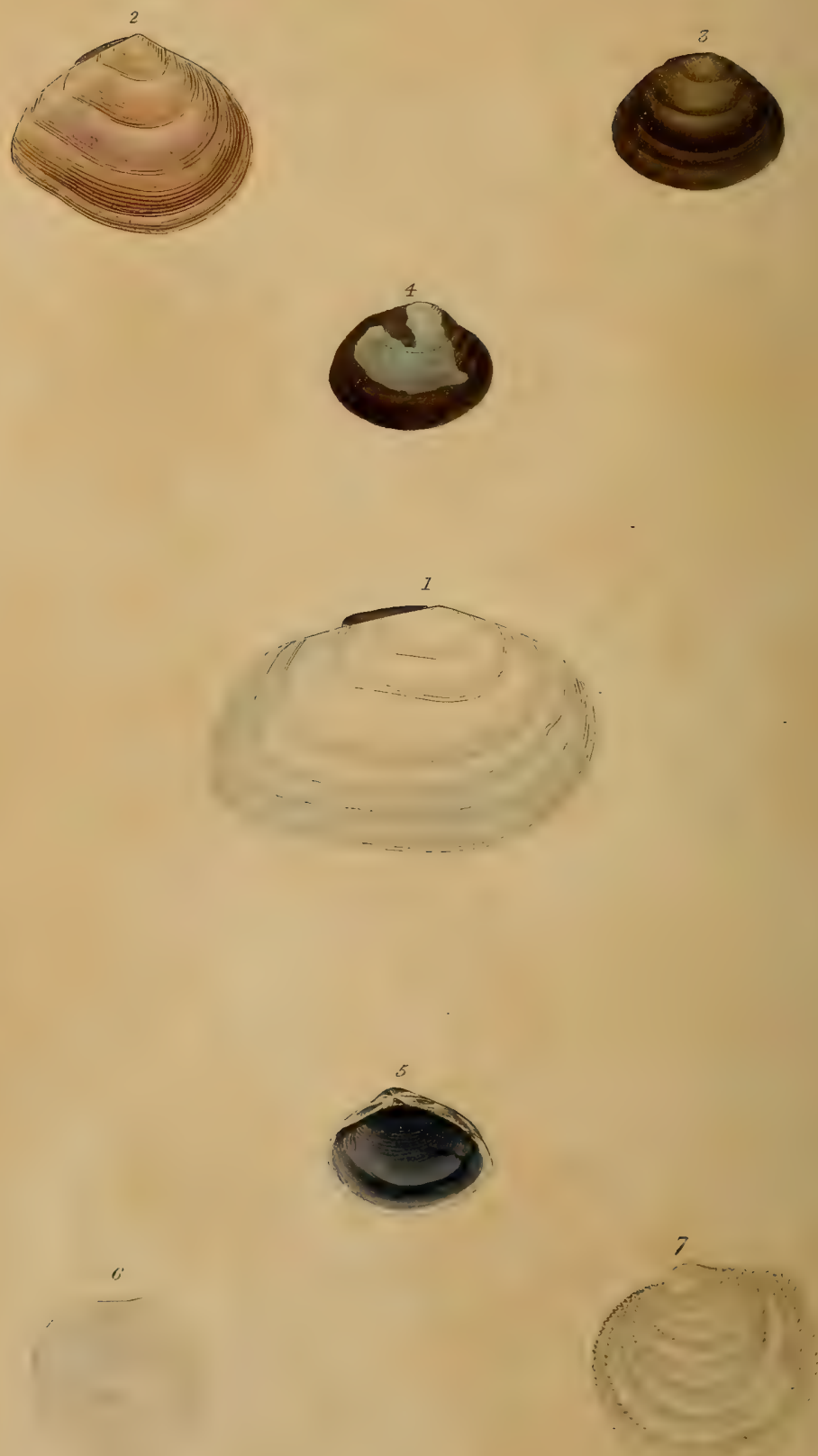


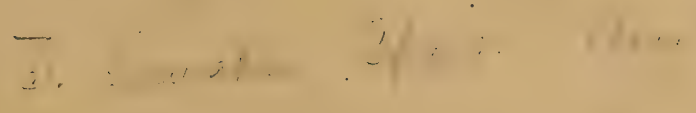





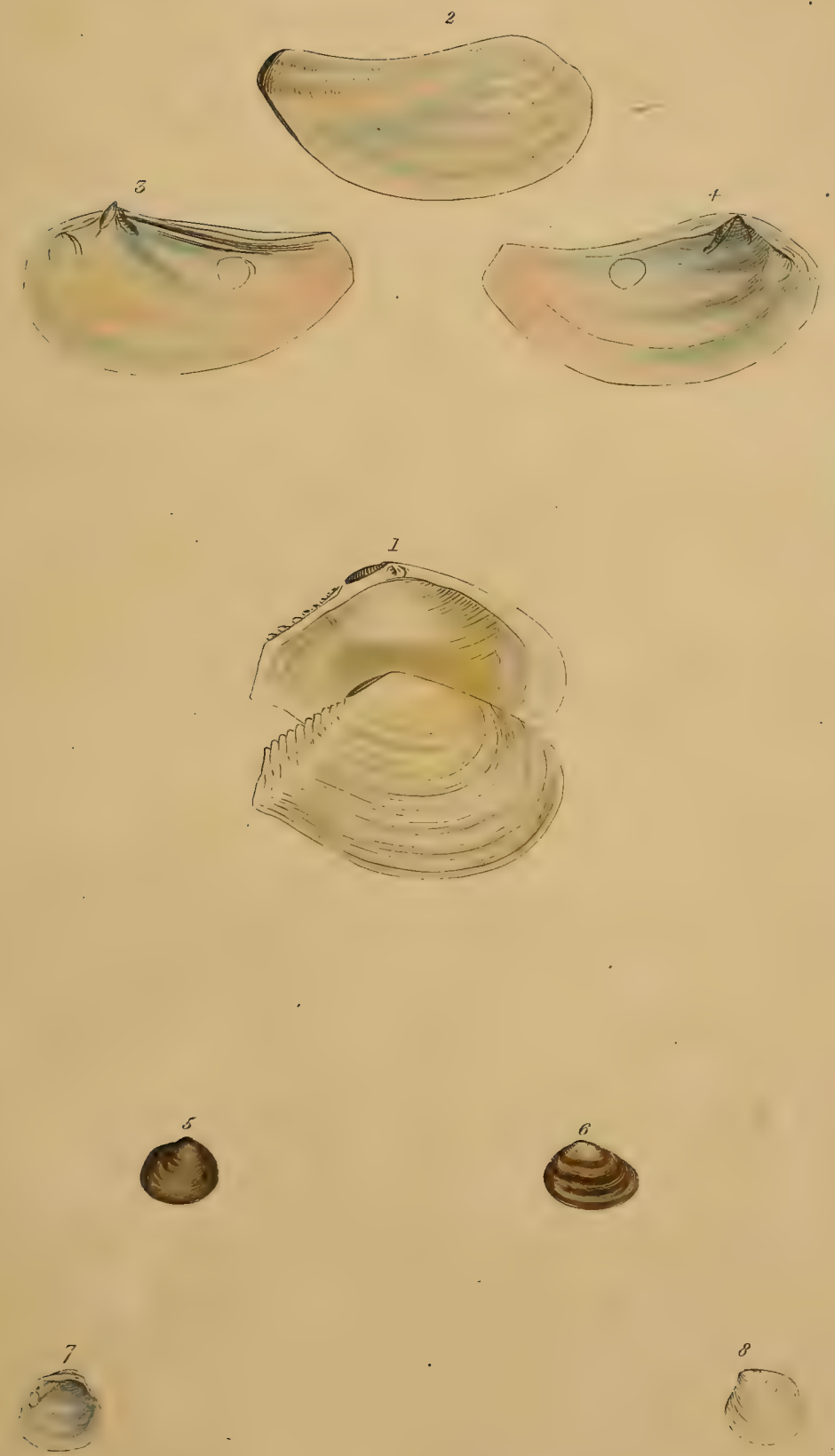




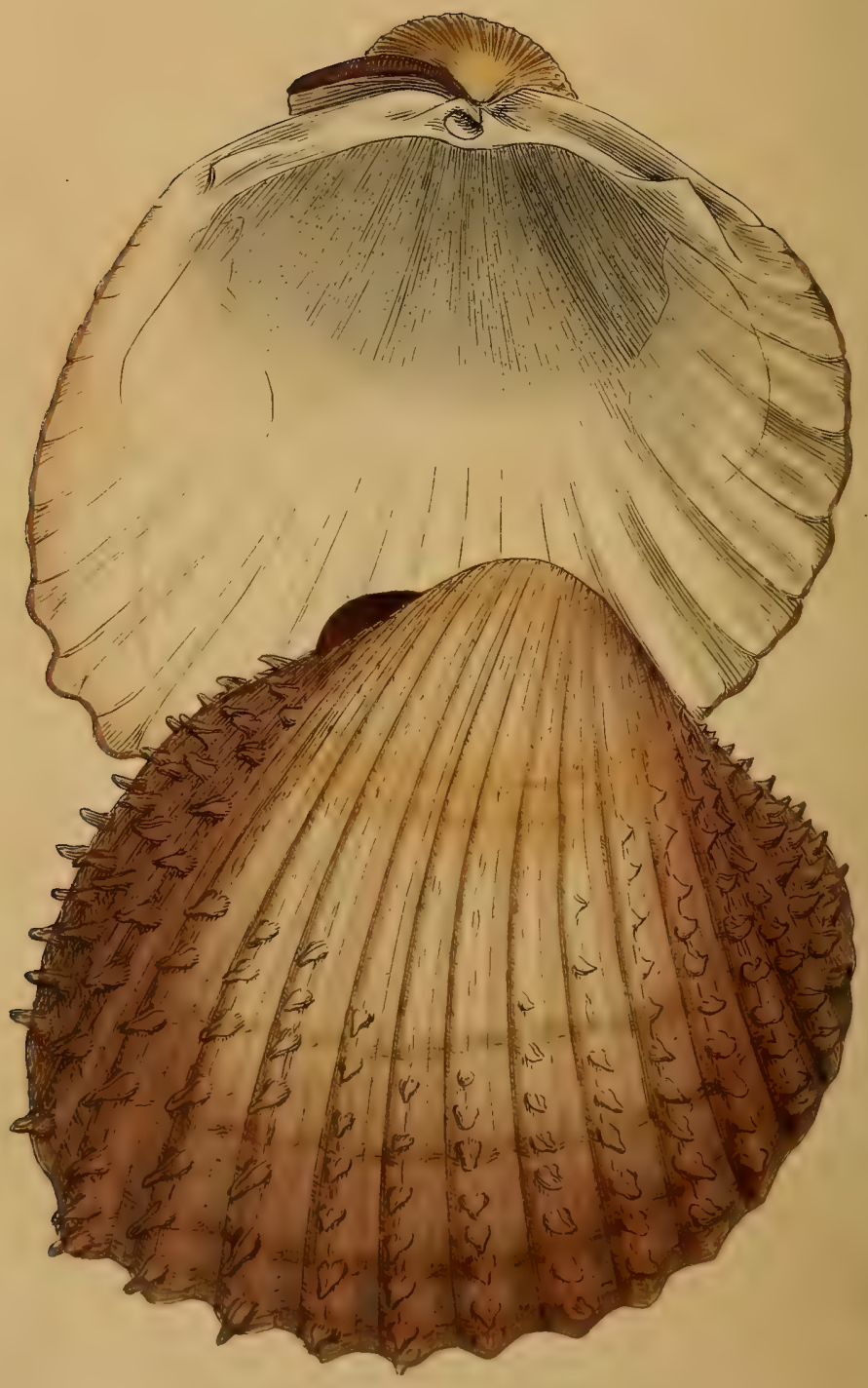





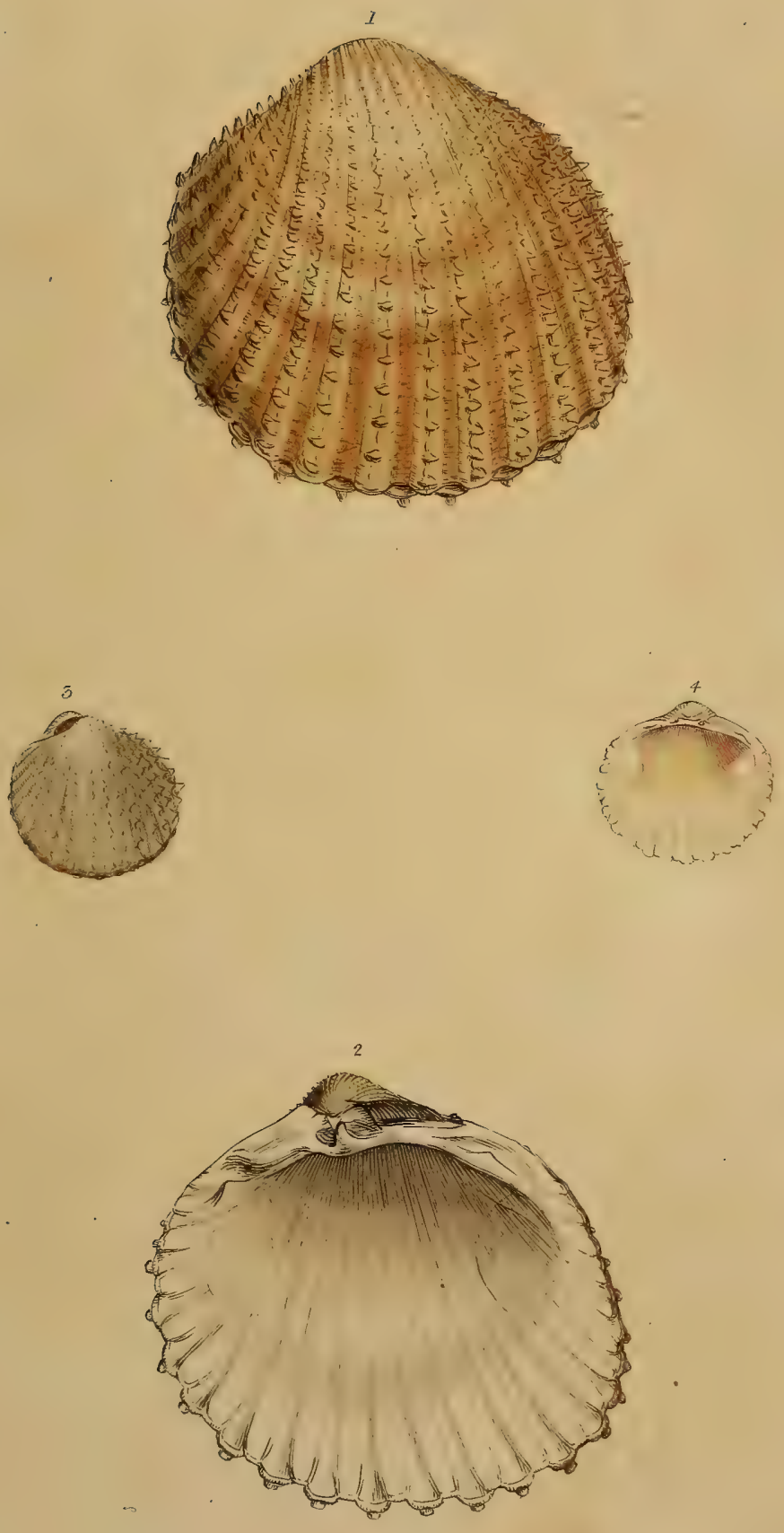


E

$\therefore \quad \therefore+e_{0} \cos$

$\{\quad \sin \quad \underline{\mathcal{L}}$

he. 

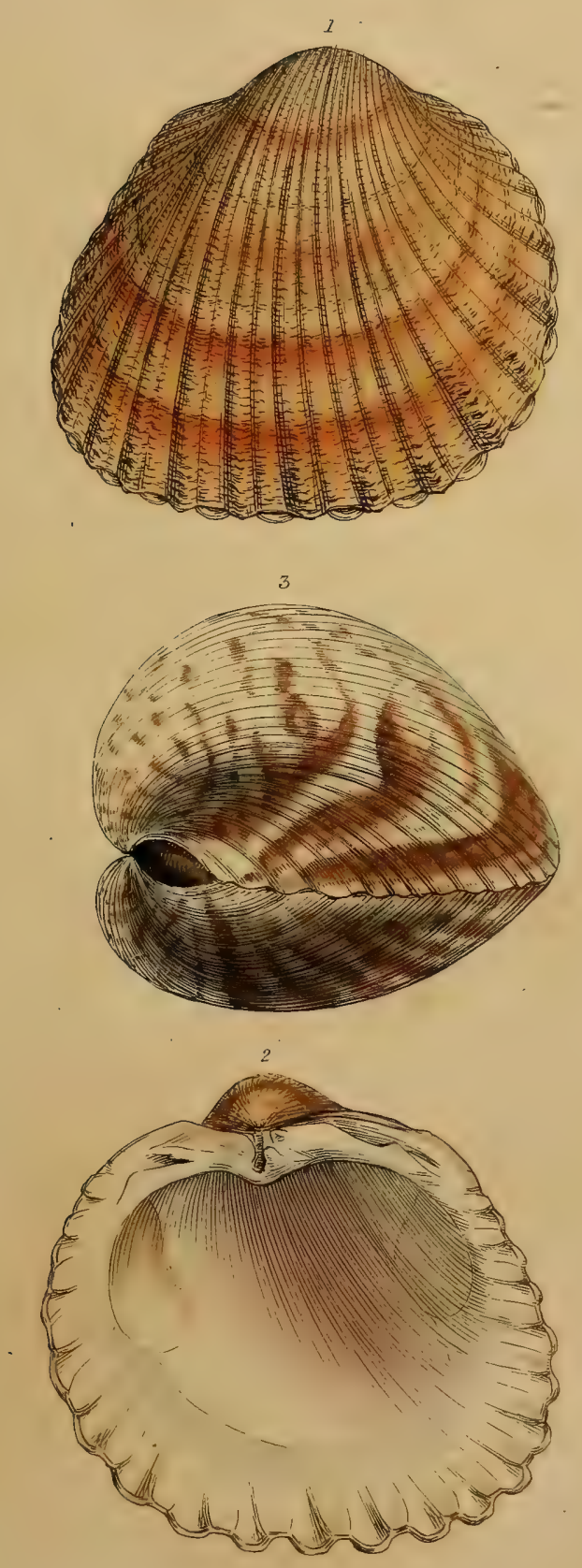



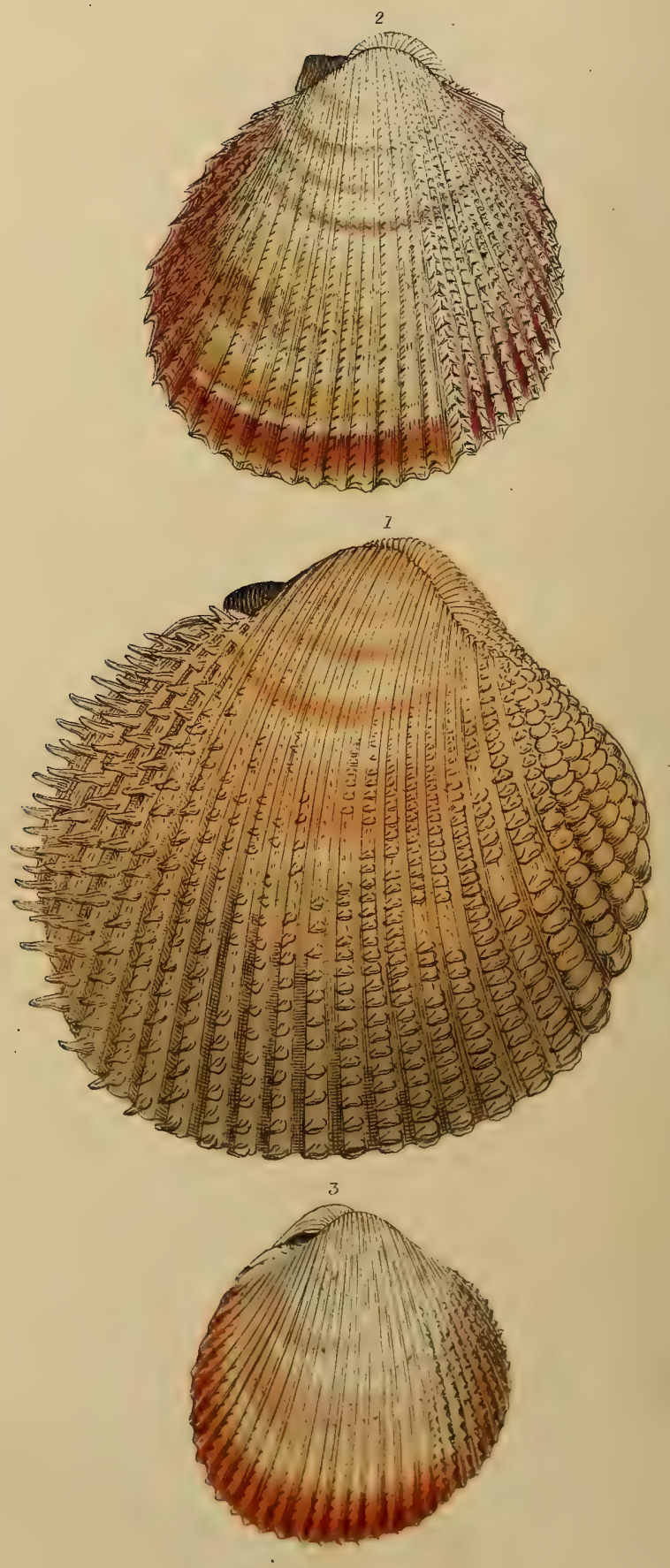

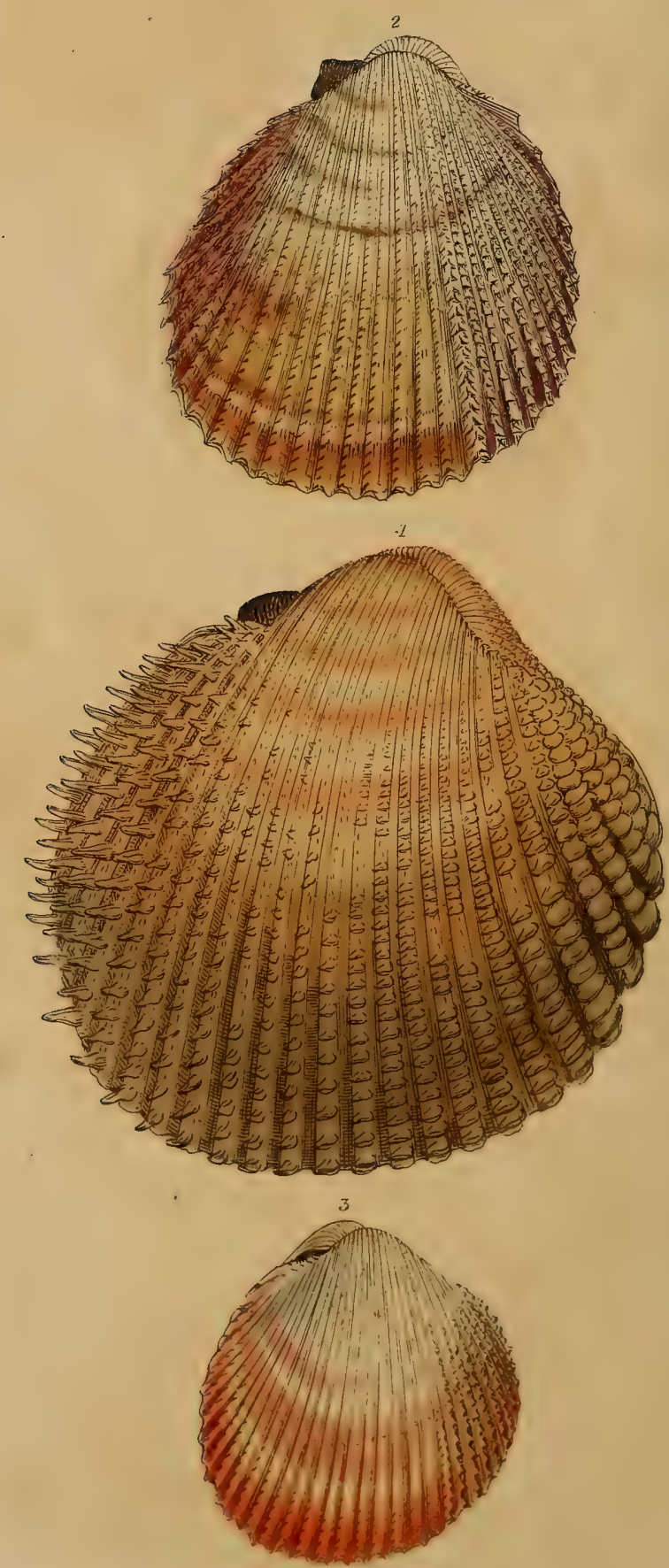
$1 C$ aevbation á.

3.

Th- $=5$ 



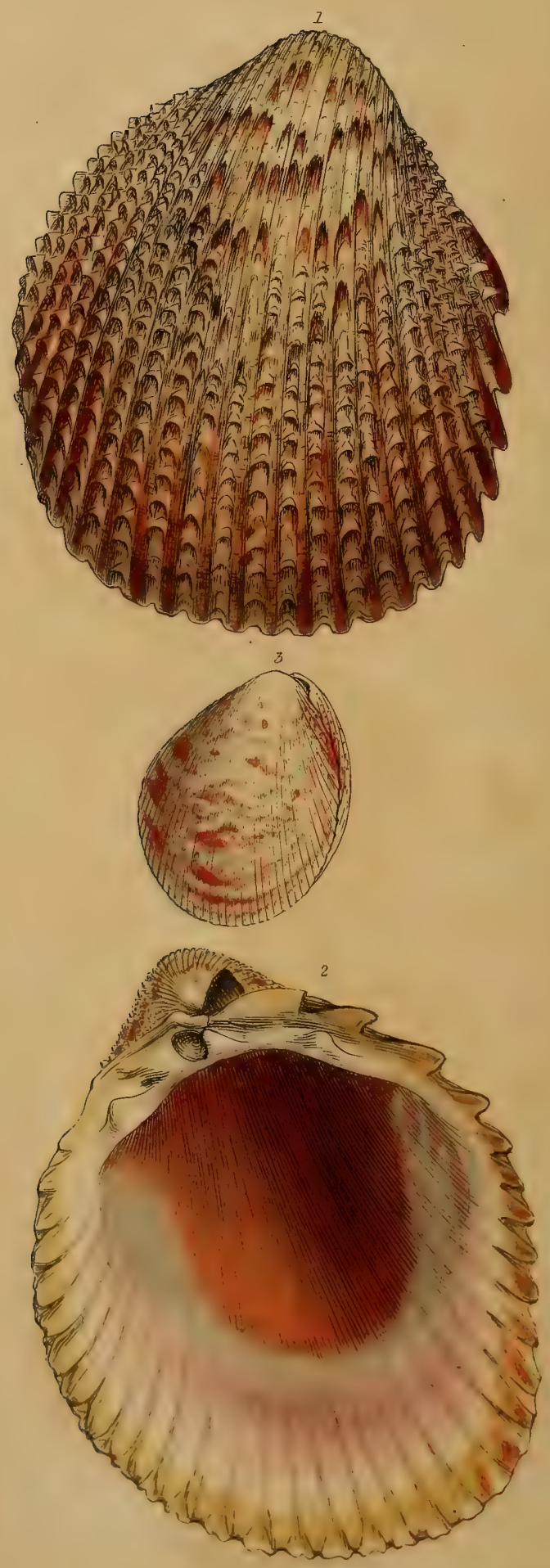
c. Lacestatio b. ins

$3 \&$

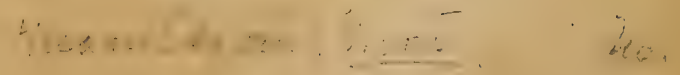
now 6 



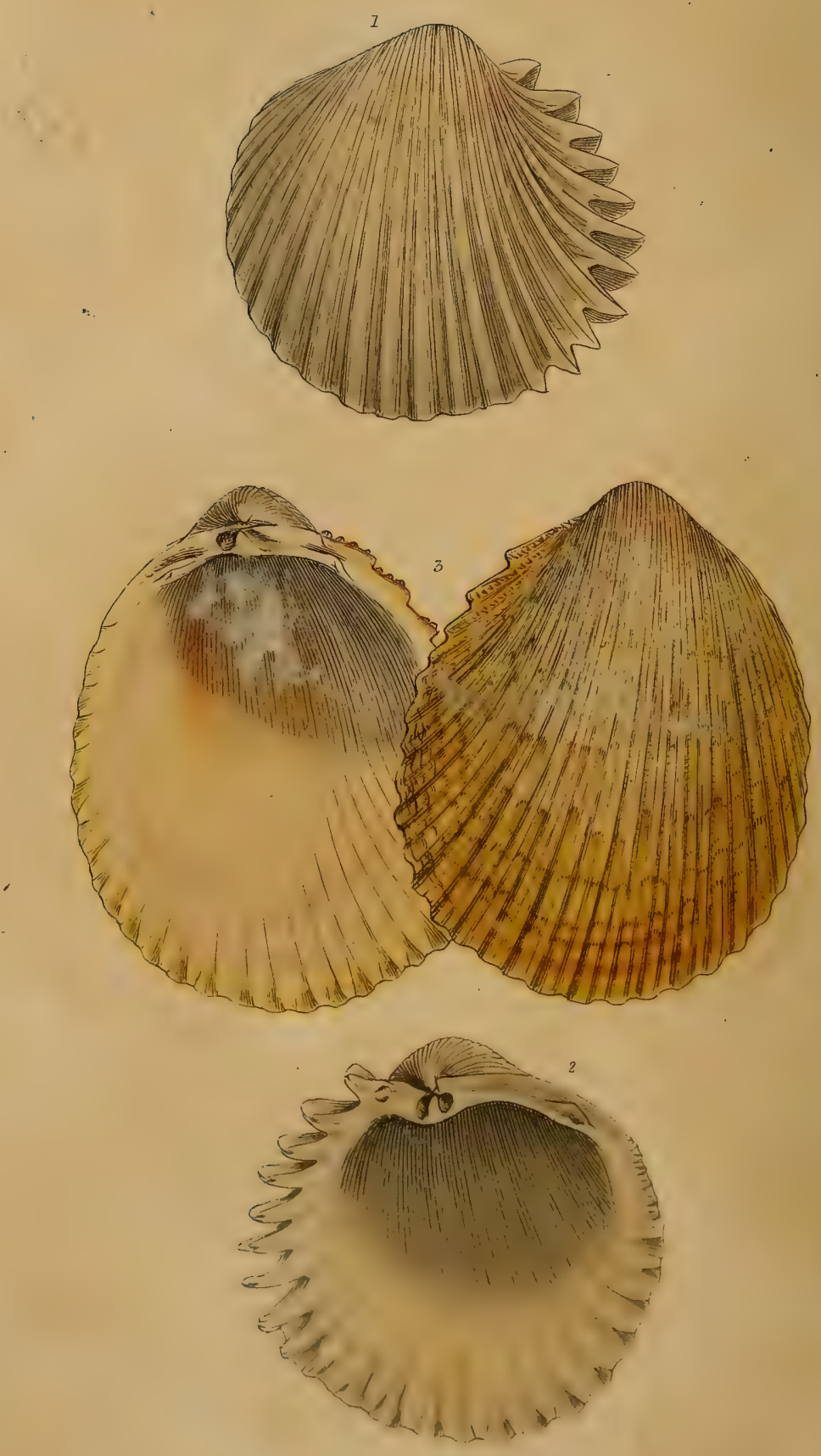


$$
\text { n-1 }
$$

ith ming

cin.1/?

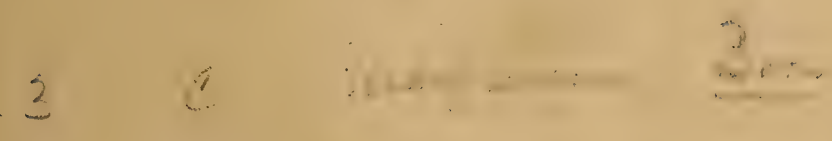

46.2.

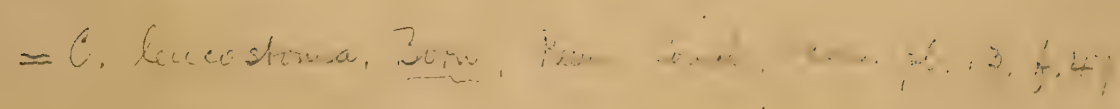




$\therefore$
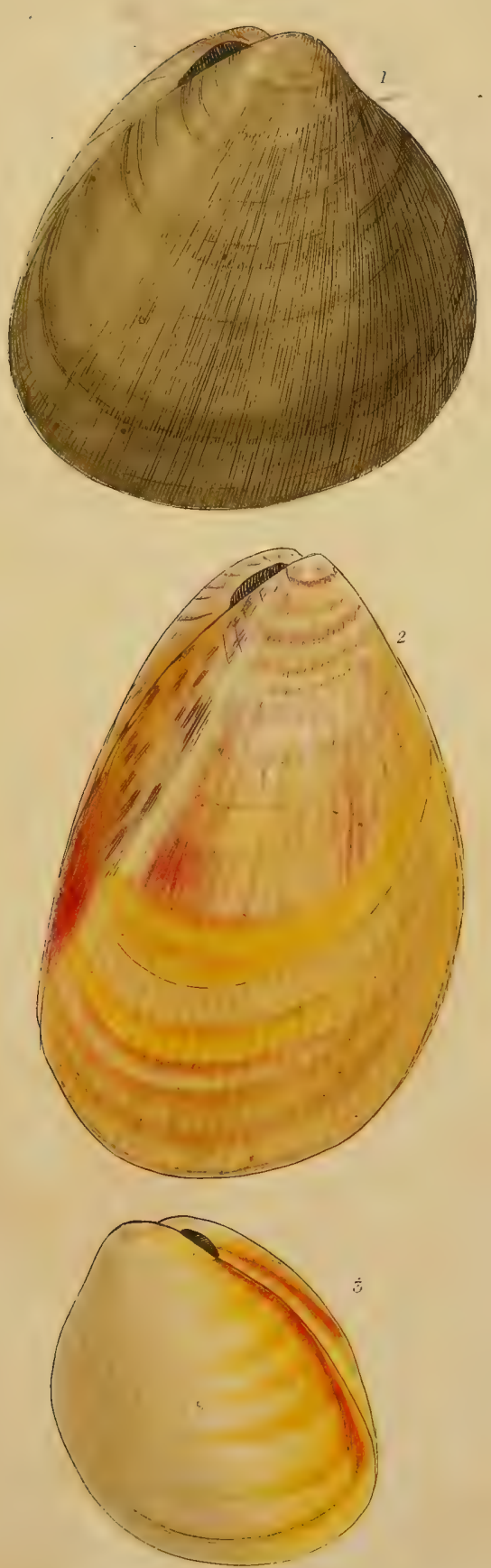



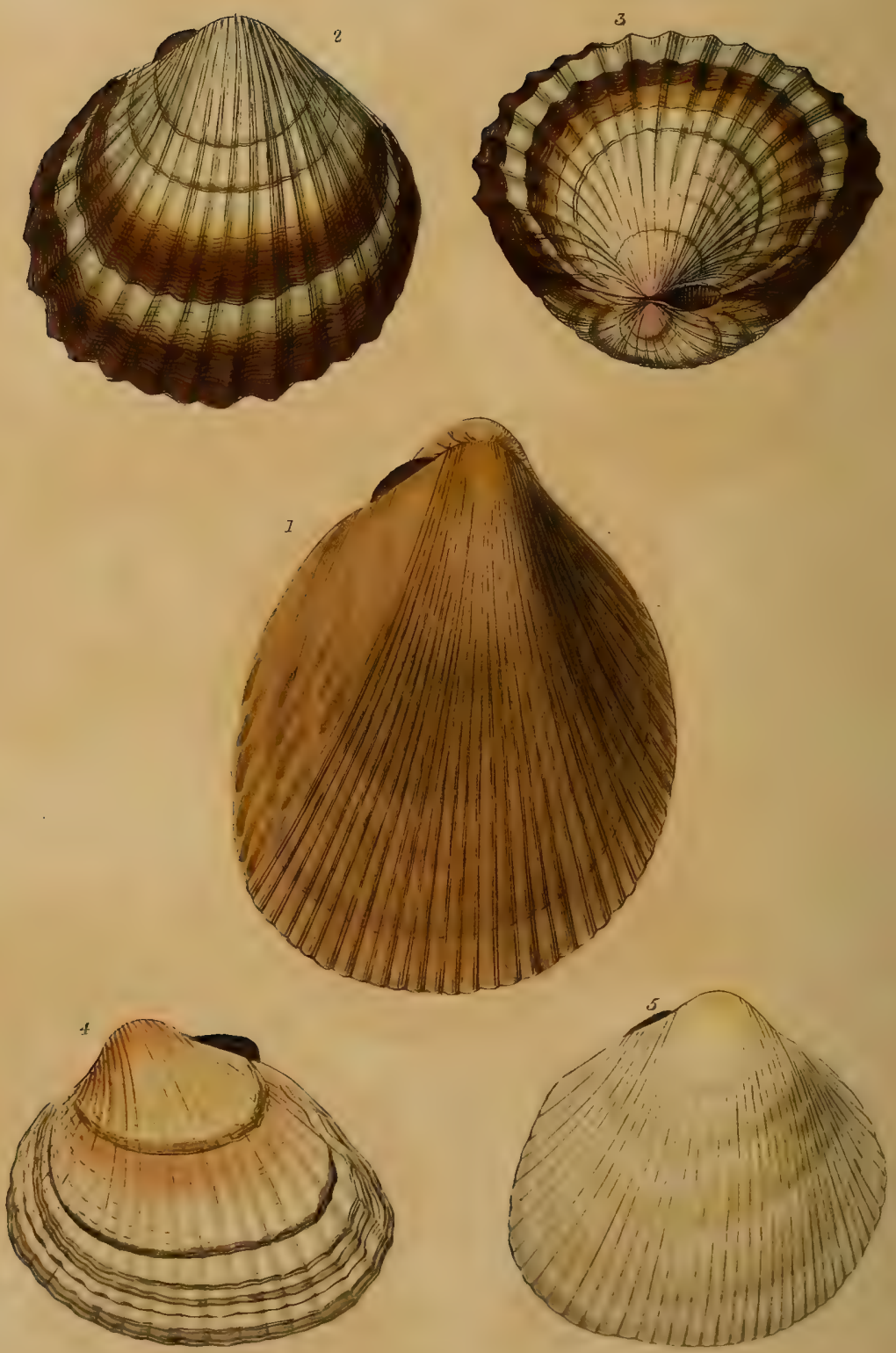


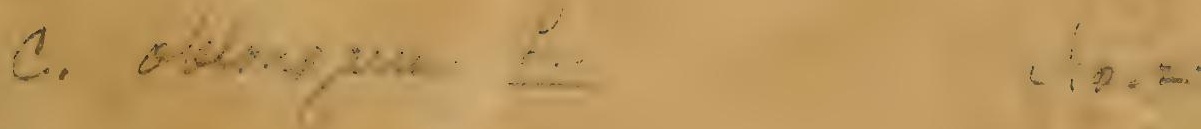

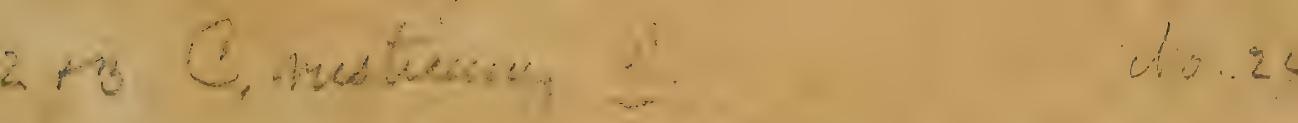

$4 \quad c .25$

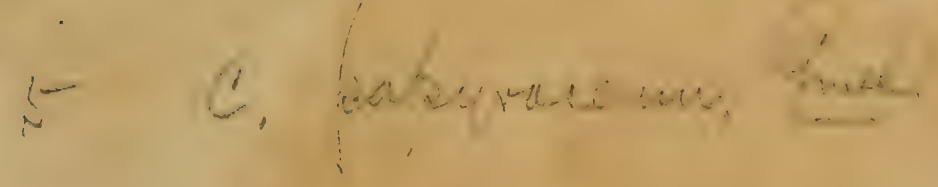




CAIRIDIUNI

ZPIT。
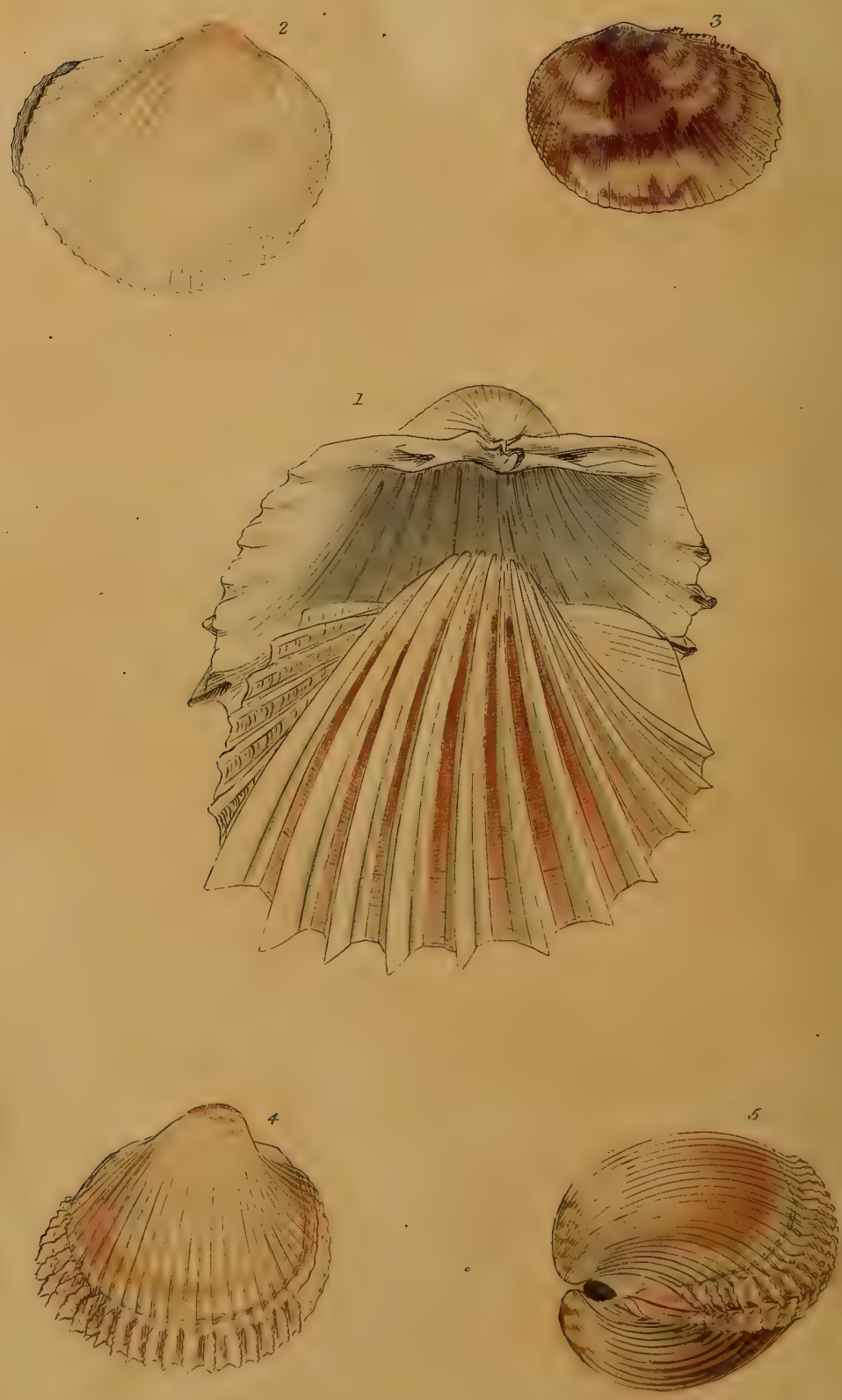



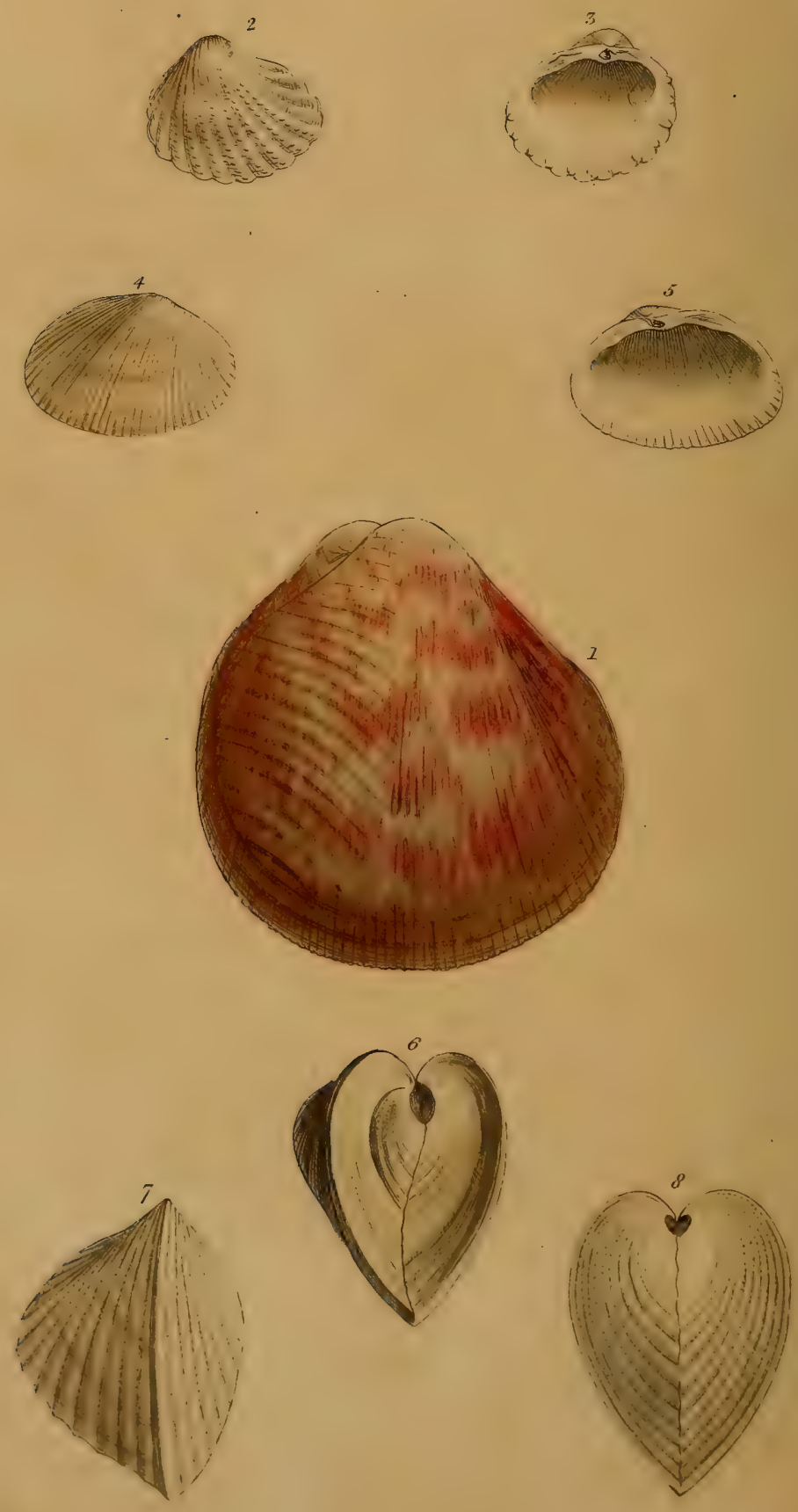


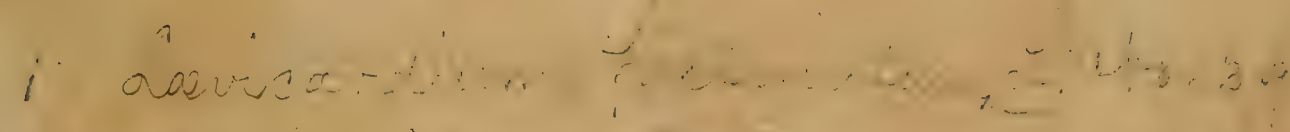

$$
\begin{aligned}
& 2 \times 3 c \text { rigiface } \\
& 4 \div+1 \text {. euram }
\end{aligned}
$$





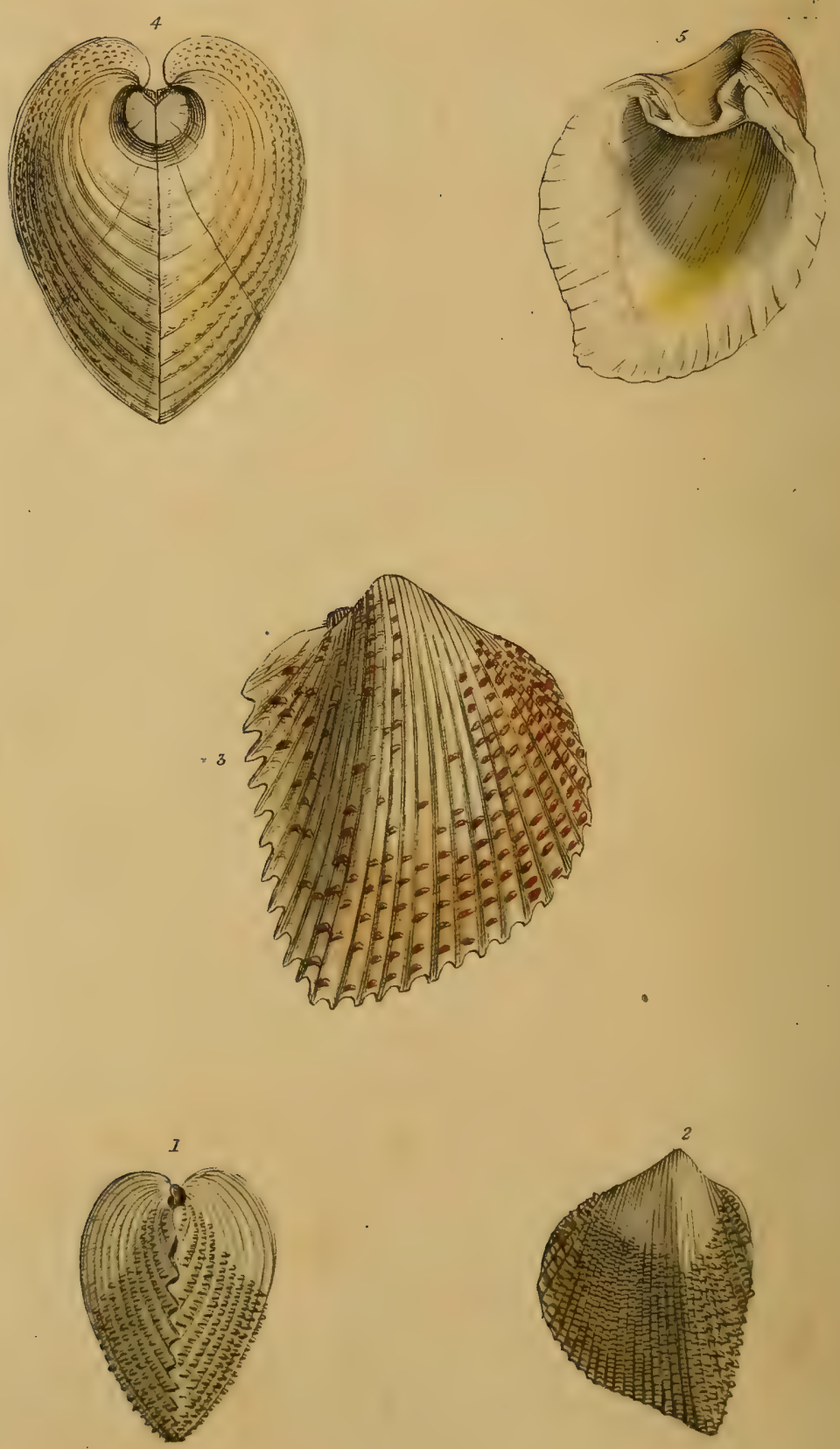


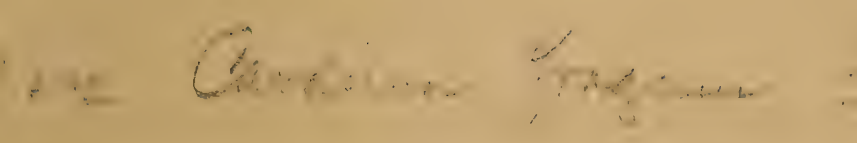

$\eta_{10} .90$

3 $10 w \times 0, \ldots$

4,5

Whe wer, 2 


$5 \%$

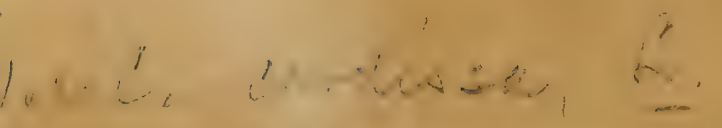

112.53

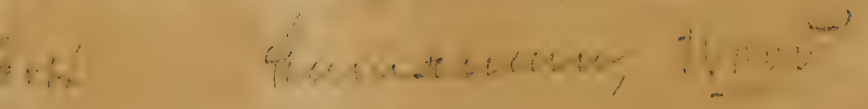

.5 

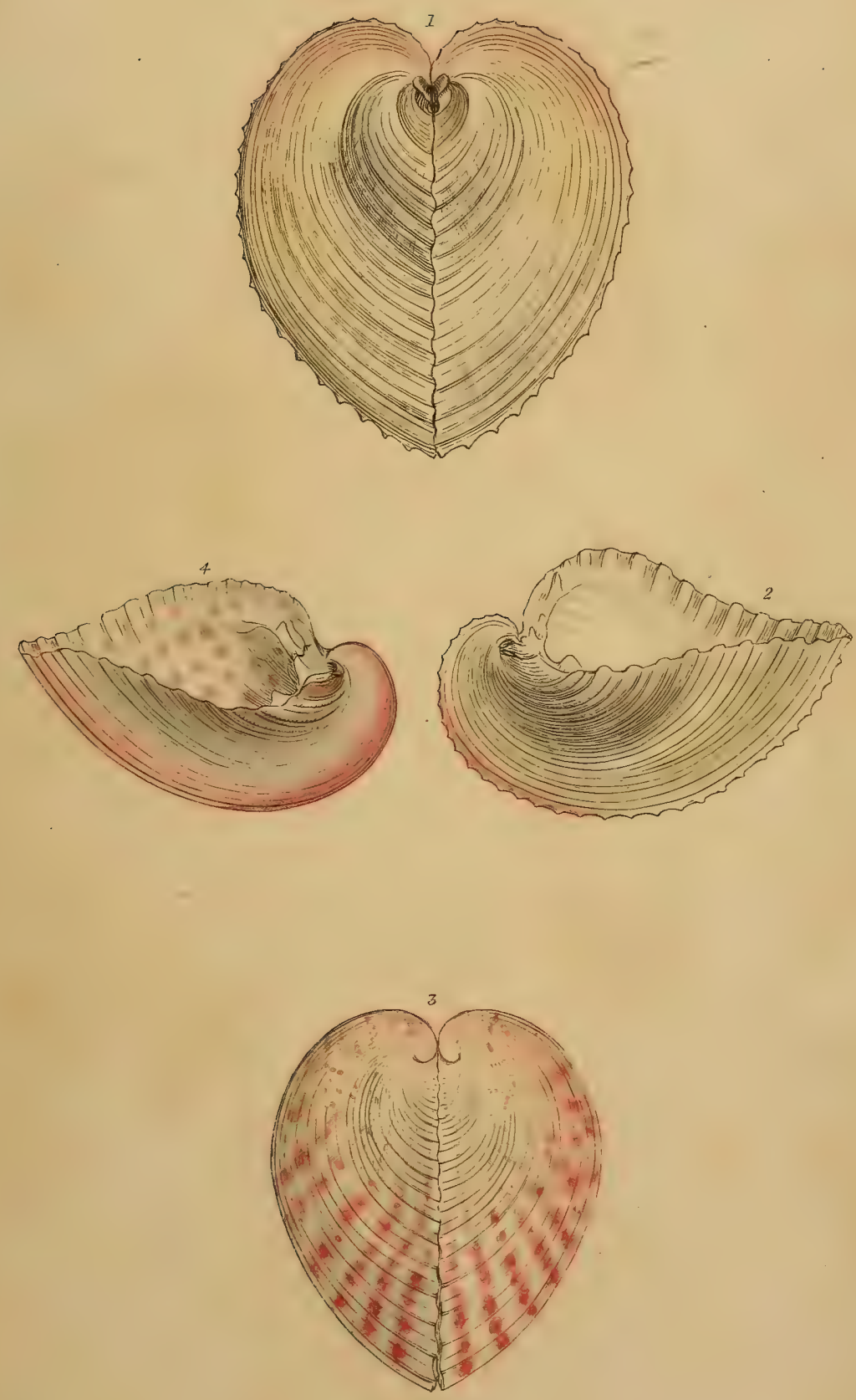







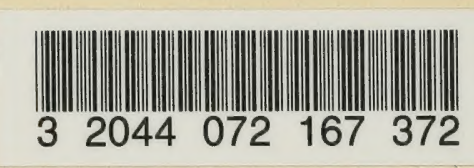


(1)

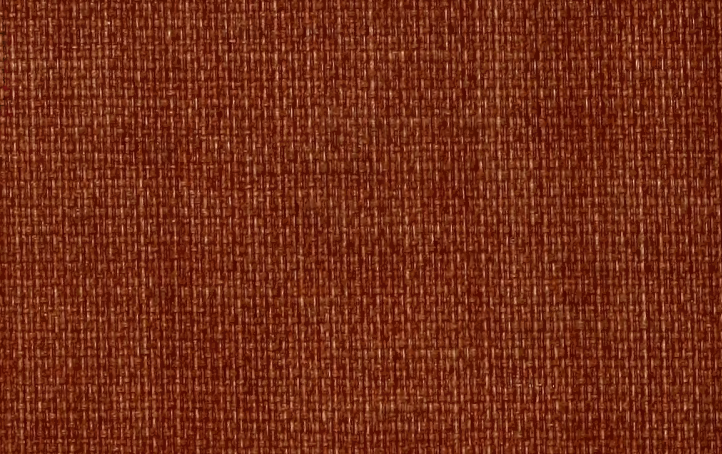

4.

Sho

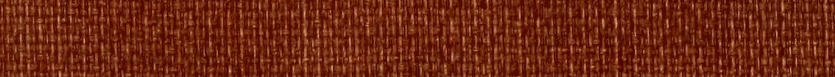

(14)

H.

W.

6.

H.

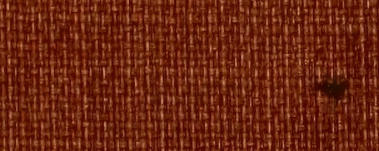

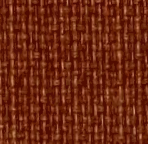

(12) (4)

2.

H.

4.

-2.

5.

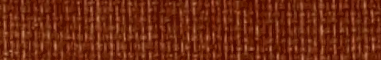

H. 